
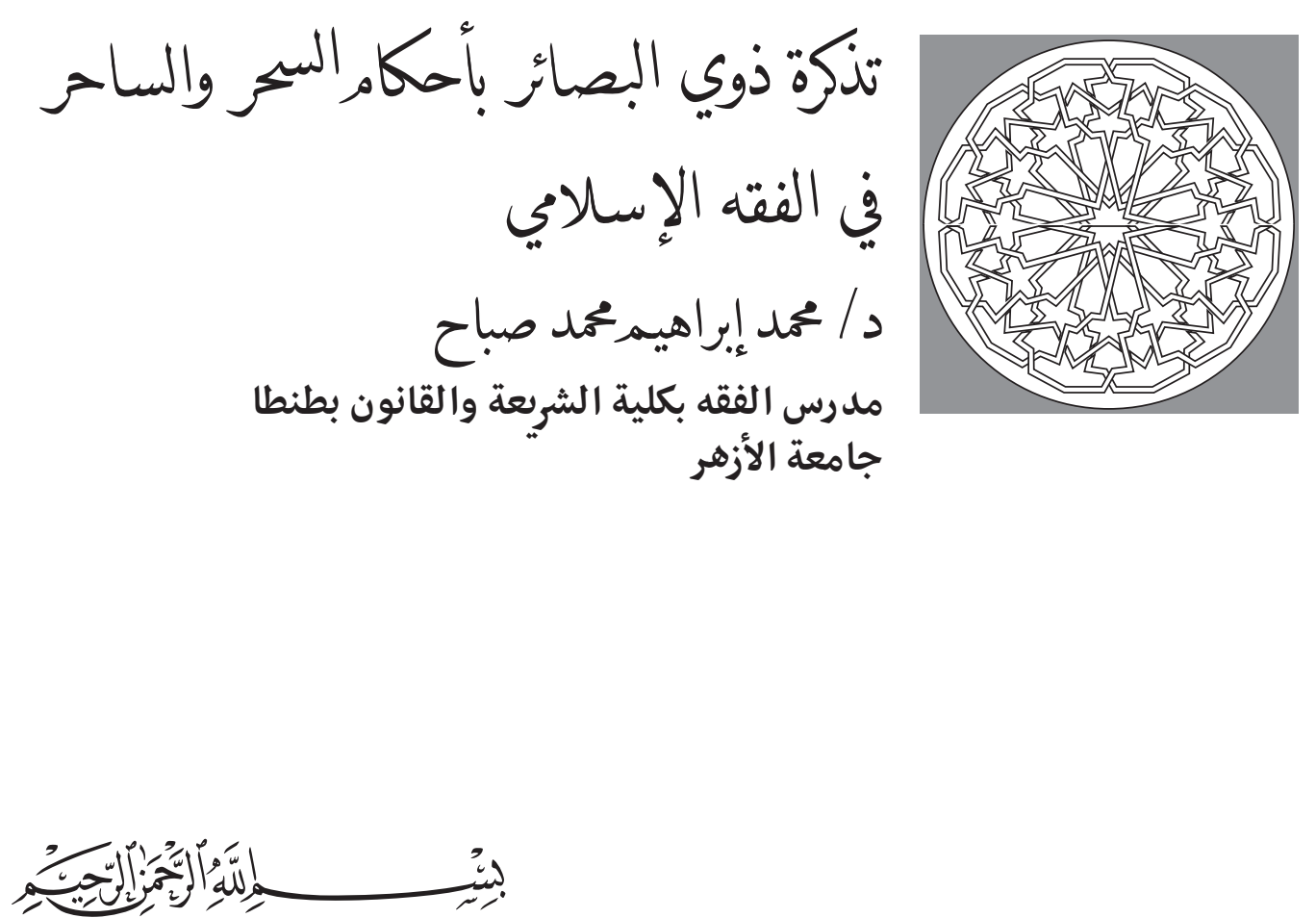

\title{
| المقدمة
}

إن الحمد لله، نحمده ونستـعينه ونستـغفره، ونعوذ بالله تعالى من شرور أنفسنا وسيئات أعمالنا،

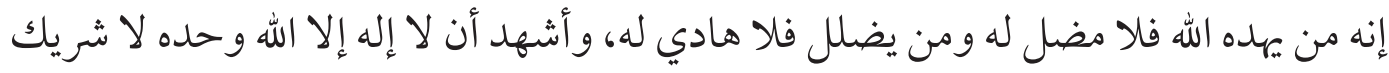

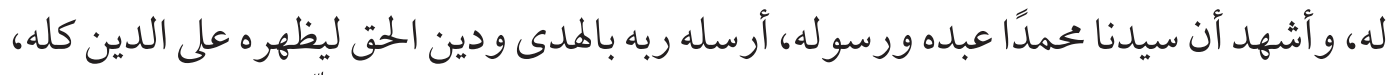

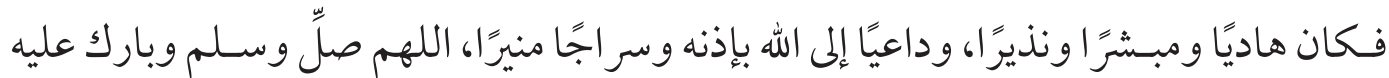

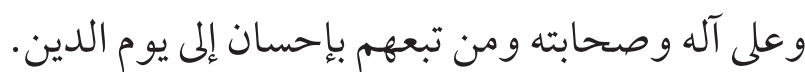

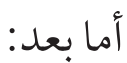
فإنه لا يكاد يخلو عصر و لا زمان من السحرة والمشعو ذين الذين يدَّعون الطب عن طريق الكهانة

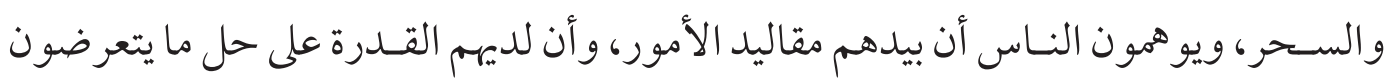

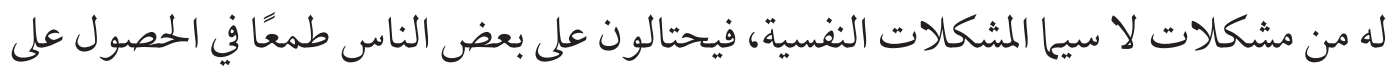

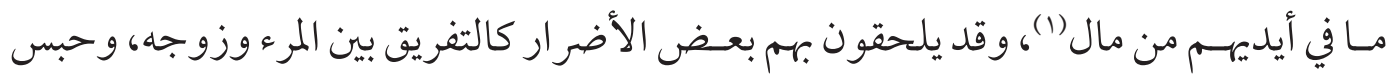

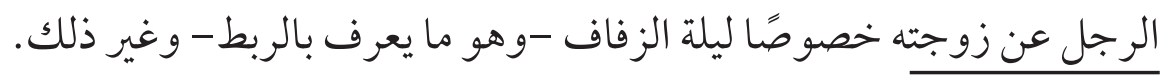

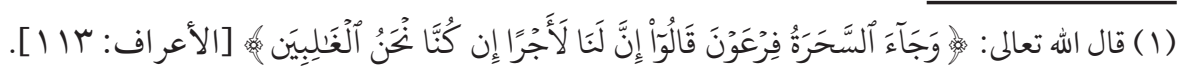


المطلب الثالث: حقيقة السحر.

المطلب الرابع: مدى تأثير السحر في أعيان الأشياء. المطلب الخامس: الفرق بين السحر والمعجزة والكراتئ المرامة. المطلب السادس: الألفاظ ذات الصلة بالسحر ووجه صلته والتها به.

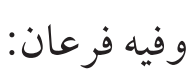
الفرع الأول: التعريف بهذه الألفاظ. الفرع الثاني: وجه صلتها بالسحر.

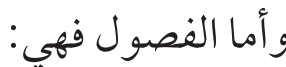
الفصل الأول: الحكم الشرعي للسحر.

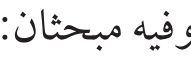

المبحث الأول: الحكم الشرعي لفعل السحر.

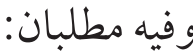

المطلب الأول: الحكم الأصلي لفعل السحر.

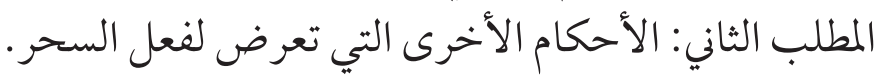
المبحث الثاني: الحكم الشرعي لتعلم السحر وتعليمه. الفصل الثاني: تكفير الساحر. الفصل الثالث: عقوبة الساحر.

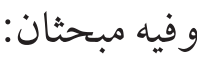
المبحث الأول: عقوبة الساحر المسلم.

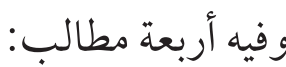
المطلب الأول: معاقبة الساحر المسلم بالقتل. المطلب الثاني: ما يشترط لمعاقبته بالقتل (استتابة الساحر) . المطلب الثالث: ميراث الساحر إذا قتل. المطلب الرابع: تعزير الساحر غير المستحق للقتل.

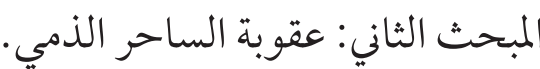
الفصل الرابع: حل السحر عن المسحور (النشرة).

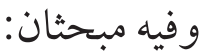
المبحث الأول: حل السحر عن المسحور بالرقية وبعض النشرة

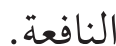

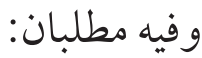
المطلب الأول: حكم حل السحر عن المسحور بالرقية.
علما بأن هؤلاء السـحرة أســو أ النـاس حالا، فهـمـ أفقر الناس

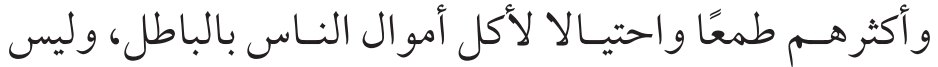

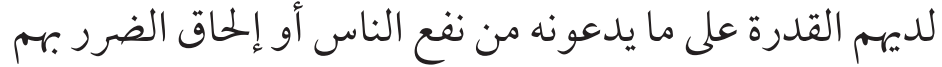

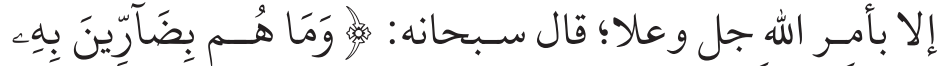

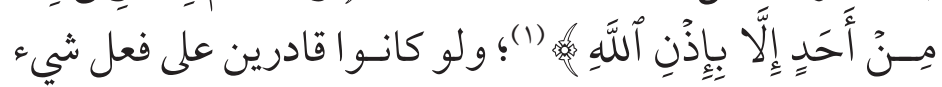

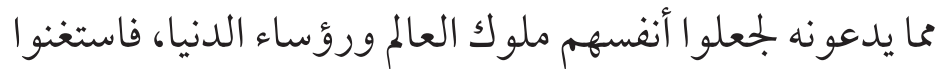

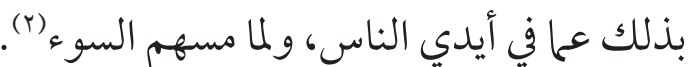

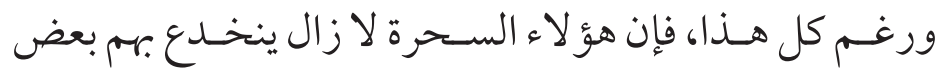

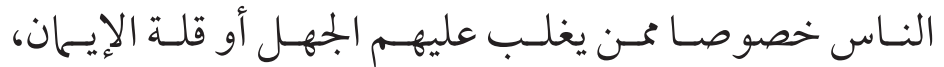

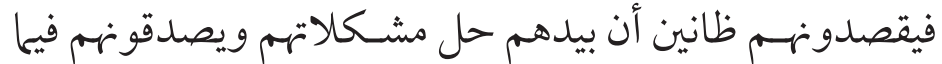

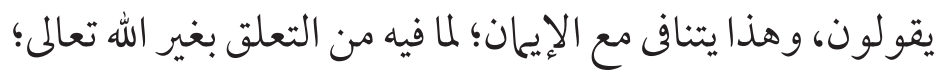

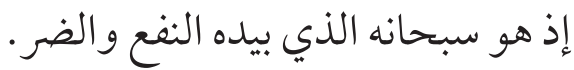

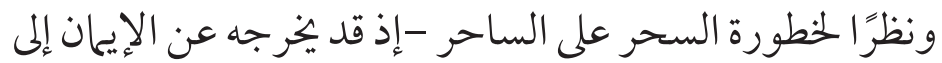

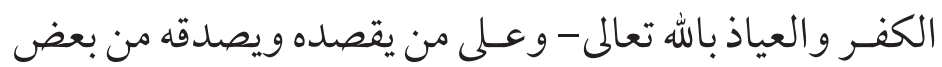

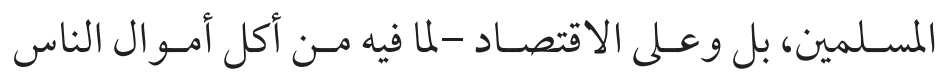

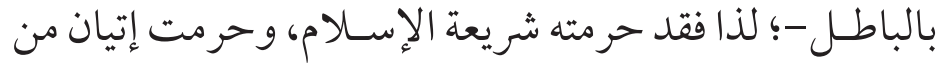

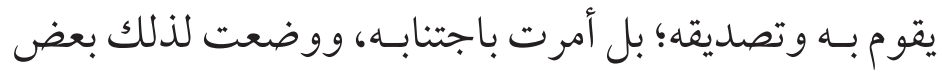

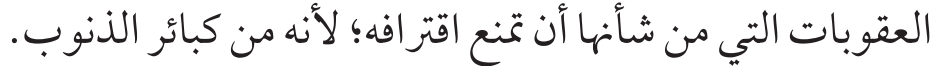

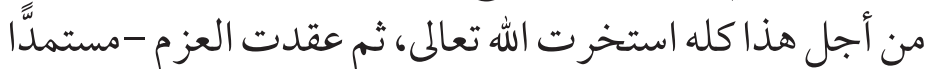

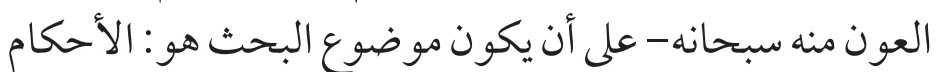
المتعلقة بالسحر والساحر، وسميته:

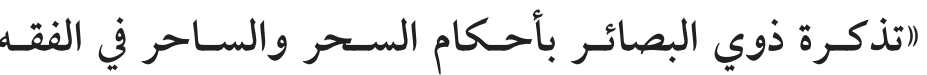

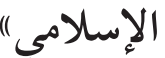
هذا وتشتمل خطة بحثي لهذا المو ضوع على تمهيد، و خمسة فصول

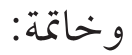
أما التمهيد: فيحتوي على ستة مطالب:

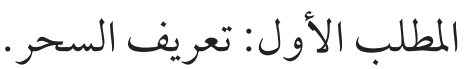
المطلب الثاني: أنواع السحر. تعريف السحر.

(1) سورة البقرة: آية ب (1)

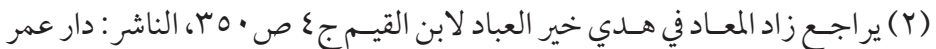

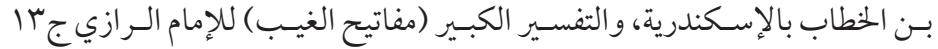

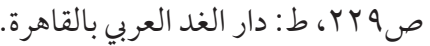




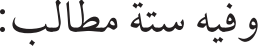

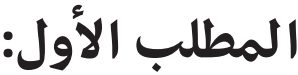 \\ تعريف السحر}

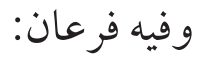

الفرع الأول: السحر في اللغة:

السحر -بكسر السين وسكون الحماء- مشتق من سحرب ومعنداه:

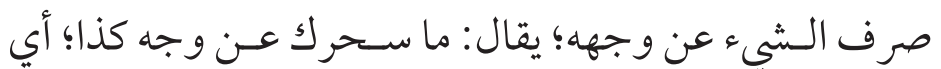

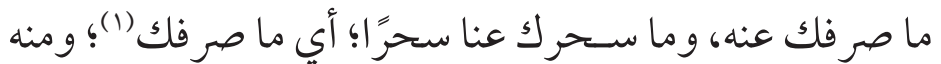

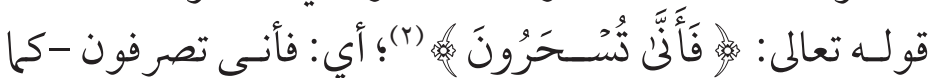

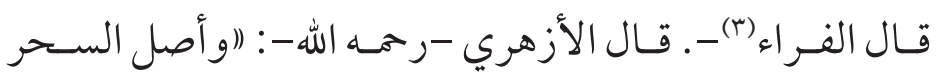

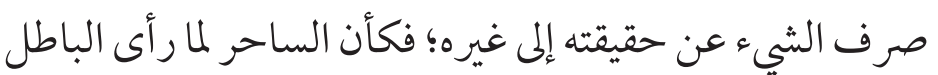

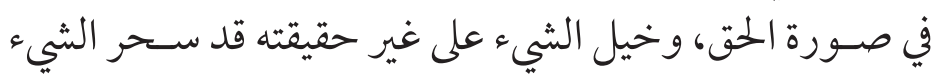

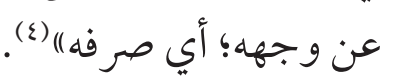

هذا ويطلق السحر في اللغة على عدة معانٍ:

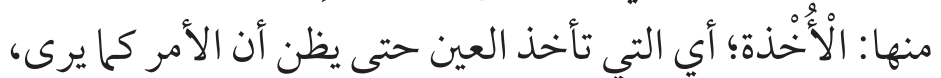

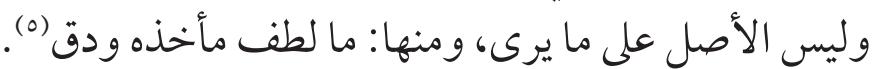

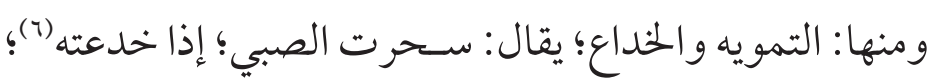

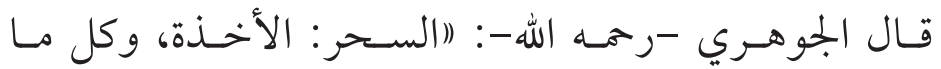

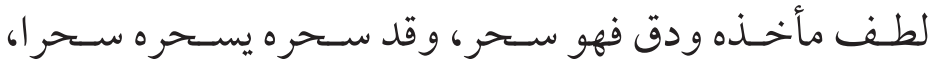

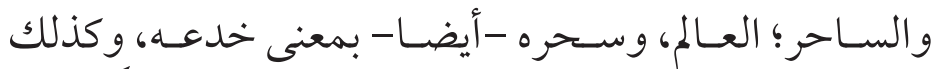

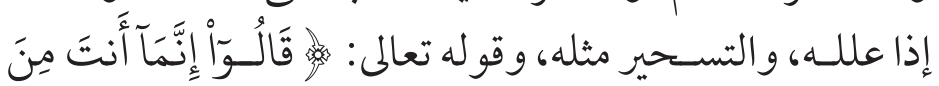

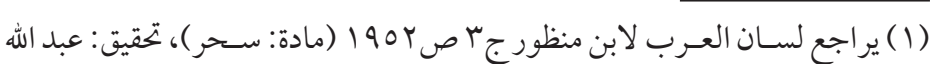

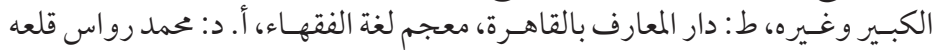

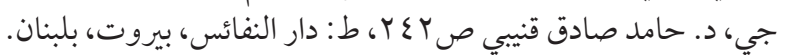
(r) (r) سورة المؤمنون: الآية 19.

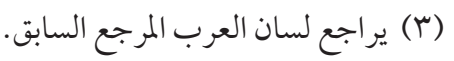

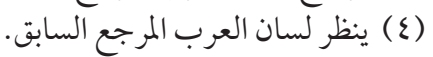

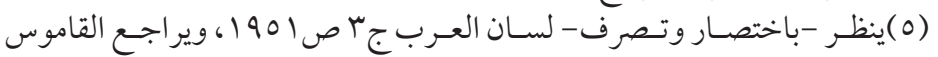

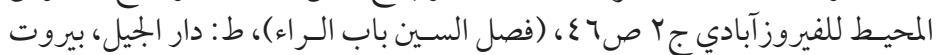

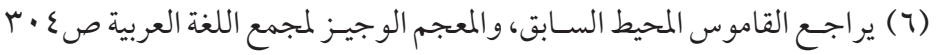
(مادة: سحر)، ط: وزارة التربية والتعليم بالقاهرة.
المطلب الثاني: بعض النشرة النافعة في علاج السحر. المبحث الثاني: حل السحر عن المسحور بسحر مثله. الفصل الخامس: الإجارة على فعل السحر وتعليمه أو حله.

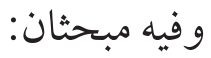
المبحث الأول: الإجارة على فعل السحر وتعليمه.

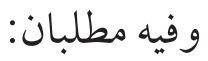
المطلب الأول: حكم الإجارة على فعل السحر.

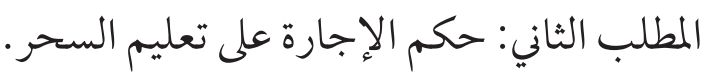

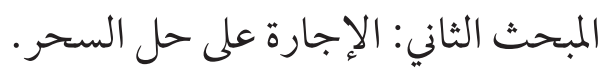

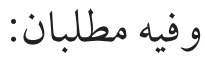

المطلب الأول: حكم الإجارة على حل السحر بالرقية المباحة.

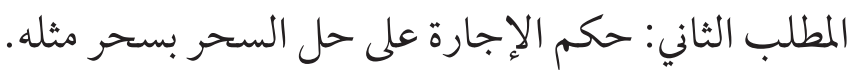

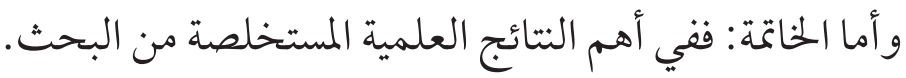

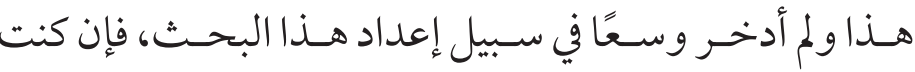

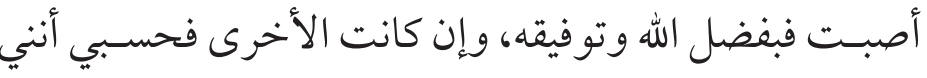

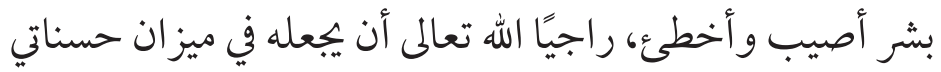

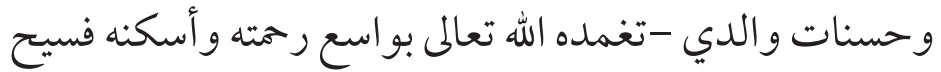
جناته- يوم يسـاق المجرمون إلى جهنم وردًا، ويحشر المتقون إلى

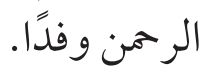
وصلى الله على سيدنا محمد وعلى آله وصحبه وسلم.

د. محمد إبر اهيم صباح

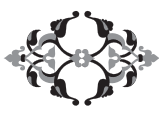


الفرع الثاني: السحر في الاصطلاح:

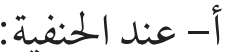

1 - عرفه الجاصصاص -رحمه الله - بأنه كل أمر خَفِيَ سـبيه، وتخيل على غير حقيقته ويجري بجرى التمويه والخداع(·)

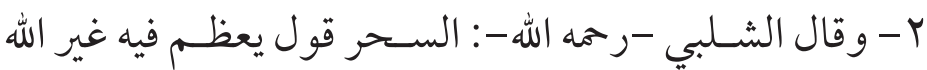
تعالى، وتنسب إليه التقديرات و التأثيرات (11).

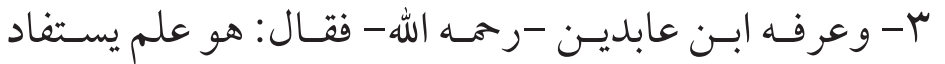

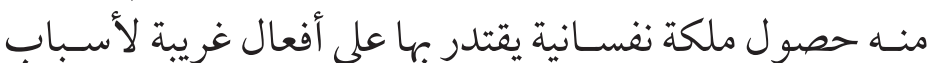

خغية (1) (1)

ب- ب- وعند المالكية:

1 - عرفـه ابن العربي -رحمـهـ الله - بأنه كلام مؤلف يعظم به غير الله، وتنسب إليه الأفعال و المقادير و الكائنات (rا").

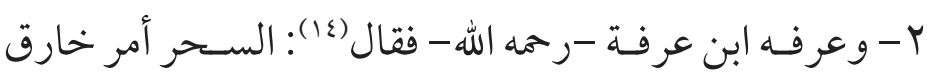
للعادة مسبب عن سبب معتاد كونه عنه (10).

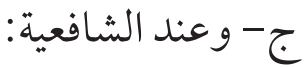
1 - عرفـه الإمـام الرازي -رحمـهـ الله- فقال: السـحر في الشرع

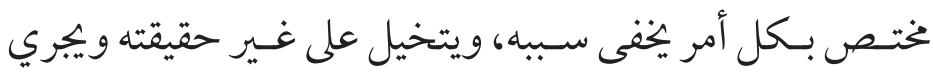

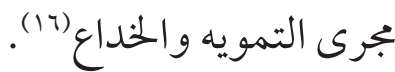

(· (1) ينظر أحكام القر آن للجصاص المرجع السابق.

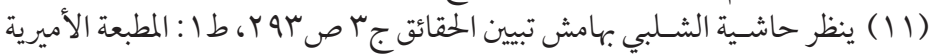

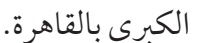

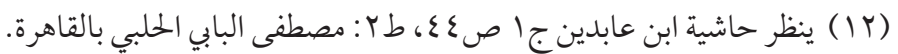

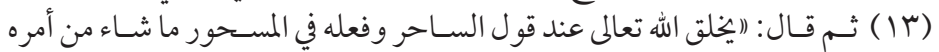

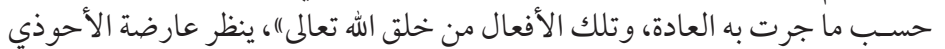

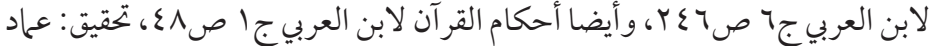
البارودي، ط: المكتبة التوفيقية بالقاهرة.

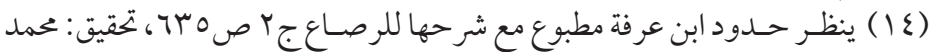

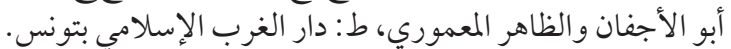

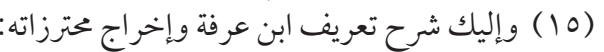

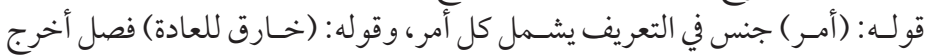

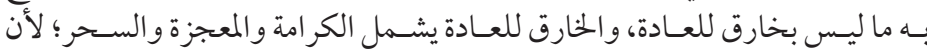

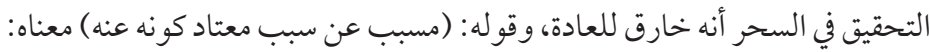

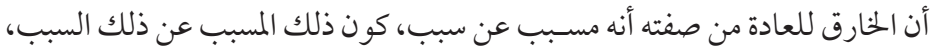

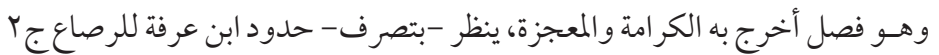

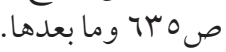

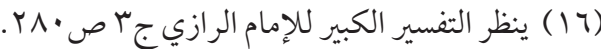

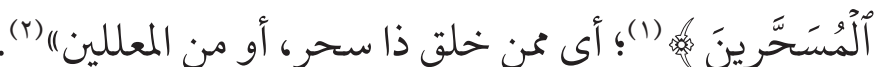

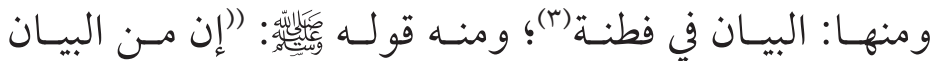

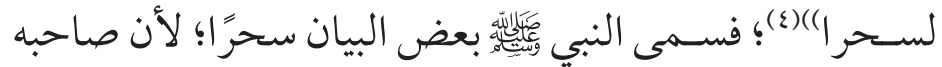
يوضح المشكل ويكشف عن حقيقته بحسن بيانه وبليغ عبارته، فأشبه السحر الذي يستميل القلوب إب (0).

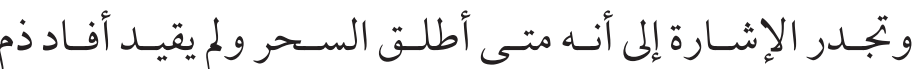

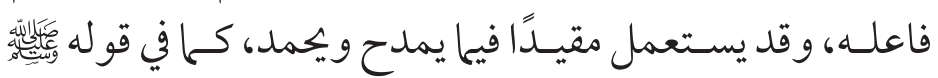
-السابق - ("إن من البيان لسحرًا())(7).

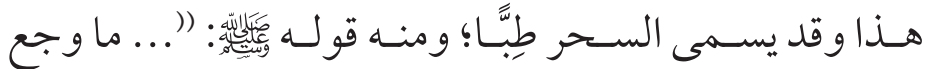

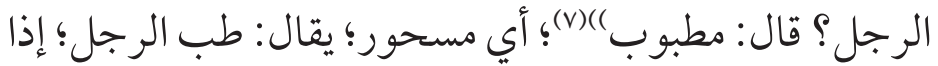

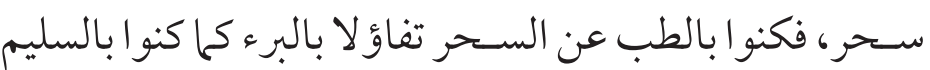

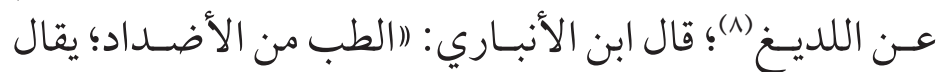

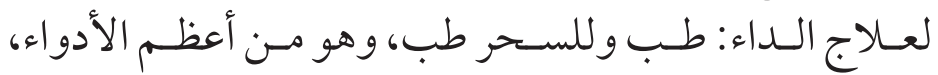
ورجل طبيب حاذق؛ سمي طبيبا لفطنته وحذقه )(9).

(1) سورة الشعراء: الآية سه 101 (1)

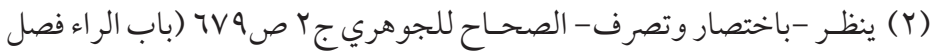
السين) ط: دار العلم للملايين، بيروت البعار بلبنان.

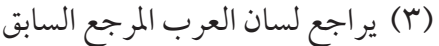

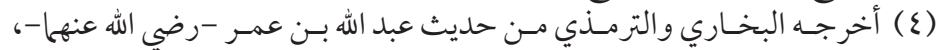

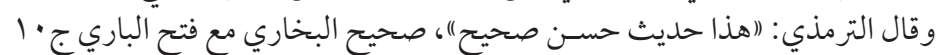

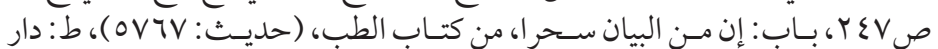

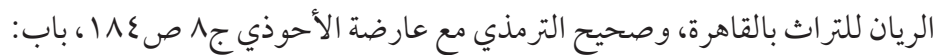

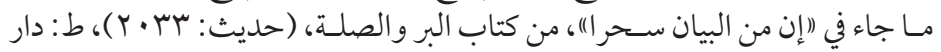
إحياء التراث العربي، بيروت بلبنان البيان.

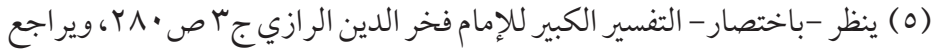

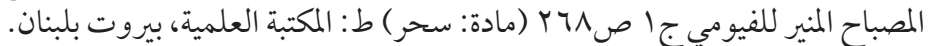

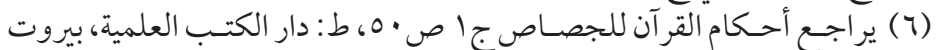

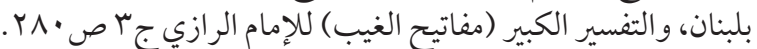

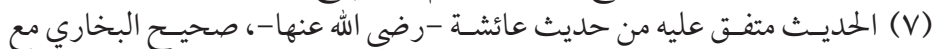

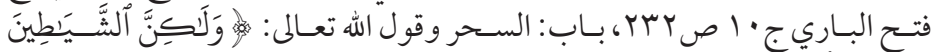

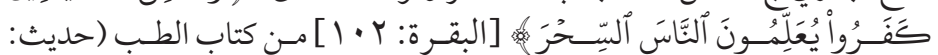

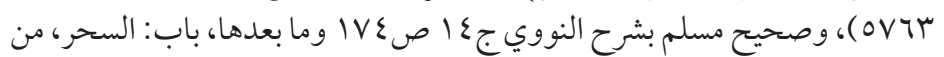

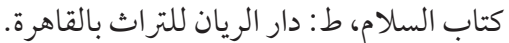

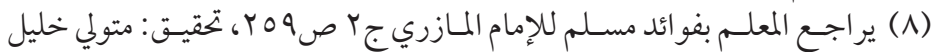

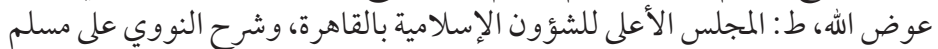

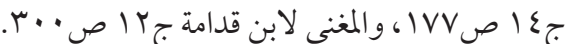
(9) ينظر المعلم للإمام المازري المرجع السابق. 


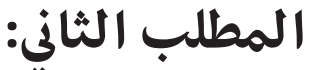 \\ أنواع السحر (أقسامه)}

ذكـر الإمام الجحصـاص من الحنفية والرازي من الشـافعية أنواع السحر، وإليك أهمها باييجاز:

\section{النوع الأول: سحر أهل بابل:}

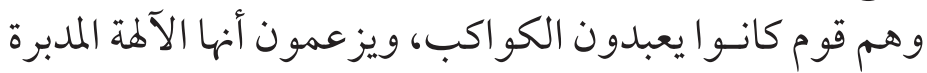

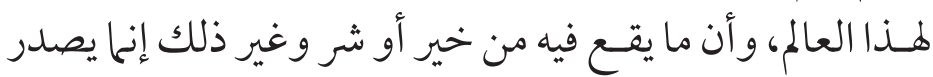

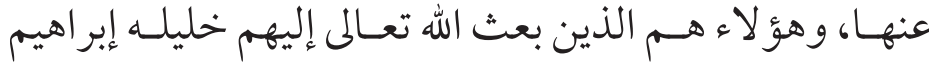

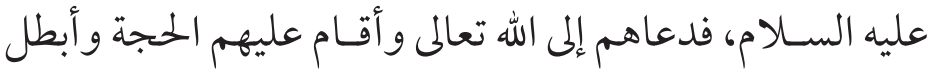

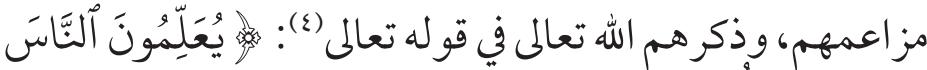

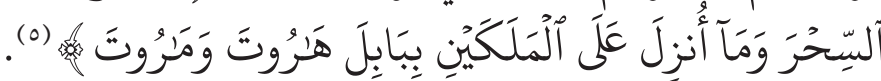

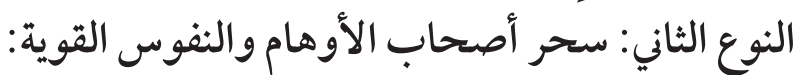

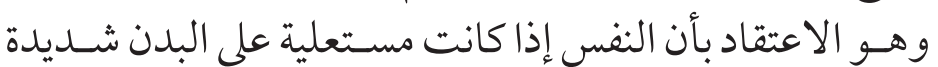

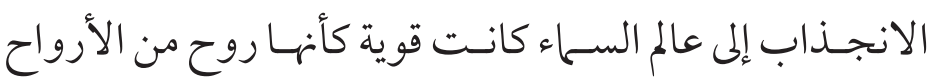

السماوية ولها التأثير في مو اد هذا العالم (7).

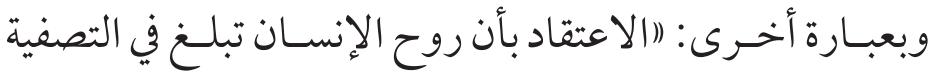
والقـوة إلى حيث يقدر بها على إيياد الأجسـام و الحيـاة والقدرة الأنسان

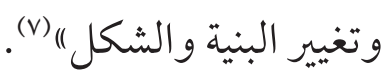

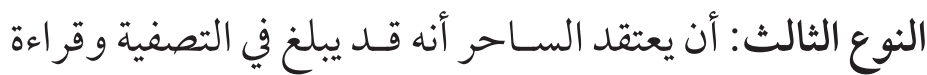

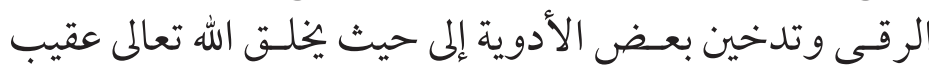

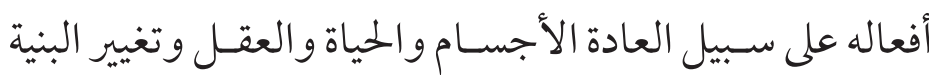

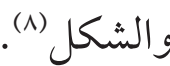

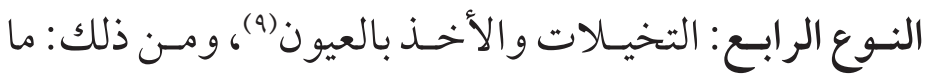

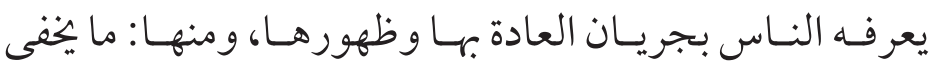

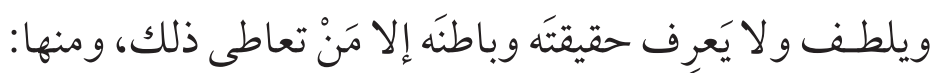

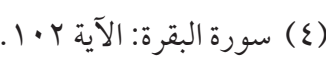

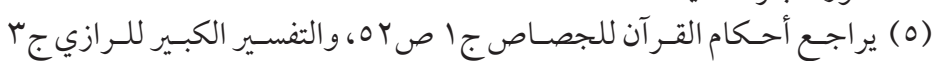

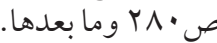

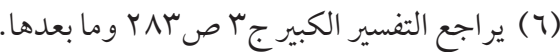

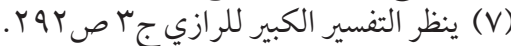

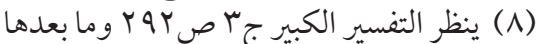

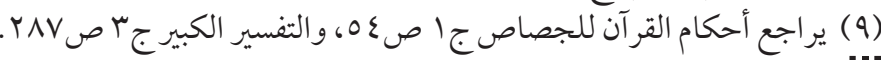

r - على حين عرفه الخطيب -رحمه الله - فقال (1): مز اولة النفوس الخبيثة لأفعال وأقوال يترتب عليها أمور خارقة للعادة(r). د- وعند الحنابلة:

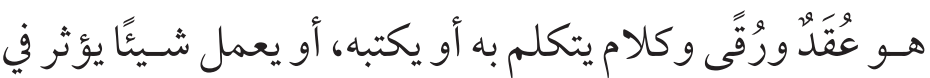

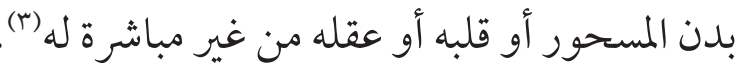
ويمكن مناقشة هذه التعريفات بالآتي: أو لا: بأنها غير جامعة كما هو ملاحظة النعات على النحو النحو التالي:

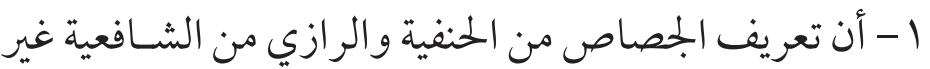

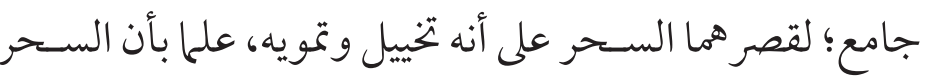

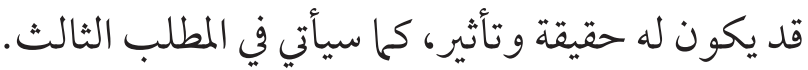

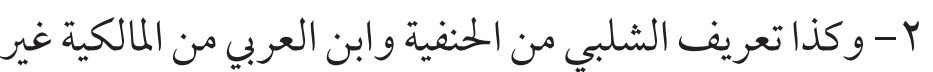

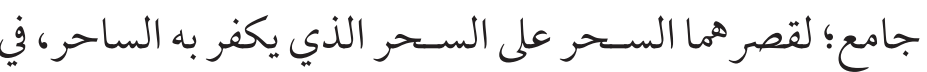

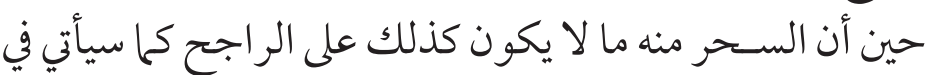

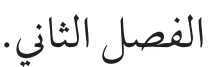

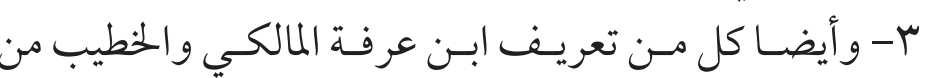

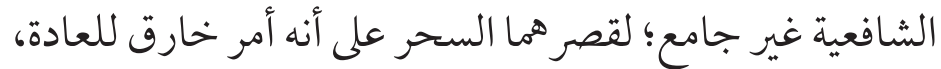
والسحر قد لا يكون خارقًا للعادة.

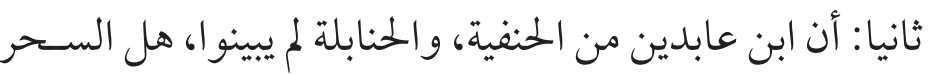
خارق للعادة أم لا؟ تلابن

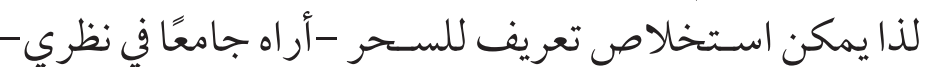

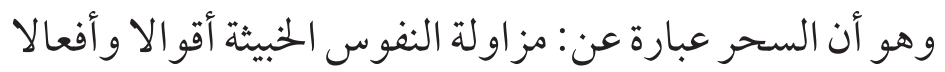

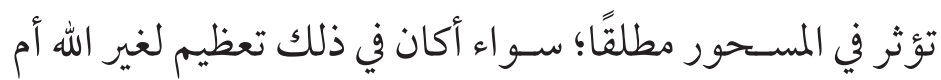

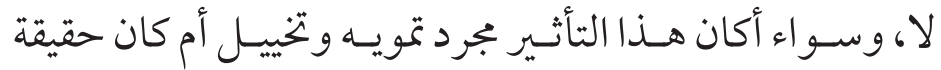

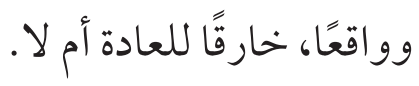

(1) ينظر مغني المحتاج للخطيب ج) ص. - 1 ا، ط: دار الفكر، بيروت بلبنان.

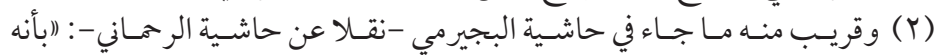

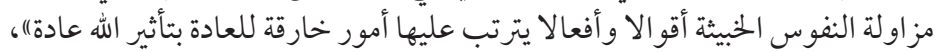

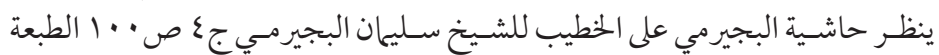
الأخيرة، مصطفى البابي الحلبي وأولاده بالقاهرة.

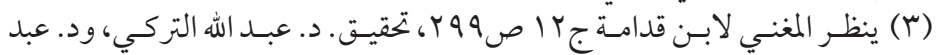

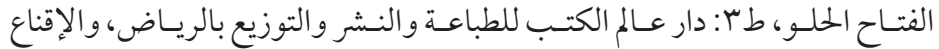

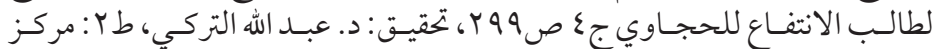
البحوث والدراسات الإنسامية والعربية بدار هجر، توزيع وزارة الشؤون الإسلامية

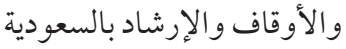


وإليه ذهب جمهور أهل السنة(() (جمهور الحنفية()"، والمالكية(1)،

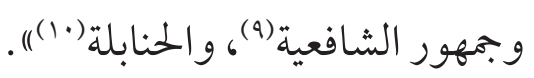

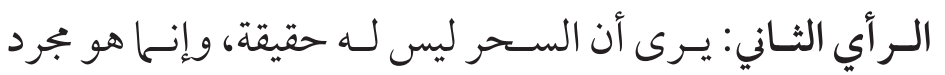

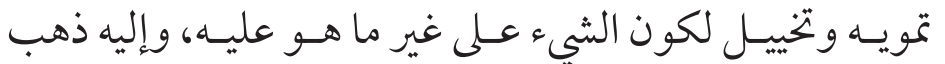

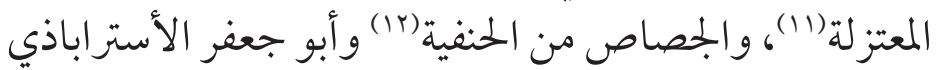

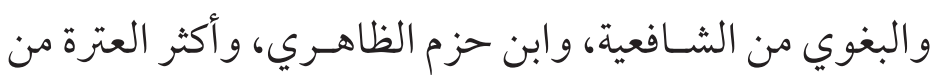

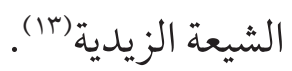

الأدلة ومناقشتها:

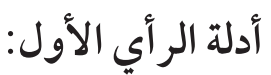
استدل الجمهور على أن السحر له حقيقة بالقر آن الكريم والسنة والإجماع والمعقول:

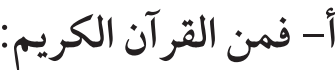

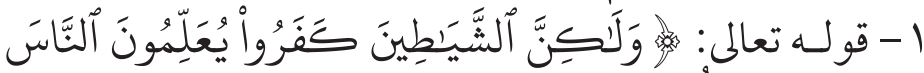

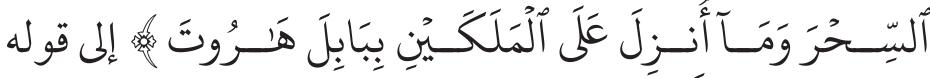

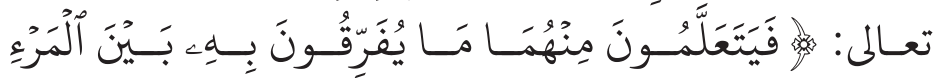

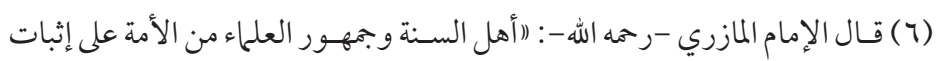

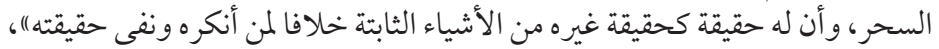

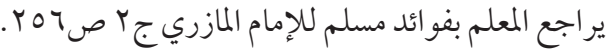

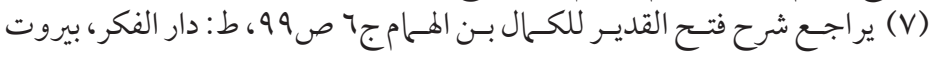

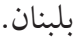

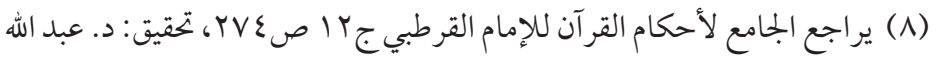

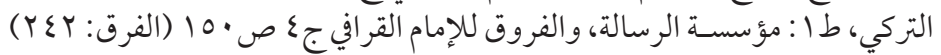

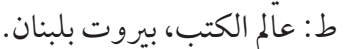

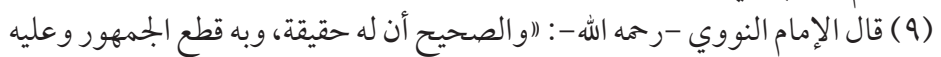

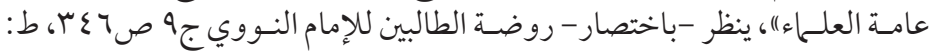

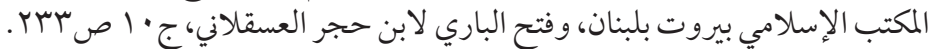

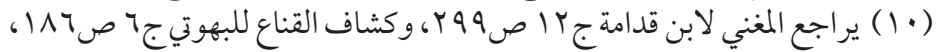

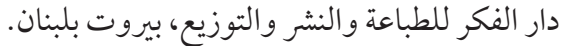

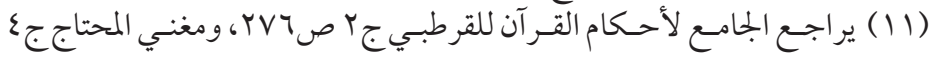

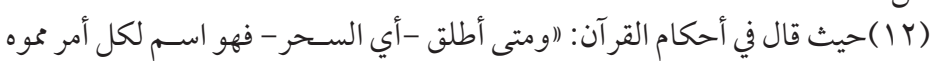

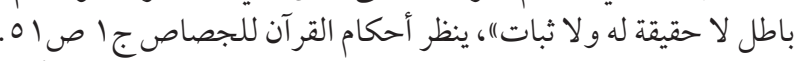

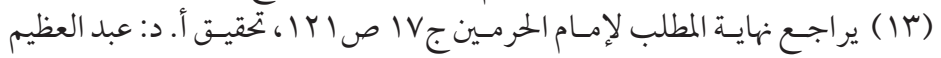

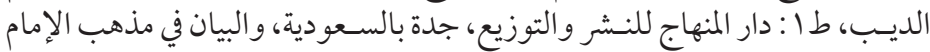

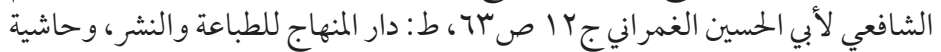

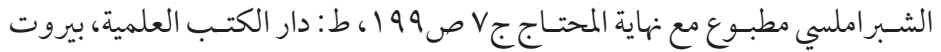

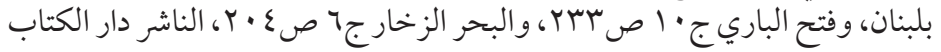

ما يلطف فلا يعرفه إلا من تعاطاه وتأمله؛ كخيط السحار الذي يخرج مرة أحر، ومرة أصفر، ومرة أسود (1).

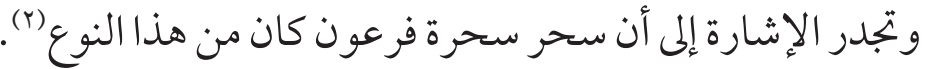

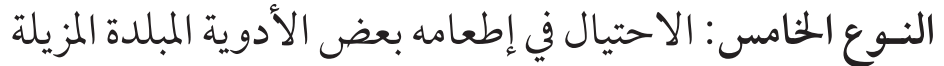

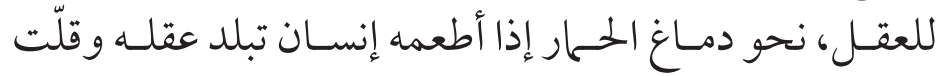

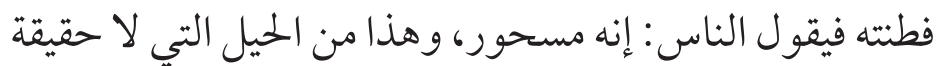

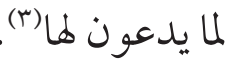

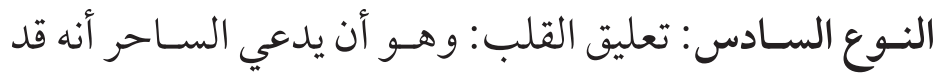

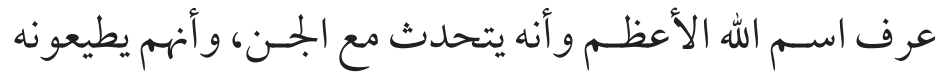

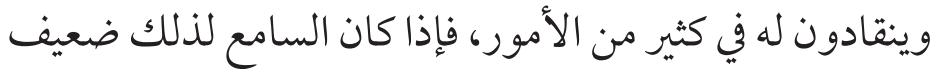

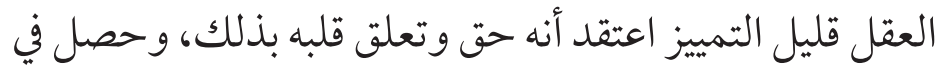

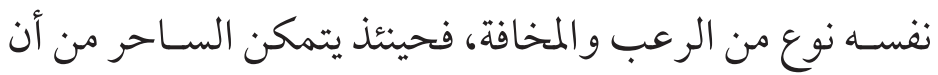

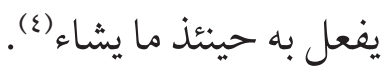

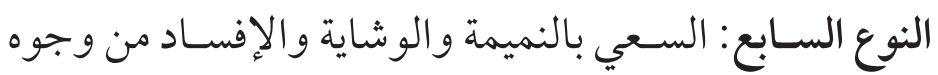
خفية لطيفة، وذلك عام شائع في كثير من الناس بـ (0).

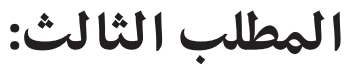

\section{حقيقة السحر}

هل السـحر له حقيقـة وتأثير في أعيان الأشـياء أم أنه مجرد تمويه وتخييل؟ هن الن اختلف الفقهاء في ذلك على رأيين: الر أي الأول: يرى أن السـحر حق وله حقيقة وتأثير في الأعيان، رئ

(1) ومـن لطيف ذلك: ما يفعله المشـعوذون من جهـة الحر كات وإظهار التخيلات

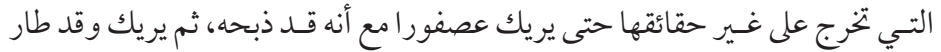

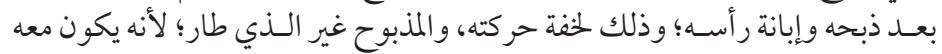

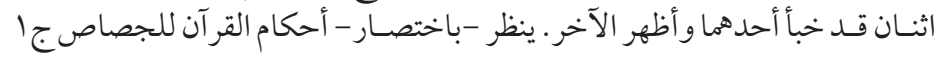

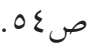

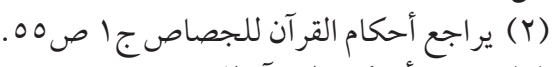

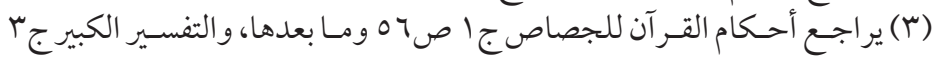

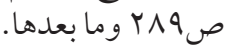

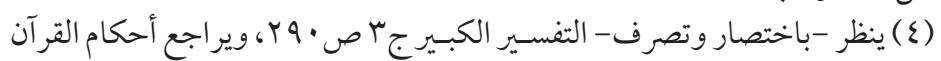

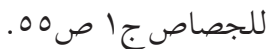
(0) ينظر -باختصار - أحكام القر آن للجصاص جا صحه 0، والتفسير الكبير المرجع السابق. 
قال: في مشـط ومشاطة (V)، قال: وأين؟ قال: في جف طلعة ذكر

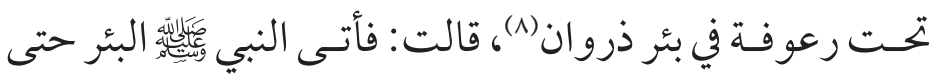

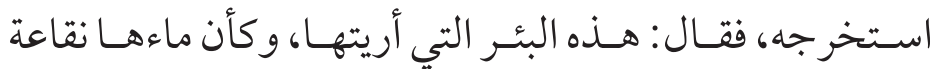

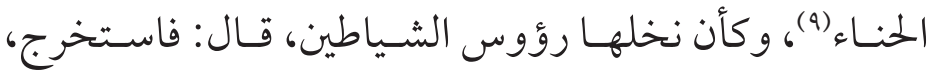
قالت: فقلت: أفلا تنشرت؟ فقال نال: أما الله فقد شفاني، وأكره أن أن

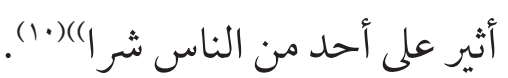

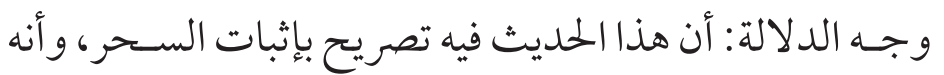
أشياء دفنت، و أخرجت، وهذا لا يكون إلا فيها له حقيقة (11).

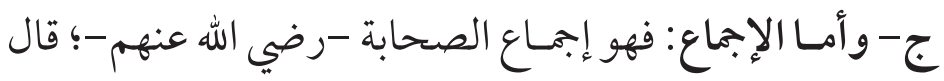

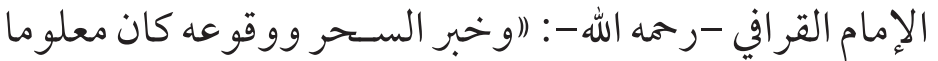

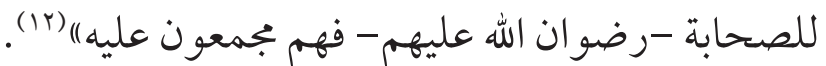

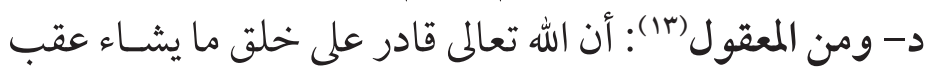

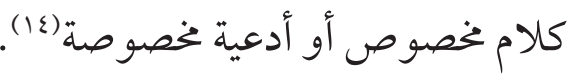

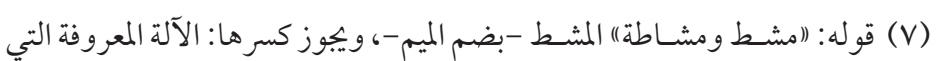

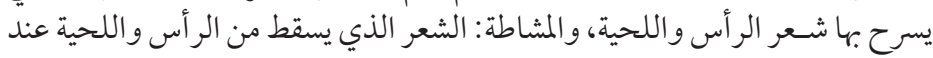

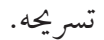

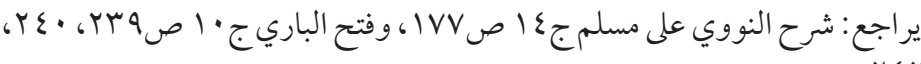

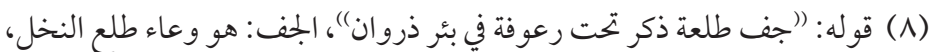

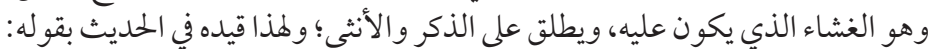

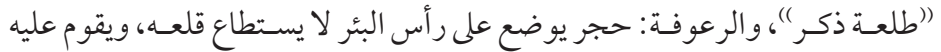

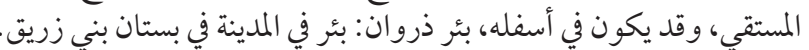

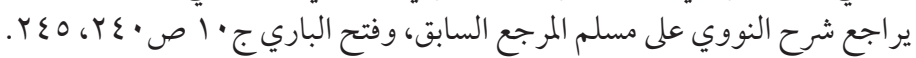

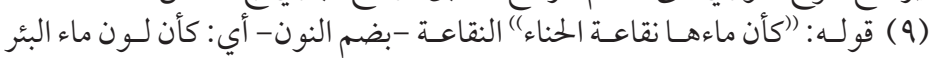

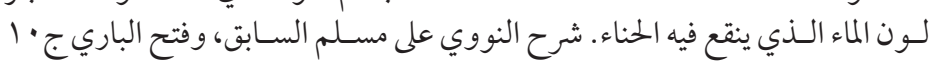

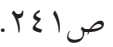

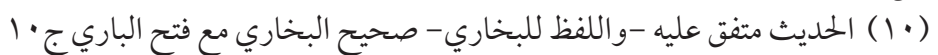

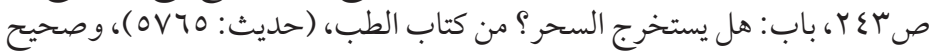

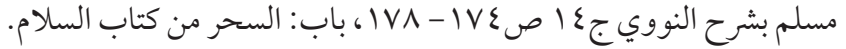

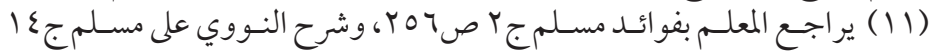

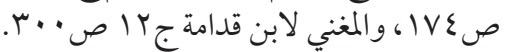

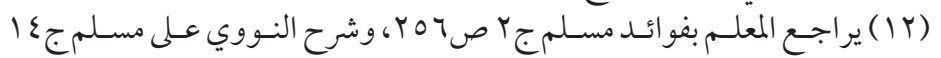

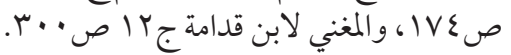

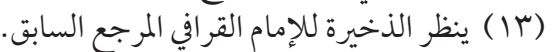

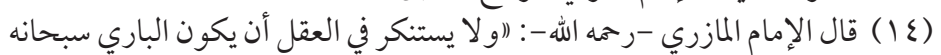

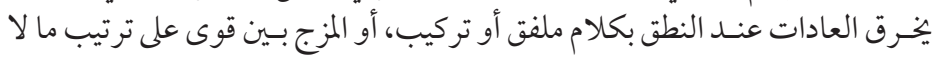

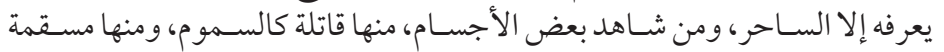

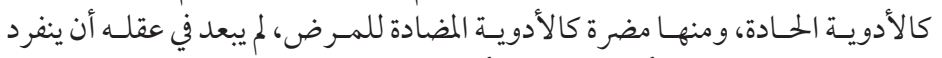

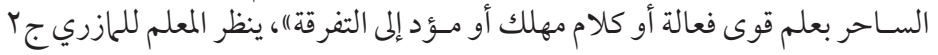

وَزَوْجَهِ

وجه الدلالة: أن هذه الآية الكريمة تدل على أن للسـحر حقيقة من جهتين:

الأولى: أنهـا ذكــــت السـحر وتعليمه، ولـو لم يكن لـه حقيقة لم

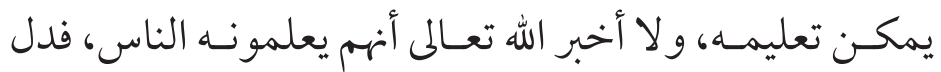
ذلك على أن له حقيقة (r). الثانيـة: أن الله تعالى جعلهم كفــار ابتعليمه، فثبت أنبـ أن له حقيقة؛ إذ لو لم يكن للسحر حقيقة لما جعلهم الله تعالى كفار ابذلك (r).

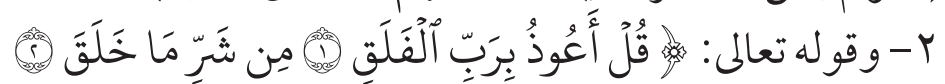

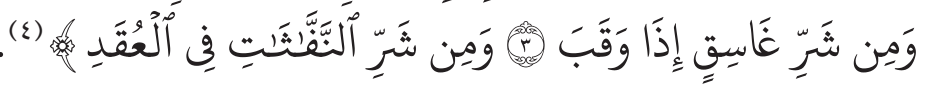

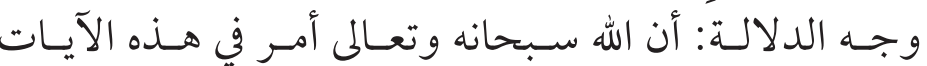

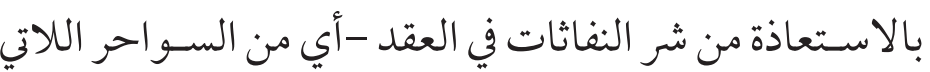

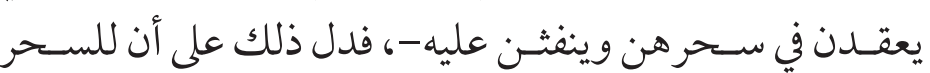

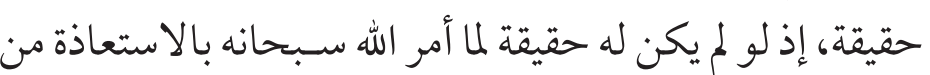
شره

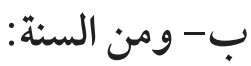
مـا روي عن سـفيان بن عيينة عن هشـام بن عـروة عن أبيه عن فئن

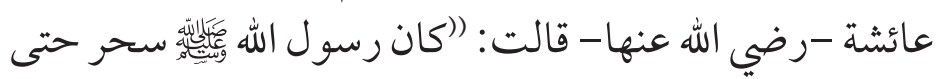

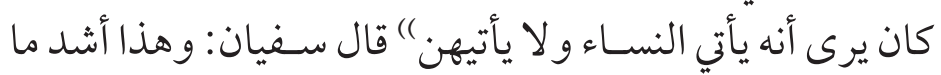

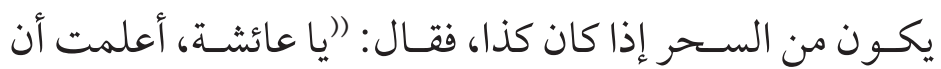

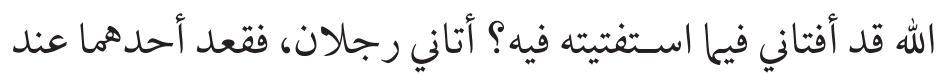

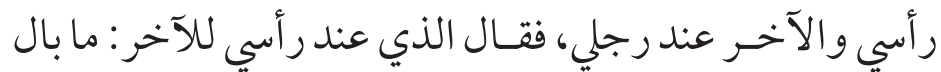
الرجل؟ قـال: مطبوب؟ (ج)، قال: ومن طبه؟ قال: لبيد بن أعصى

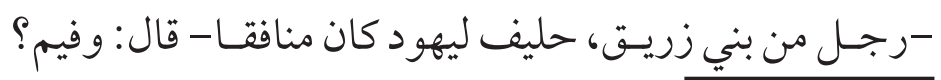

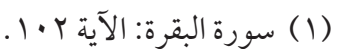

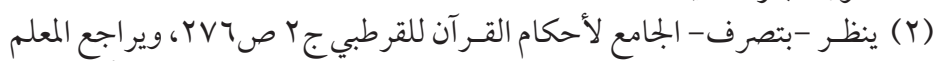

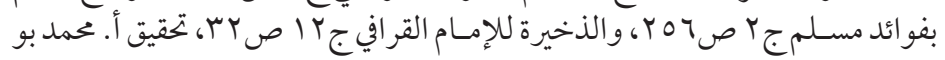

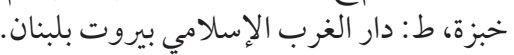

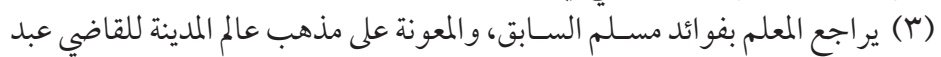

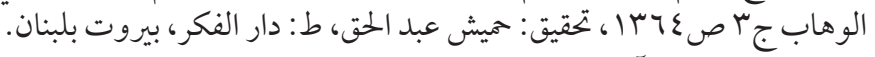

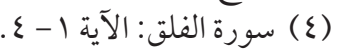

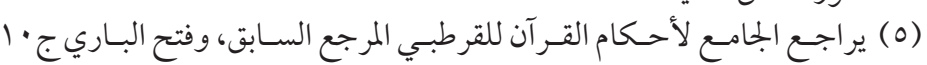

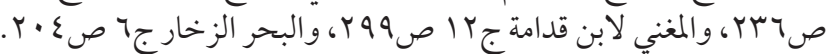

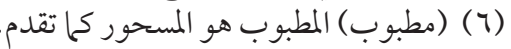




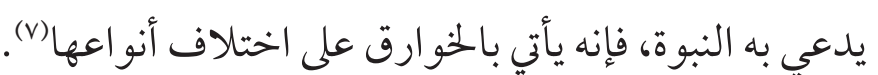

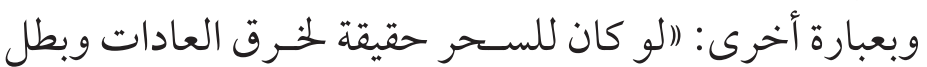

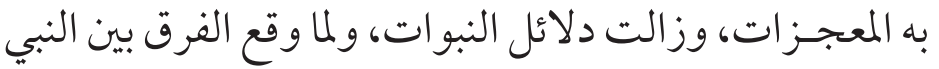

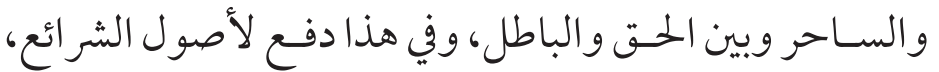

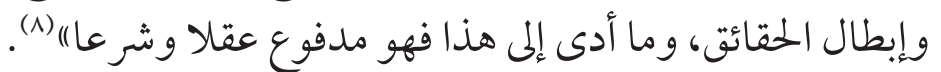

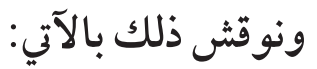
1 - بأنه لا يلزم من القول بأن للسـحر حقيقةً إبطالُ المعجزات؛

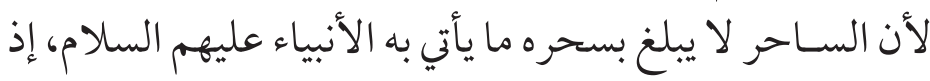

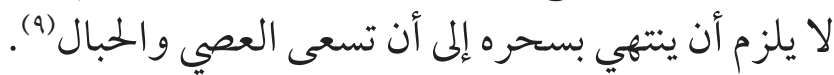

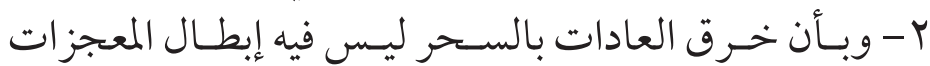

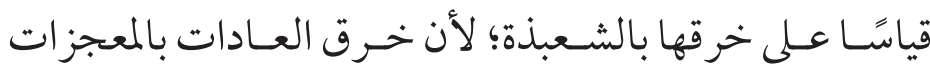

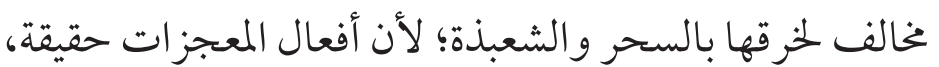
وأفعال السحرة مستحيلة(·).

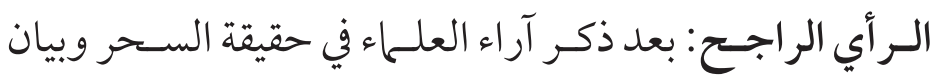

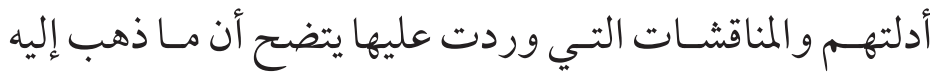

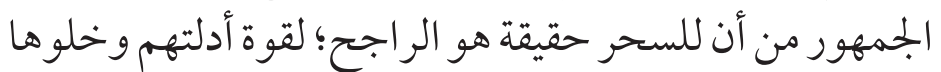
عن المعارض(11). ثمرة الخلاف: تبدو ثمرة الخلاف في الآتي:

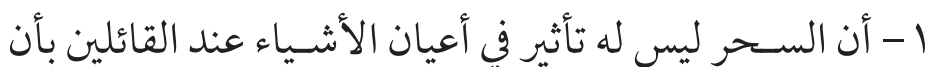
السحر مجرد تخييل، وليس له حقيقة.

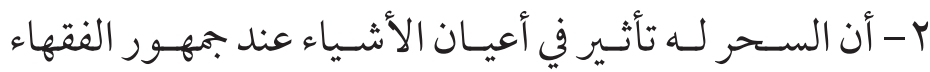

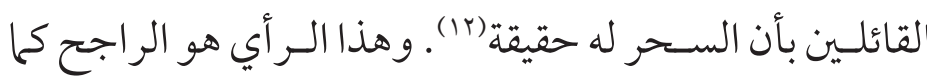

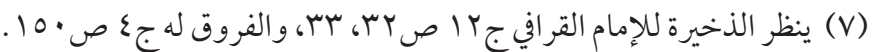

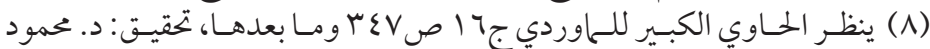

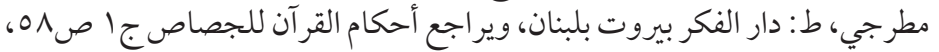

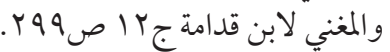

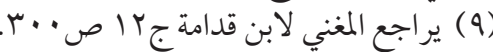

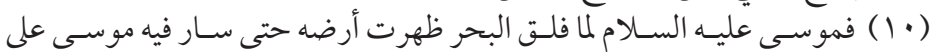

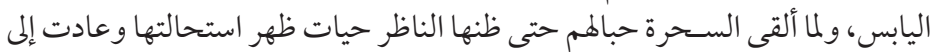

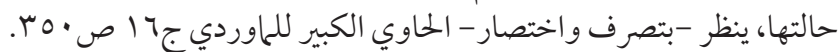

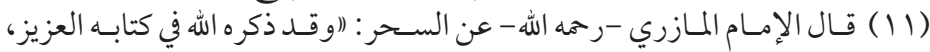

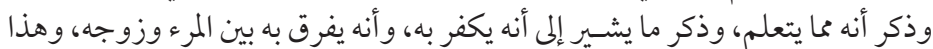

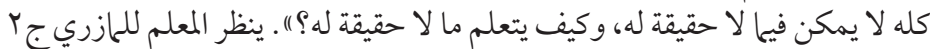

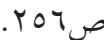

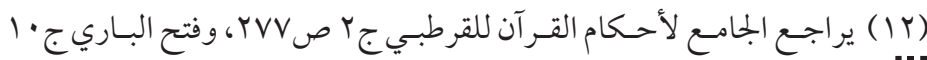

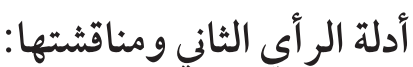
استـدل أصحاب الر أي الثاني على ما ذهبوا إليه بالقرآن الكريم

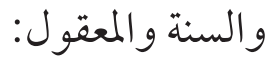

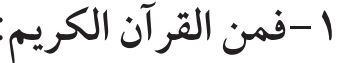

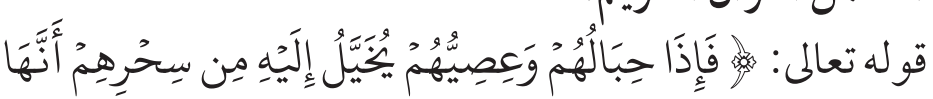

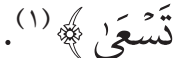
وجه الدلالة: أن هذه الآية تدل بمنطوقها على أن السـحر تخييل

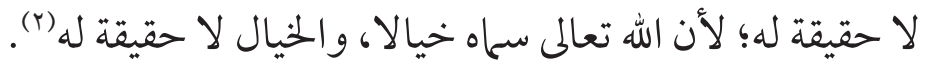

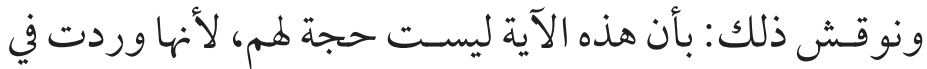

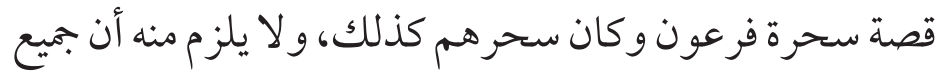
السحر تخييل (r).

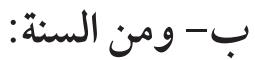

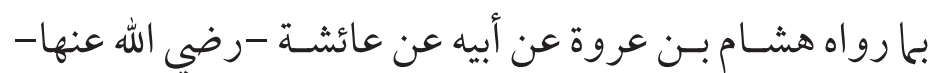

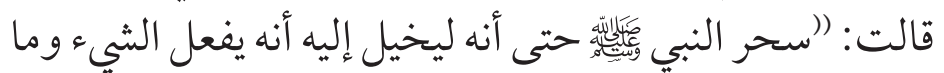

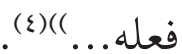

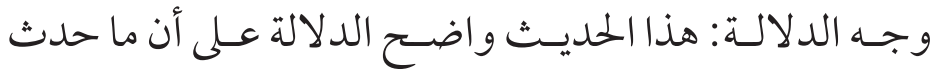

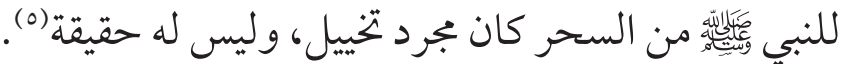

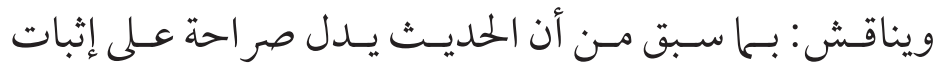

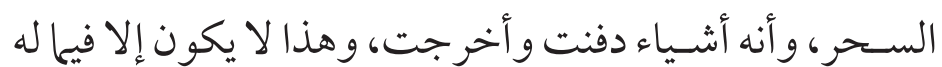
حقيقة (T). ج- ومن المعقول: أنه لو كان للسـحر حقيقة لأمكن الساحر أن (1) - (1) سورة طه: الآية 77.

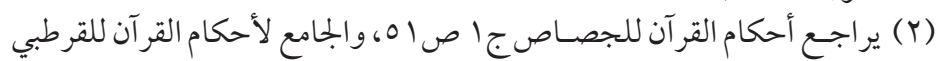

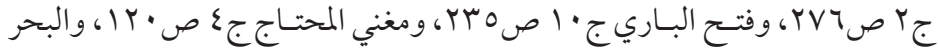

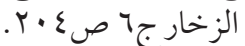

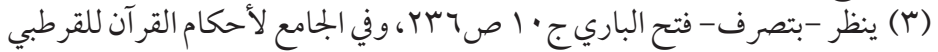
- المرجع السابق-: (لا حجة فيه؛ لأننا لا ننكر أن يكون التخييل وغيره من جملة السحر ).

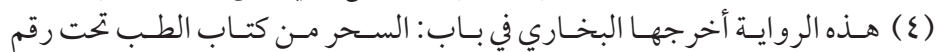

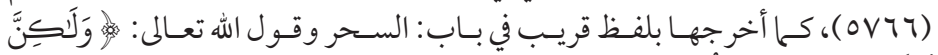

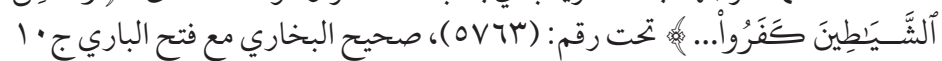

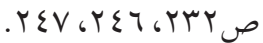

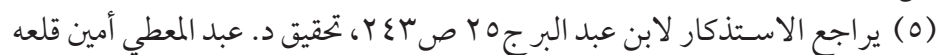

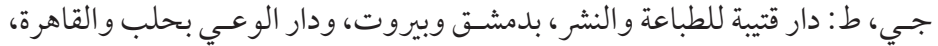
توزيع مؤسسة الرسالة.

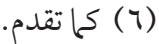


في مقام التهويل، ولو جاز أن يقع بالسـحر أكثر من ذلك لذكره الله تعالى (0). ونوقشش ذلك: بـأن ذكر التفرقة بين الزوجـين في الآية الكريمة

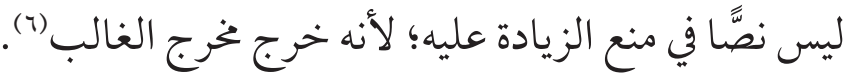

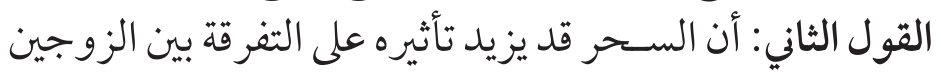

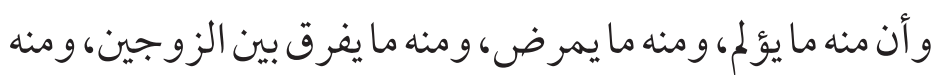

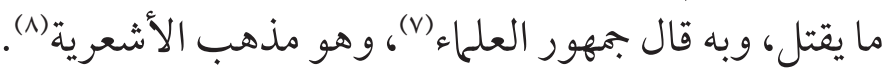

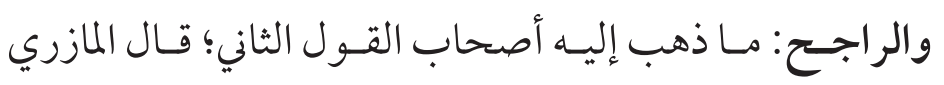

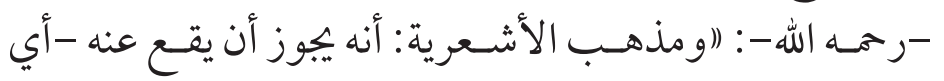

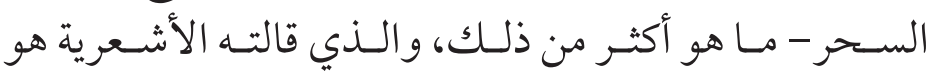

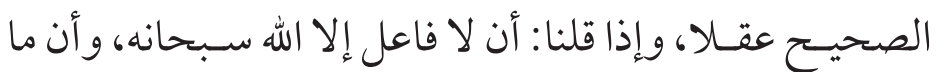

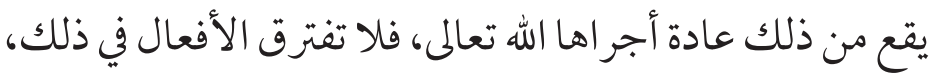

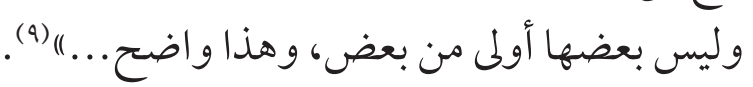

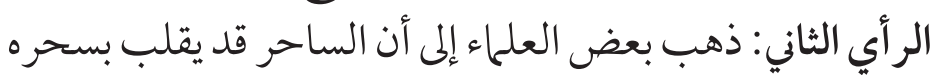

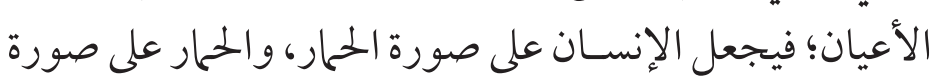

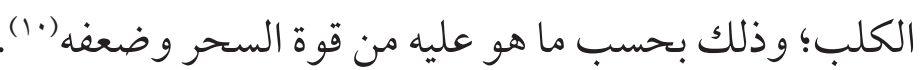

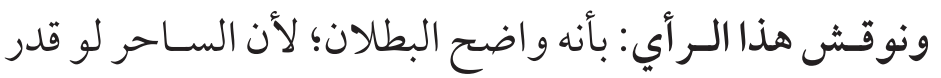

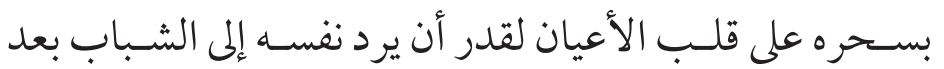

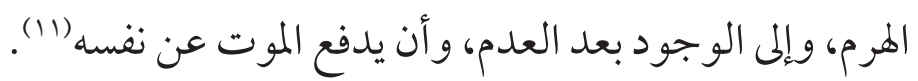

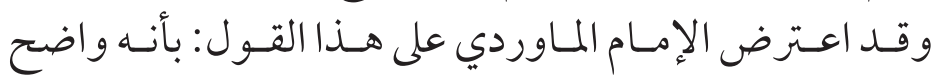

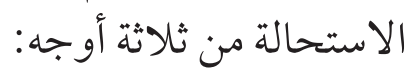

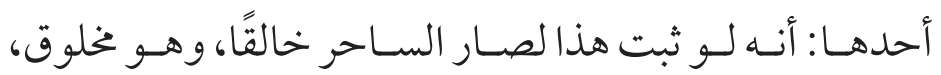

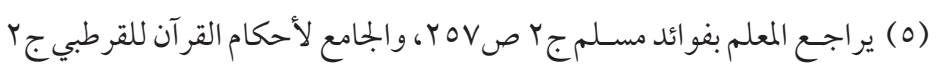

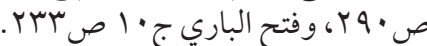

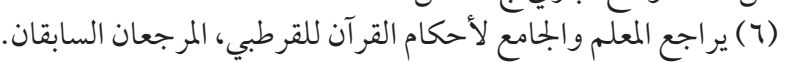

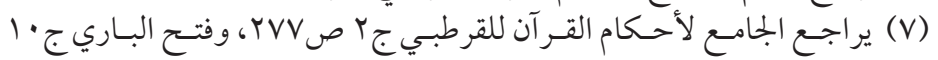

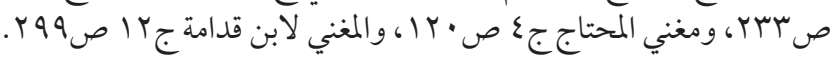

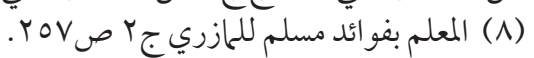

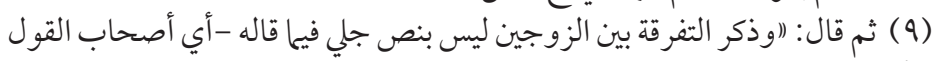

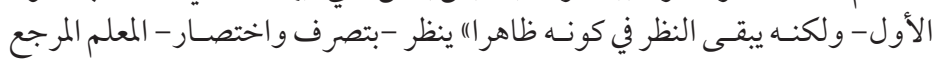
السابق.

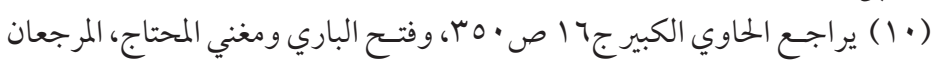

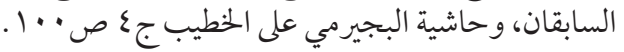

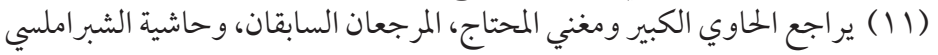

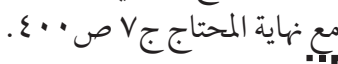

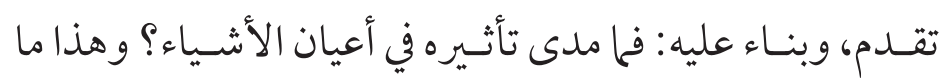
أتناوله بمشيئة الله تعالى في المطلب فل الرابع.

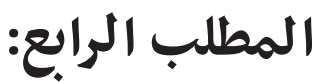 \\ مدى تأثير السحر في أعيان الأشياء}

تمهيد: اتفق الفقهاء القائلون بأن للستحر حقيقة وتأثيرًا في أعيان

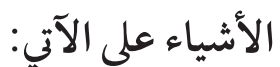
1 - أنه قد يظهر على يد الساحر خرق العادات ماليس في مقدور

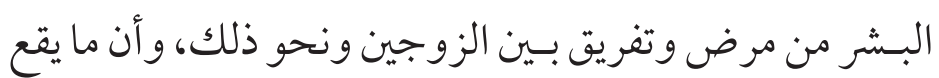

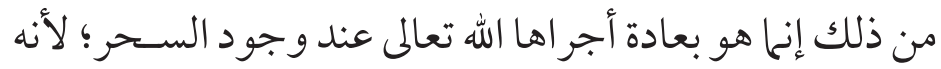

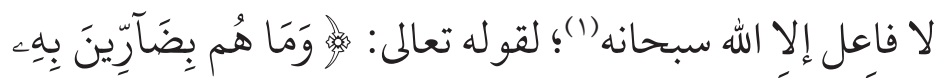

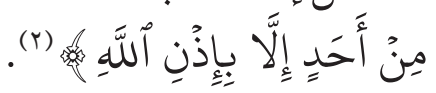

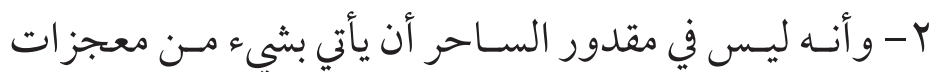

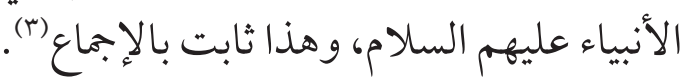

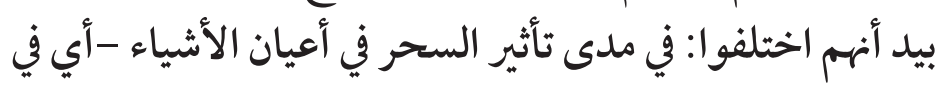
القدر الذي يقع عن السحر - على رأيين:

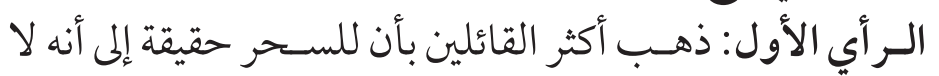

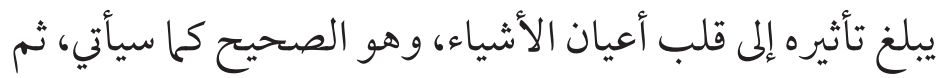
إن أصحاب هذا الر أي اختلفوا في القدان الأنياهر وهو الذي يقع عن السحر

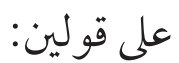
القول الأول: أن السـحر لا يزيد تأثيره على التفرقة بين الزوجين وبه قال بعضهم.

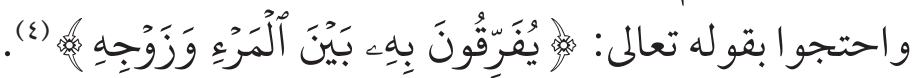

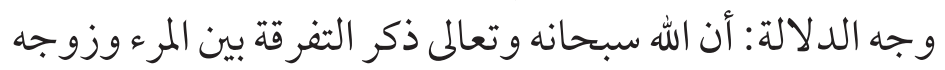

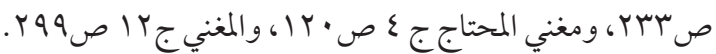

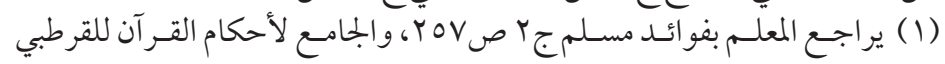
السابق.

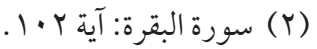

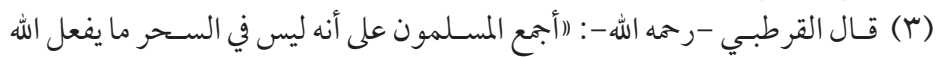

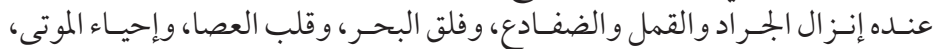

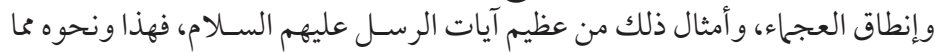

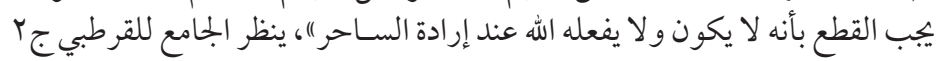
ص صA

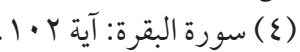


الفرع الأول: وجه الاتفاق بينها: تتفق الكرامة مع المعجزة في أن كلا منهها أمر خارق للعادة -كما

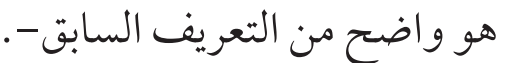

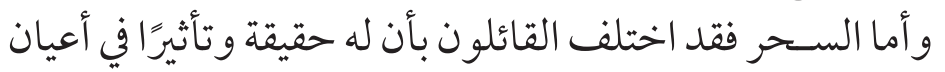
الأشياء في خرقه للعادة على قولين:

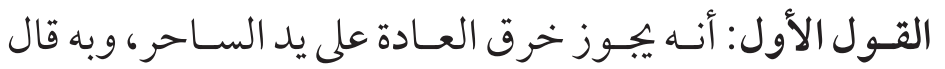

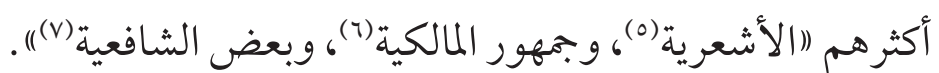

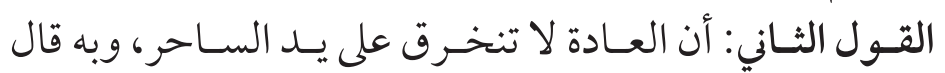

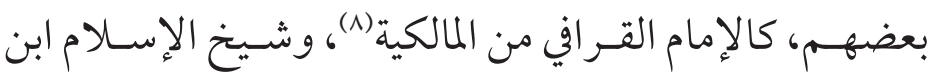
تيمية من الحنابلة (9).

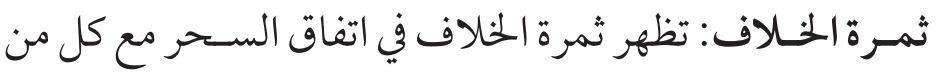

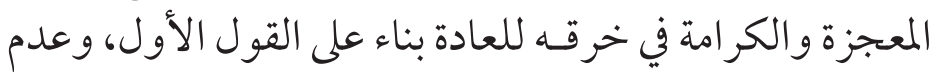
اتفاقه معها في ذلك بناء على القول الثاني.

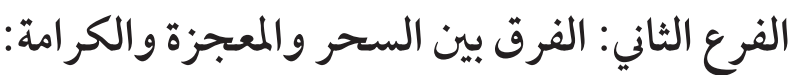

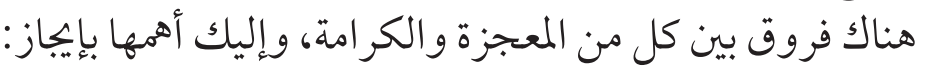

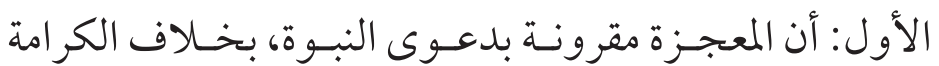

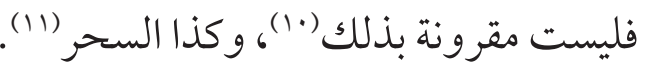
الثاني: أن كلا من السـحر و الكهانة يناله الإنسان بتعلمه وستعيه و اكتسابه -وهذا بجرب عند الناس - بخلاف النبوة فإنه لا ينالها

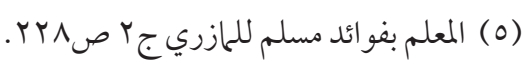

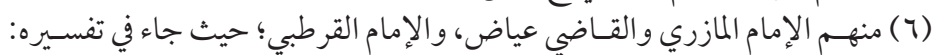

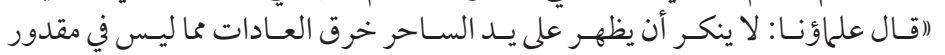

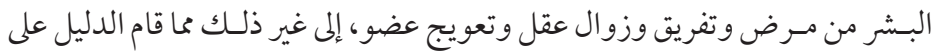

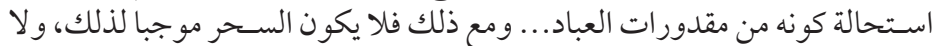

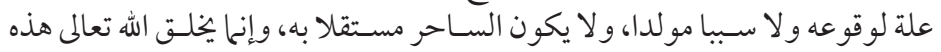

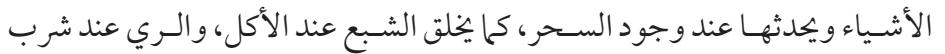

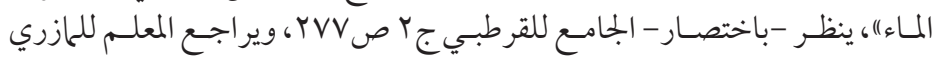

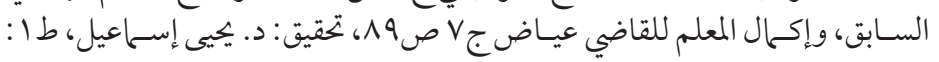

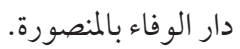

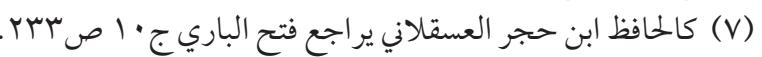

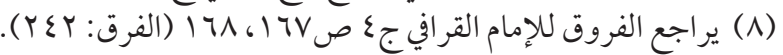

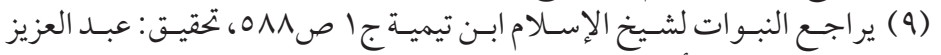

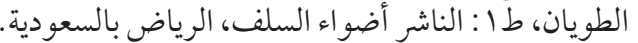

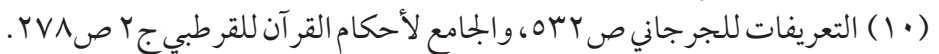
إمأ (11) يراجع الجامع للقرطبي المرجع السابق.

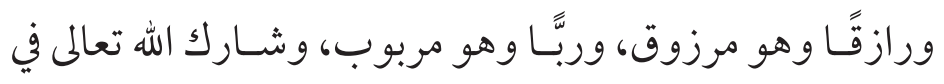
قدرته، وعارضه في حكمته. و الثاني: أنه لو قدر على هذا في غيره لقدر عليه فيه في نفسـهـ فيردها

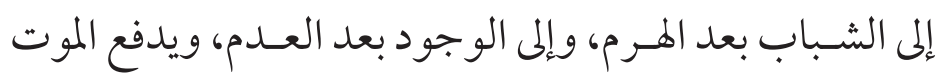
عن نفسه فصار من المخلدين، وباين جميع المخلوقين.

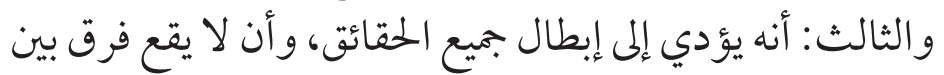
الحق والباطل.... (1).

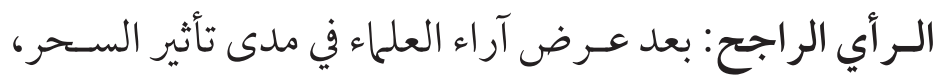

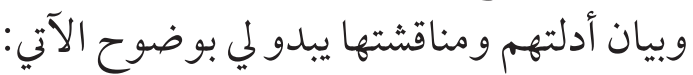

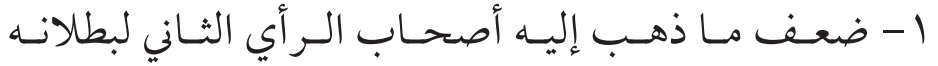

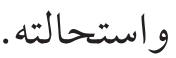

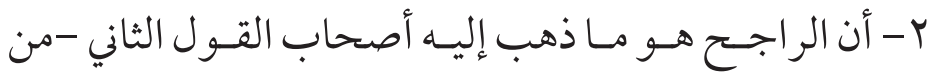

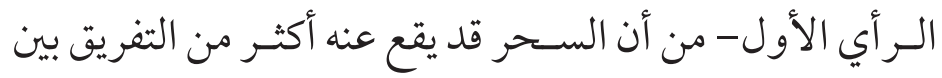

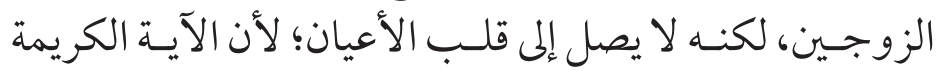
ليست نصَّا في منع الزيادة عليه -كما سبق - و الله أعلم.

\section{المطلب الخامس:}

\section{الفرق بين السحر والمعجزة والكرامة}

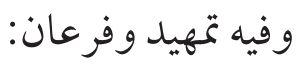
التمهيد: في التعريف بكل منها:

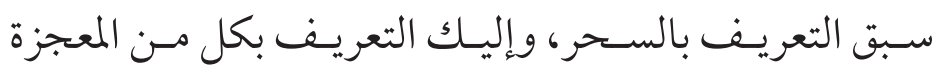

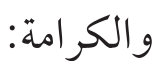

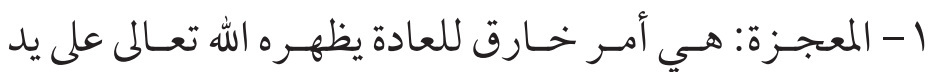

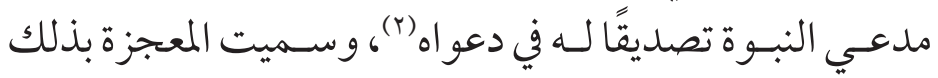
لعجز البشر عن الإتيان بمثلها (r).

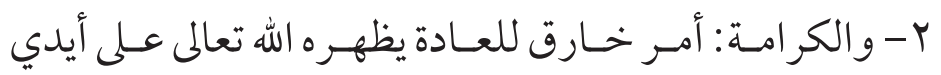

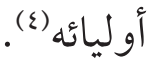

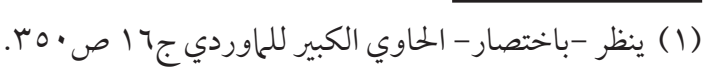

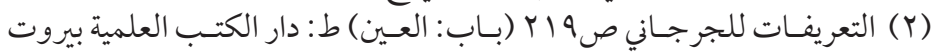

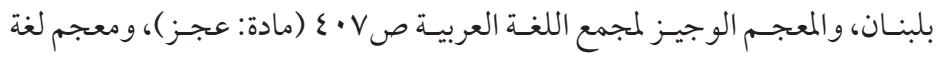

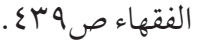

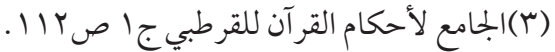

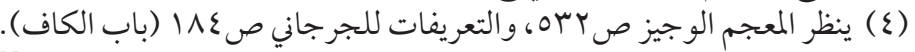




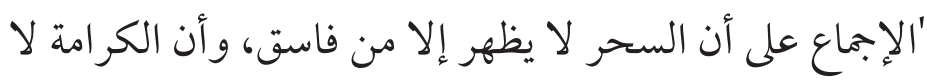

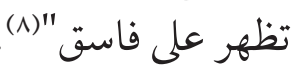
السـادس: أن السحر يختص بمن عمل له بخلاف المعجزة، وقد

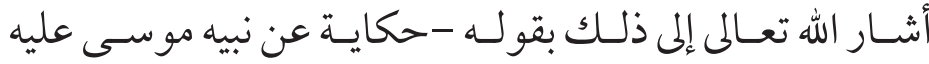

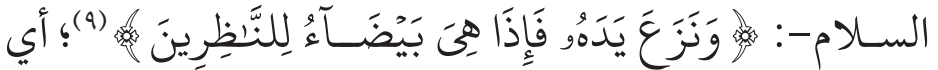

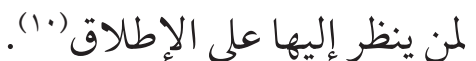

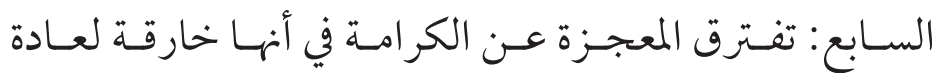

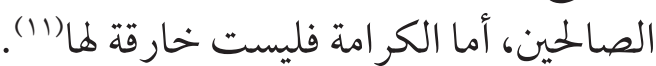

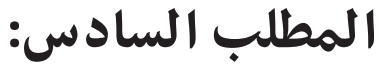 الألفاظ ذات الصلة بالسحر السطات}

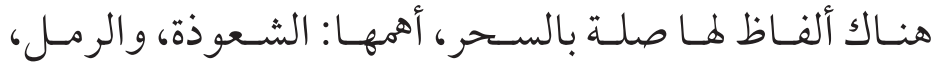

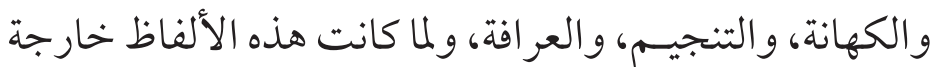
عن موضوع البحث؛ لذا سـأكتفي بتعريفهـا وبيان وجه صلتهانها

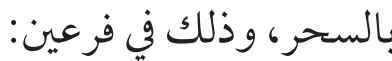

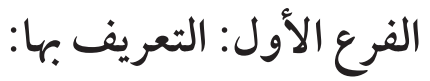

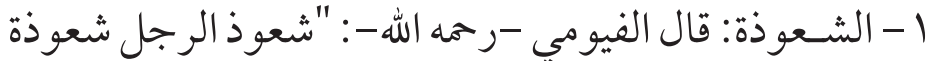

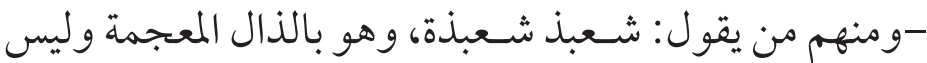

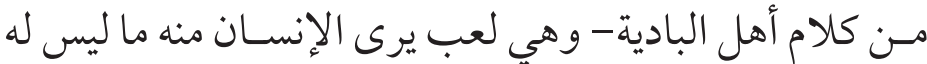
حقيقة كالسحر "(ir).

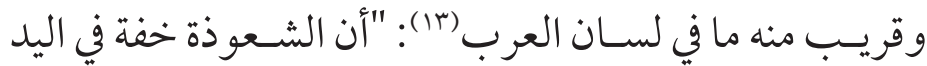

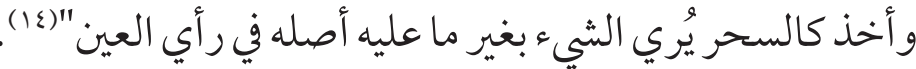

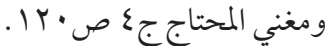

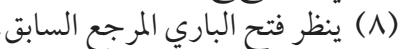

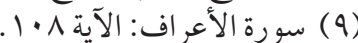

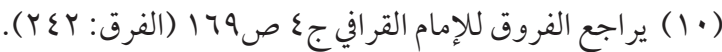

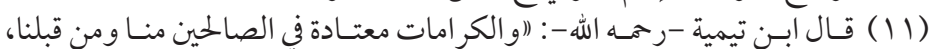

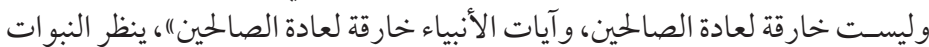

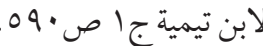

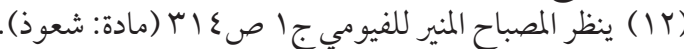

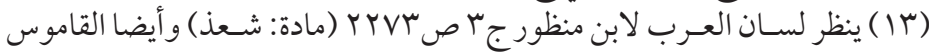

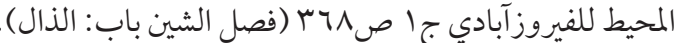

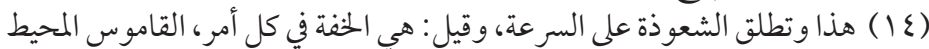

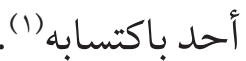

وأما الكر امة: فكثيرا ما تقع للولي اتفاقًا دون أن يفعل شيئًا (r).

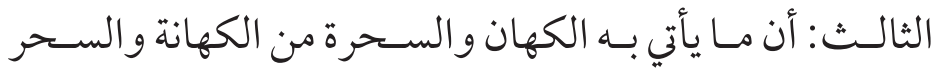

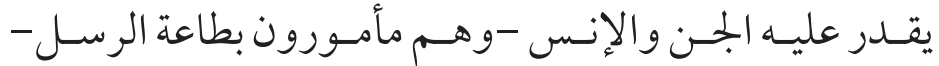

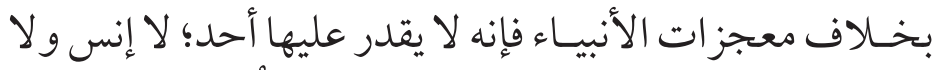

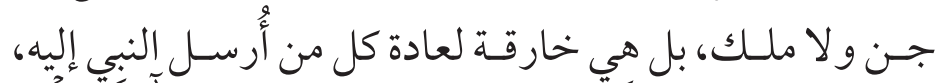

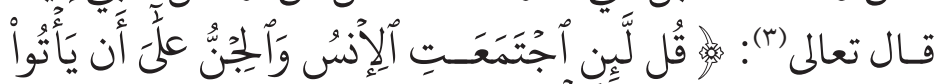

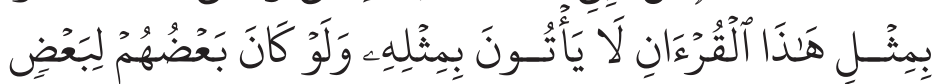

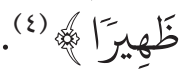

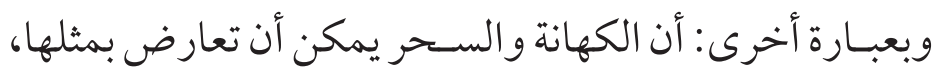

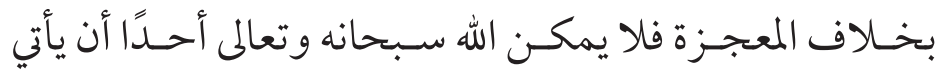

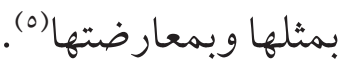

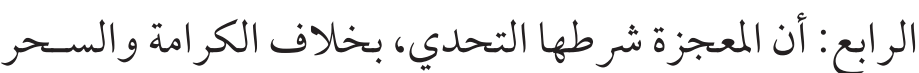

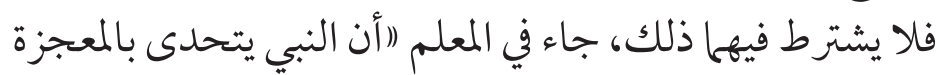

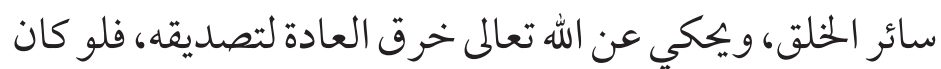

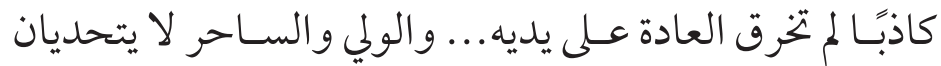

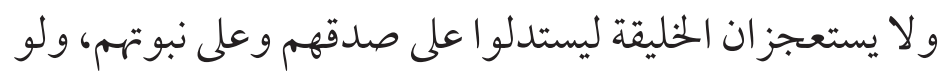

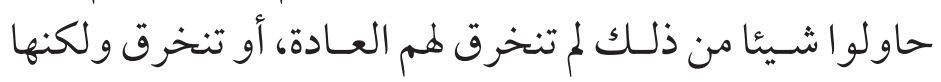

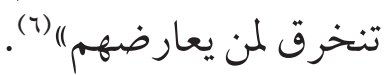

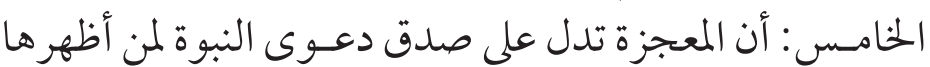

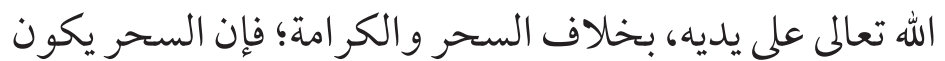

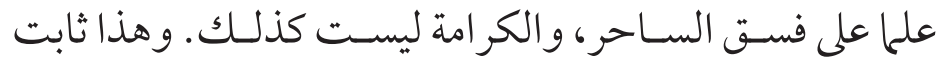

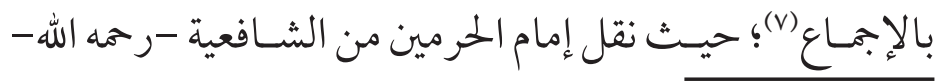

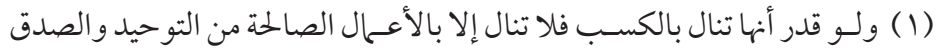

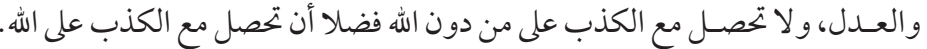

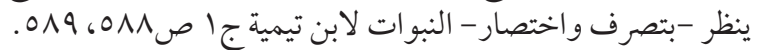

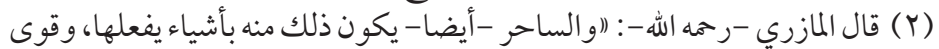

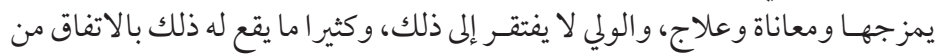

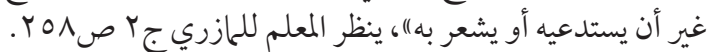

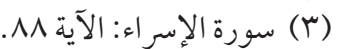

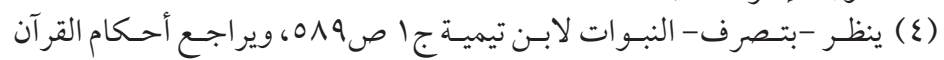

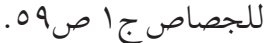

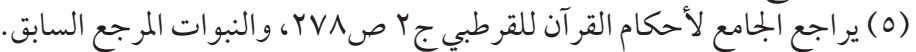

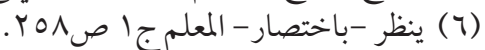

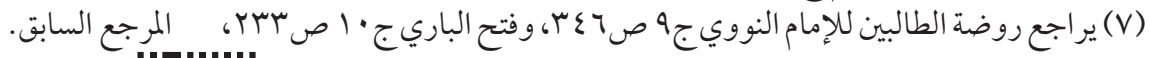


يزعمو ن أنهم يعلمون الغيب بأمور تلقى في نفوسهم (9). وعند الشافعية: الكهانة ادعاء علم الغيب كالإخبار بها سيقع في الإني

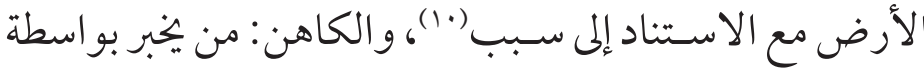
النجم عن المغيبات في المستقبل (11). وعند الحنابلة: الكاهن الذي له رَبئيُّن من الجن يأتيه بالأخبار (ri).

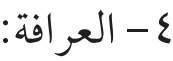

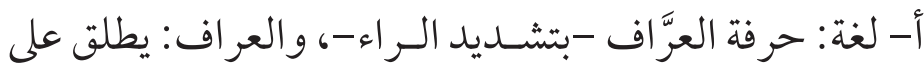

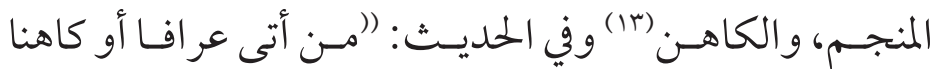

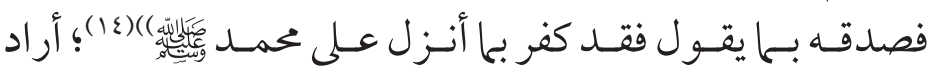

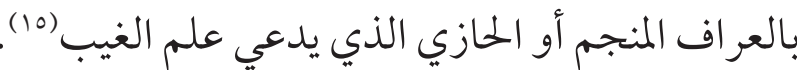

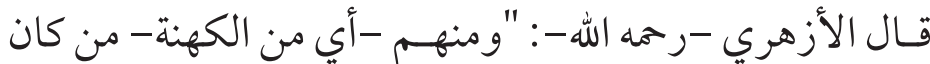

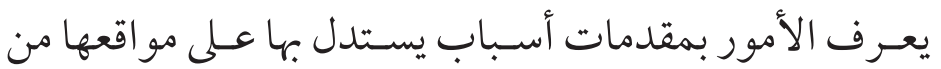

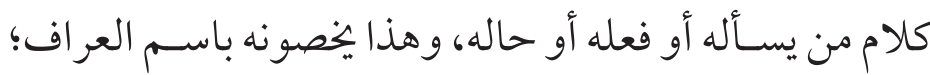
كالذي يدعي معرفة المسروق والضالة ونحوها" (1). وقيـل: العــراف هو الذي يخبر عن الماضي بخــلاف الكاهن فإنه

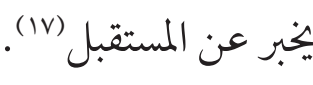
ب- بواصطلاحًا: عند الحنفية: العر اف؛ هو الذي يعرف الأمور بمقدمات يستدل

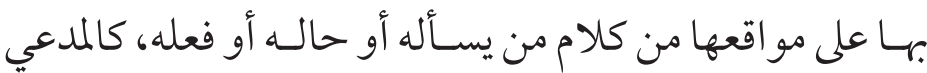

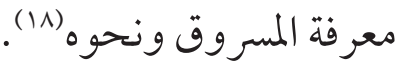

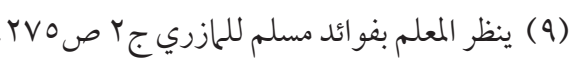

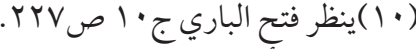

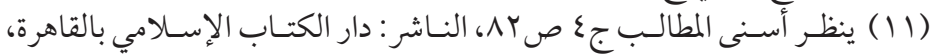

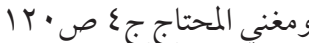

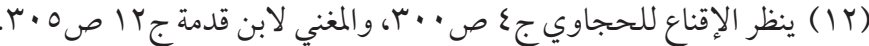

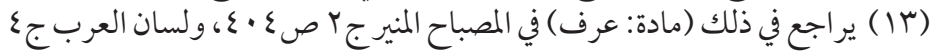

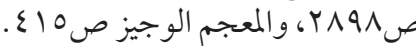

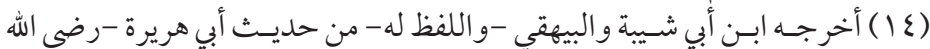

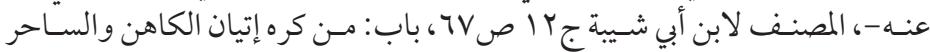

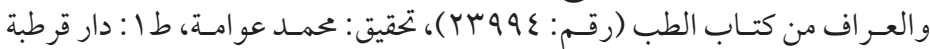

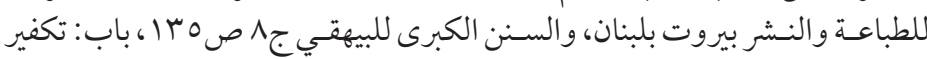
الساحر وقتله، من كتاب القسامة، الناشر: دار الكتاب الإن الإسلامي بالقاهرة.

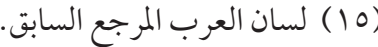

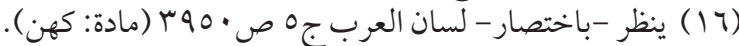
(IV) لإبل
أ- لغــة: هـو فتــات الصخر، وجمعه رمــال، و القطعـة منه رملة،

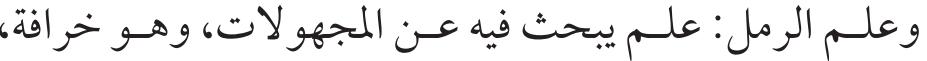
و الرمال: من يتعاطى علم الرمل : (1).

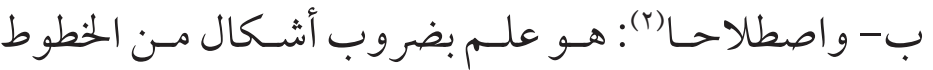

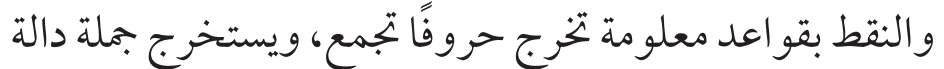

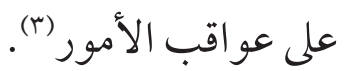

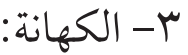

أ- لغــة: مصــر كهن؛ يقـال: كهن كهانة، صـار كاهنا، وتكهن

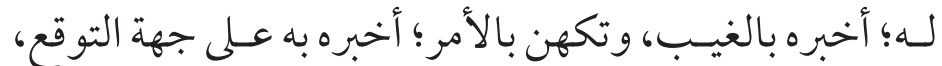

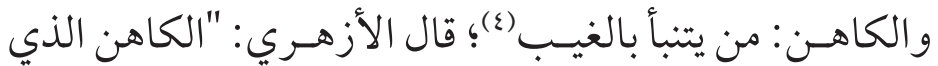
يتعاطى الخبر عن الكائنات في مستقبل الزمانسان ويدعي معرفة

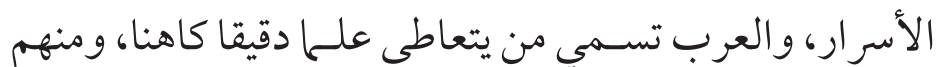

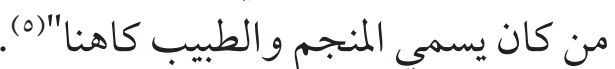
ويطلـق الكاهن -أيضا - على من يقوم بأمر الرجل ويسـى فئي

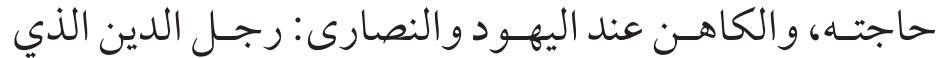

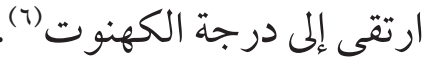

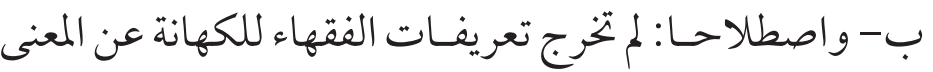

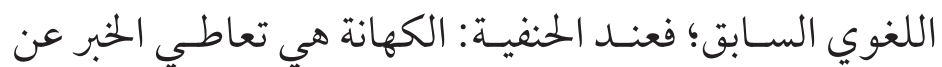

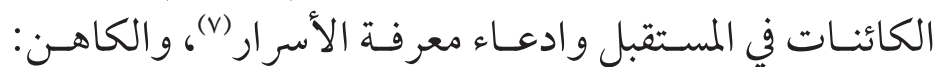

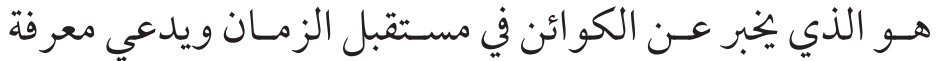
الأسرار ومطالعة الغيب (^). وعنــ المالكيـة: قال المـازري -رحمه الله - : أما الكهـان فهم قوم (Y) ينظر -باختصار - المعجم الوجيز لمجمع اللغة العربية صعVA (1) ، (مادة: رمل).

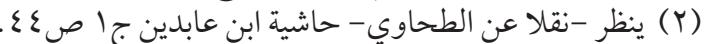

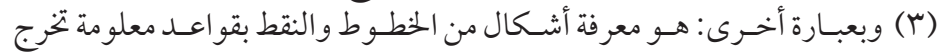

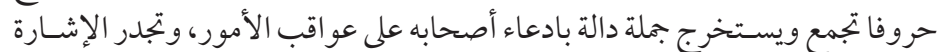

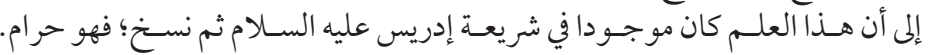

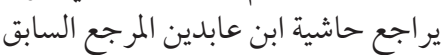

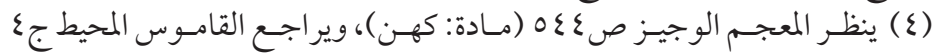
ص ص (ع ז، (فصل الكاف باب: النون).

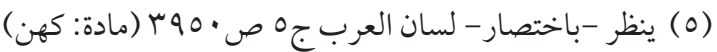

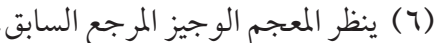

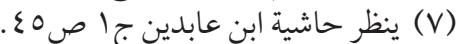

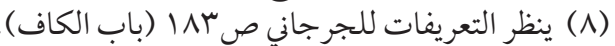


وعنـــ المالكيـة: العــراف؛ هو الذي يسـتدل على أمور بأسـباب الحو ادث(9).

\section{الفرع الثاني: وجه صلتها بالسحر:} إن الألفاظ السابقة لماصلة وطيدة بالسحر، حيث إنها فالنها -الشعوذة

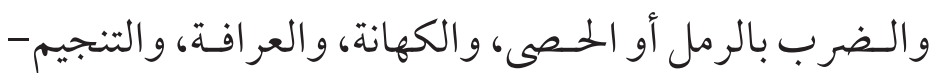

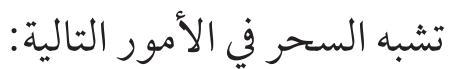

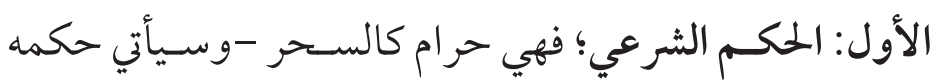

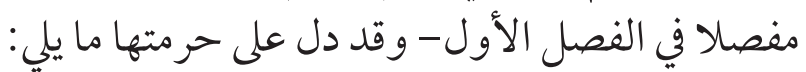

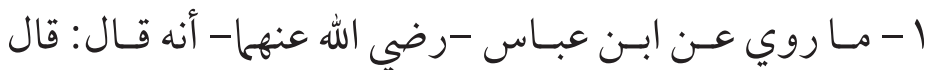

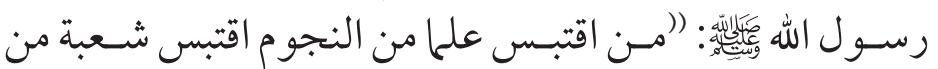
السحر زاد ماز زاد)(·(1).

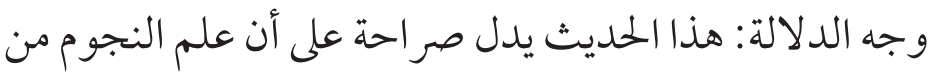

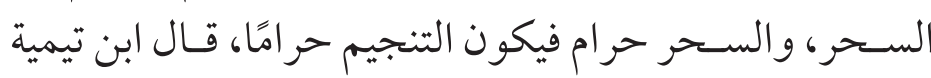

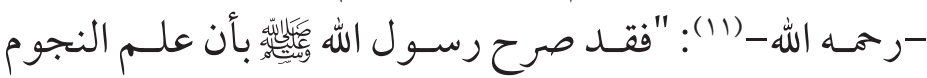

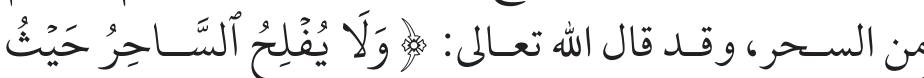

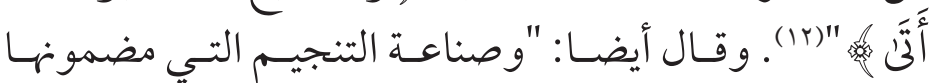

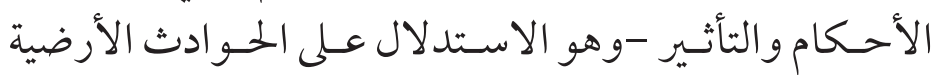

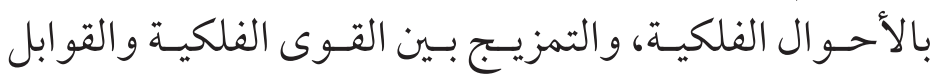

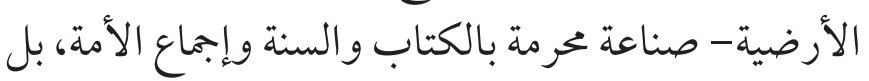

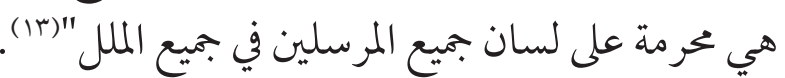

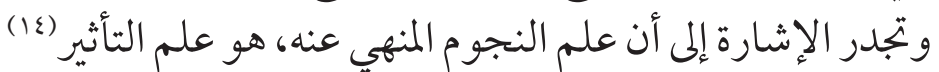

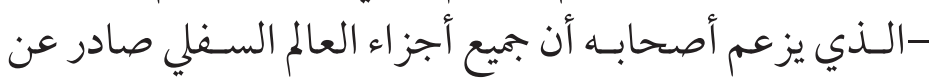

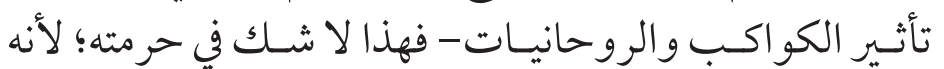

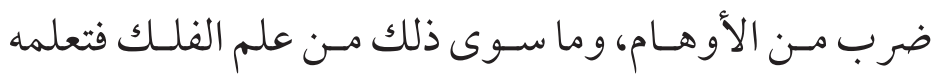

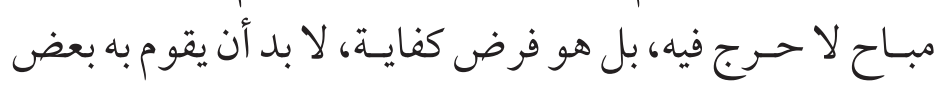

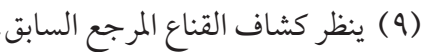

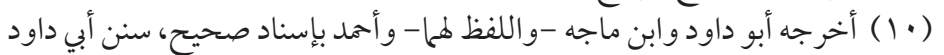

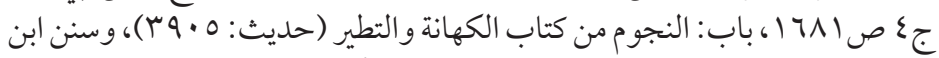

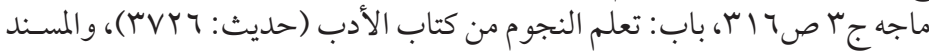

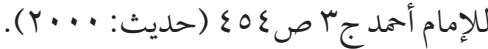

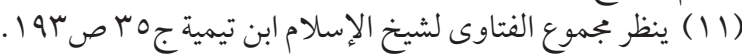

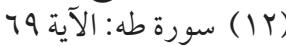

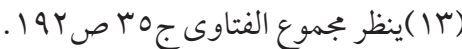

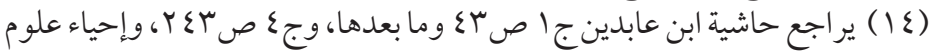

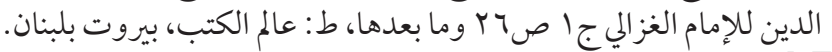

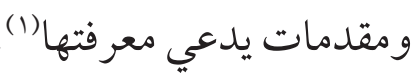
وعند الشافعية: عرفوه بتعريفين:

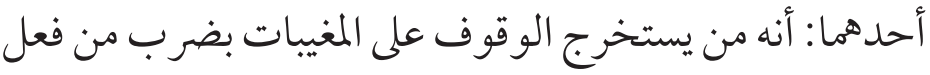

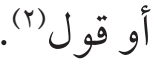
والثاني: أنه الذي يخبر عن المغيبات الو اقعة كعين السارق ومكان المسروق والضالة (r). وعند الحنابلة: العراف هو الذي يجدس ويتخرص (2). وهذه التعريفات متقاربة ولا تخرج عن المعنى اللغوي السابق.

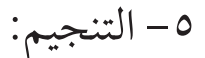

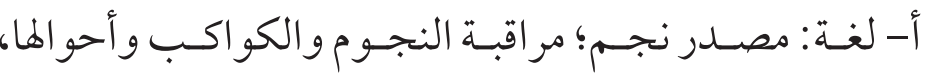

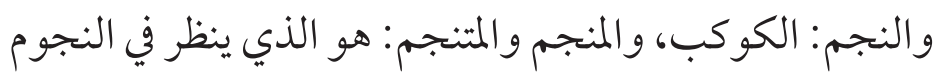

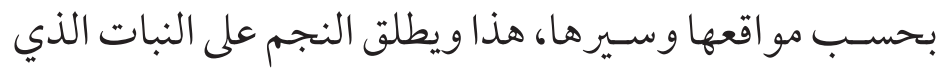

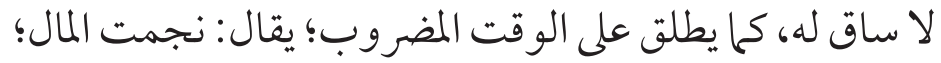

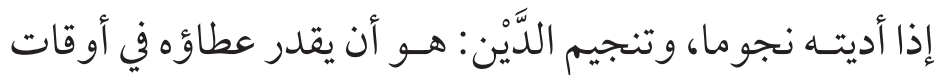
معلومة متتابعة (0). ب- و واصطلاحـا: علـم يعـرف بـهـ الاسـتدلال بالتشـكيلات الفلكية على الحو ادث إثلاث الأرضية(7)، وفي معجم لغــة الفقهاء: "ظن معرفة الغيب بالنظر

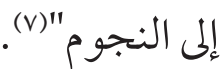
والمنجم: هو الذي يخبر عن المستقبل بطلوع النجم وغروبه (^).

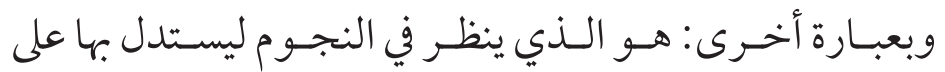

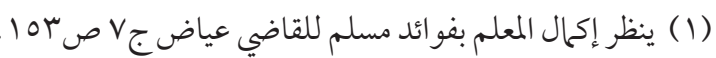

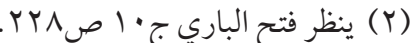

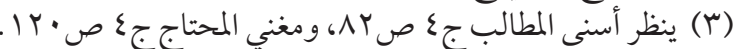

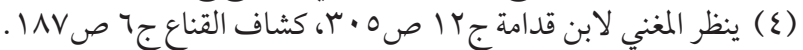

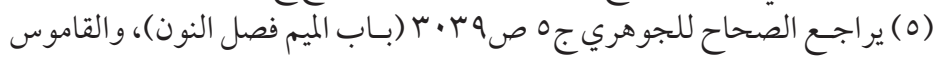

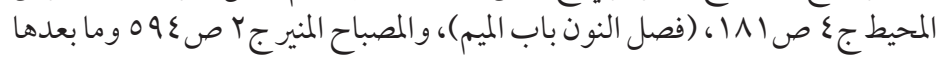

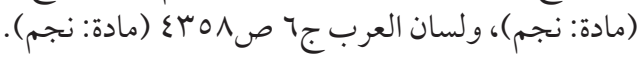

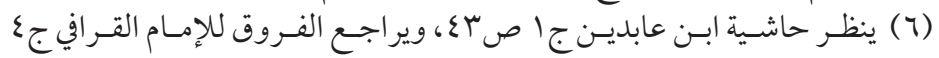

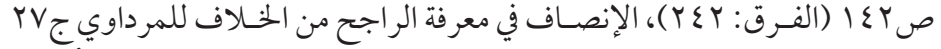

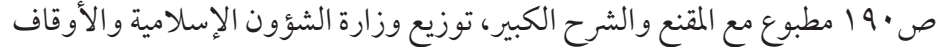

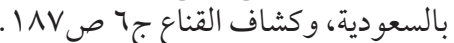

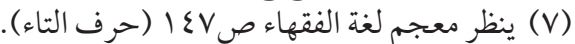

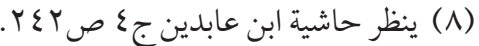




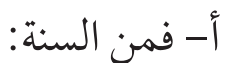

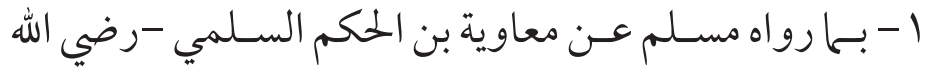

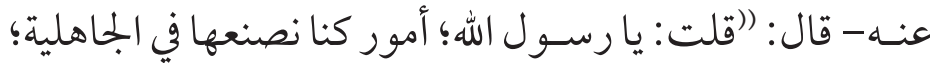

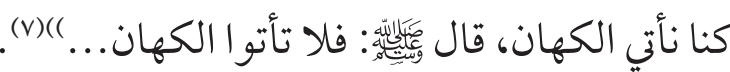

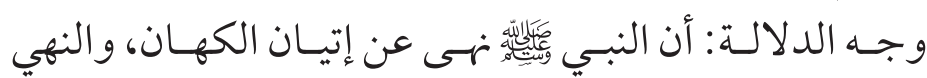
للتحريم، فدل ذلك على تحريم إتيانهم (^).

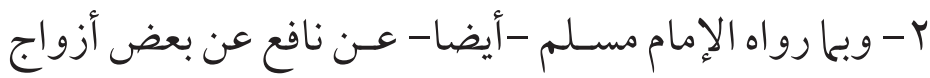

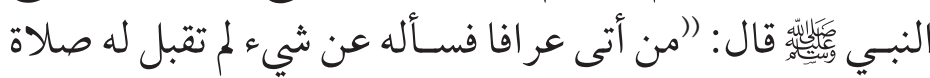

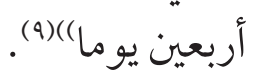

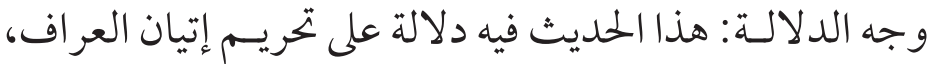

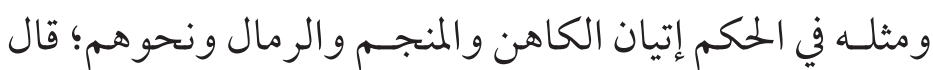

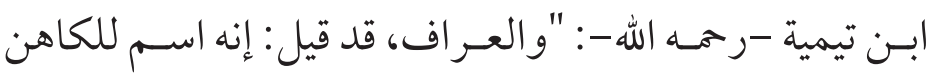

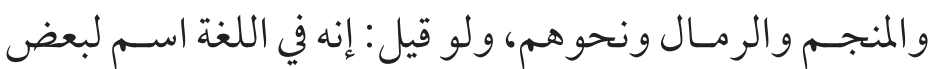

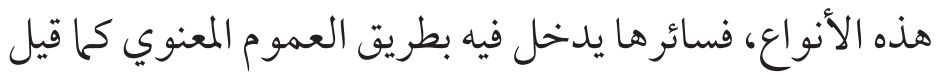

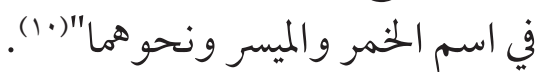

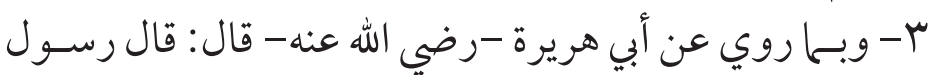

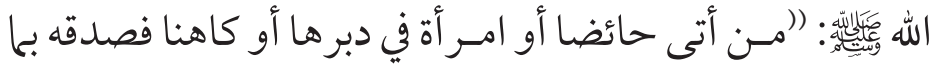

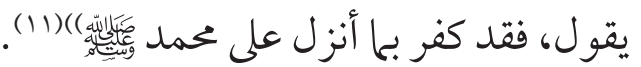

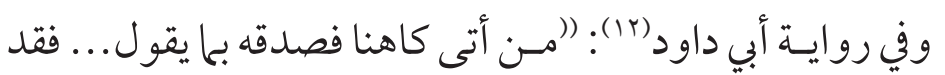

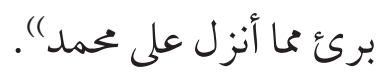

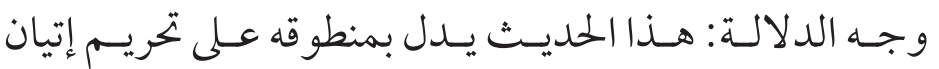

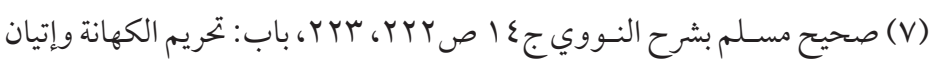

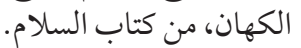

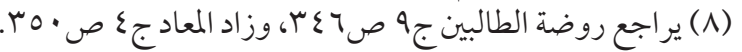

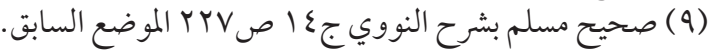

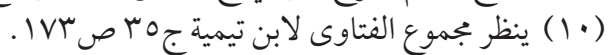

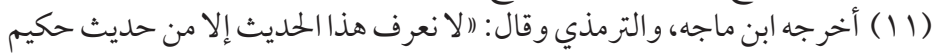

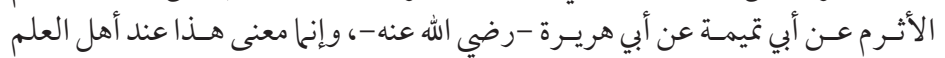

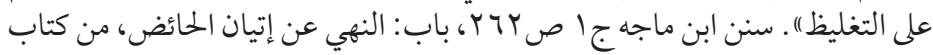

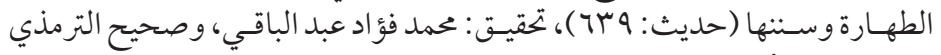

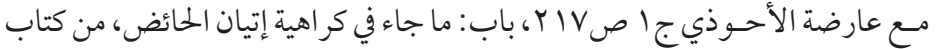

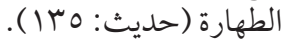

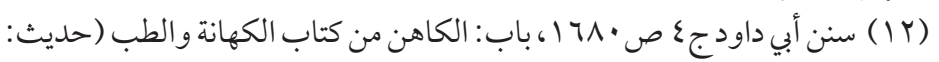

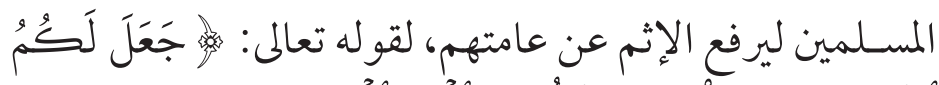

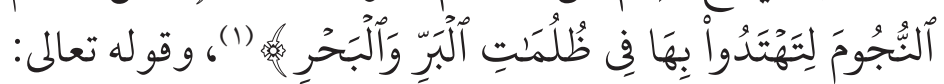

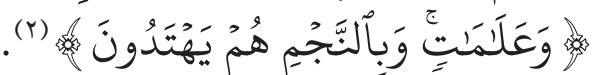

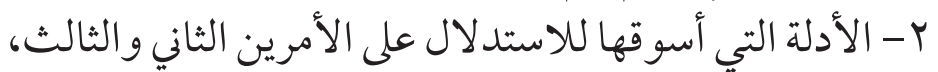

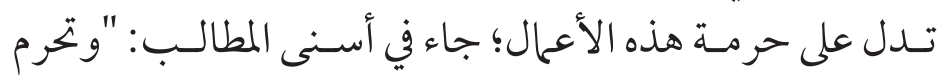

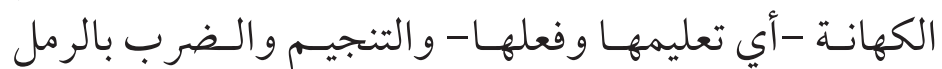

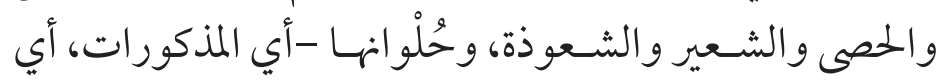

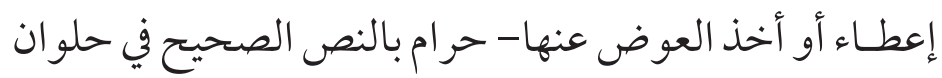

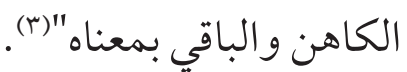

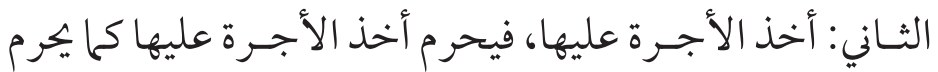

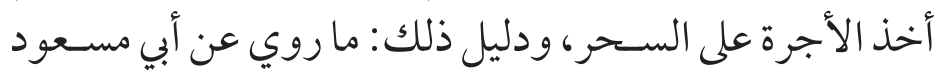

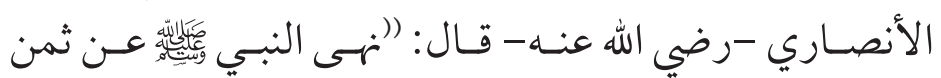

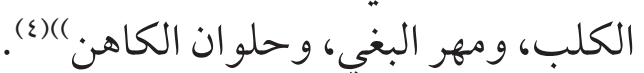

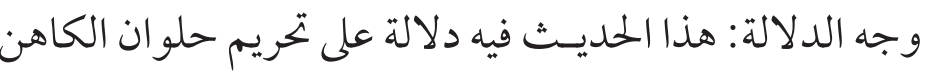

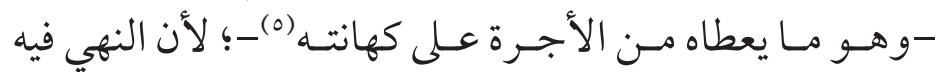

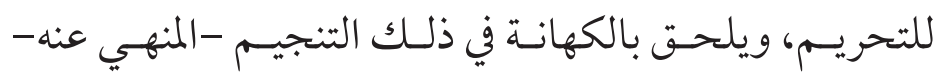

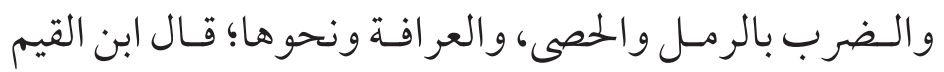

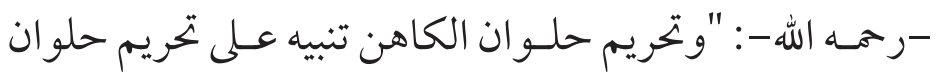

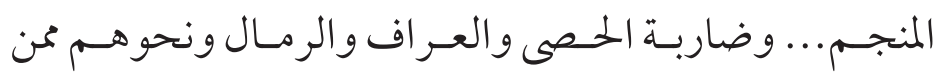

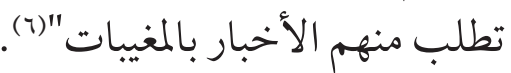

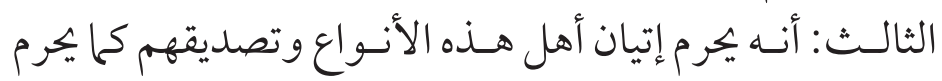
إتيان الساحر وتصديقه، وقد دل على ذلك السنة والأثر:

(Y) (1) سورة الأنعام: آية

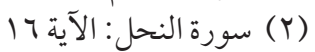

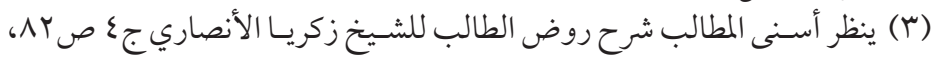

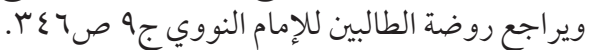

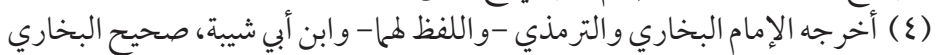

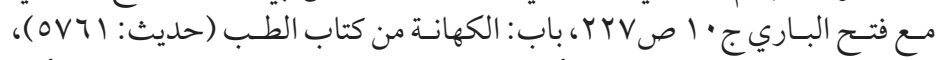

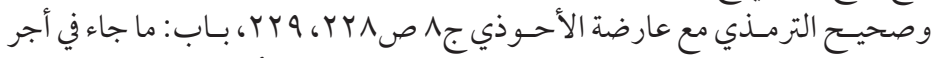

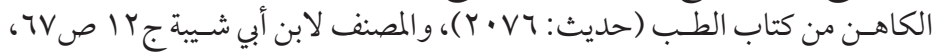

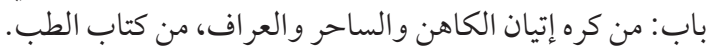

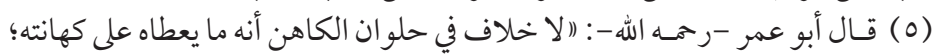

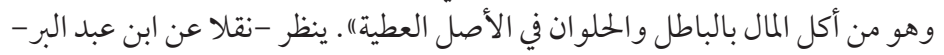

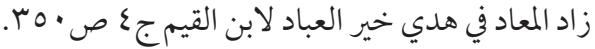
(7) ينظر زاد المعاد لابن القيم المرجع السابق. 


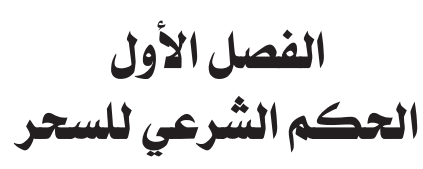

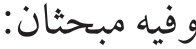

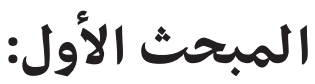

الحكم الشرئ لفعل السحر

سـأبين بمشــيئة الله تعالى الحكـــم الأصلي لفعل السـحر، ثم أتبع ذلك بييان الأحكام الأخرى التي تعرض له، وذلك في مطلبين:

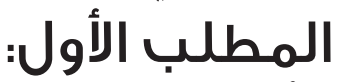

\section{الحكمم الأصلي لفعل السحر}

اتفق الفقهاء على حرمة فعل السـحر، وعلى أنه من الكبائر، وقد

دل على ذلك السنة النبوية والإجماع (0):

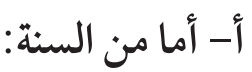

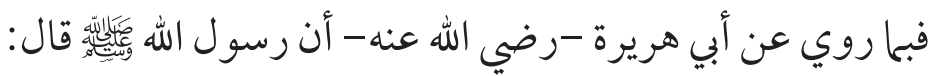

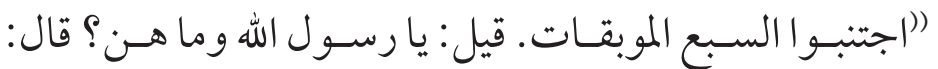

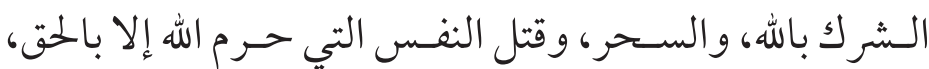

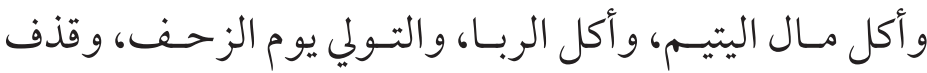
المحصنات الغافلات المؤمنات)(آ).

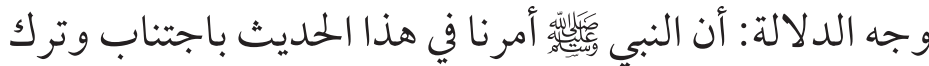

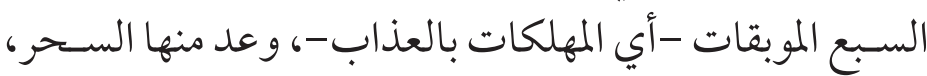

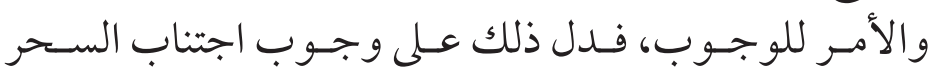
وحرمة فعله (v). ب- وأمـا الإجمـاع: فقد أبمعت الأمة الإسـالامية عـلى أن فعل

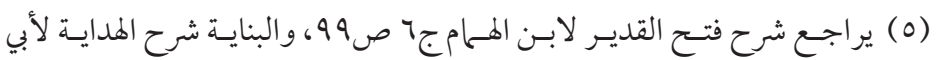

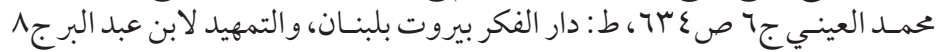

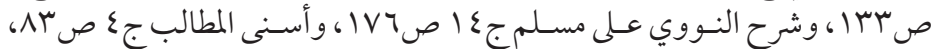

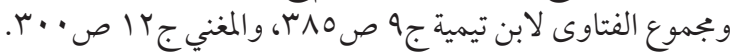

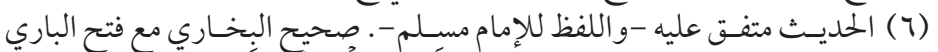

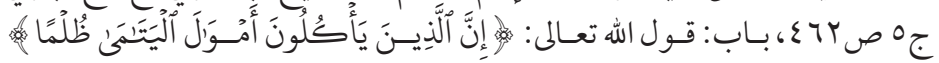

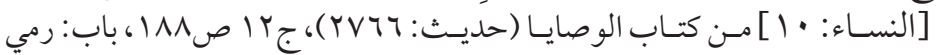

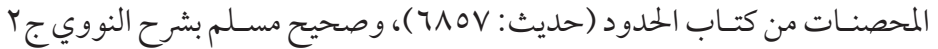

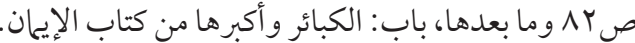

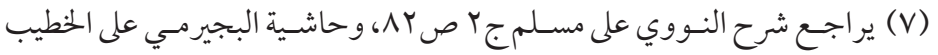

الكاهـن وتصديقـه وكذلك العراف والمنجــم (1)؛ قال ابن الأثير

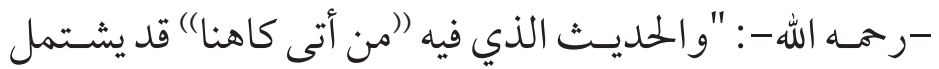
على إتيان الكاهن و العر اف و المنجمي" (r).

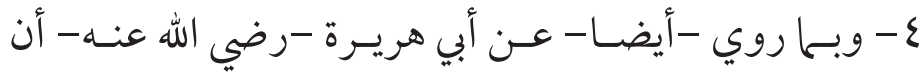

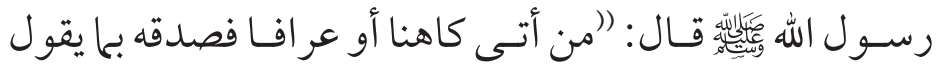
فقد كفر بها أنزل على محمد)(").

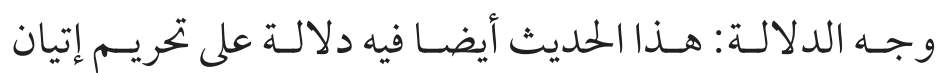
الكاهن و العراف وتصديقها.

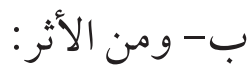
بما أخر جه ابن شيبة عن عبد الله بن مسعود -رضي الله عنه- أنه

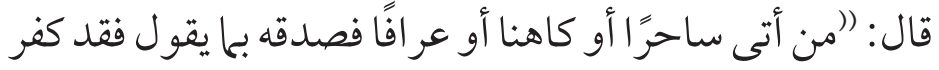

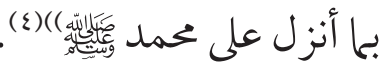

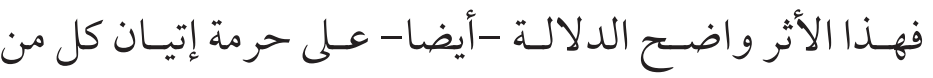

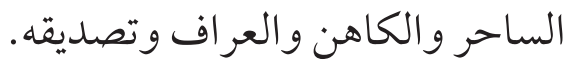

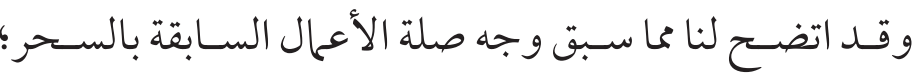
لشبهـا به في الأمور الثلاثة المتقدمة. والله تعالى أعلم المبه

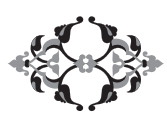

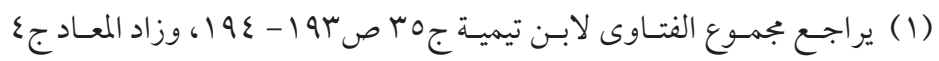

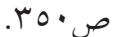

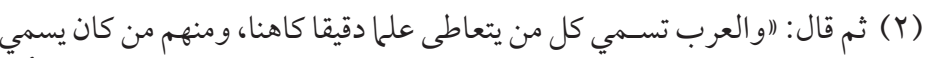

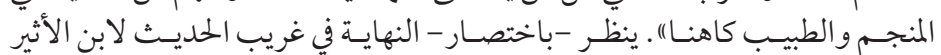

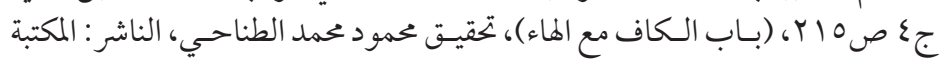

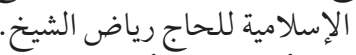

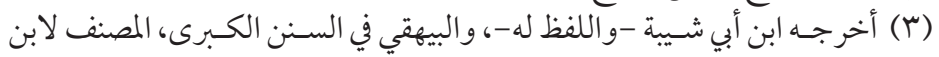

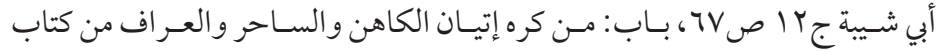

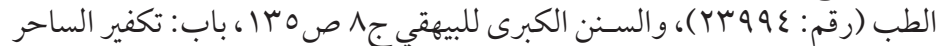
وقتله... - من كتاب القسامة. (ع) ) المصنف لابن أبي شيبة الموضع السابق. 


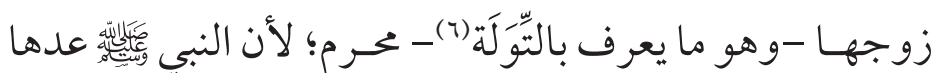

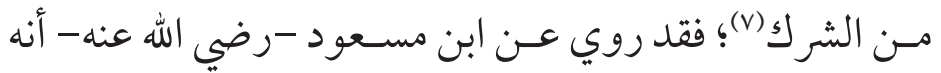

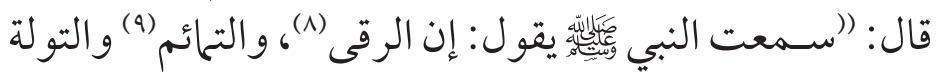

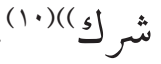

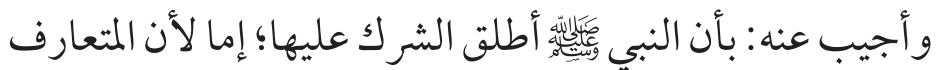

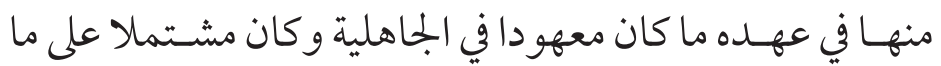

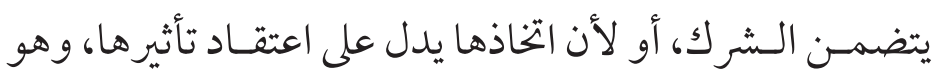

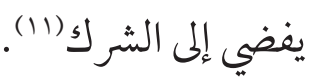

\section{المبحث الثاني \\ الحكم الشري لتعلم السحر وتعليمه}

اختلف الفقهاء في حكم تعلم السحر وتعليمه على ثلاثة آراء:

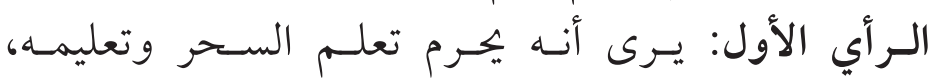

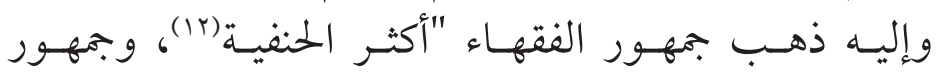

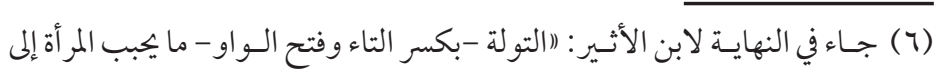

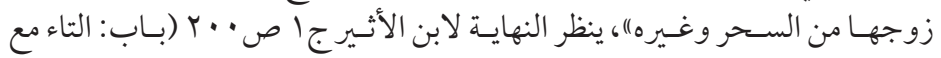

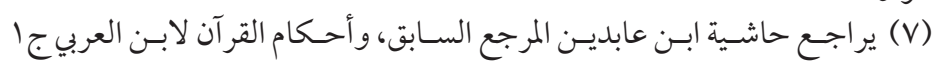

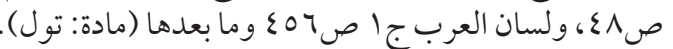

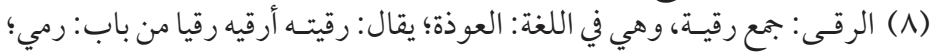

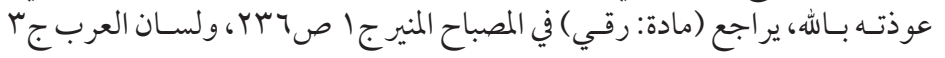
ص ص

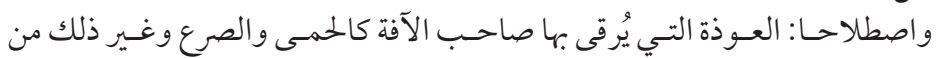

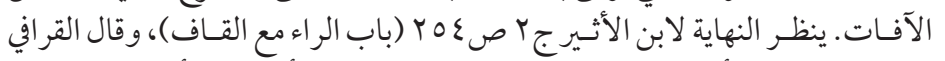

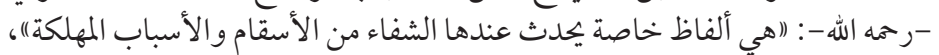

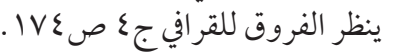

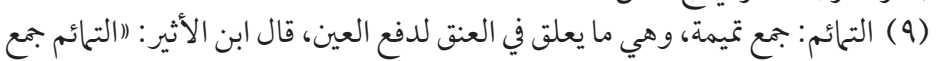

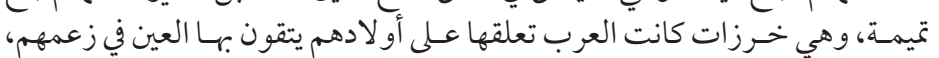

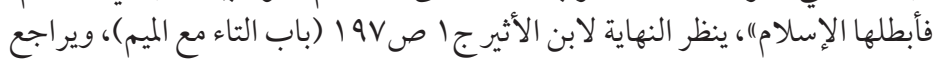

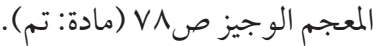

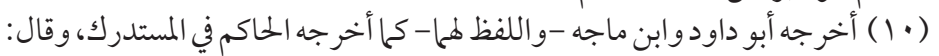

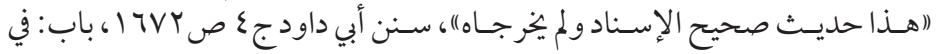

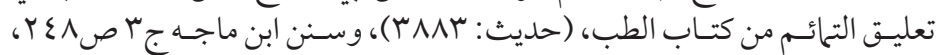

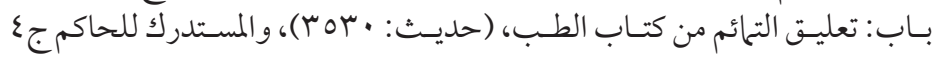

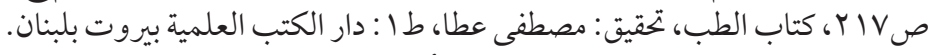

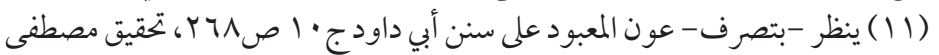

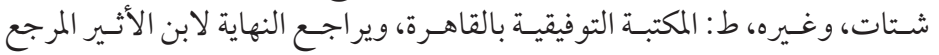

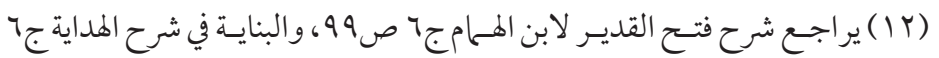

السحر محرم وعلى أنه من الكبائر (1).

فرع: حكم من اعتقد إباحة السحر :

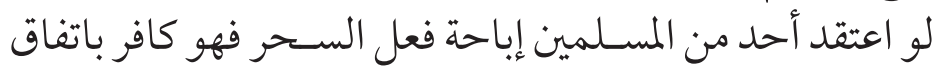

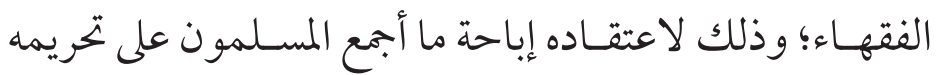
قياسا على ما لو اعتقد تحليل الزنا فإنه يكفر (r).

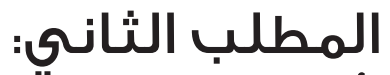

الأحكامم الأخرى التـي تعرّي: لفعل السحر السئر

علمنا سابقا أن الحكم الأصلي لفعل السحر ومباشرته هو الحرمة، الحقا.

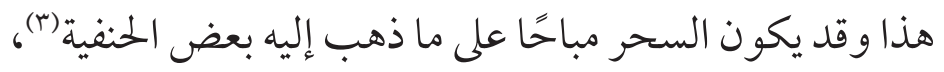

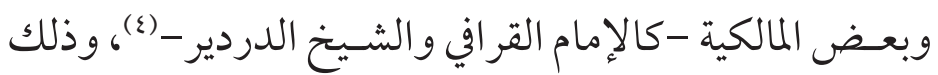

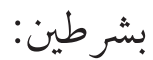
الأول: أن يفعـل بأمــــــاح شرعا؛ كالآيات القر آنية، أو أسـهاء

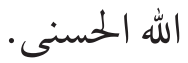

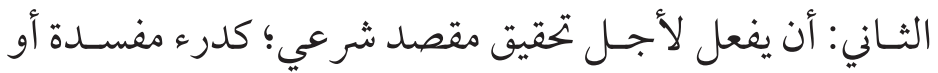

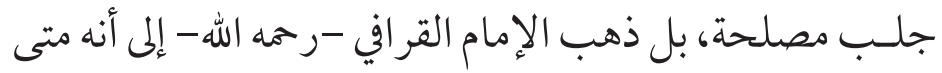

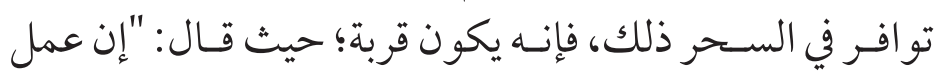

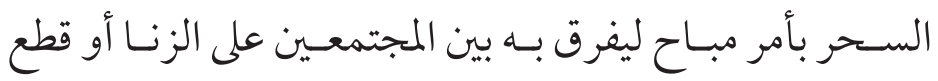

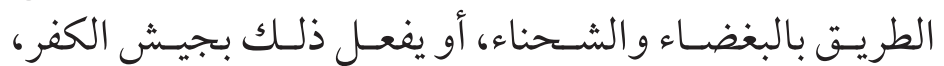

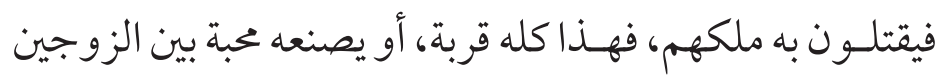

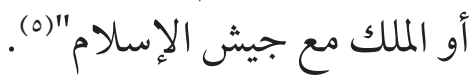

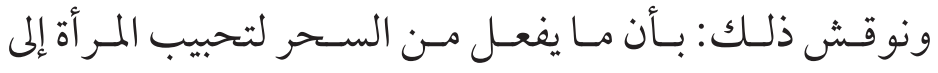

(1) قال الإمام النووي -رهمه اللها-: إفعمل السحر حرام، وهو من الكبائر بالإجماع"ا،

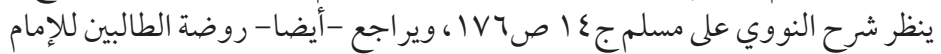

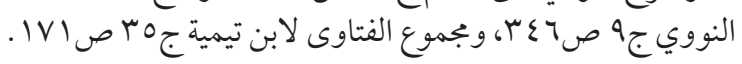

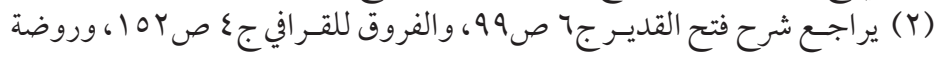

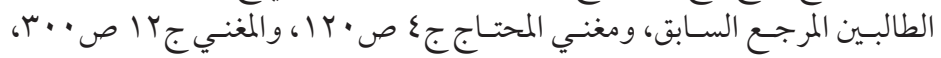

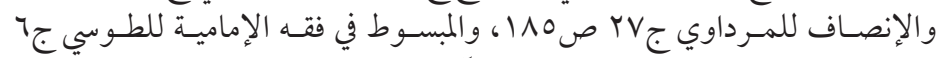
ص. صآث، الناشر: المكتبة المرتضوية لإحياء آثار الجعفرية. (؟)

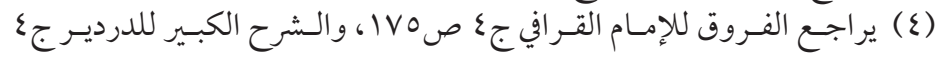
ص.r. (s) (0) - (0 يظر الفروق للإمام القرافي المرجع السابق. 


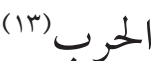

جـ-- ويكــون حر امـا: إذا كان الغرض منه إلحـاق ضرر بالغير؛

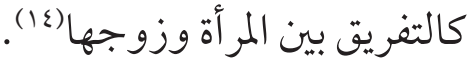

الأدلة ومناقشتها:

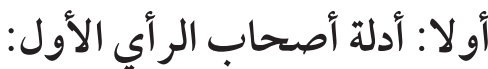

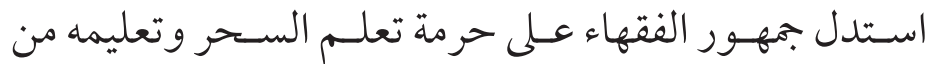
القر آن و السنة و المعقول:

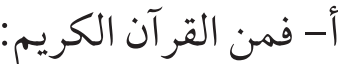

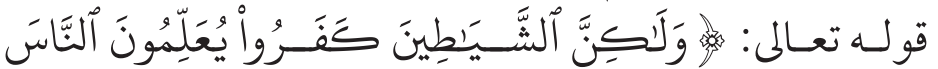

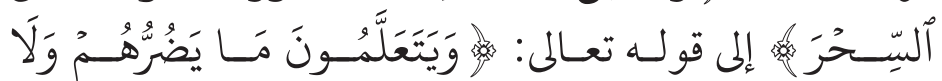

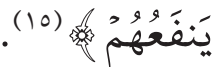
وجـهـ الدلالة: أن الله سـبحانه وتعالى قد ذم في هـذهـ الآية تعليم السحر وتعلمه، فدل ذلك على حرمته)| (17).

ب- بومن السنة النبوية:

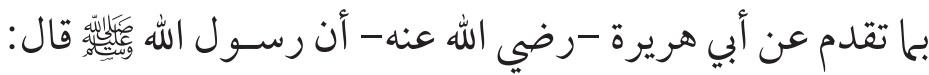

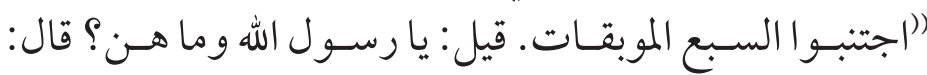

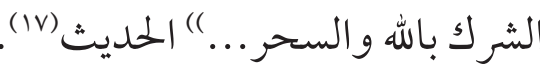

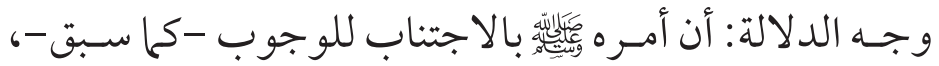

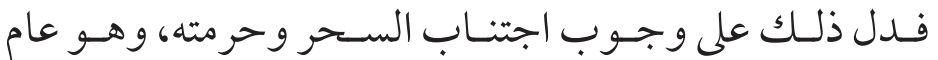
يشـمل بعمو مه فعل السـحر وتعلمه وتعليمـه، فيكون كل منها حر اما.

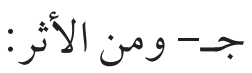

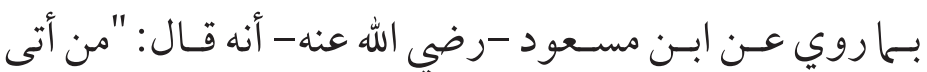

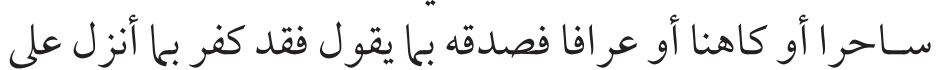

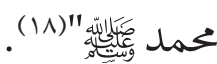

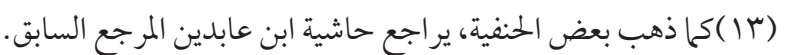

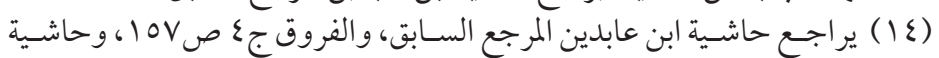

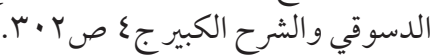

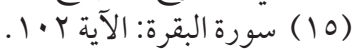

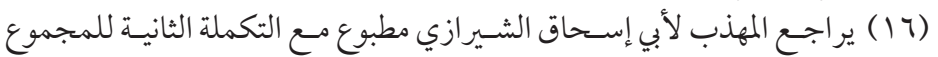

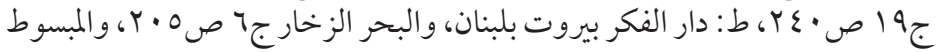

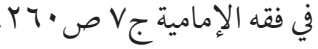

(IV)

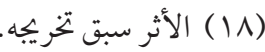

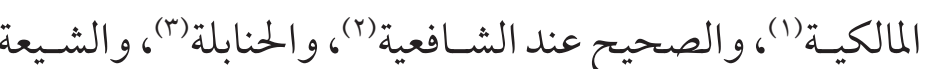

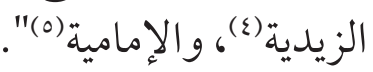

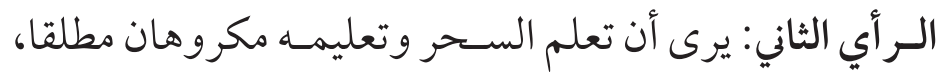

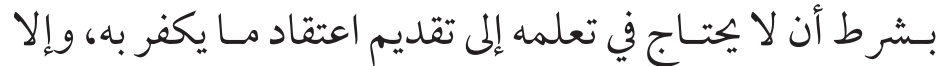
صار حرامًا، و إليه ذهب الشافعية في الوجه الثاني (r).

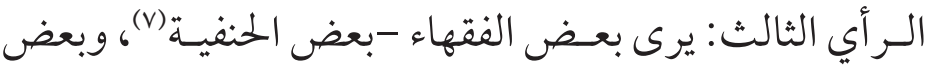

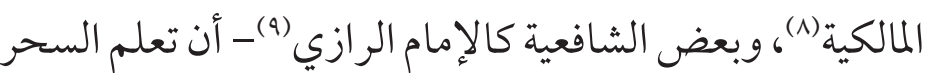

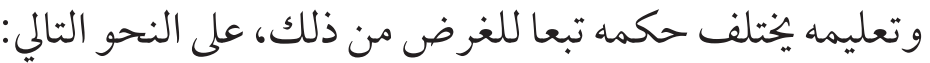

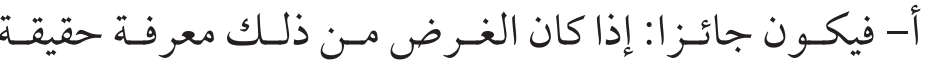

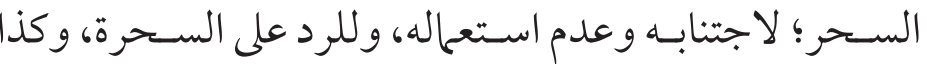

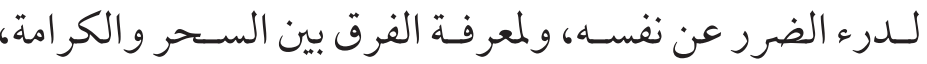

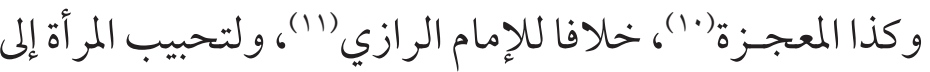

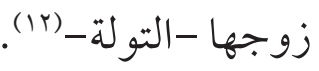
ب- ويكـون فرضـا: إذا كان الغـرض منـه رد ســاحر أهـل

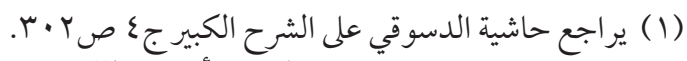

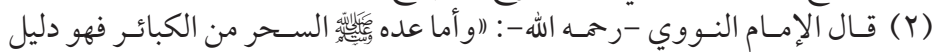

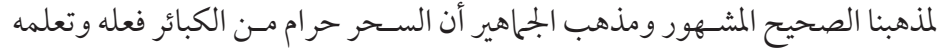

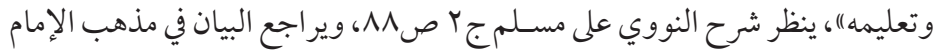

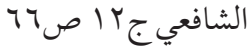

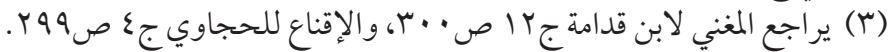

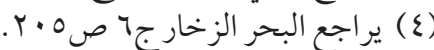

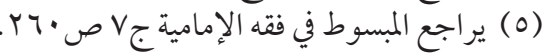

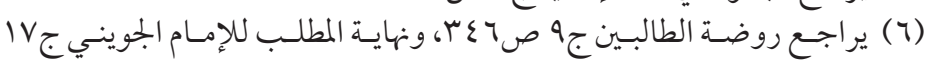
ص •

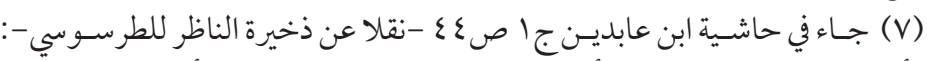

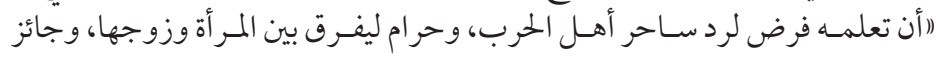

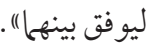

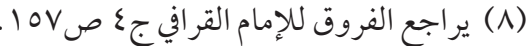

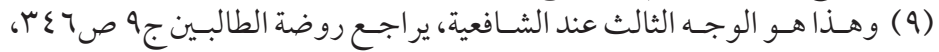

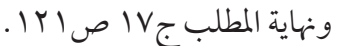

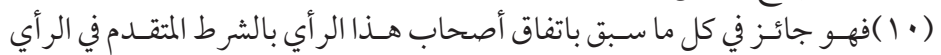

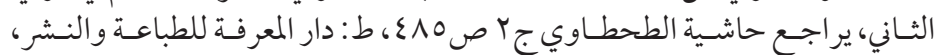

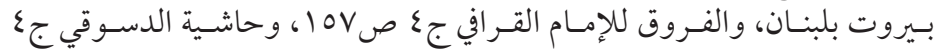

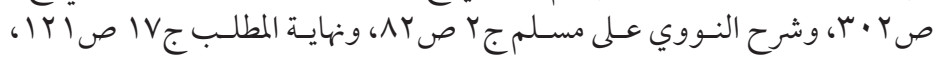
و ومغني المحتاج المرجع السابق.

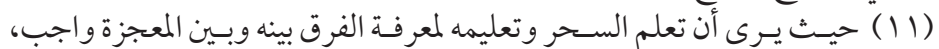

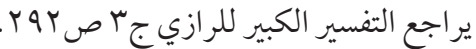

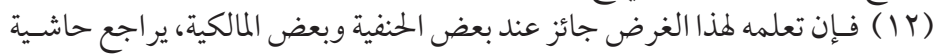

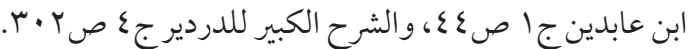




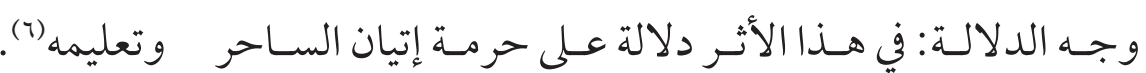

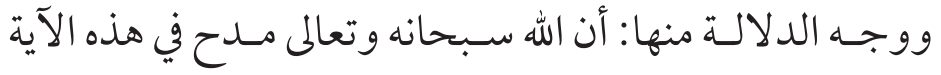

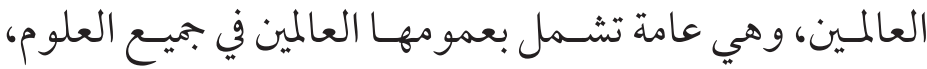
ومنها علم السحر، فدل ذلك على جواز تعلمه وتعليمه.

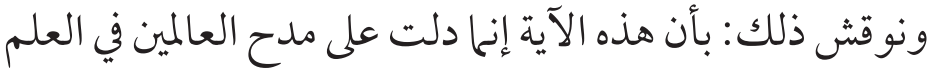

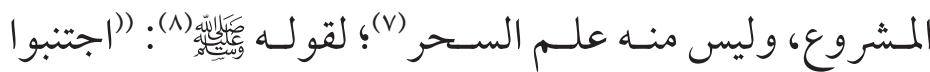

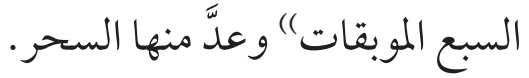

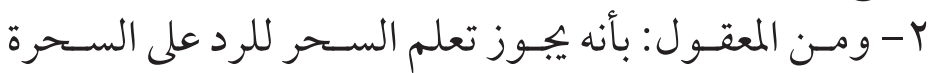

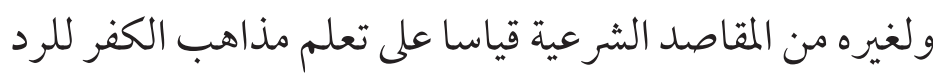

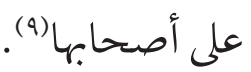

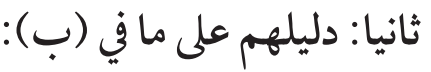

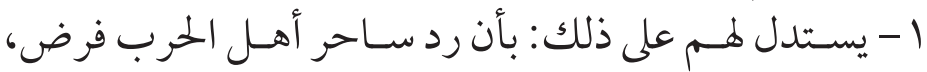

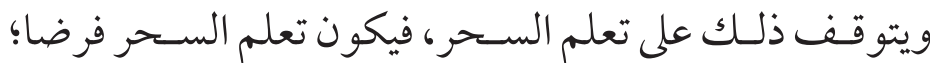

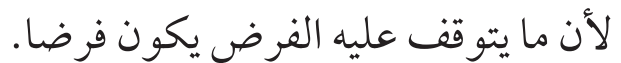

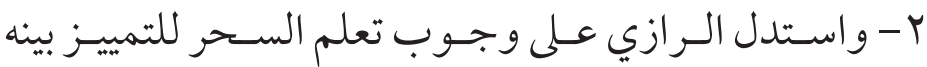

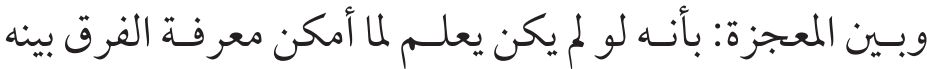

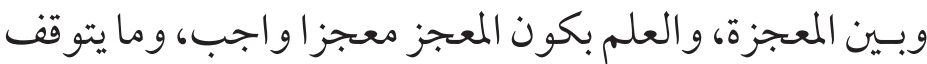
عليه الواجـب فهو واجب، فهذا يقتضي أن يكون تحصيل العلم بالسحر واجبا.(1). ونوقش ذلك: بأن القول بوجوب تعلم السـحر؛ لأنه لا يجصل

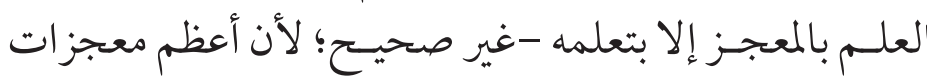

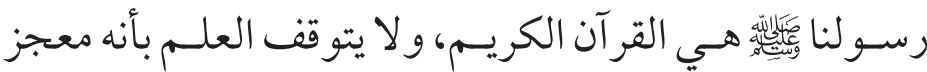

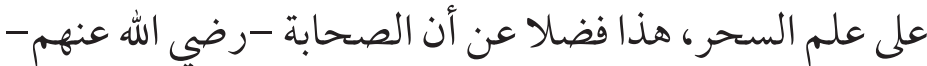

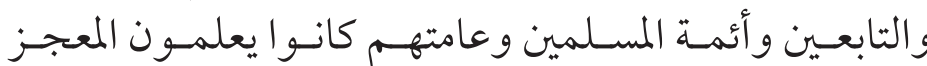

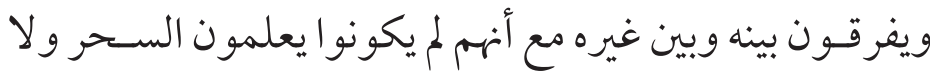

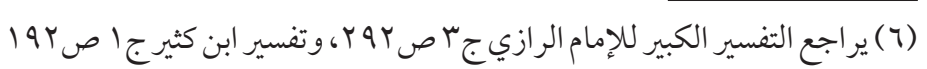

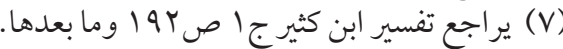
(1) الحديث سبق تخريه.

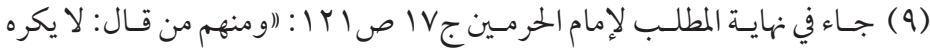

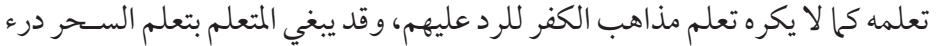

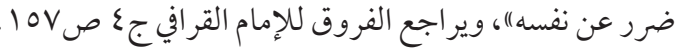
| (1) ينظر -بتصرف- التفسير الكبير للرازي المرجع السابق.

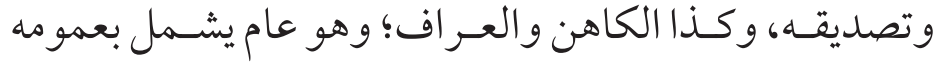

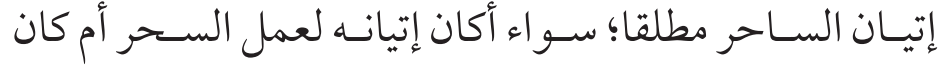

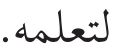

د- ومــن المعقول: بأن تعلم السـحر يؤدي إلى الإضرار بالناس؛ لأنه داع إلى فعله.

وبعبارة أخرى: أنه لا يتصور تعلم السـحر إلا بمباشرته قياسـا

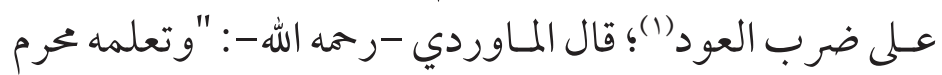
مخظور؛ لأن تعلمه داع إلى فعله و العمل به، و ما دعا إلى المالى المحظور كان مخظورا"(r)

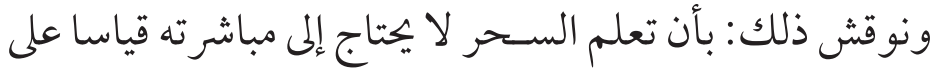
تعلم أنواع الكفر الذي لا يكفر به الإنسان (r).

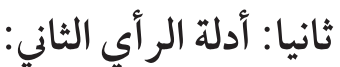
استـدل القائلون بكر اهية تعلم السحر وتعليمه بأن في الدين ما

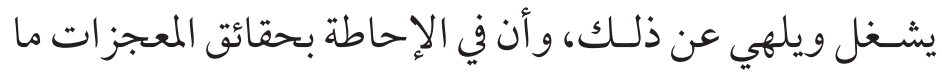

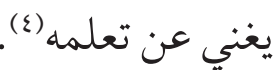

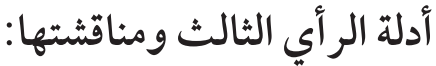

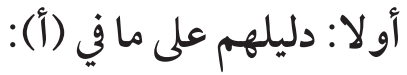

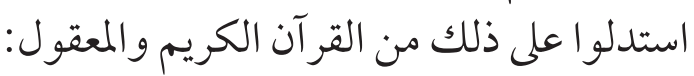

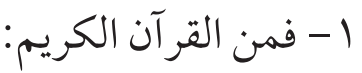

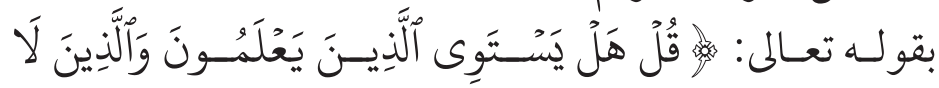

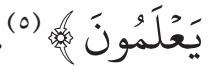
فقد اسـتدل الإمـام الـرازي بعمومها عـلى جواز تعلم السـحر

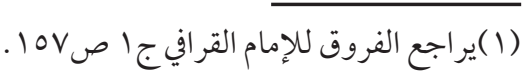

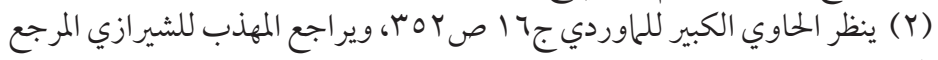
السابق.

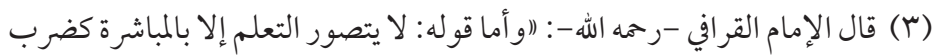

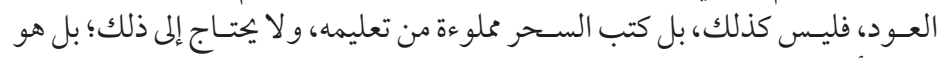

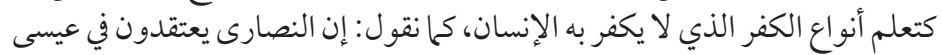

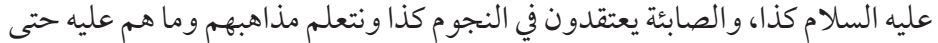

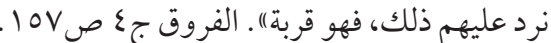

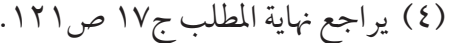
(0) سورة الزمر: الآية 9. 


\section{الفصل الثاني \\ تكفير الساحر التياني}

اختلف الفقهاء في تكفير الساحر المسلم بمباشرته للسحر -فعلا أو تعلما أو تعليما- على رأيين:

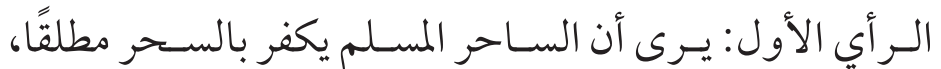

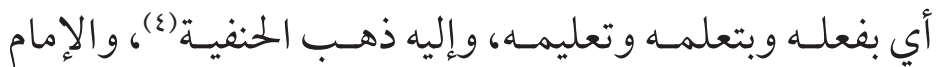

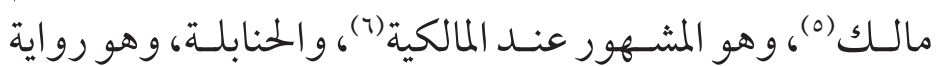

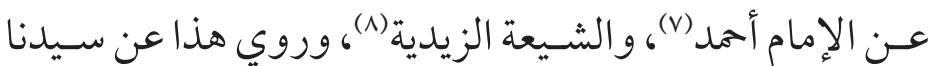
علي رضي الله عنه (9). الـر أي الثاني: يرى عدم تكفير المسـلم بفعل السـحر و لا بتعلمه

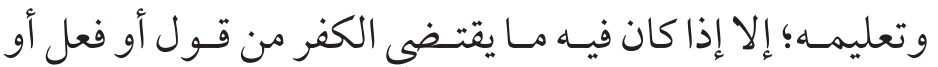

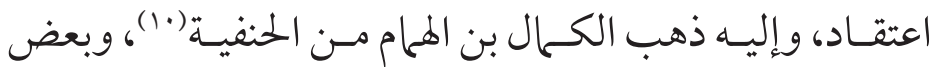

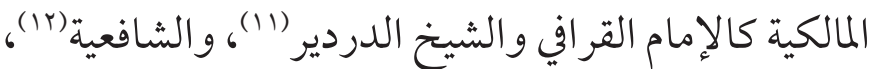

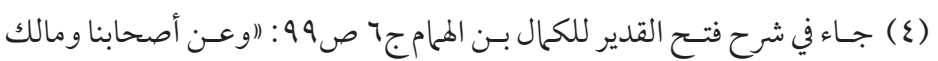

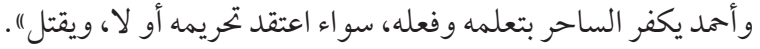

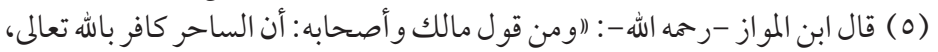

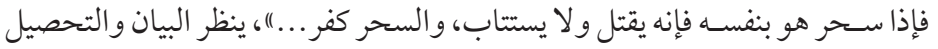

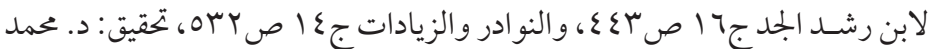

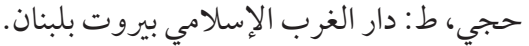

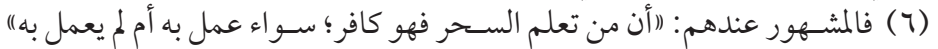

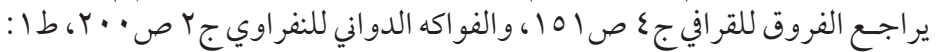

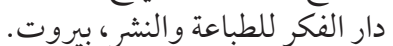

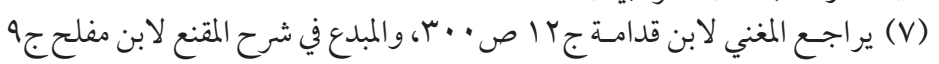

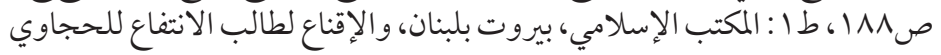

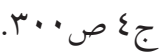

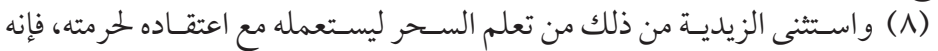

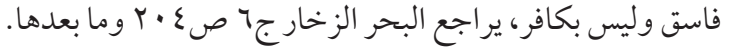

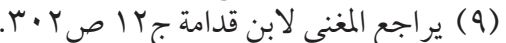

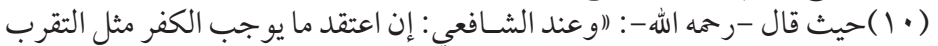

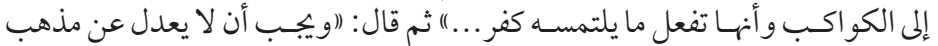

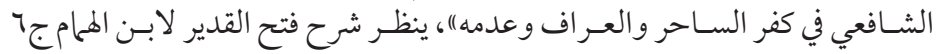
ص

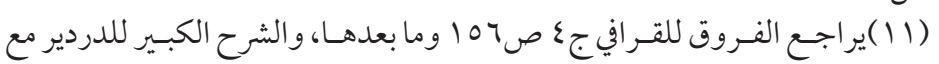

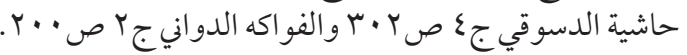

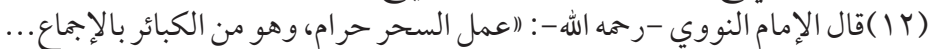

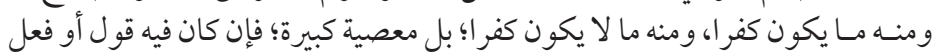

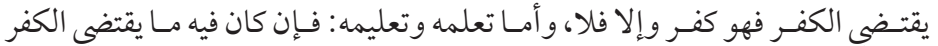

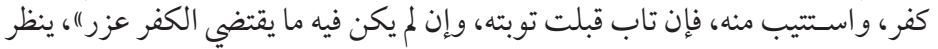

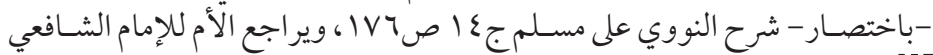

تعلموهو لا علموه (1).

ثالثا: دليلهم على ما في (جـ): يستدل لهم: بما روي عن عمرو بن يجيى المازني عن أبيه أن رسول

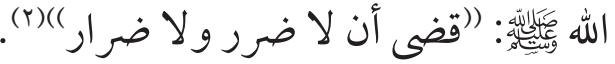

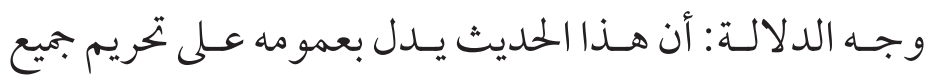

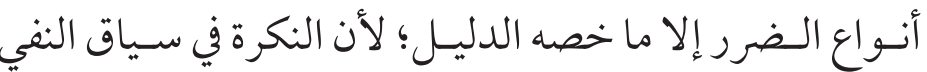

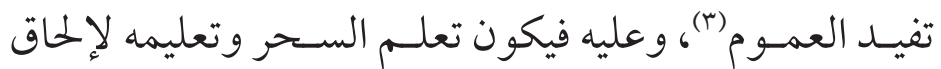
الضرر بالغير حرامًا. والـــي أميـل إليه: هـو ما ذهـــب إليه أصحسـاب الـرأي الثالث

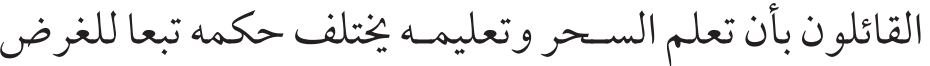

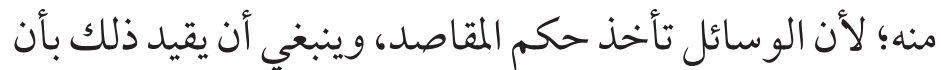

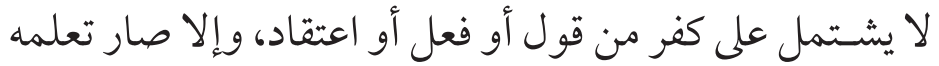

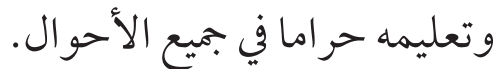
والله أعلم الأم

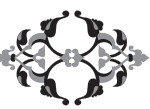

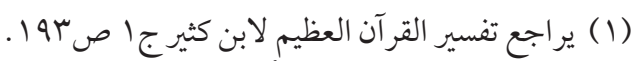

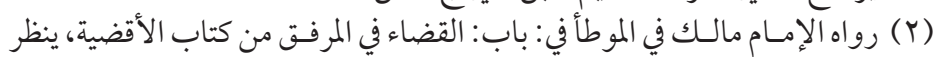

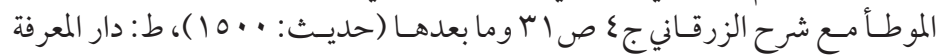

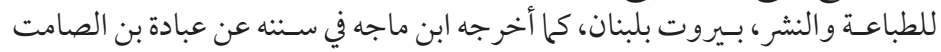

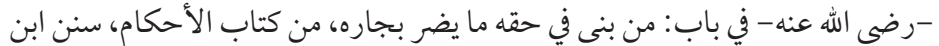

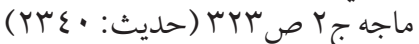

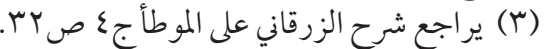


أ- بـــأن مـا جـاء في الآية حكاية حـال، ويكفـي في صدقها حالة

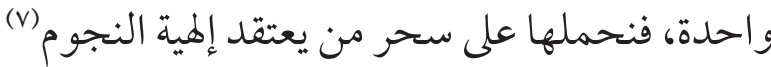

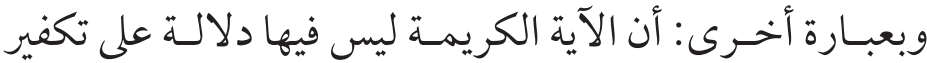

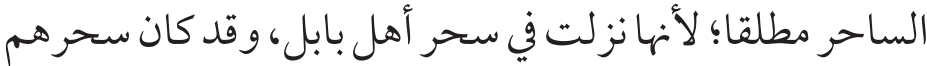

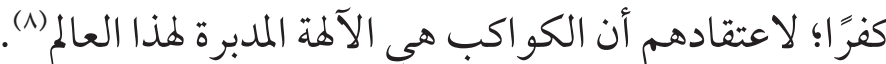

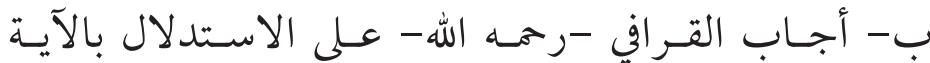

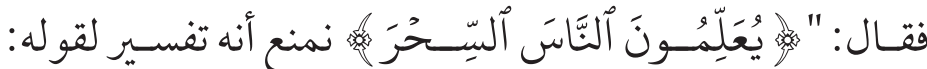

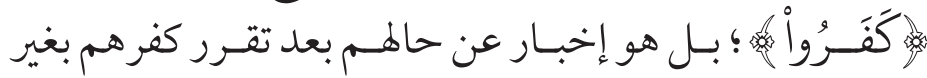

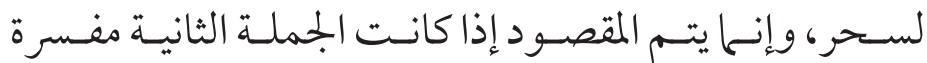

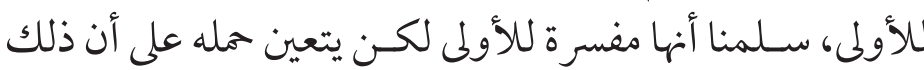

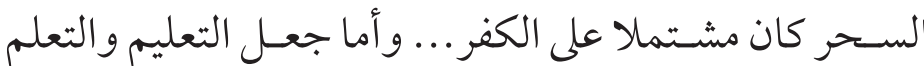
مطلقا كفر افخلاف القو اعد" (9).

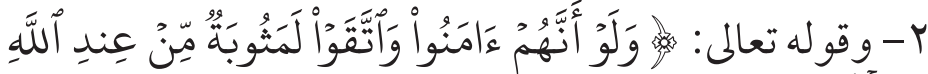

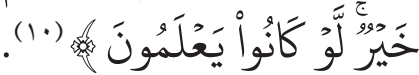

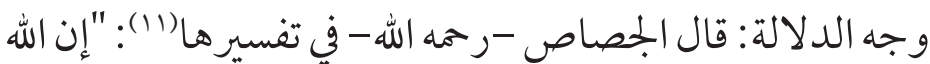

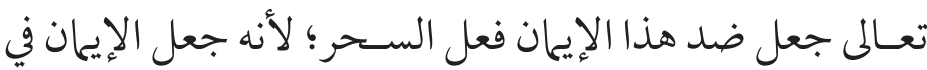

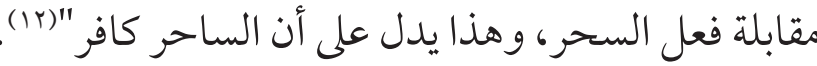

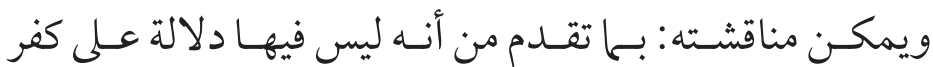

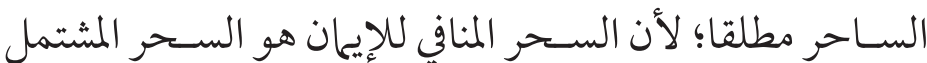

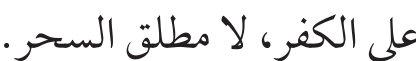

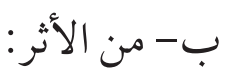

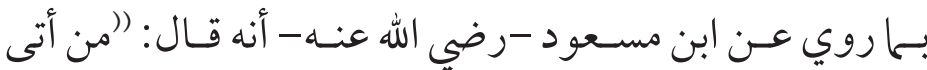

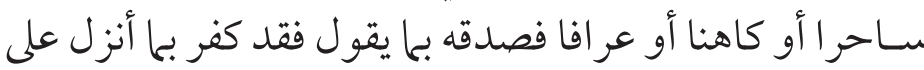

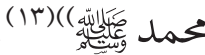
وجـهـ الدلالة: أن هـــا الأثر فيه دلالة على تكفير إتيان السـاحر

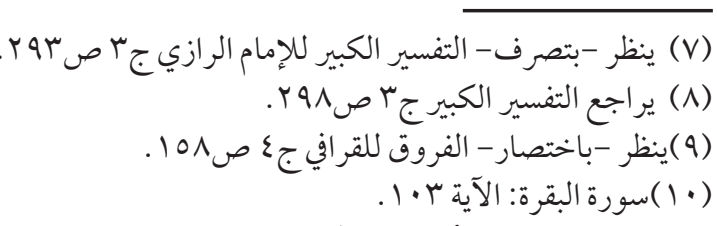

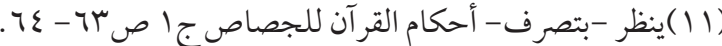

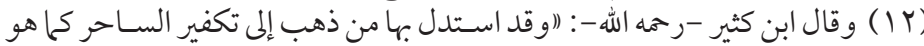

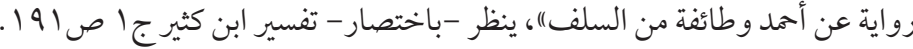

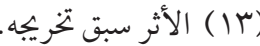

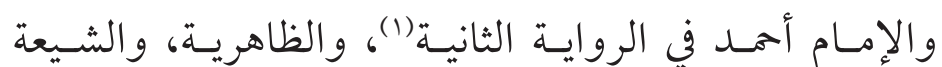
الإمامية) (r) (بامن

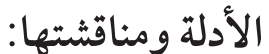

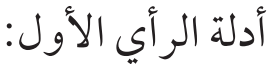
اسـتدل القائلون بتكفير السـاحر مطلقًا بالقـــــآن الكريم والأثر

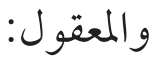

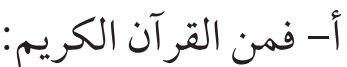

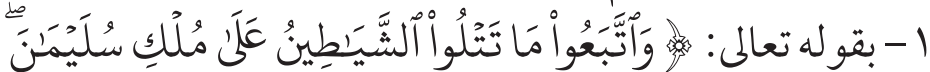

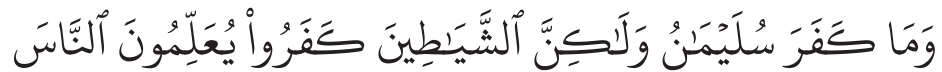

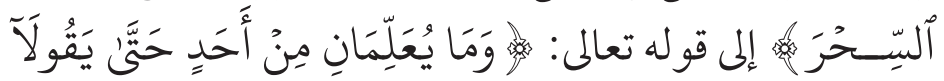

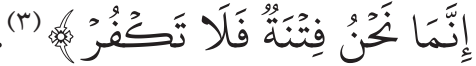

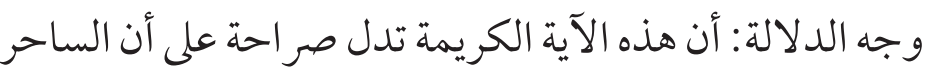

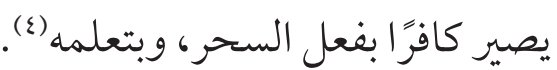

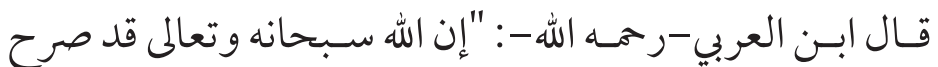

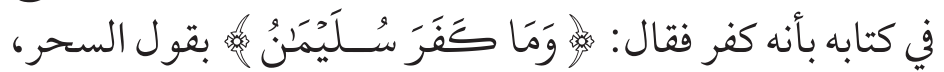

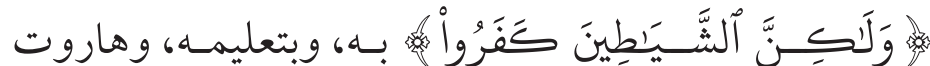

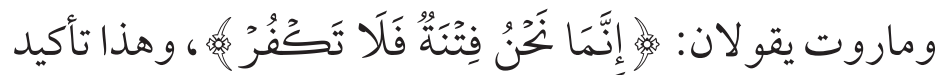

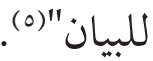

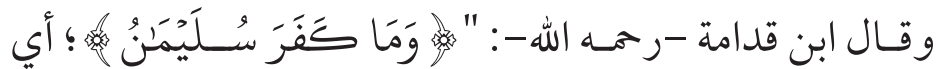

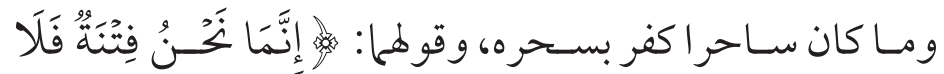

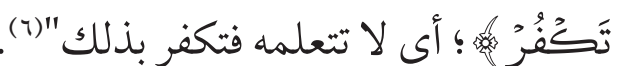

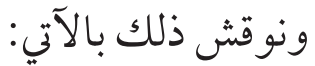

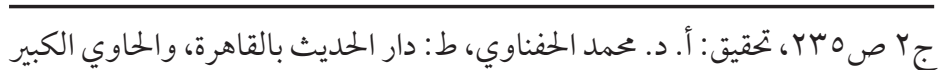

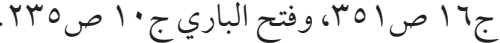

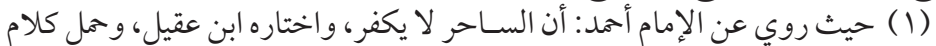

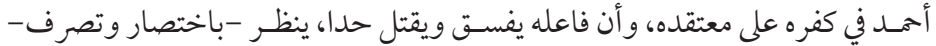

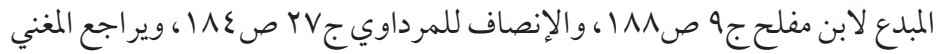

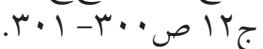

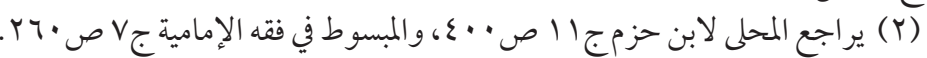

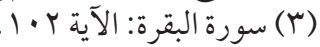

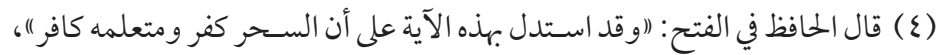

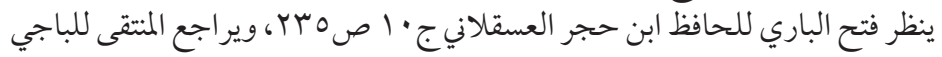

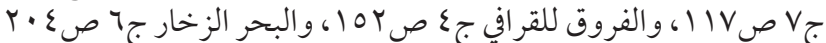

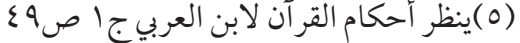

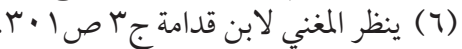


قال: قال رسـول الله

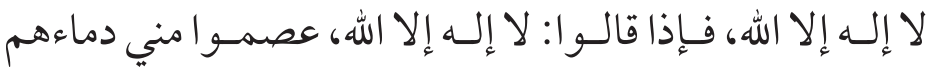
و وأمو الهم إلا بحقها وحسابهه على الله)(v).

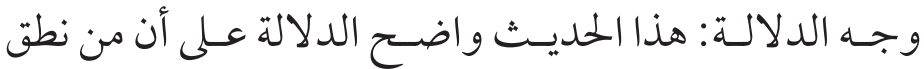

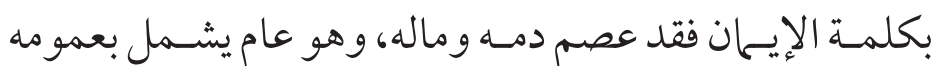

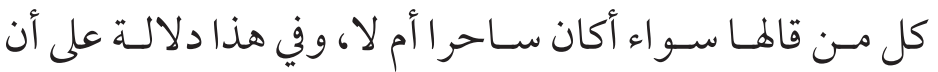

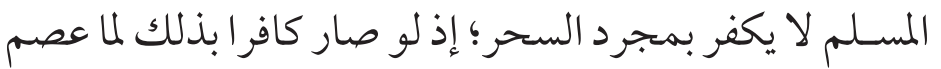

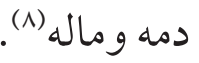

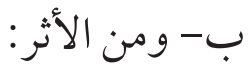

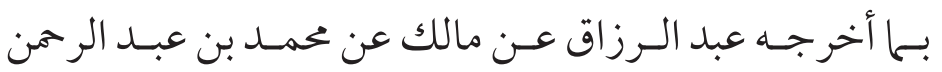

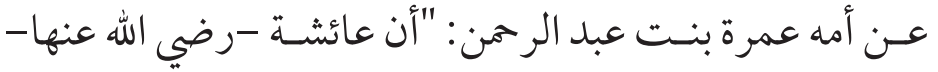

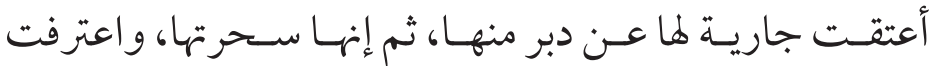

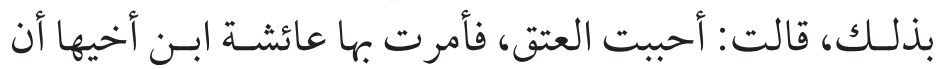

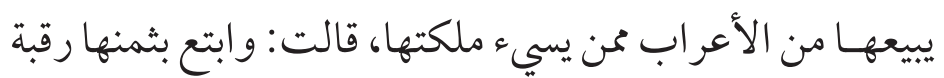

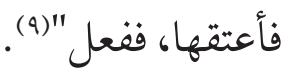
وجه الدلالة: أن هذا الأثر يدل على أن السـاحر لا يكفر بمجرد

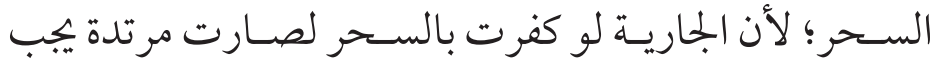

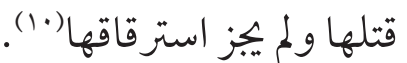

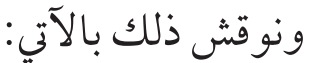
أو لا: بأن قول عائشـة -رضي الله عنها - قد خالفها فيه كثير من

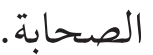
وثانيـا: بأنـه يحتمـل أن المدبـــة تابت من السـحر، فسـقط عنها

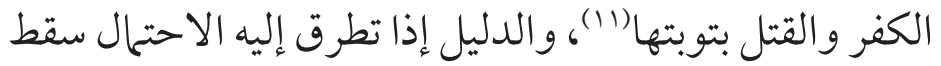

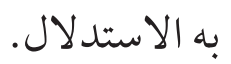

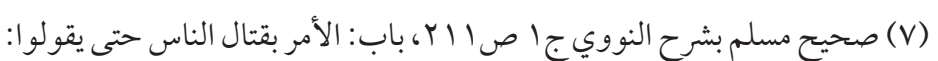

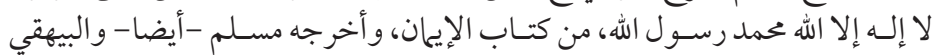

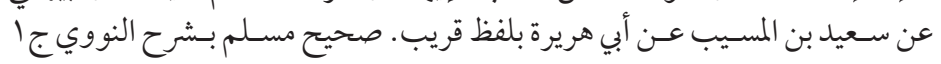

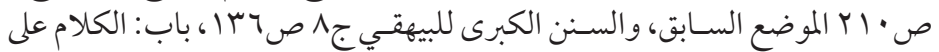

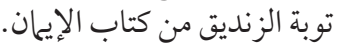

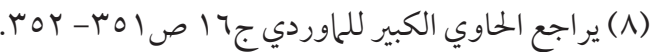

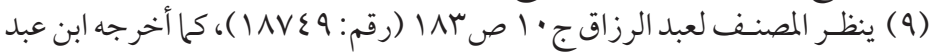

وتصديقه، سو اء كان ذلك لتعلم السحر أم لا (1)، وفي هذا دلالة على تكفير الساحر من باب أولى. ونوقش ذلك: بأنه محمول على من فعل ذلك مستحلا له له، أو بأنه

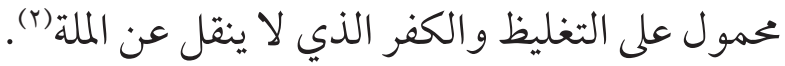
جـ--ومن المعقول: استدلوا بالآتي:

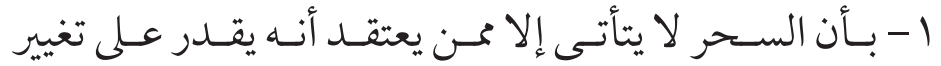

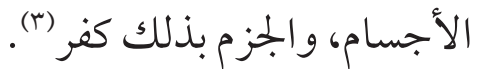
ونو قش ذلك: بأنه ليس كل سحر كفر ا؛ لأن السحرة قد يعتمدون

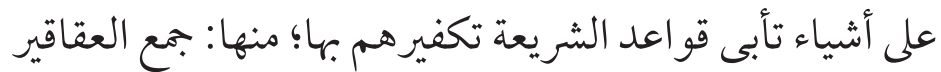

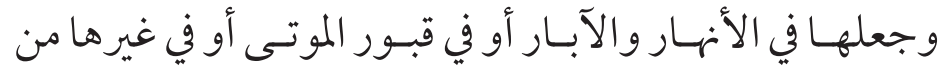

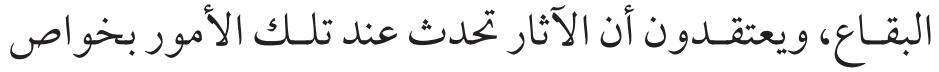

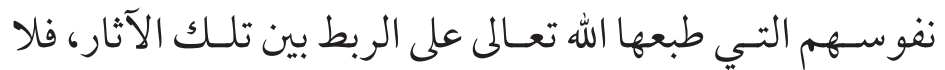

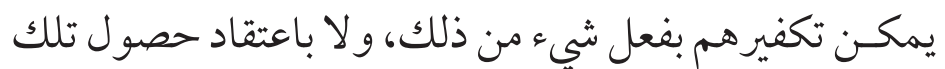
الآثار عند ذلك الفعل قياسـا على اعتقاد الأطباء حصول الأبعاد الآثار

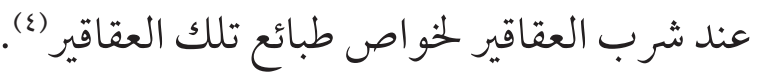

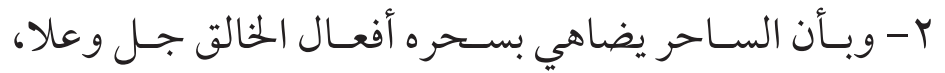

ومثل هذا كفر (0) ونوقـش ذلك: بـأن القـول بأنه يضاهي بسـحره أفــال الخالق

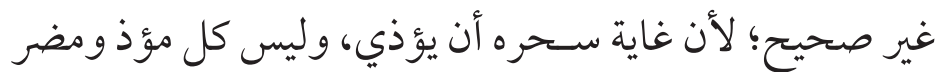

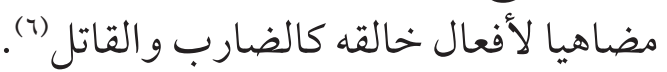

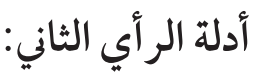
اسـتدل أصحاب الــ أي الثاني على ما ذهبو ا إليه بالسـنة والأثر

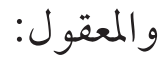

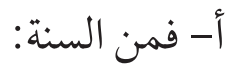
بما رواه مسلم من حديث جابر بن عبد الله -رضي الله عنها - أنه

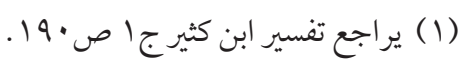

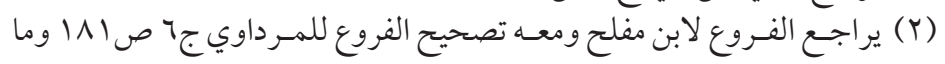
بعدها.

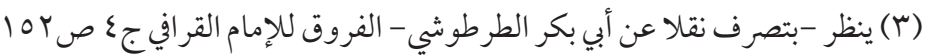
وما بعلها.

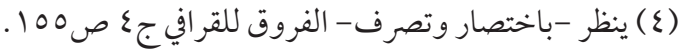

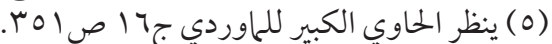

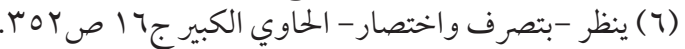


تعالى، فهذا مذهب الصابئة، وهو كفر صريح لا سـيها إن صرح

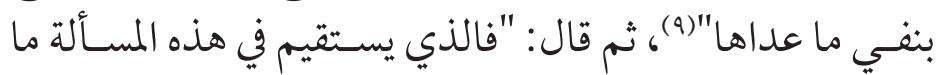

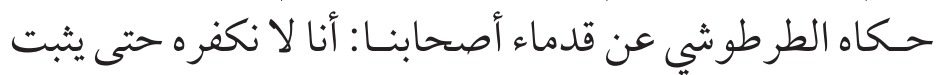

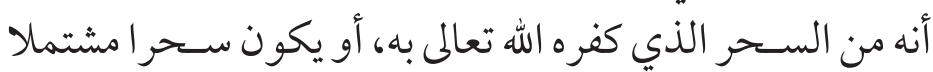
على كفر كما قال الشافعي" (·.).

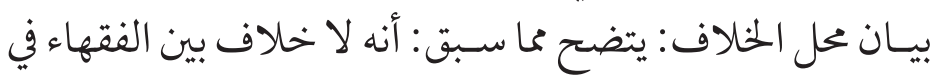

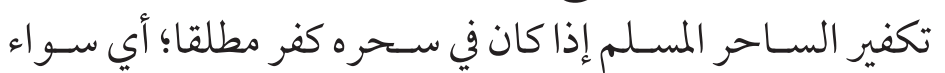

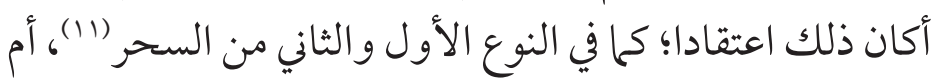

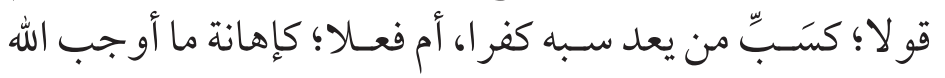

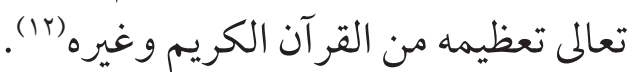

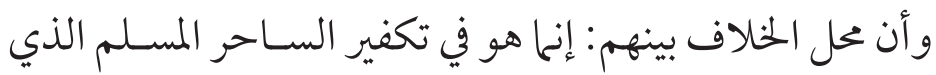

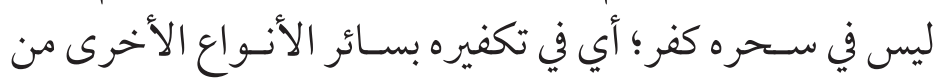

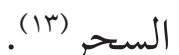

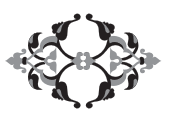

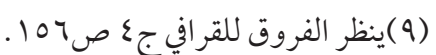

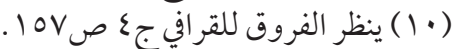

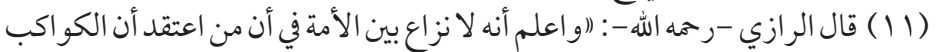

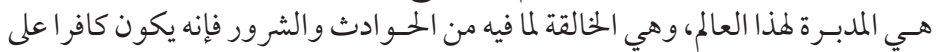

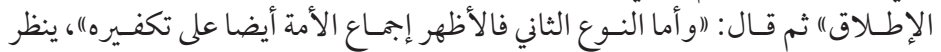

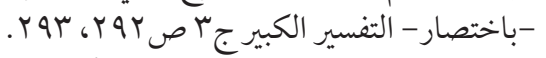

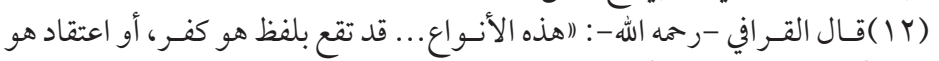

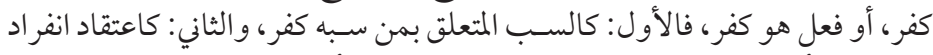

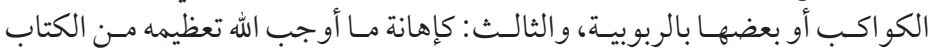

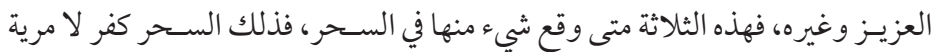

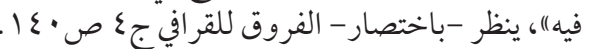

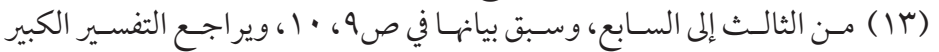

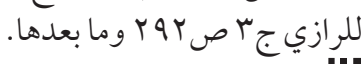

ج- - ومن المعقول: استدلو ا بما يأتي:

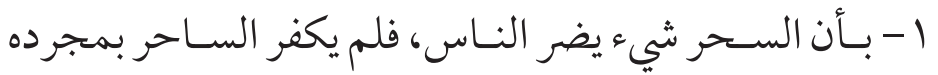
قياسا على أذاهم ")

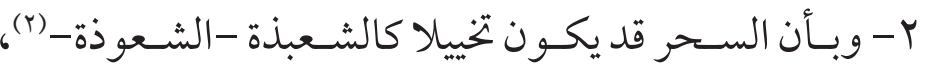

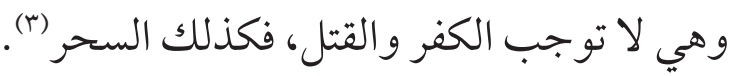

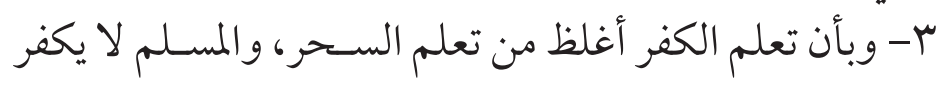

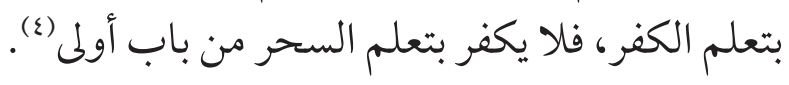

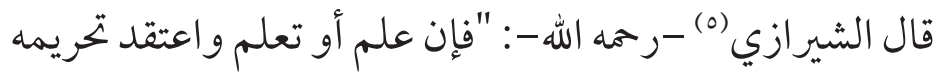

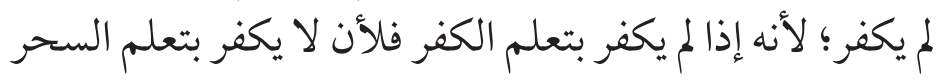

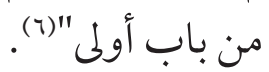

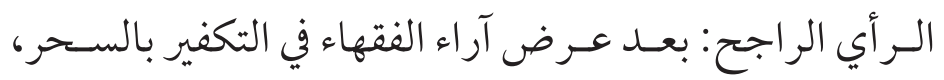

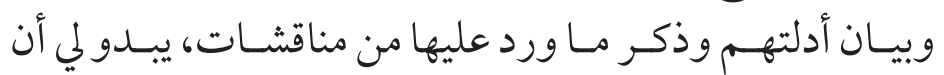

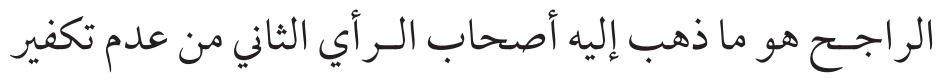

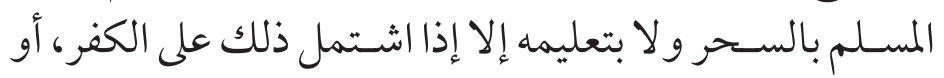

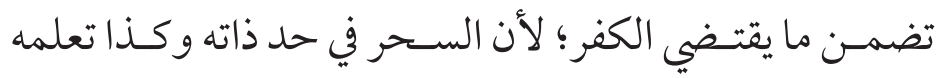

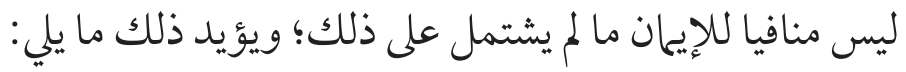

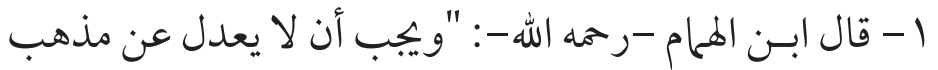

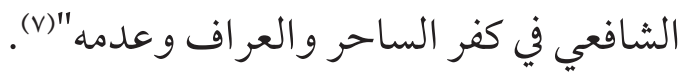

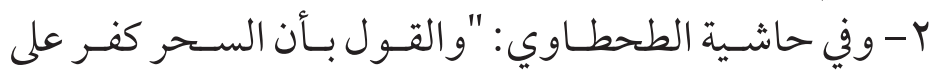

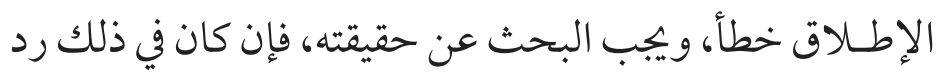

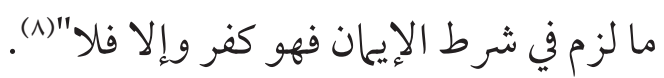

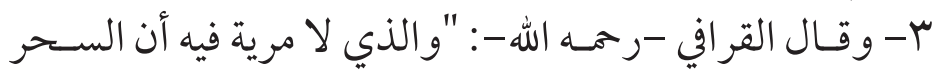

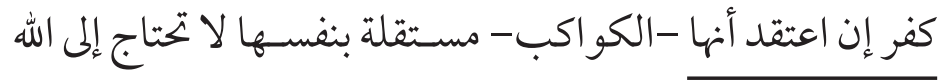

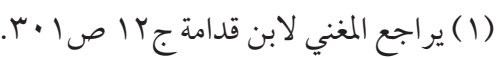

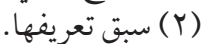

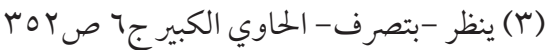

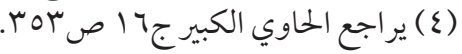

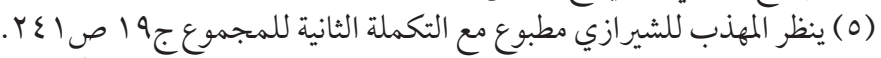

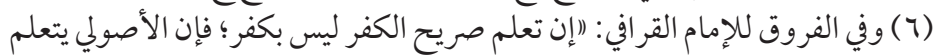

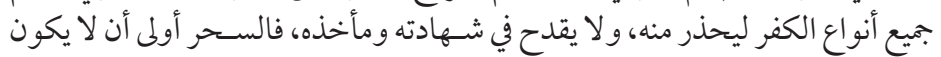

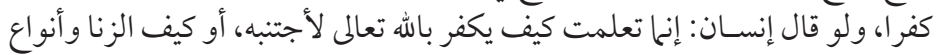

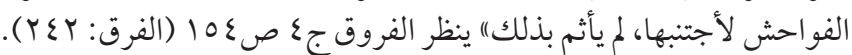

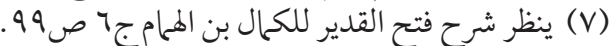

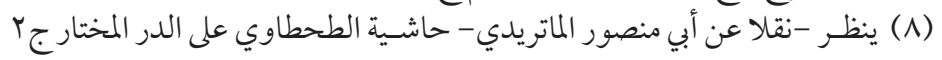
. 
r - أو بشهادة شاهدين على أنه ساحر (T)

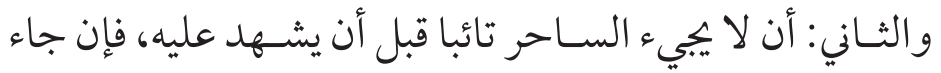

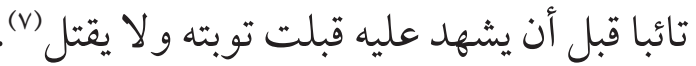

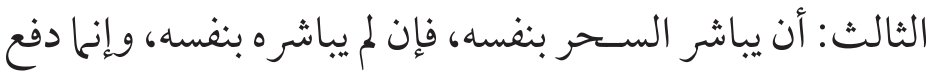

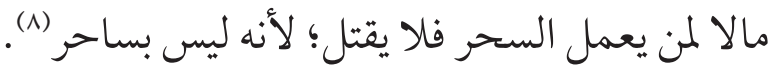

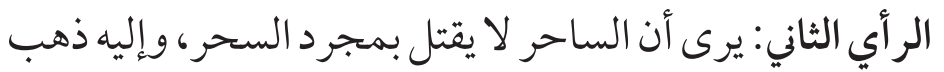

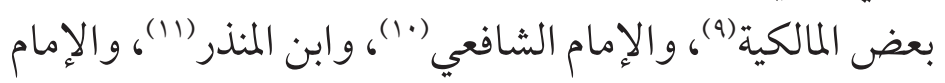

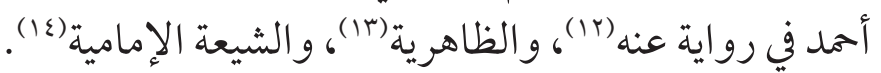
ولا يقتل الساحر عندهم إلا في حالتين:

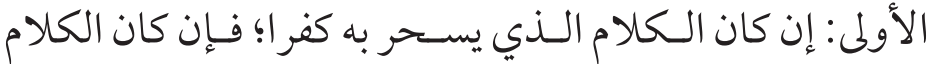
الذي يسحر به ليس كفر ا فلا يقتل (10).

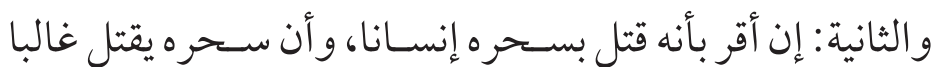

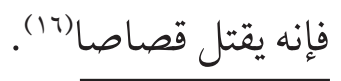

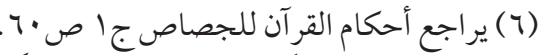

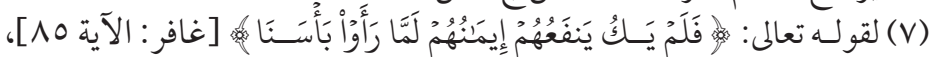

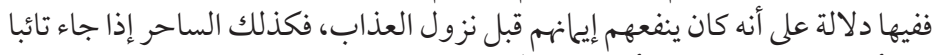

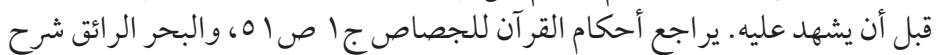

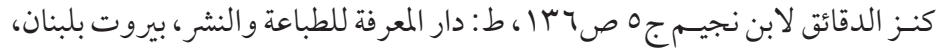

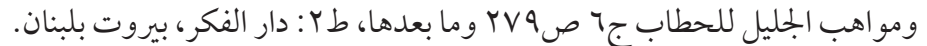

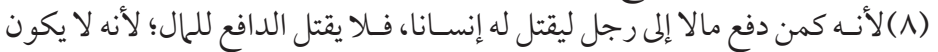

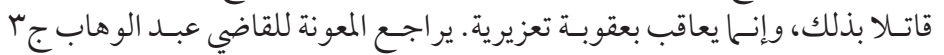

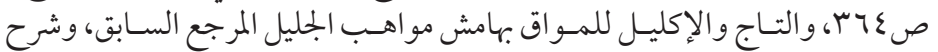

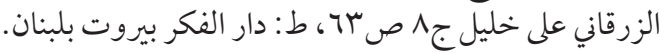

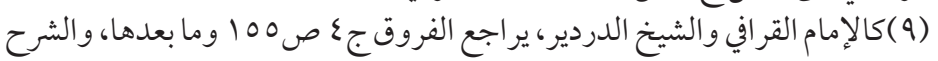

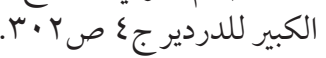

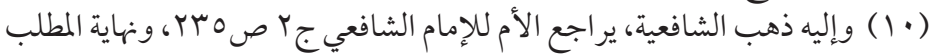

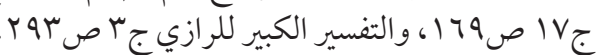

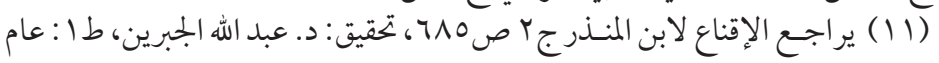

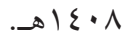

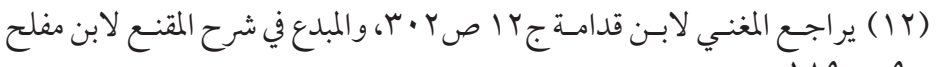

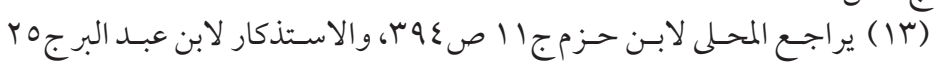
ص صنr

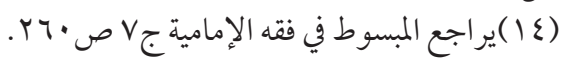

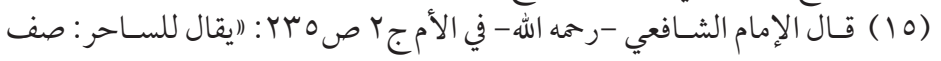

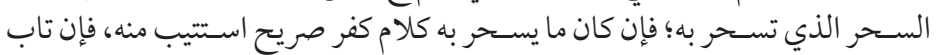

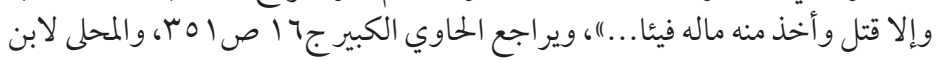
حزم والمبسوط في فقه الإمامية المرجعان السابقان. ( ا 1 ) ولا يسقط القصاص إلا أن يرضى أولياء المقتول بأخذ الدية فتكون حالَّة في مال

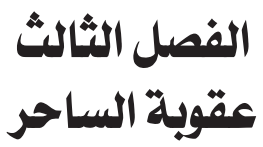

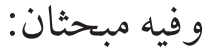

\section{عقوبة الساحر المسلم}

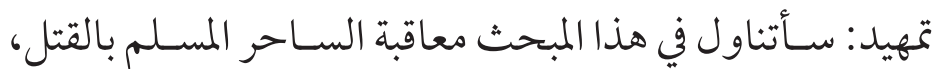

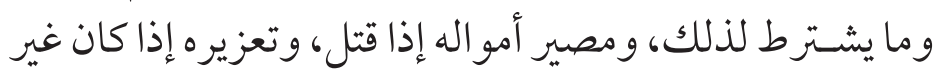
مستحق للقتل، وذلك في أربعة مطالب: المطلب الأول

\section{معاقبـة الساحر المسلمم بالقتل المسل}

اختلف الفقهاء في السـاحر المسـلم هل يعاقـب بالقتل مطلقا أم

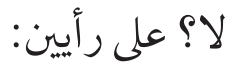

الـرأي الأول: يرى أنه يقتل بمجرد السـحر، وإليه ذهب جمهور

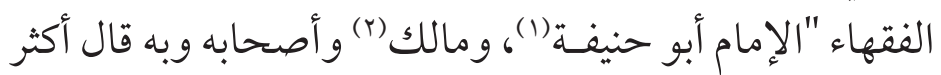

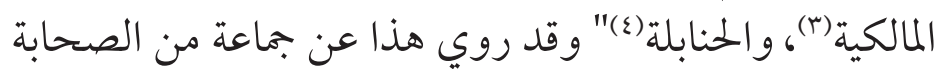
و التابعين رضو ان الله عليهم (0).

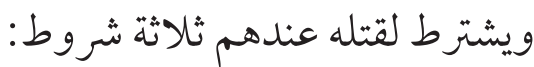

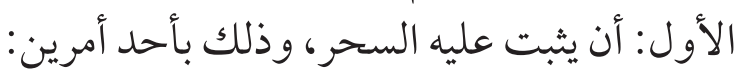
1 - (باقر اره بأنه ساحر.

(1) وإليه ذهـب الحنفية، يراجع أحكام القر آن للجصاصج اص • 7، وشرح فتح

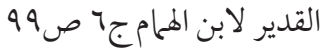

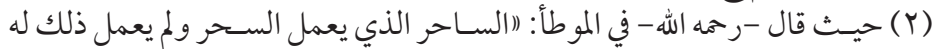

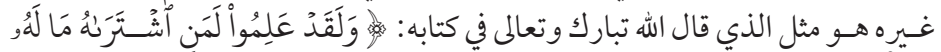

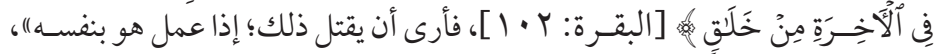

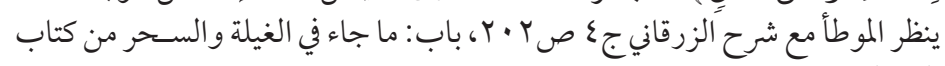

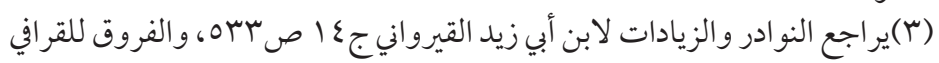

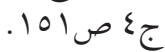

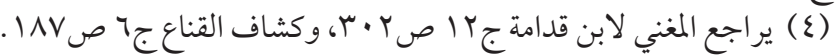

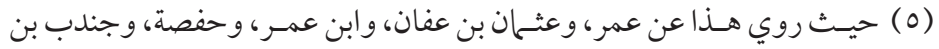

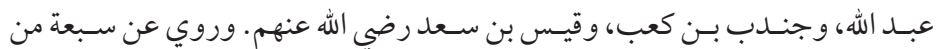

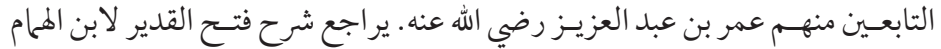

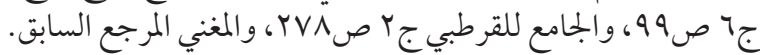




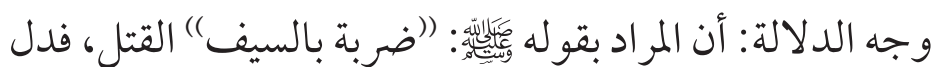

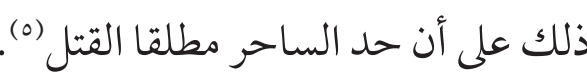

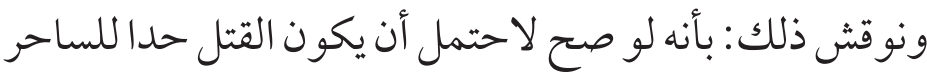

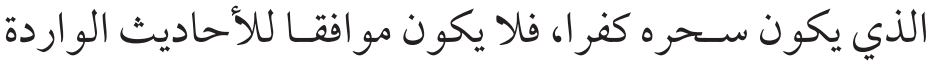

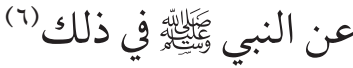

$$
\begin{aligned}
& \text { ج-ومن الأثر: }
\end{aligned}
$$

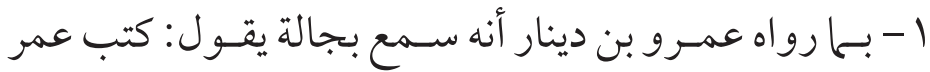

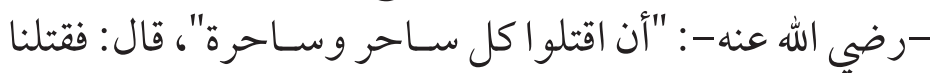

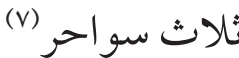

وجـه الدلالـة: أن هذا الأثر واضح الدلالة على قتل كل سـاحر وساحرة مطلقا؛ أي سو اء أكان السحر مشتملا على كفر أم لا.

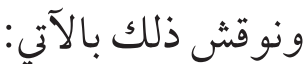

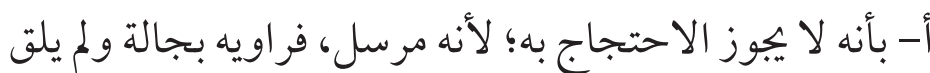
عمر رضي الله عنه (1).

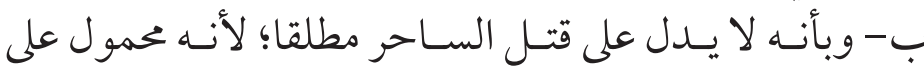
السحر الذي فيه كفر (9).

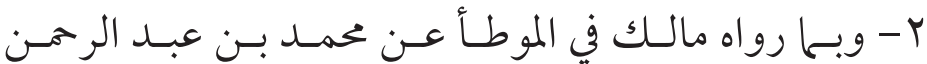

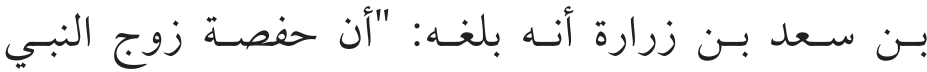

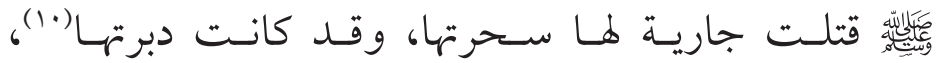

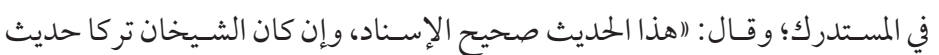

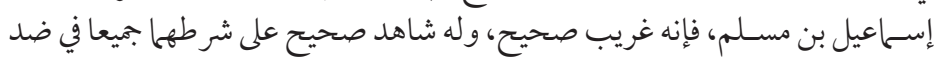

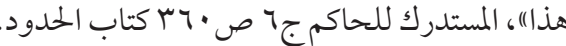

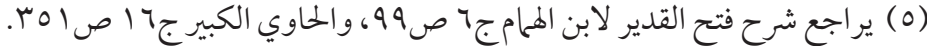

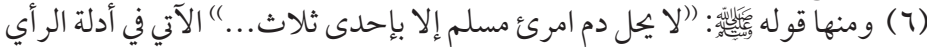

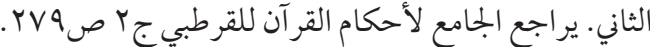

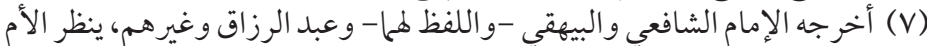

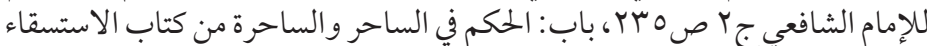

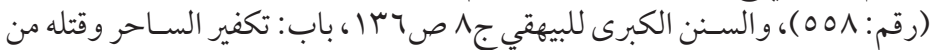

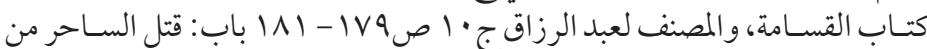

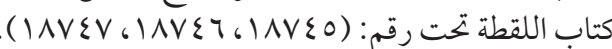

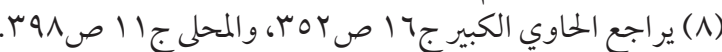

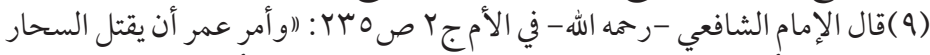

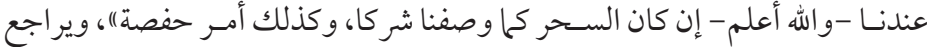

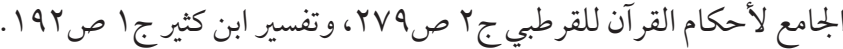

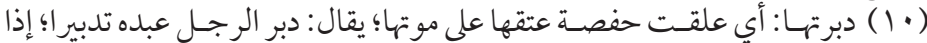

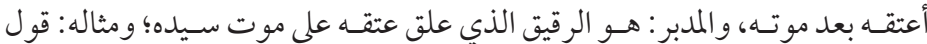

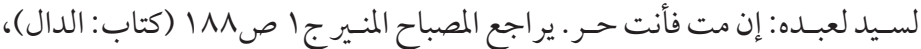

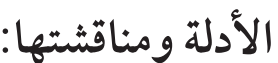

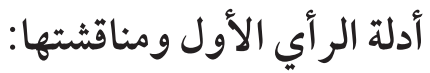
اسـتدل القائلون بقتل السـاحر مطلقا من القر آن الكريم والسنة

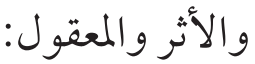

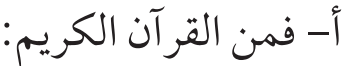

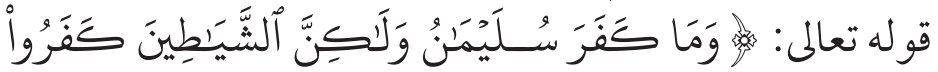

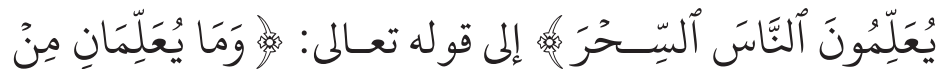

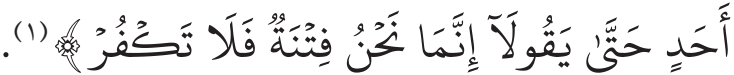

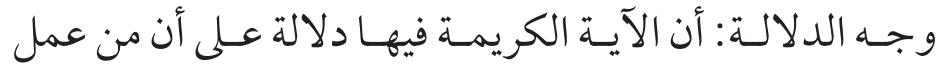
السحر وعلمه فقد كفر، و الكافر يجب قتله (r).

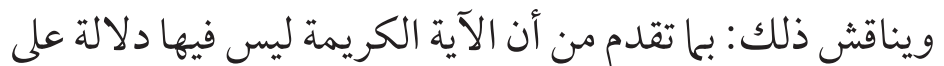

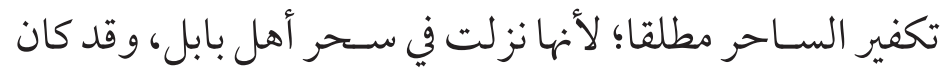

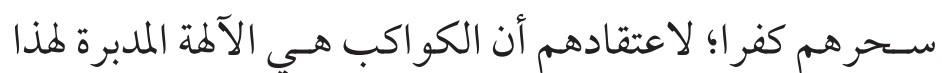

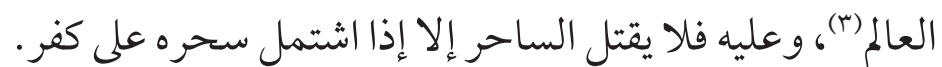

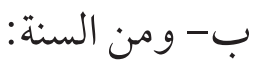

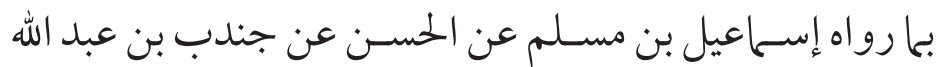

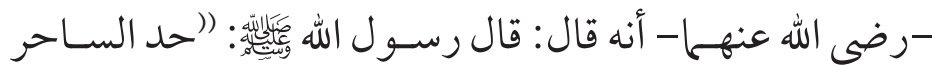

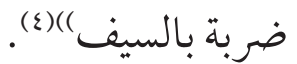

وتجدر الإشارة: إلى أن الساحر لو قتل بسحره فإنه يأخذ حكم الجناية على النفس، وفيها

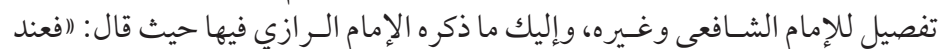

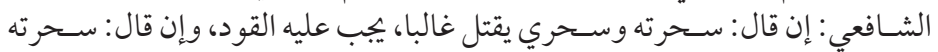

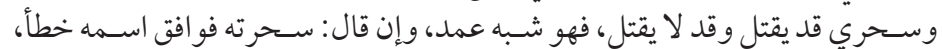

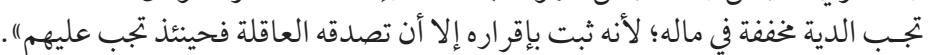

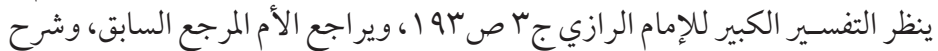

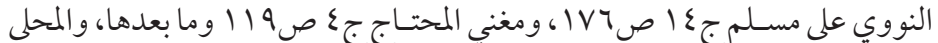

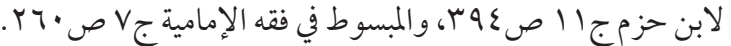

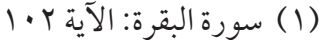

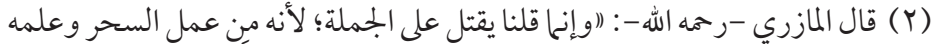

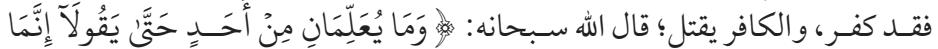

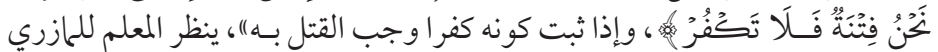

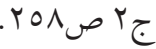

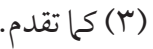

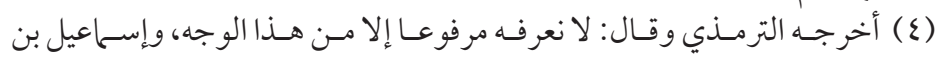

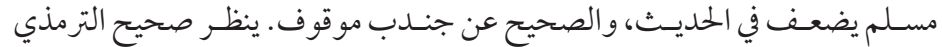

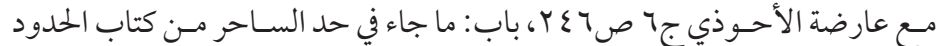

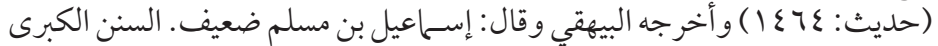

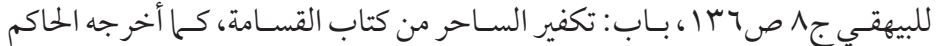


ونوقش ذلك: بأن قولهم: "إنه مضاه لأفعال الخالق "غير مسلم؟

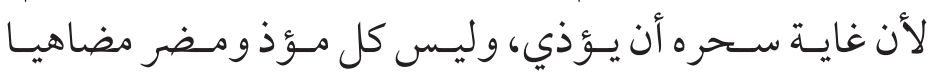
لأفعال خالقه كالضارب و القان القاتل (9)

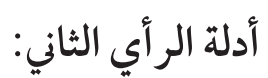
اسـتدل القائلمون بـأن السـاحر لا يقتل بمجرد السـحر بالسـنة والأثر والمعقول:

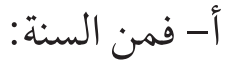

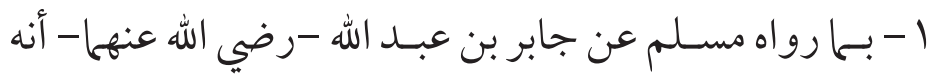

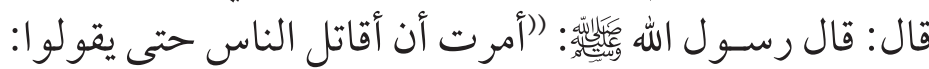

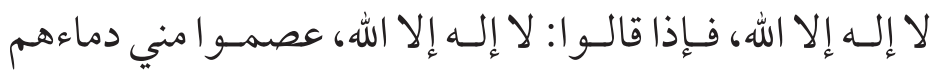
و أمو الهم إلا بحقها وحسابهم على الله)(·.).

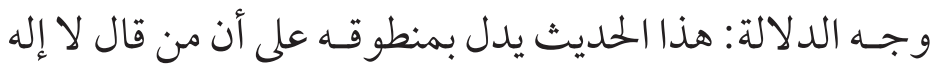

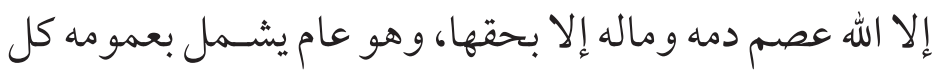
من قالها من ساحر وغير ساحر (11).

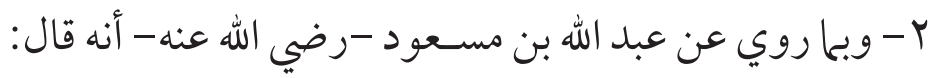

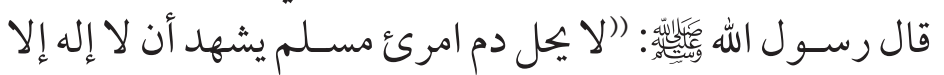

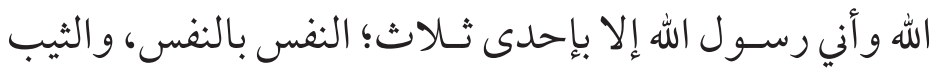

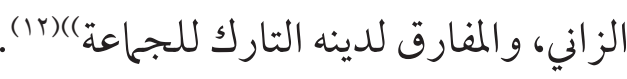

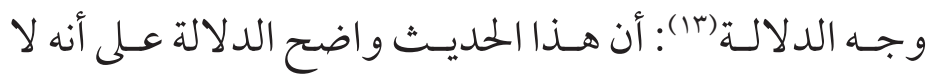

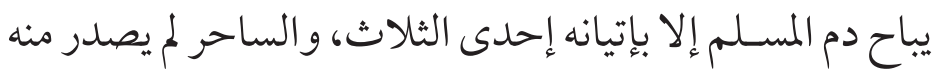

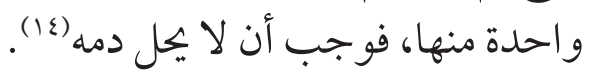

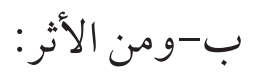
(9) (19) ينظر -بتصرف- الحاوي الكبير المرجع السابق.

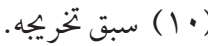

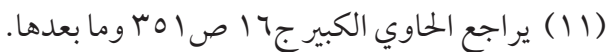

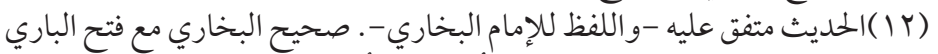

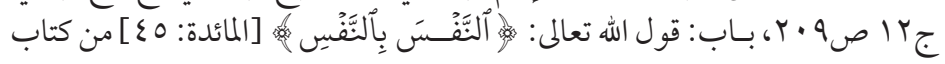

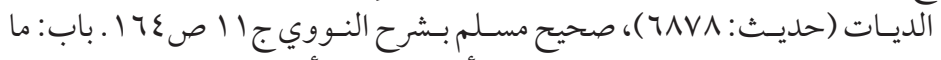

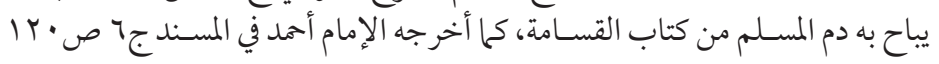

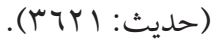

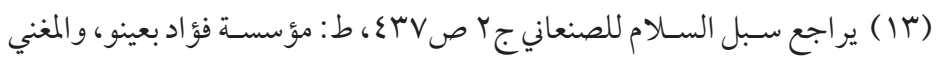

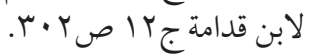

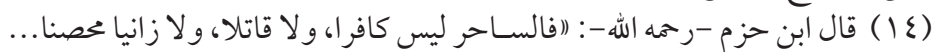

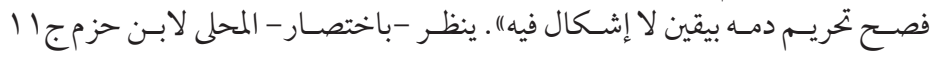

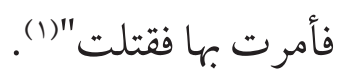

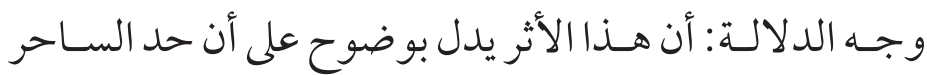

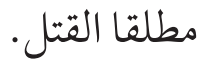

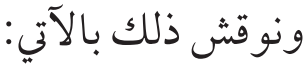

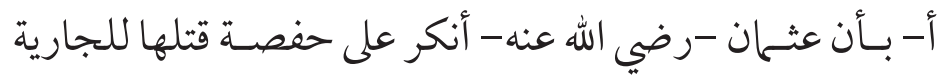

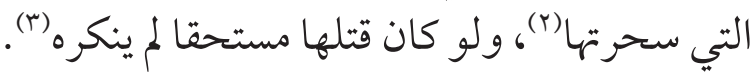

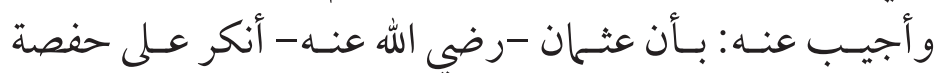

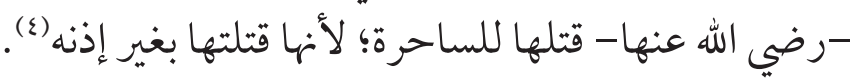

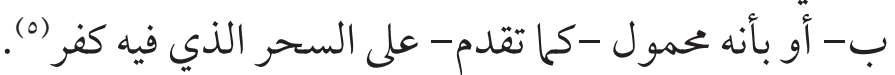

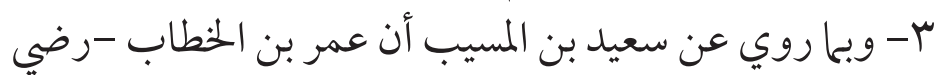

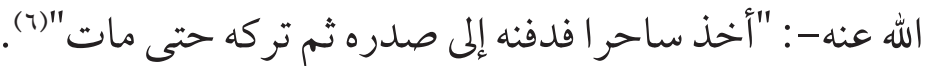

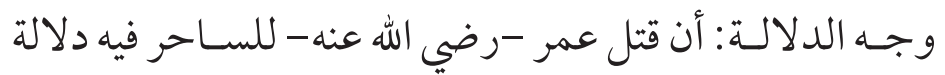

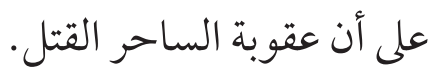

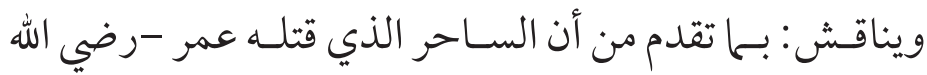

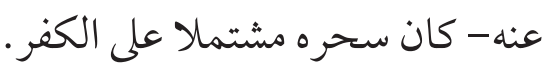

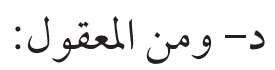

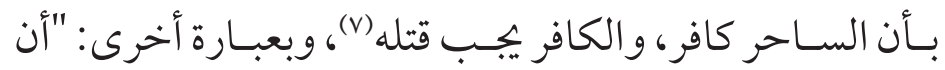

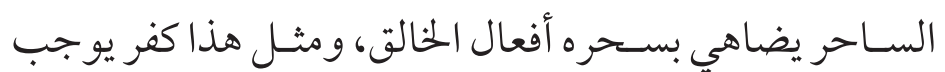

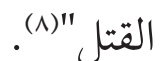

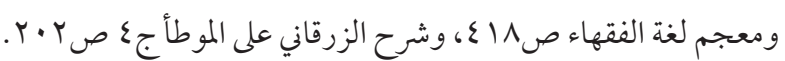

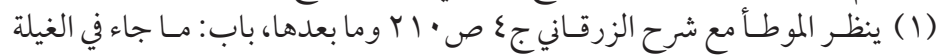

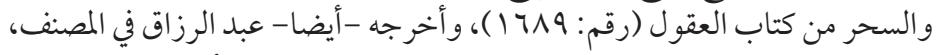

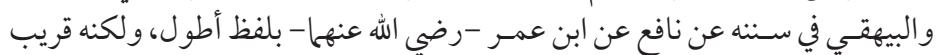

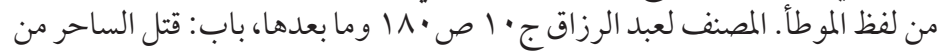

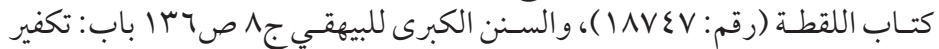
الساحر من كتاب القسامة.

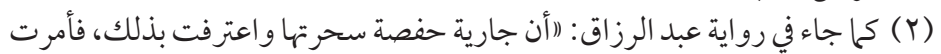

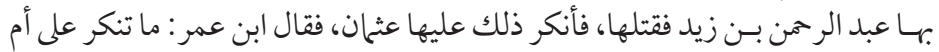

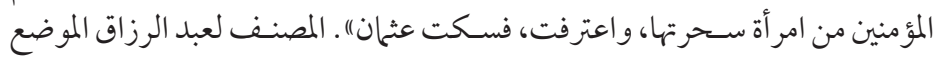

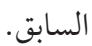

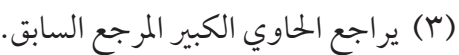

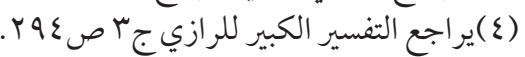

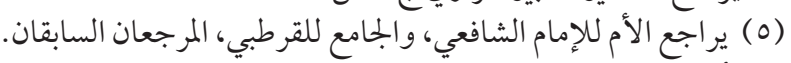

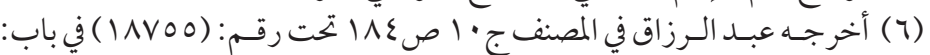
قتل الساحر من كتاب اللقطة.

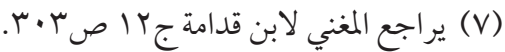

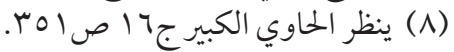


والراجح هو ما ذهب إليه أصحاب الر أي الثاني من أن السـاحر

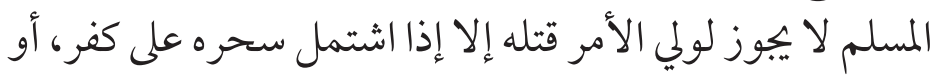
ثبت أنه قتل بسحره بـا يقتل غالبا؛ للآتي: أولا: لقوة أدلتهم التي استدلو ابها.

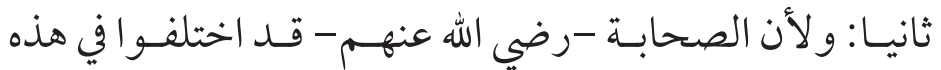

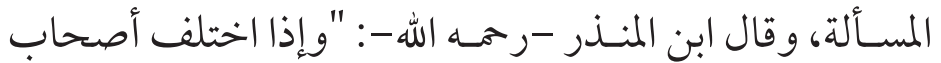

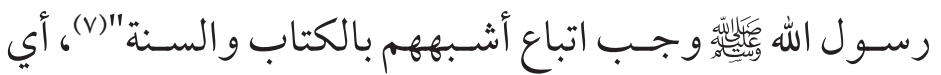

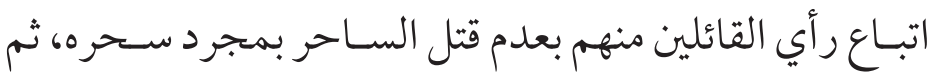
حمل -رحمه الله - الأدلة في قتل السـاحر على الساحر الذي يكفر السترد

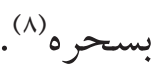
ثالثا: و لأن دماء المسلمين محظورة لا تستباح إلا بيقين، ولا يقين مع الاختلاف (a) ولان رابعـا: ولأن في الأخذ بهذا الـرأي، وحمل أدلة الر أي الأول على إلى السـاحر الذي يكفر بسحره -كما قال ابن المنذر وغيره- إعمال

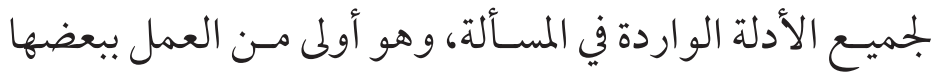

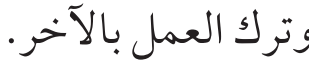

\section{المطلب الثاني \\ هل يشترط لمعاقبة السأحر المسلم

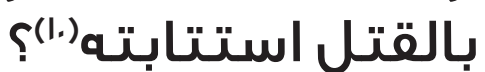

هل يشـترط لقتل الساحر المسـلم الذي يكفر بسحره استتابته أم الم المعاه

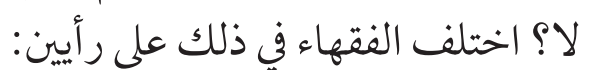

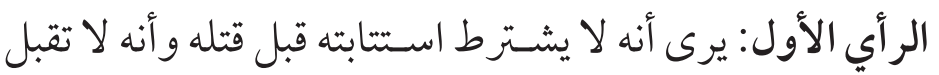

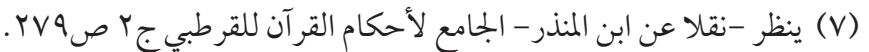

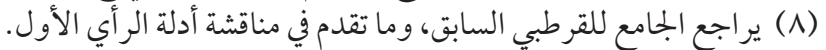

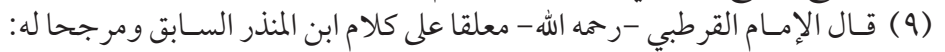

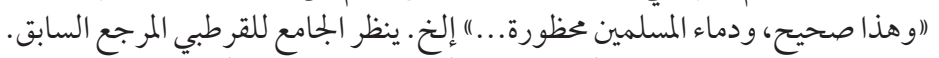

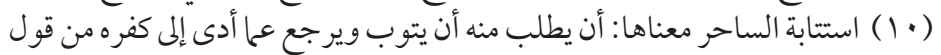

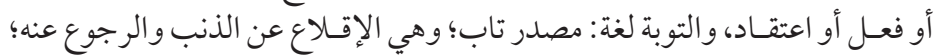

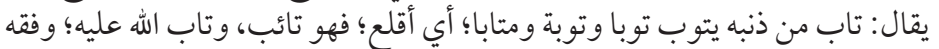

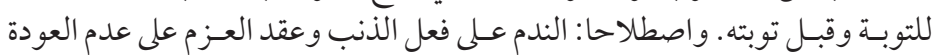

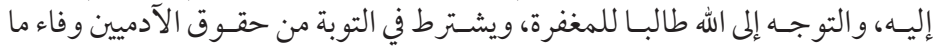

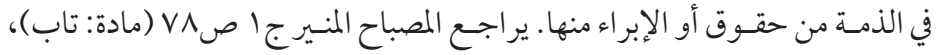

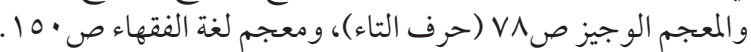

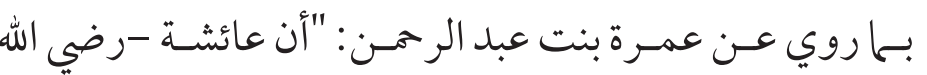

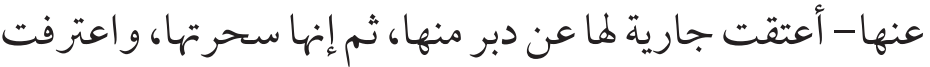

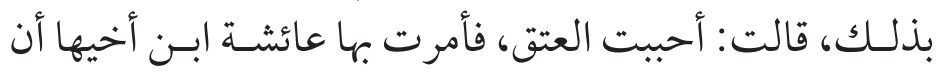

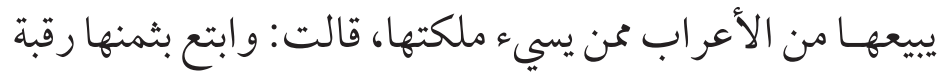

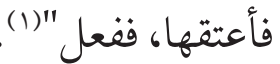
وجـه الدلالة (r): أن بيع عائشــة -رضي الله عنها - للمدبرة التي

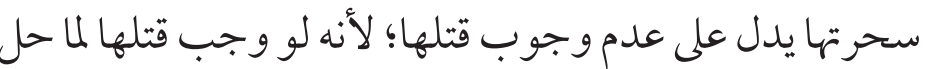
(r) ج -ومن المعقول: بأن الساحر المسلم لا يقتل قياساعلى الساحر

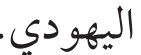

قـال الـرازي -رحمـهـ الله-()): "إن سـاحر اليهـود لا يقتل؛ لأنه

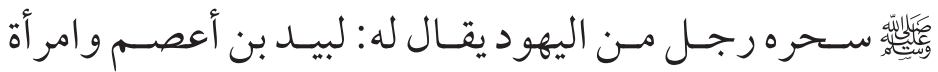

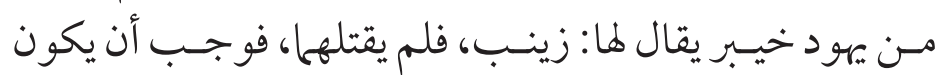

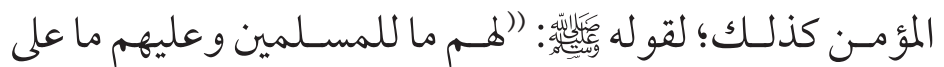

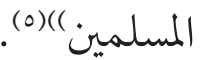

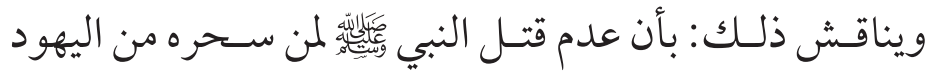

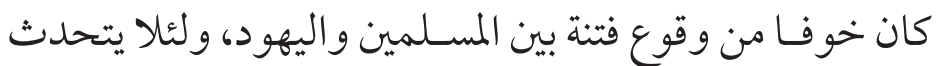

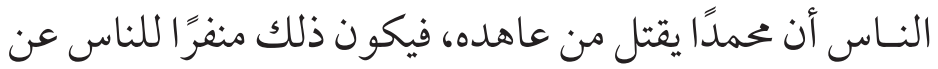

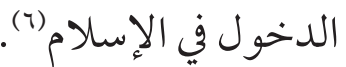
الـرأي الراجح: بعد ذكر آراء الفقهاء في معاقبة السـاحر المســم المبلم

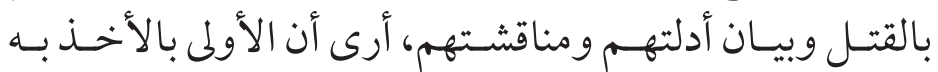

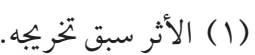

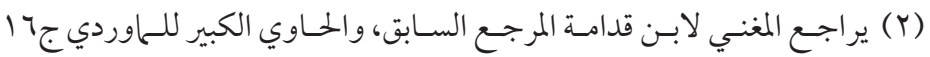

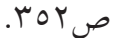
(r) قـال أبــو عمر بن عبد البر في الاسـتذكار: الوفيه أن السـاحر لا يقتل إذا كان عمله

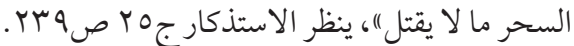

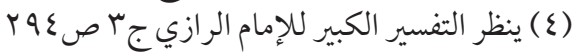

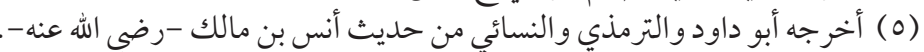

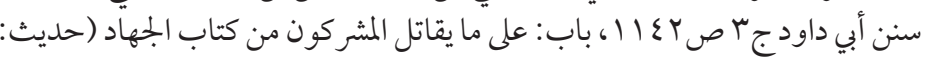

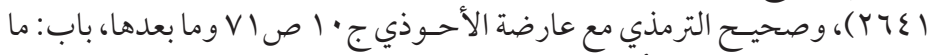

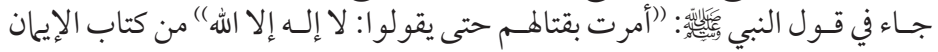

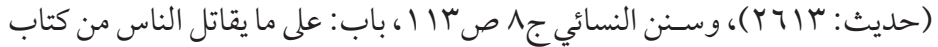

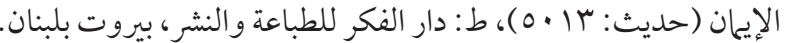

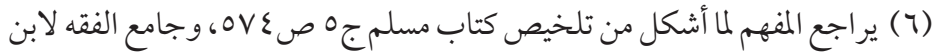

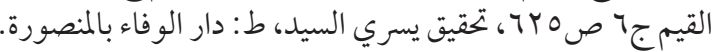


توبته إن تاب بعد ثبوت السحر عليه (1)، وإليه ذهب الحنفية(r)، والمعقول:

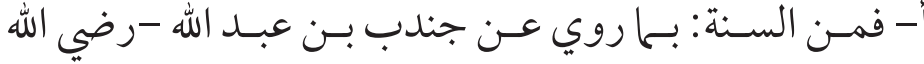
عنه) - أن رسول الله

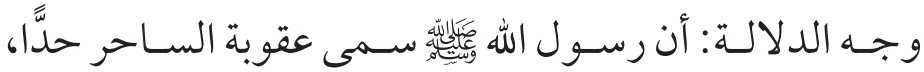
والحد بعد ثبوته لا يسقط بالتوبة (11).

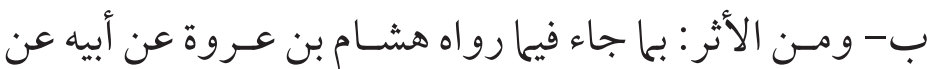

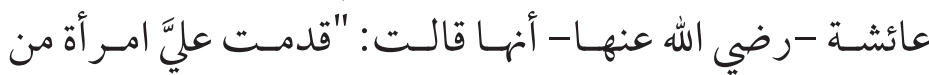

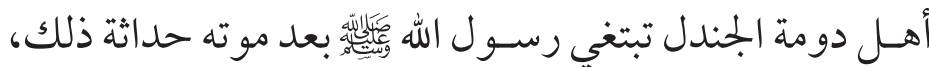

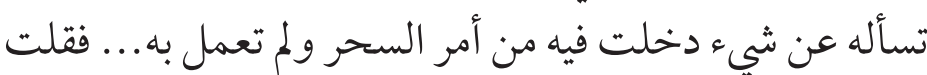

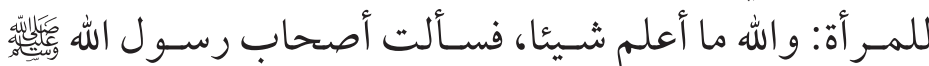

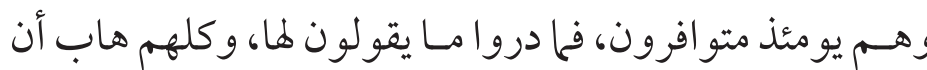

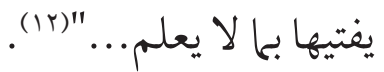
وجه الدلالة: أن هذا الأثر يدل على عدم جواز استتابة الساحر؛ لأنه لو جاز استتابته؛ لأفنى الصحابة الساحرة بأن لها توبة (بان).

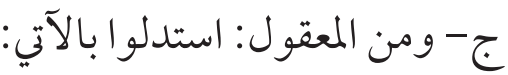

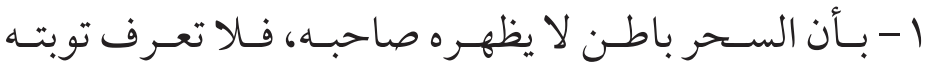

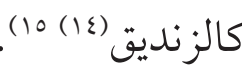

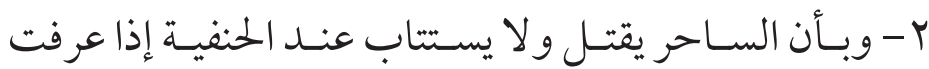

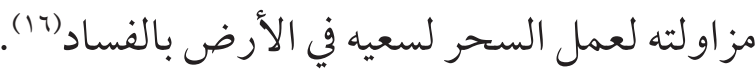

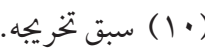

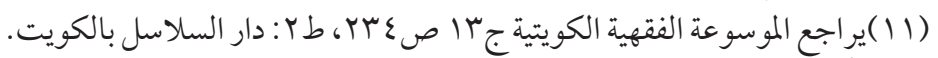

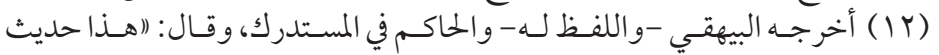

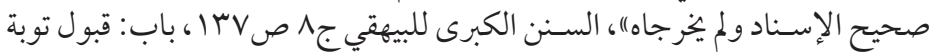

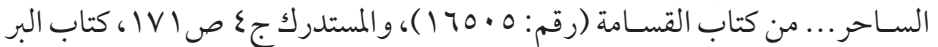

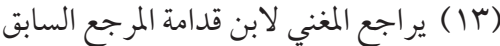

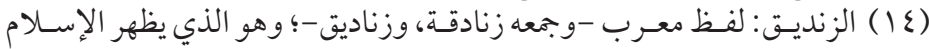

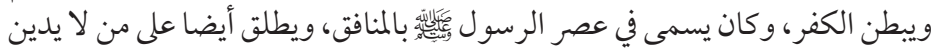

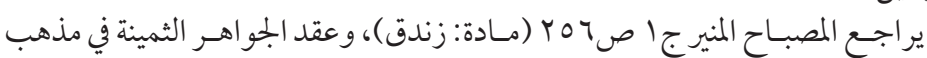

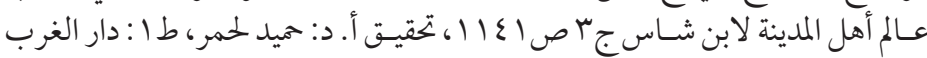

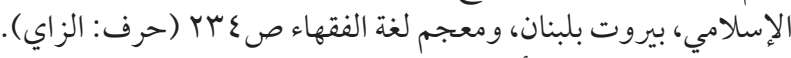

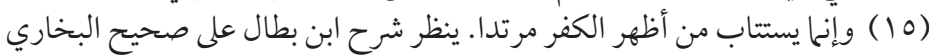

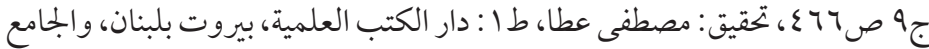

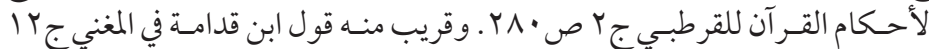

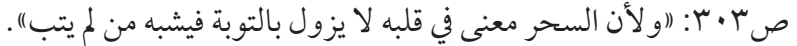

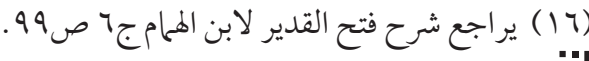

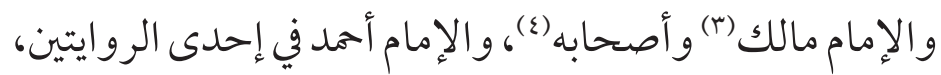

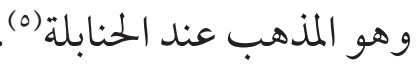

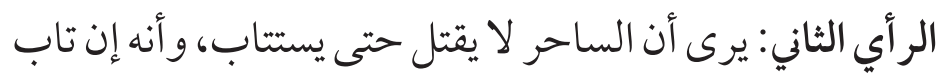

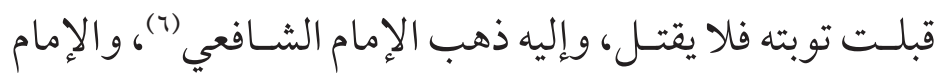

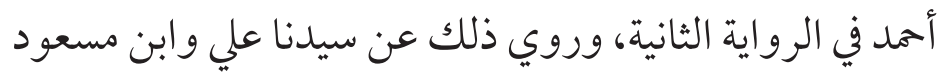

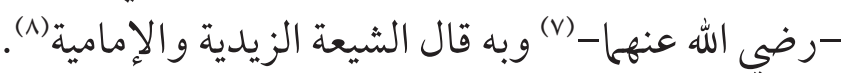

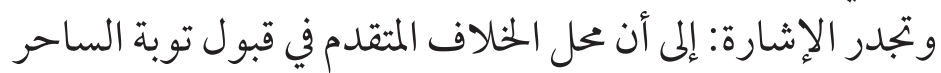

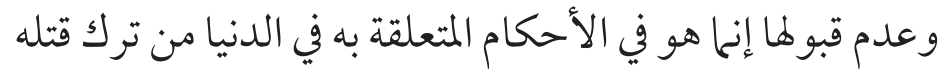

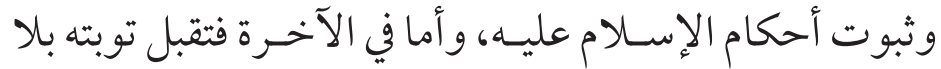

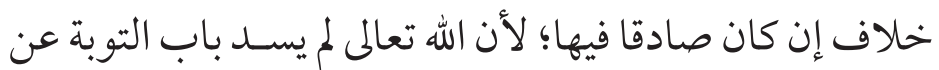
أحد من خلقه، ومن تاب إليه قبل توبته (9).

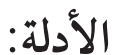

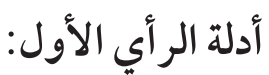

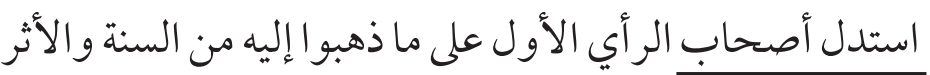

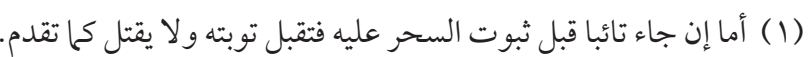

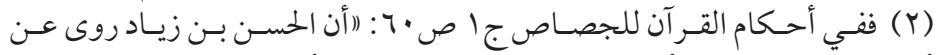

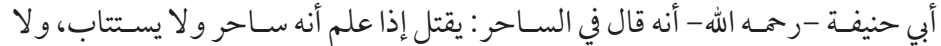

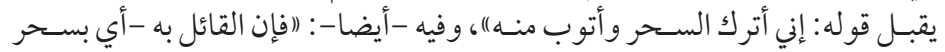

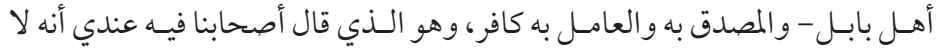

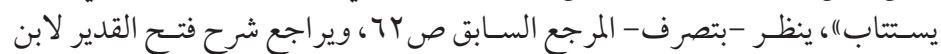

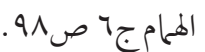

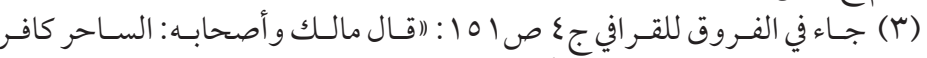

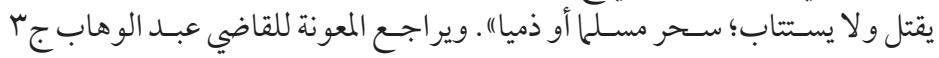

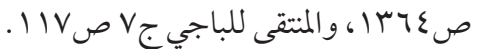

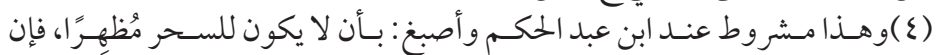

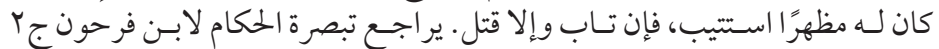
ص 197

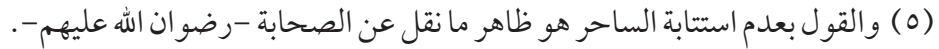

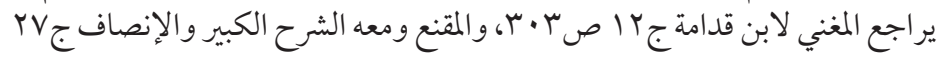

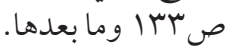

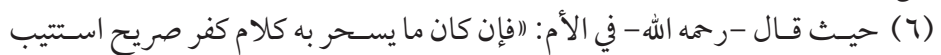

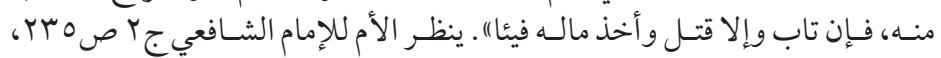

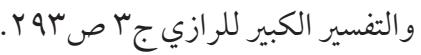

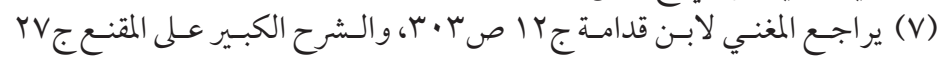
ص. (1)

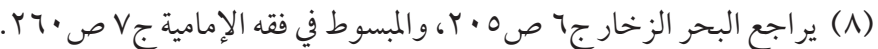

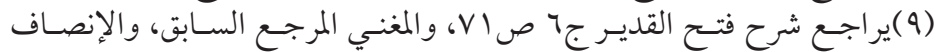

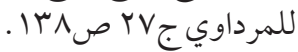




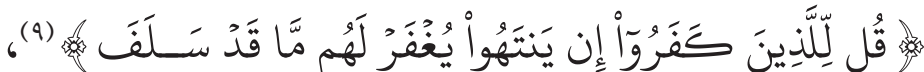

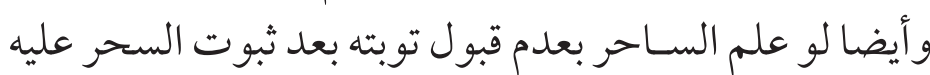

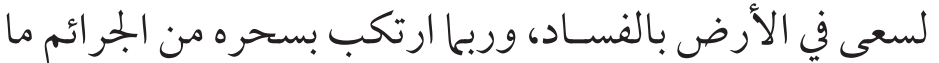
لا يعلمه إلا الله تعالى.

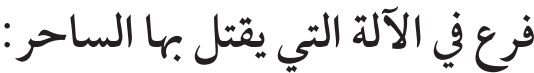

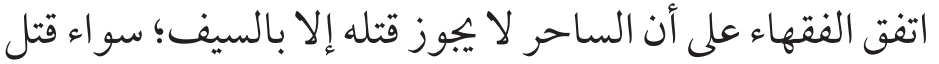

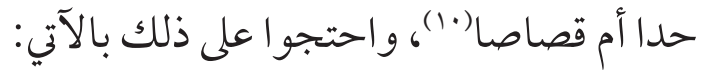
أ- من السنة:

بما روي عن جندب بن عبد الله -رضي الله عنهم)- أن رسول الله

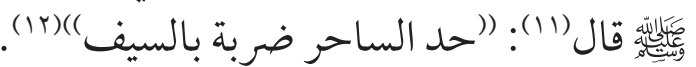

$$
\text { ب- ب-ومن المعقول: }
$$

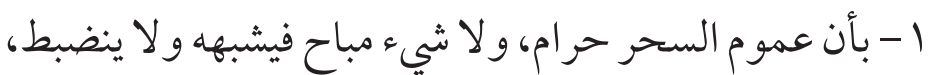
وتختلف تأثيراته (ri).

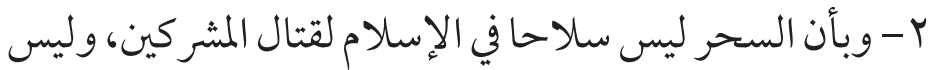
آلة قصاص، وليس له مثل (\&) (1).

\section{المطلب الثالث ميراث الساحر إذا قتل}

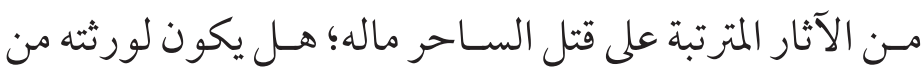

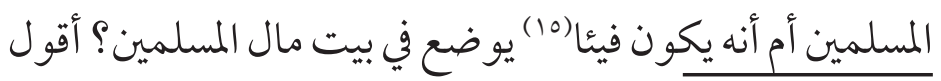

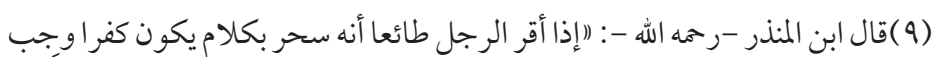

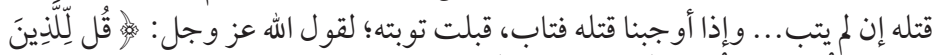

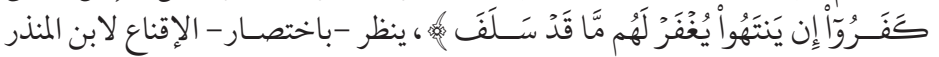

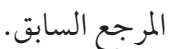

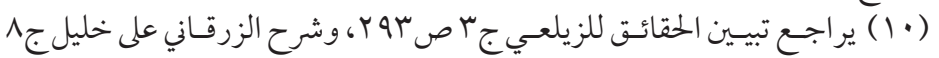

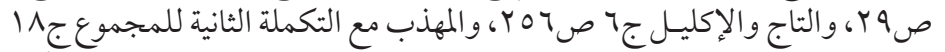

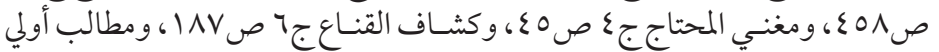

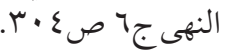
ذ) (Ir) (Ir) يراجع مغني المحتاج وكشاف القناع، المرجعان السابقان.

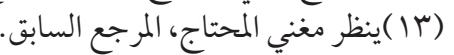

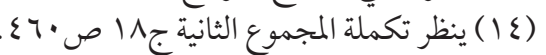

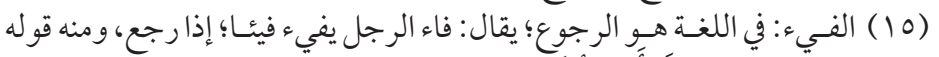

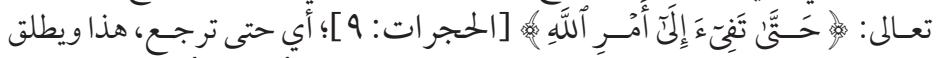

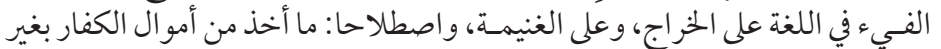

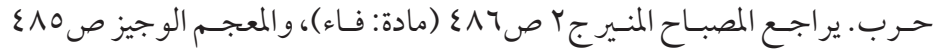

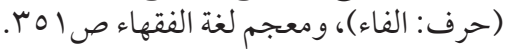

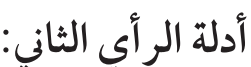
استدل القائلون باشتراط استتابة الساحر قبل قتله، وأنه إن تاب آلتاب تقبل توبته فلا يقتل بالقر آن الكريم والمعقول:

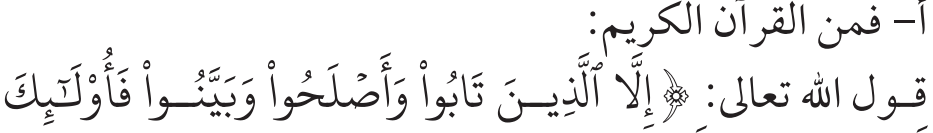

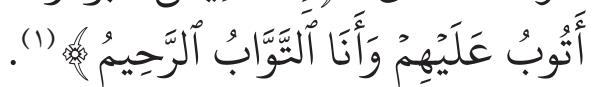

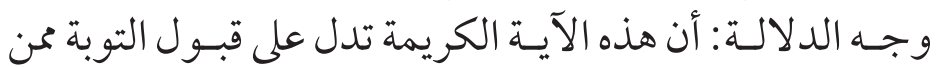

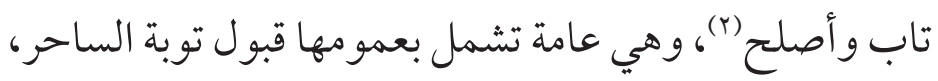

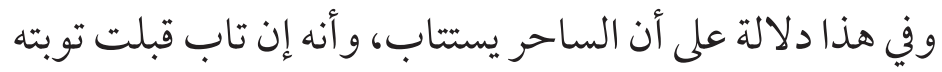
فلا يقتل (r). ب- بالب ومن المعقول: استدلوا بالآتي:

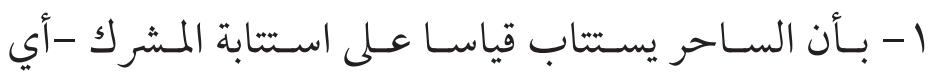

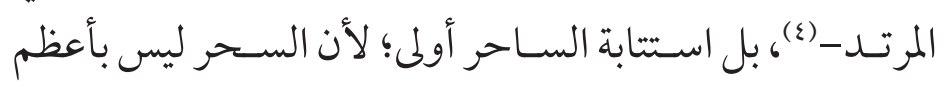

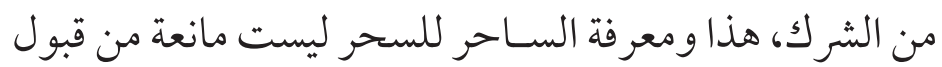

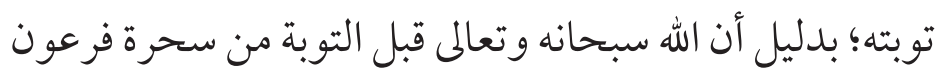
وجعلهم من أوليائه (o). ץ- وبأن الساحر لو كان كافر ا فأسلم صح إسلامه وتوبته، فإذاذا صحت التوبة منهم) صحت من أحدهما كالكفر (1).

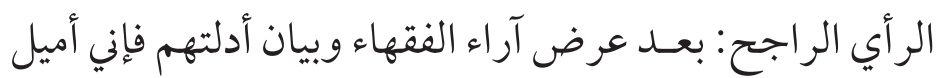

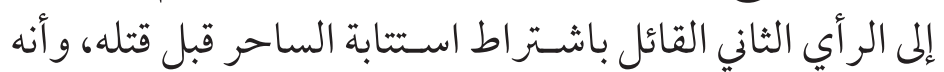

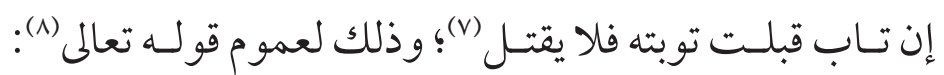

(1) سورة البقرة: الآية • 17.

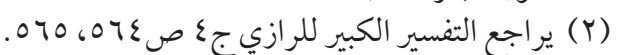

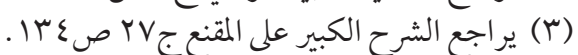

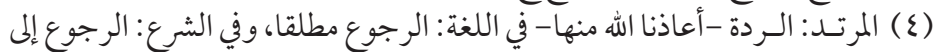

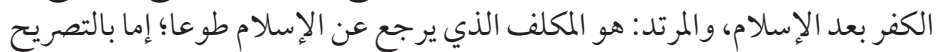

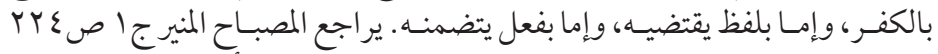

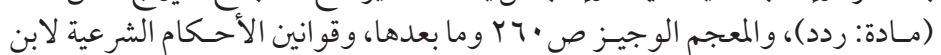

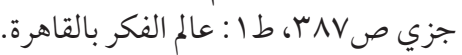

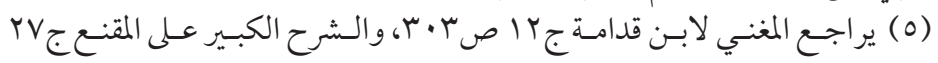
ص.

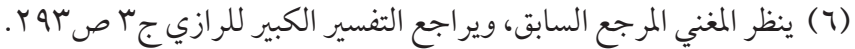

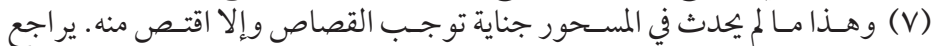

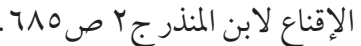

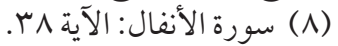


ففي هذا الحديث دلالة صريحة على أن المسلم لا يرث الكافر (v)،

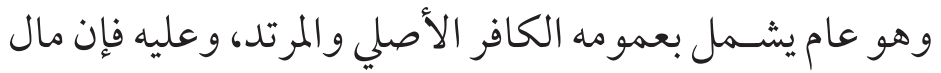

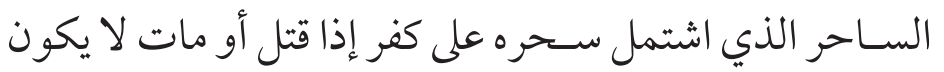
لو لوثثه وإنما لبيت مال المسلمين.

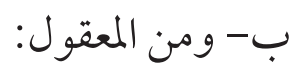

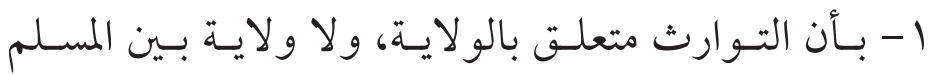

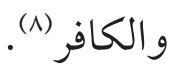
r - وبأنه قتل كافر ا فلا يرثه المسلم قياسا على عدم ميراثه للكافر

الأصلي (9) البقان

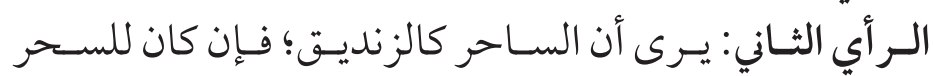

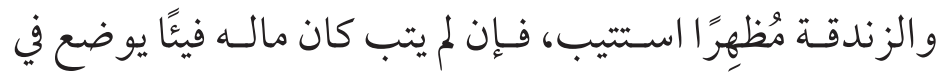

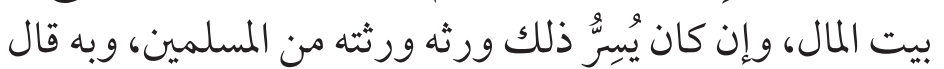
ابن عبد الحكم وأصبغ من المالكية (1.). دليل هذا الرأي: أ- دليله على أنه إن كان للسحر و الزيل إندقة مظهر ا فحاله لبيت المال:

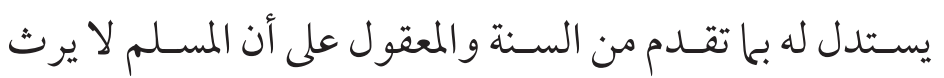
الكافر. ب- و وأما دليله على أن السـاحر إن كان مُسِرَّا للكفر فماله لورثثه

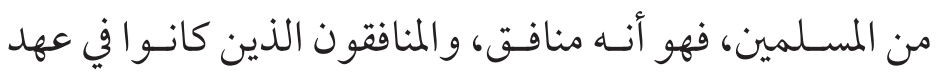

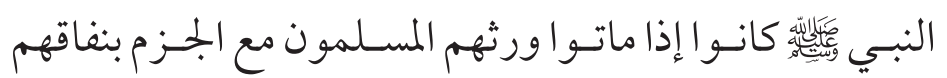

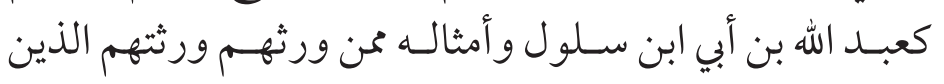
يعلمون بنفاقهم (11).

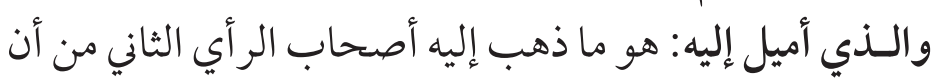

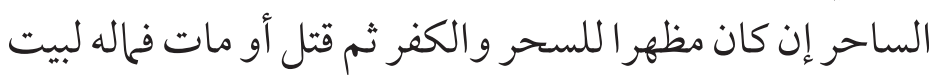

(V)

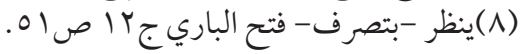

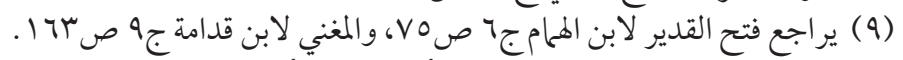

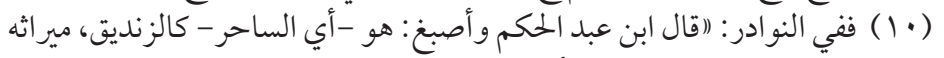

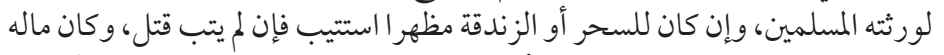

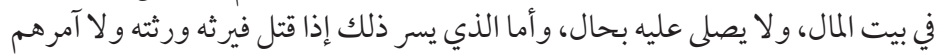

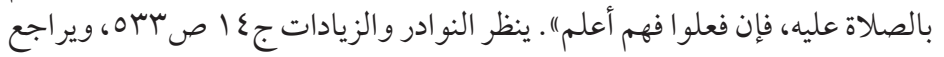

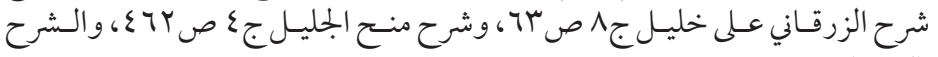

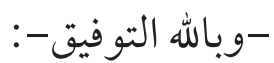
لذلـك حالتان: الحالة الأولى: إن قتل السـاحر المسـلم قصاصا،

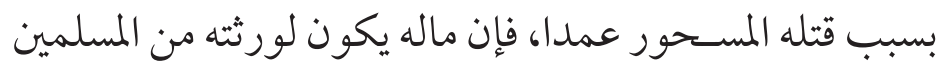

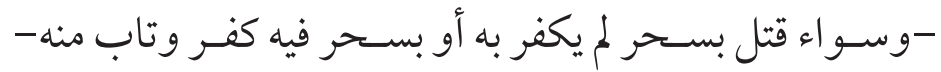

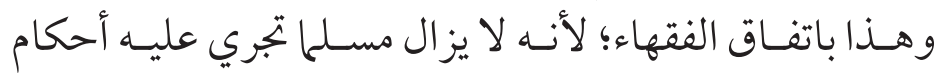

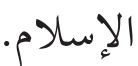

الحالة الثانية: إن قتل السـاحر بسبب كفره، فقد اختلف الفقهاء

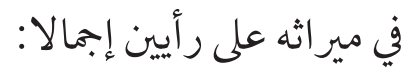

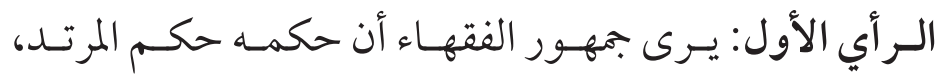

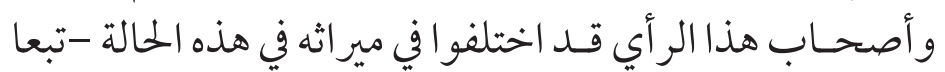

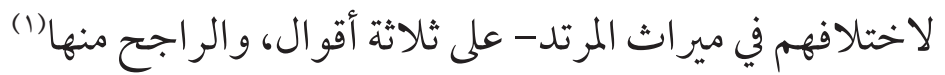

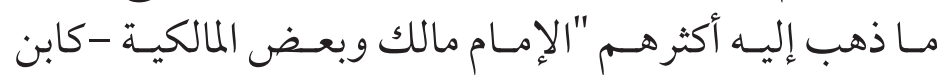

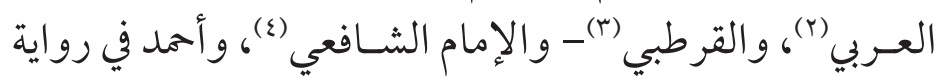

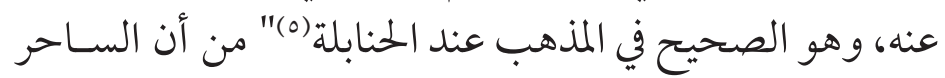

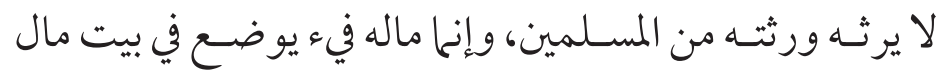

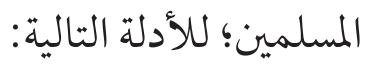

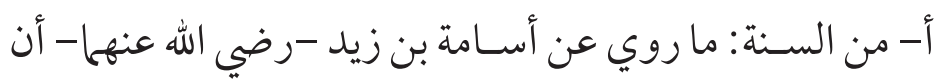

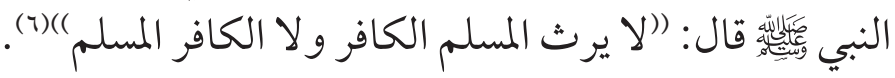
(1) القول الأول: أن ما اكتببه في حال إسلامه يكون لورثثنه من المسلمين، وما اكتسبه

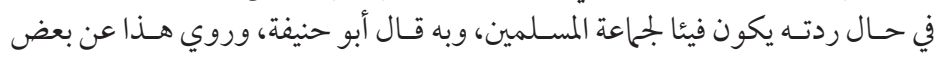
الصحابة رضي الله عنهم.

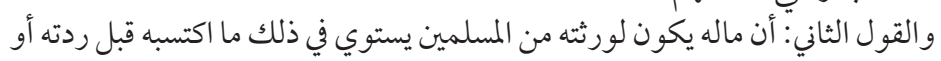

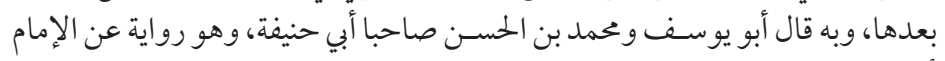

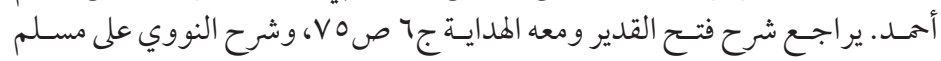

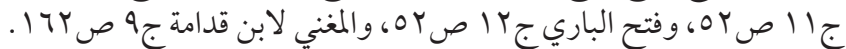

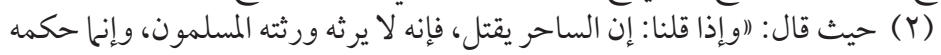

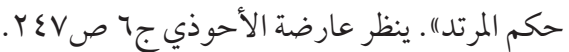

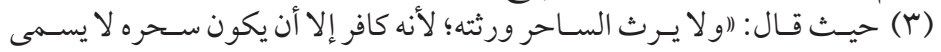

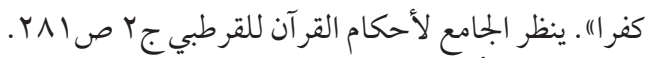

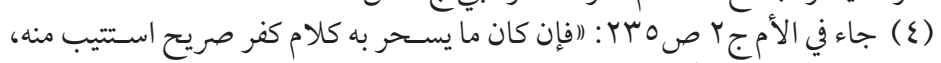

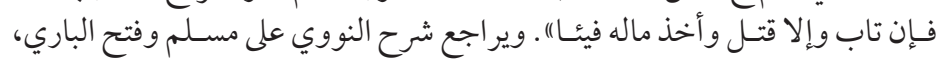

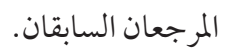
(0) وبه قال ابن عباس -رضي الأ عنها - وربيعة وابن أبي ليلى وغيرهم. يراجع المغني

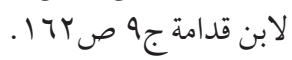

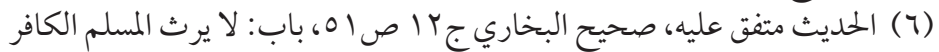

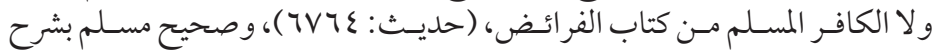
النووي جلا لص المه كتاب الفرائض. 
(ويعـزر) سـاحر بذلـك (بليغـا) لينكف هـو ومن يعمـل مثله

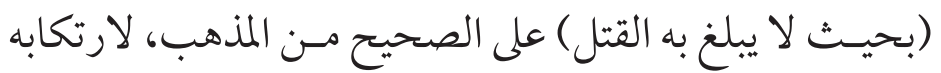

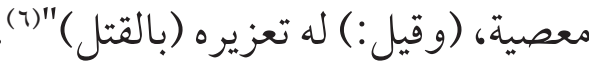
وفي المبسوط للطوسي: "فإن قال الساحر: أرقي ولكني لإني لا أوذي

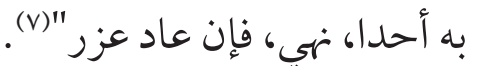

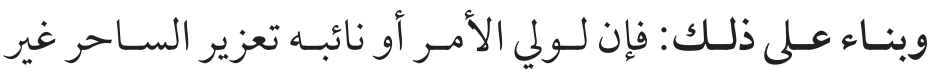

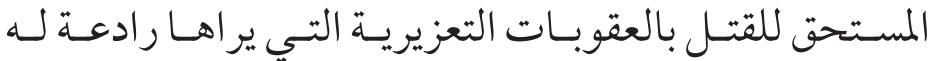

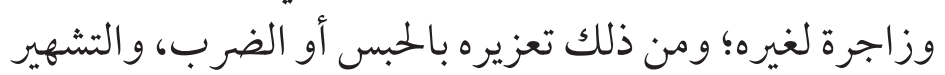
به في و سائل الإعلام المقرو عة و المسموعة وعة والمرئية.

\section{المبحث الثاني عقوبة الساحر النّمي}

اختلف الفقهاء في السـاحر الذمي ()، هل يعاقب بالقتل أم لا؟ على رأيين:

الر أي الأول: يرى أن الساحر الذمي لا يجيوز قتله بمجرد السحر،

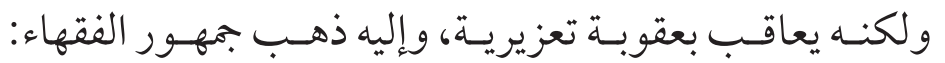

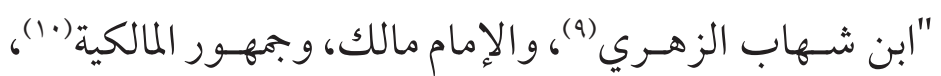

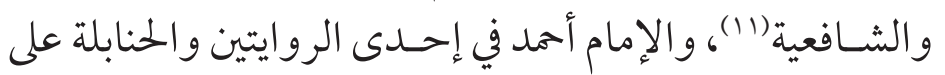

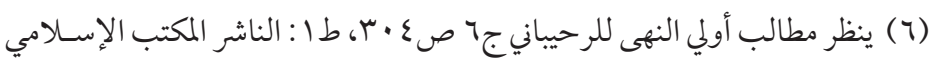

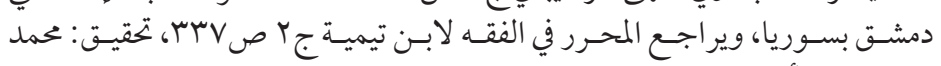

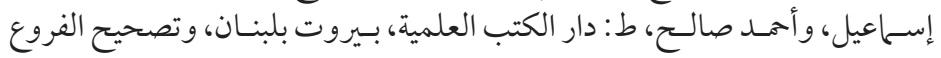

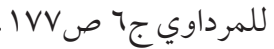

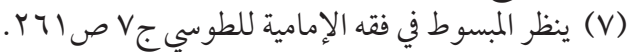

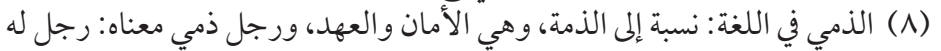

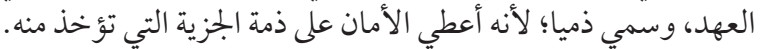

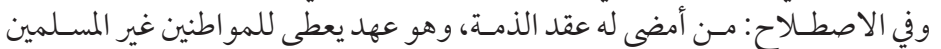

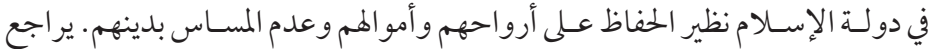

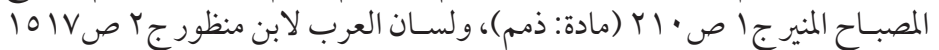

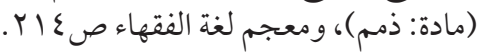

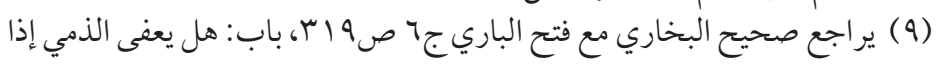
سحر؟ من كتاب الجزية والموادعة.

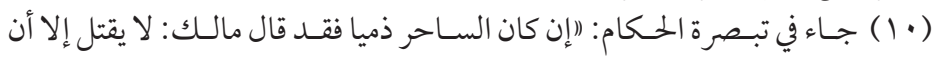

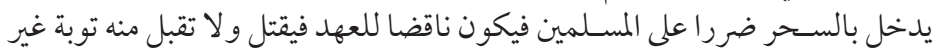

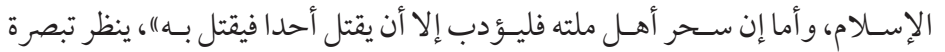

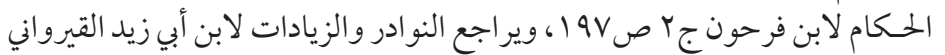

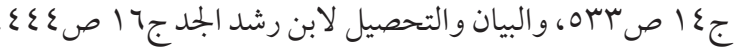

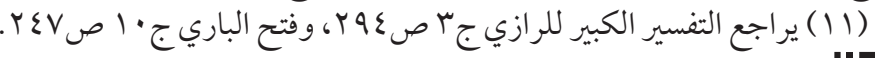

المال؛ لأنه مرتد، و إن كان مسر الكفره هائر باهماله لو المثته كالمنافق؛ لأننا

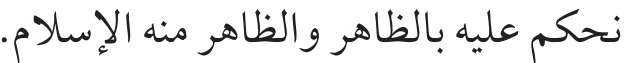

\section{المطلب الرابع}

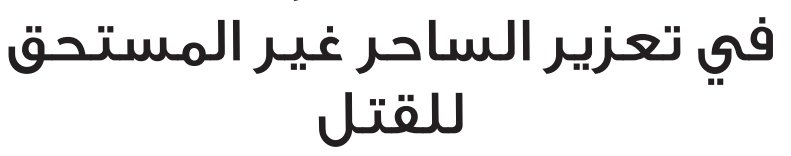

ذهـب القائلــون بعدم قتل الســاحر غير المســتحق للقتل -وهو

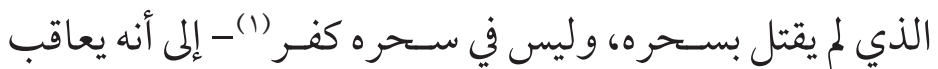

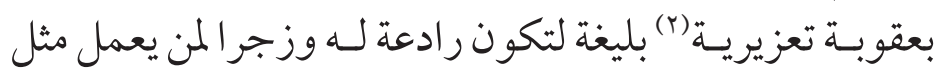
عمله، و إليك بعض ما صدر عنهم في ذلك: بكريك

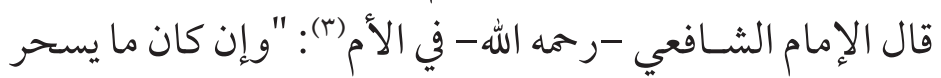

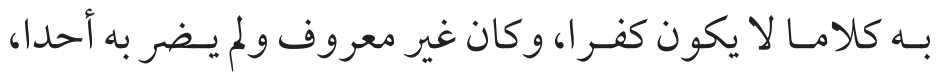

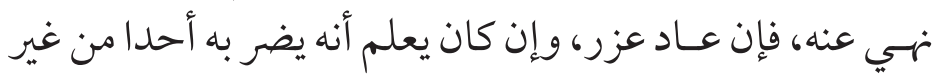

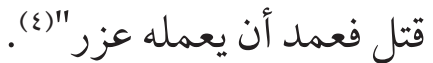

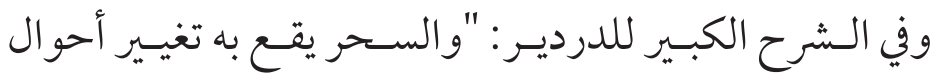

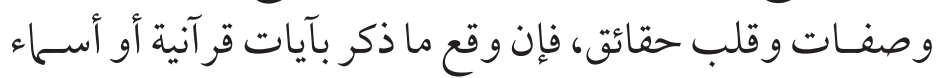
إلهية، فظاهر أن ذلك ليس بكفر، لكنه يحرم إن أدى إلى عداوة أو

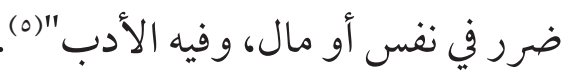
وفي مطالب أولي النهى: "(و لا) يقتل (من يسحر بأدوية وتدخين

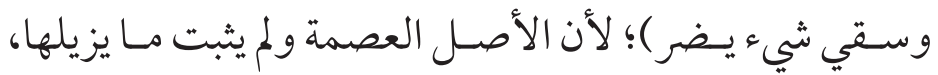
(1) (1) هؤلاء هم أصحاب الر أي الثاني كما تقدم في عقوبة الساحر المسلم.

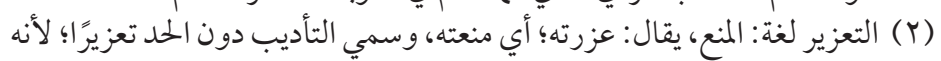

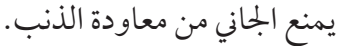

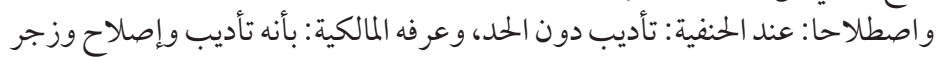

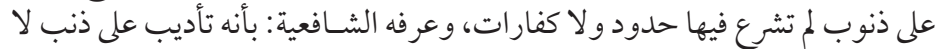

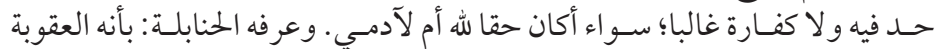
المشروعة على جناية لا حد فيها.

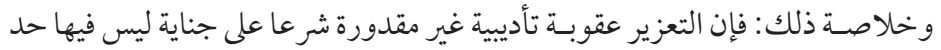

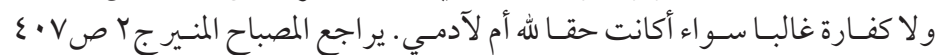

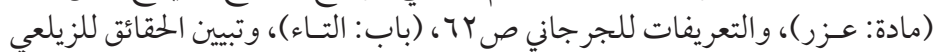

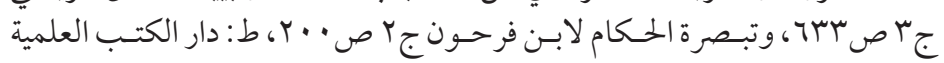

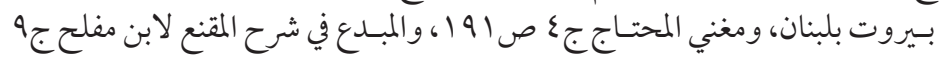

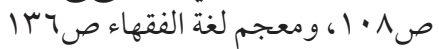

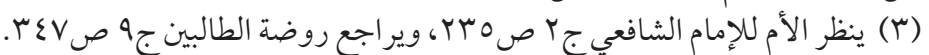

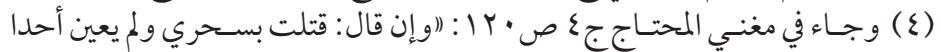

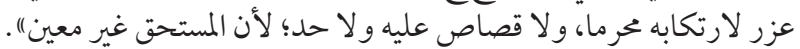

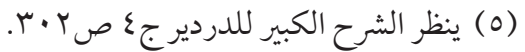


يفعل الشيء وما يفعله...." الحديث (v).

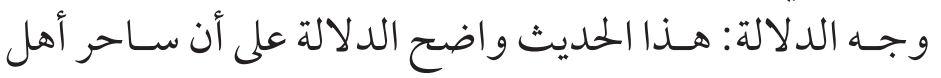

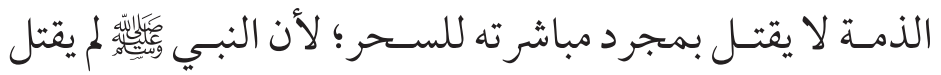

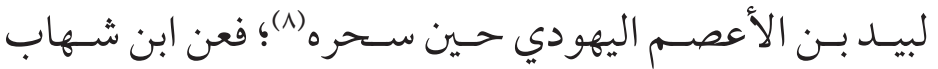

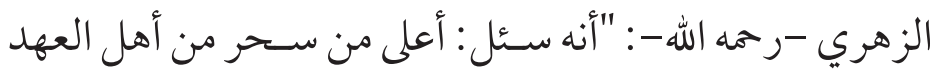

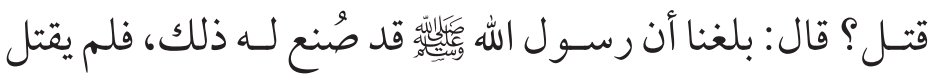

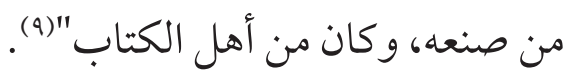
ونوقش ذلك بالآتي:

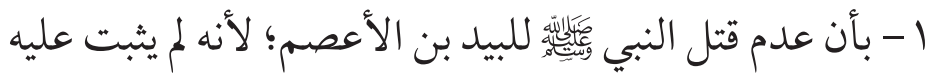
السحر لا بإقراره ولا بيينة (•).

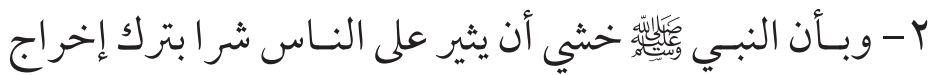

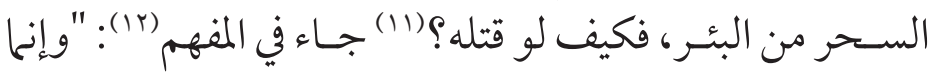

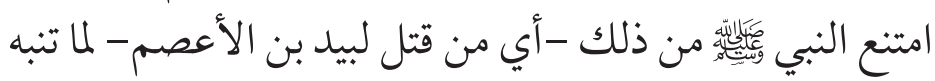

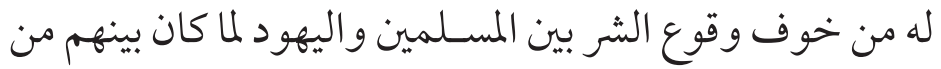

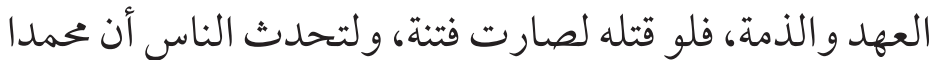
يقتل من عاهده فيكون ذلك منفر اعن الدخول في دينه و عهده".

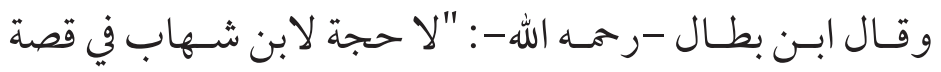

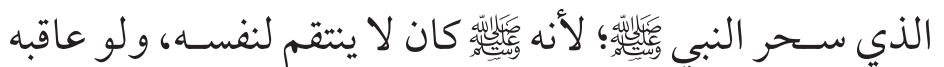

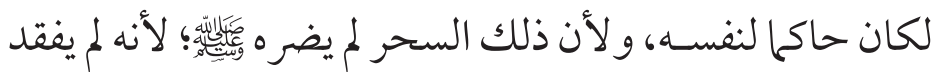

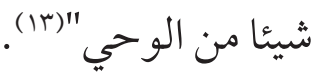

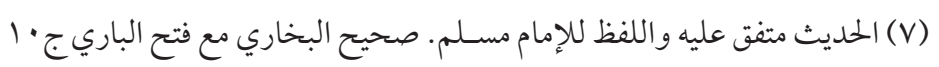

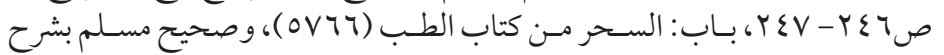

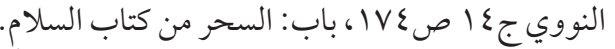

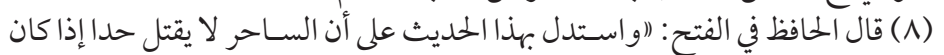

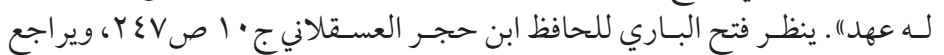

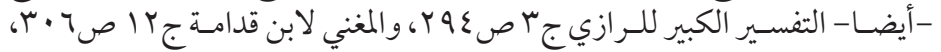

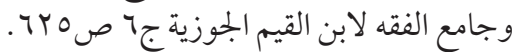

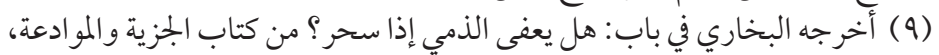

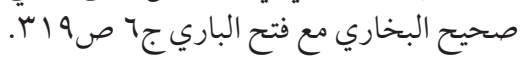

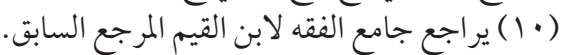

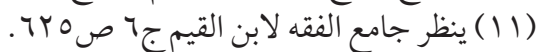

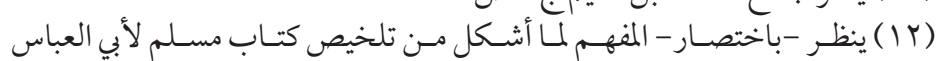

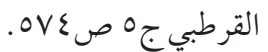

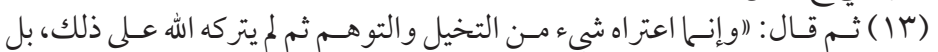

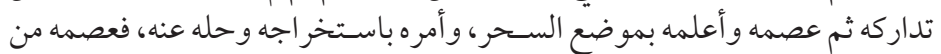

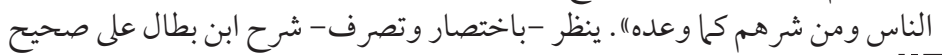

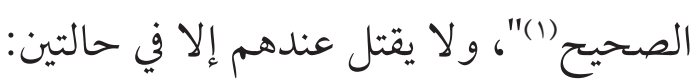

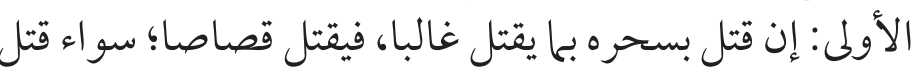

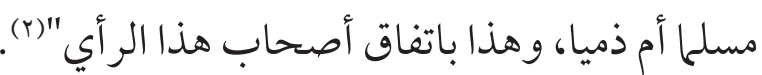

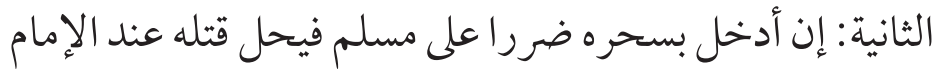

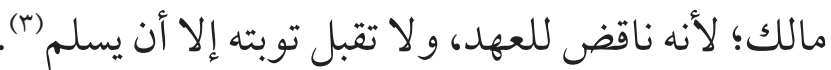

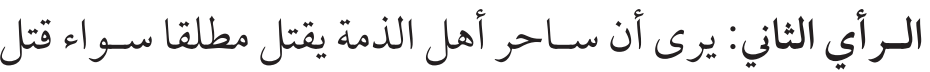

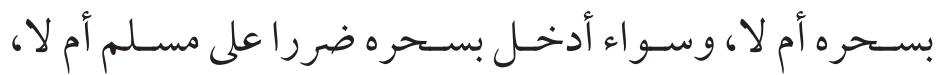

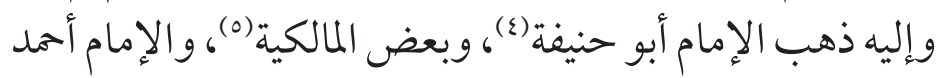
في الرواية الثانية(7)

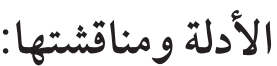

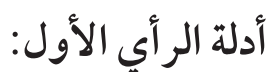

استدل جمهور الفقهاء على ما ذهبو ا إليه من السنة والمعقول: أ- فمن السنة:

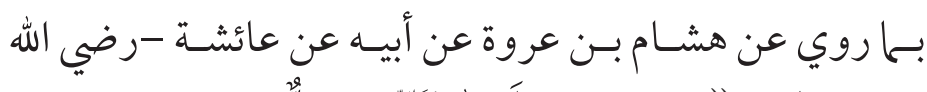

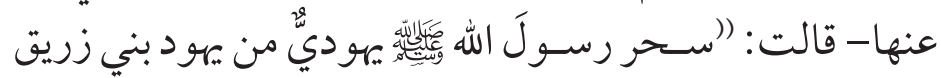

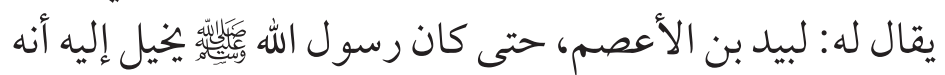

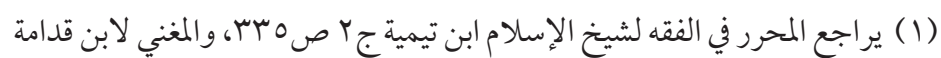

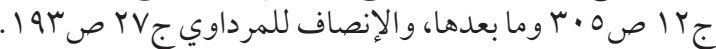

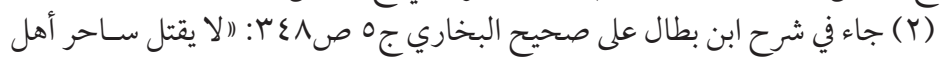

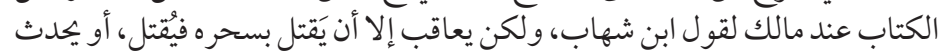

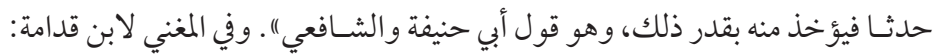

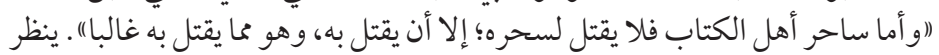

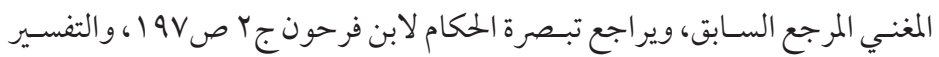

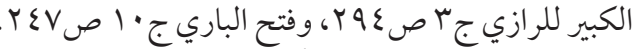

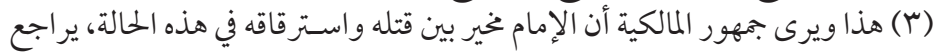

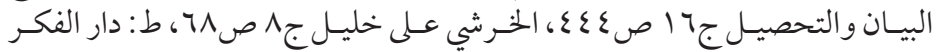

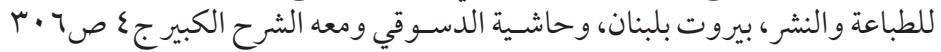
وما بعلمها.

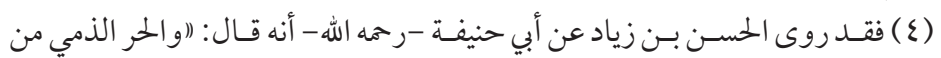

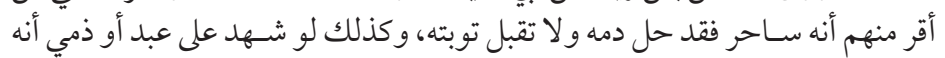

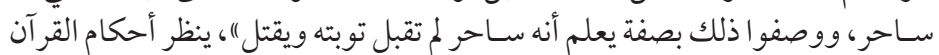

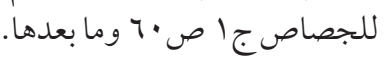

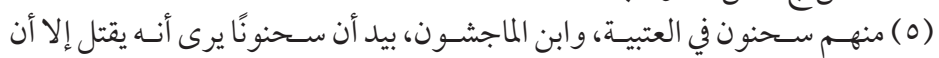

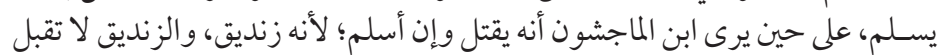

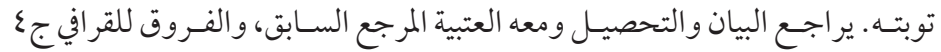

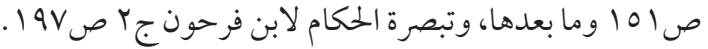

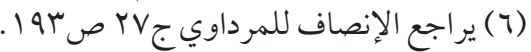


يتتض بالزنا من المحصن، فإنه لا يقتل به الذمي عندهم، ويقتل

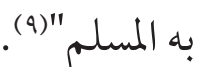

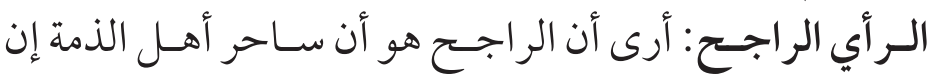

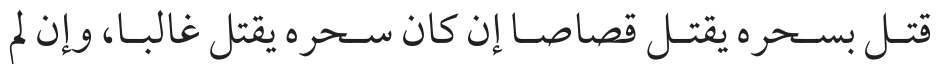

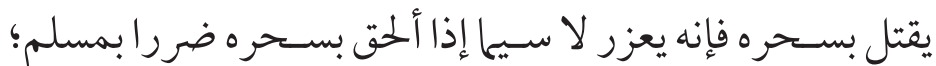

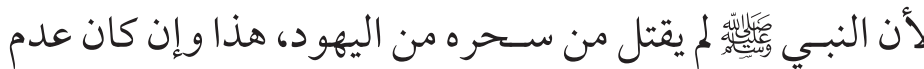

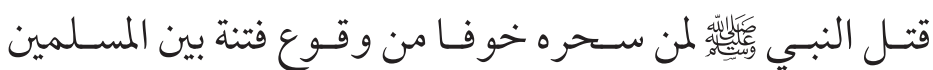

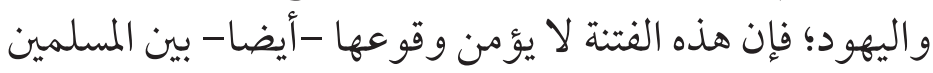

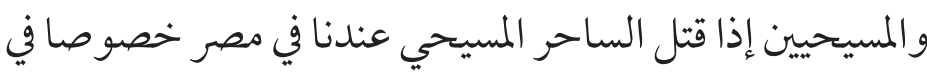
هذه الأيام.

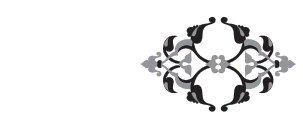

(9) ينظر المغني لابن قدامة وكشاف القناع المرجعان السابقان.
ب- ومن المعقول: بأن الشرك أعظم من سحر الذمي، ولا يقتل

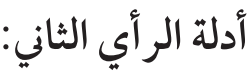
استدل القائلون بأن ساحر أهل الذمة يقتل مطلقا بالآتي:

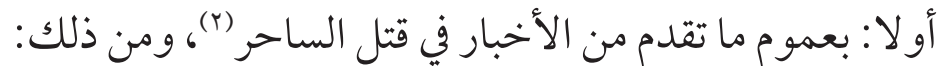
1 - مـا روي عن جندب بن عبد الله -رضي الله عنها - أنه قال:

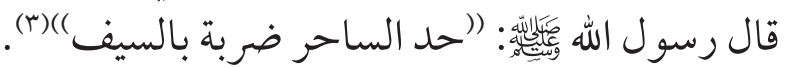

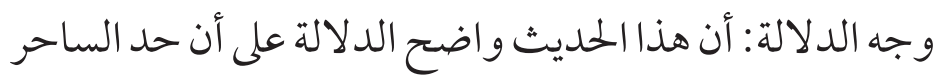

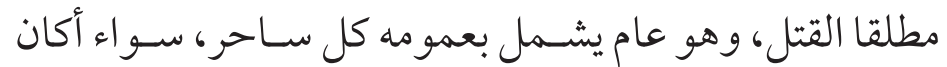

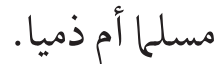

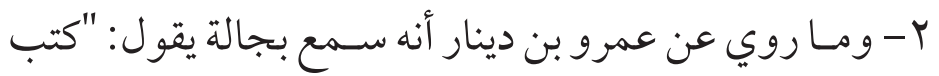

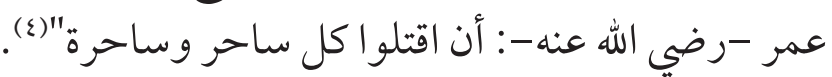

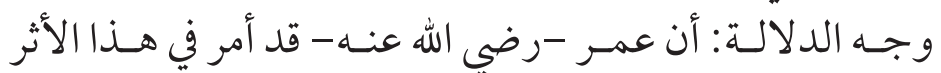

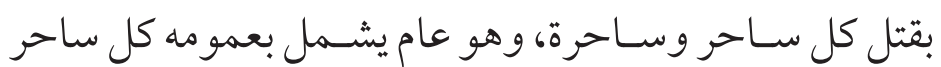

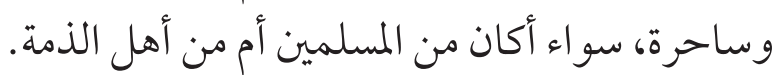

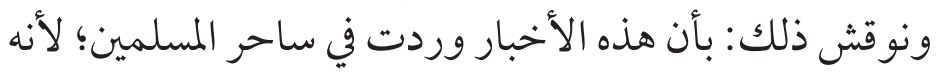

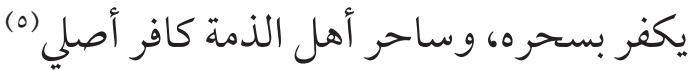

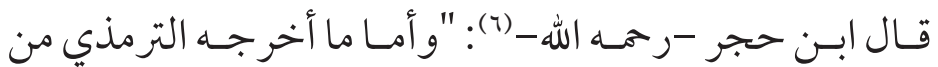

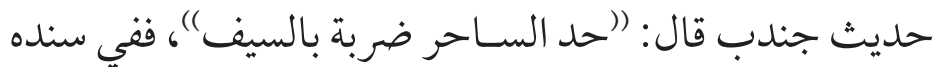
ضعف، فلو ثبت لخص من له عهد" (v).

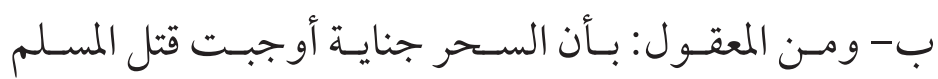
فأوجبت قتل الذمي كالقتل (ه).

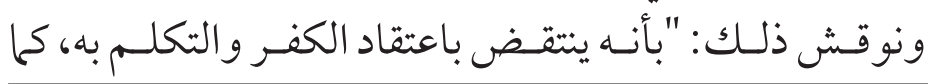

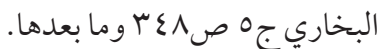

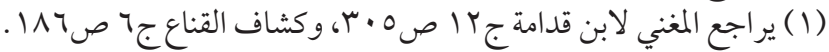

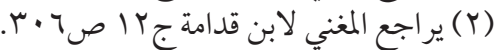

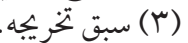

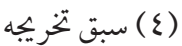

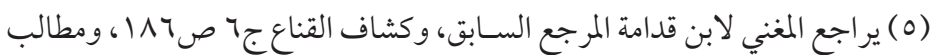

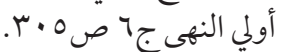

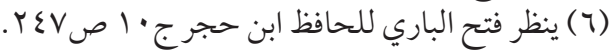

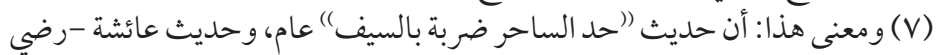

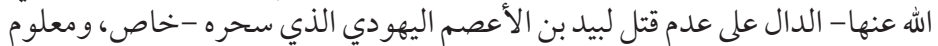

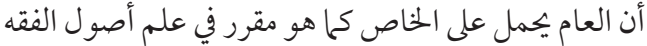

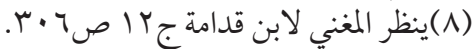


بعد هذا التمهيد أقول -وبالله التوفيت -:

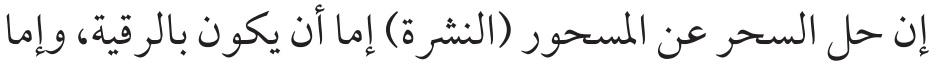
أن يكون بالسحر، وقد تناولت ذلك في مبحثين:

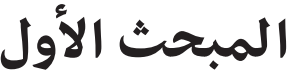

\section{حل السحر عن المسحور بالرقية وبعض النشرة

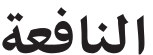

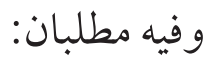

\section{المطلب الأول حكم حل السحر عن المسحور بالرقية المسلة}

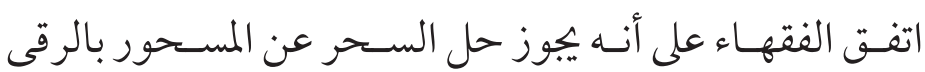

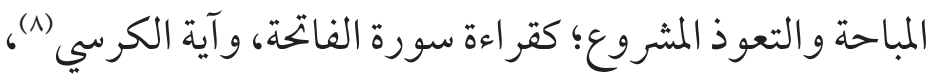

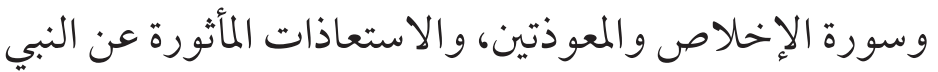

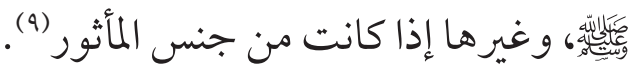

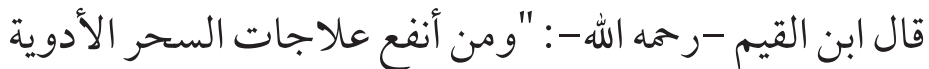

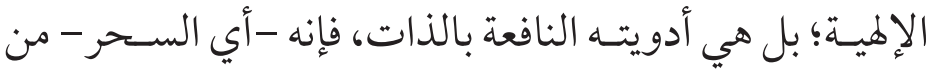

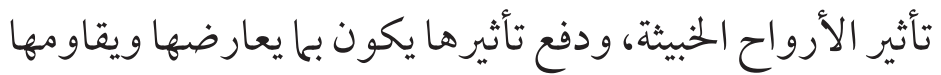

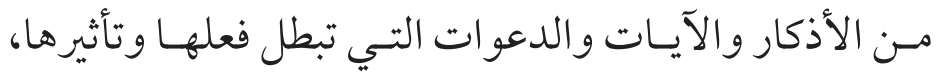

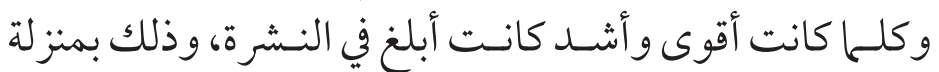

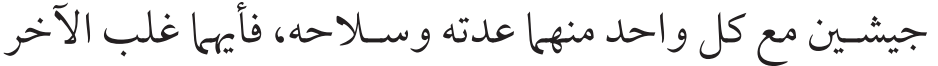

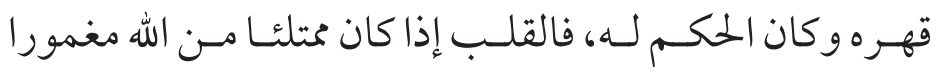

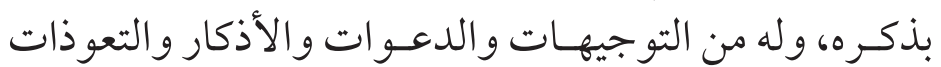

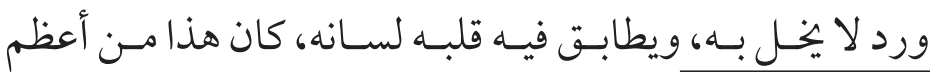

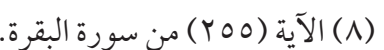

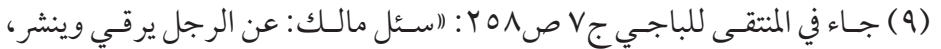

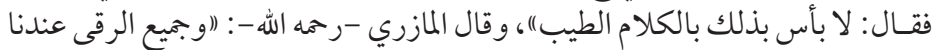

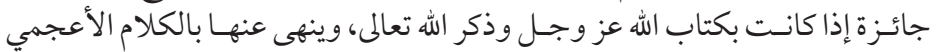

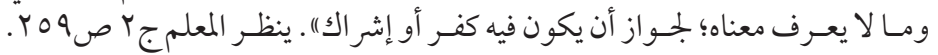

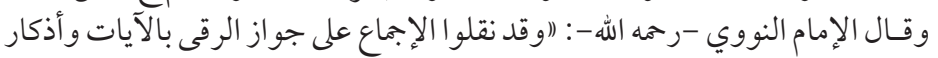

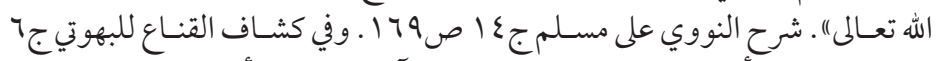

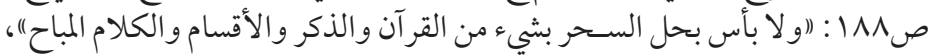

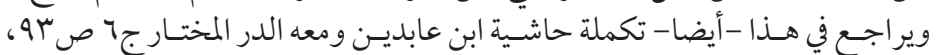

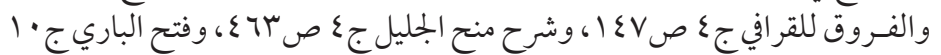

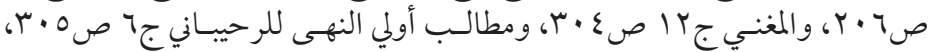

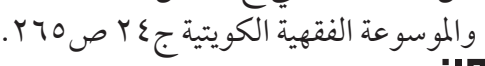

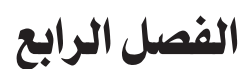

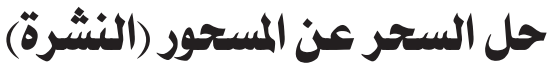

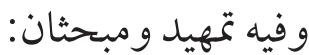

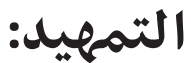

\section{في تعريف النشرة ودليل مشروعيتتها}

$$
\text { أ- تعريف الثرة: - أن }
$$

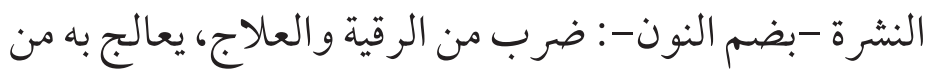

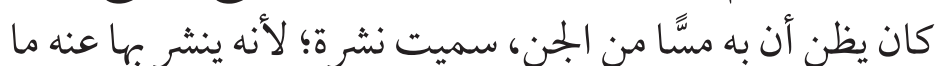

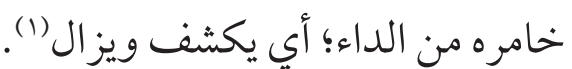

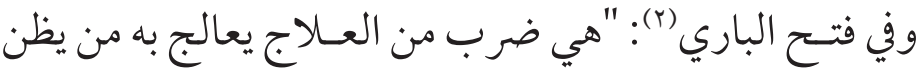

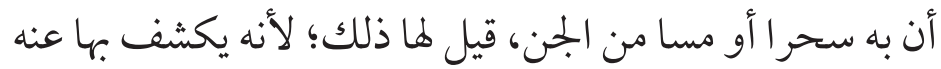

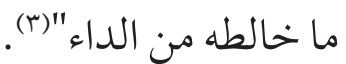

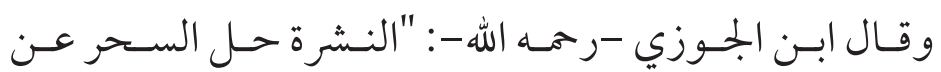

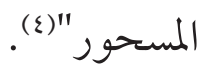

ب- دليل مشروعيتها: دل على مشروعية النشرة أحاديث منها:

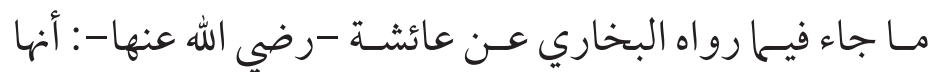

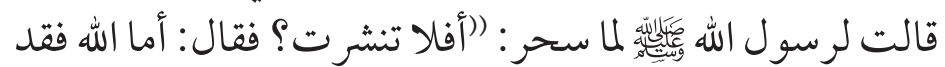
شفاني، وأكره أن أثثر على أحد من الناس شر ()(o).

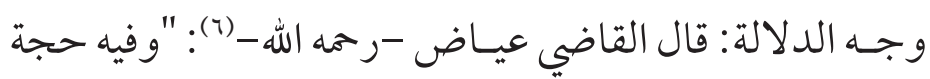

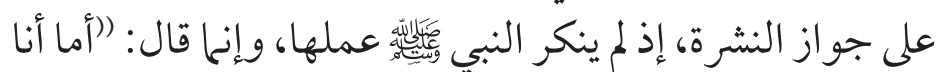

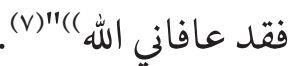

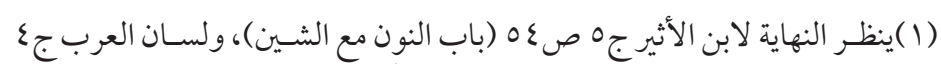

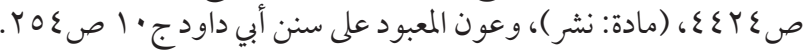

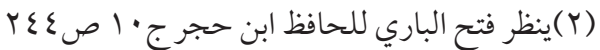

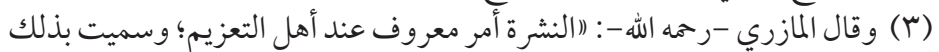

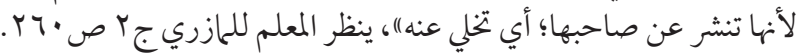
(ع ) ينظر -نقلا عن ابن الجوزي - فتح الباري، المرجع السابق.

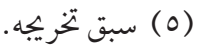

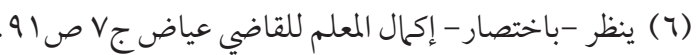

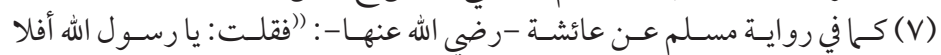

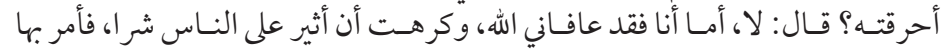

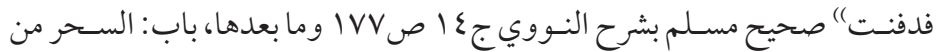

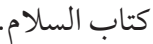


وجه الدلالة: في هذا الحديث دلالة على استحباب الرقية بالقر آن

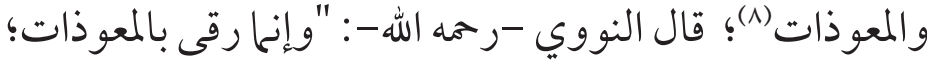
لأنهن جامعات للاستعاذة مـن كل المكروهات جملة وتفصيلا،

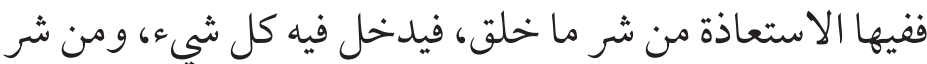

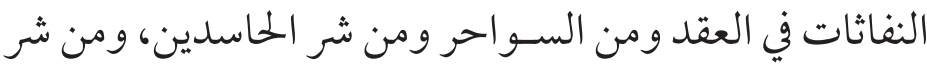
الوسواس الخناس، والله أعلم" (9). بـ- ومــا روي عن جابر بن عبـــ الله -رضي الله عنهم) - أنه قال:

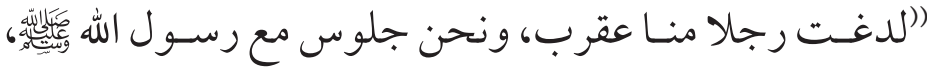

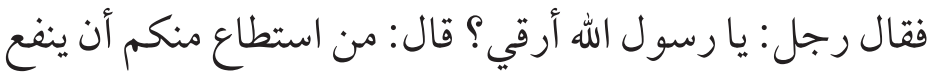

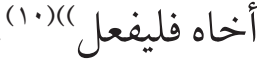
وجه الدلالة: هذا الحلديث فيه دلالة على رقية المريض ومعالجته

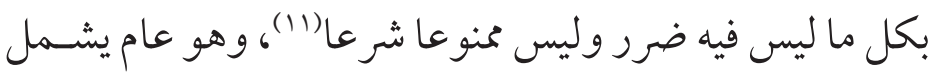

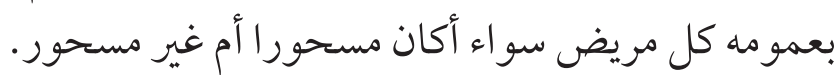

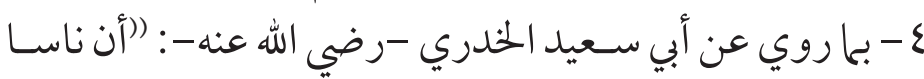

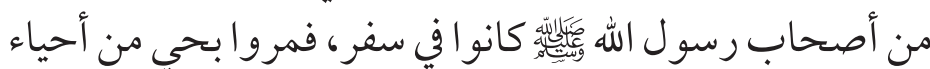

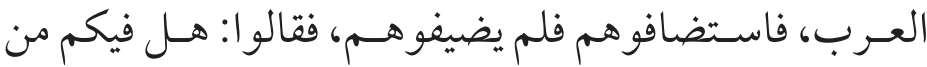

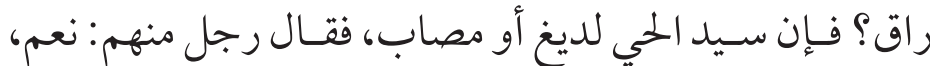

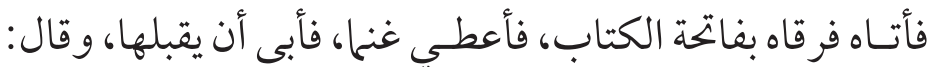

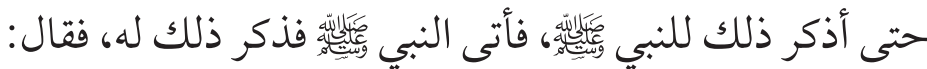

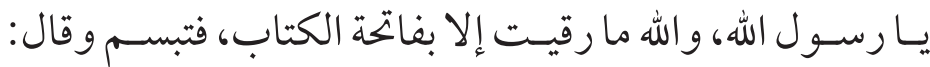

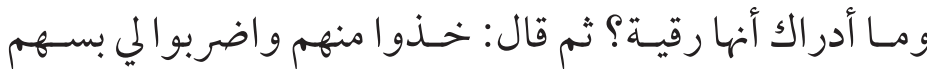
معكى (Ir)( ()

(1) (هنظر -بتصرف - شرح النووي على مسلم. (9) ينظر شرح النووي على مسلم، المرجع السابق.

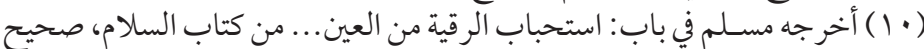

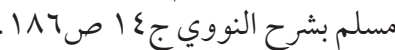

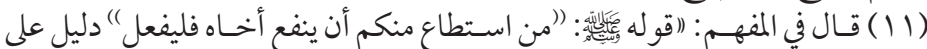

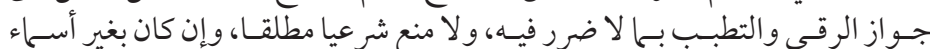

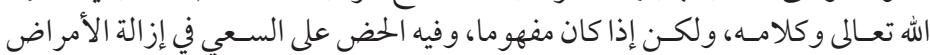

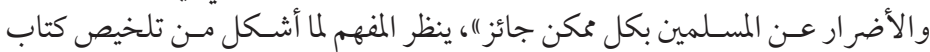

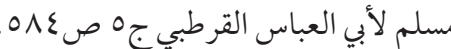

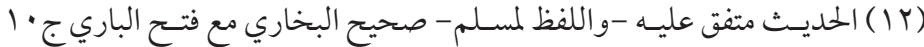

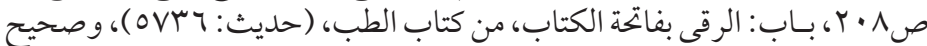

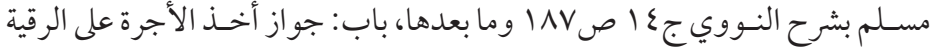
بالقر آن و الأذكار من كتاب السلام.
الأسـباب التي تمنع إصابة السـحر له، ومن أعظم العلاجات له له

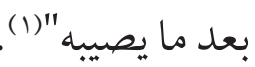
وقال الحافظ ابن كثير -رمه الله-: "أنفع ما يستعمل لإذهاب

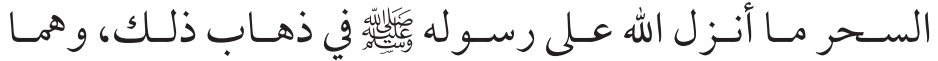

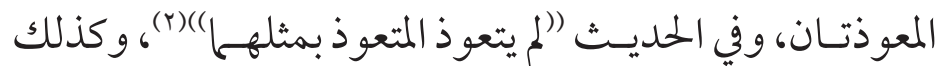
قراءة آية الكرسي، فإنها مطردة للشياطين" (').

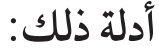
لقــد دل عـلى جـواز حل السـحر عن المسـحور بالرقيـة المباحة والأذكار المشروعة أحاديث منها:

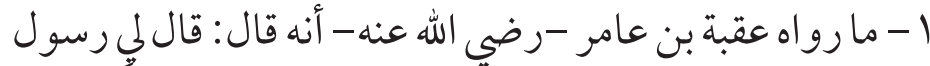

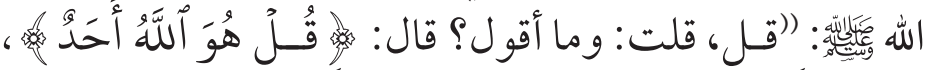

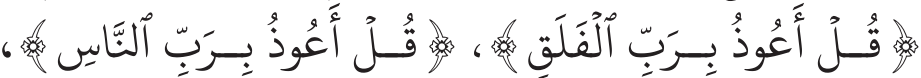

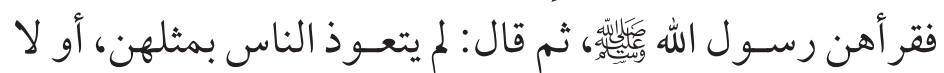
يتعوذ الناس بمثلهن) (و).

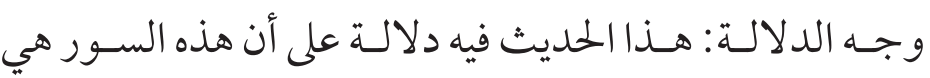

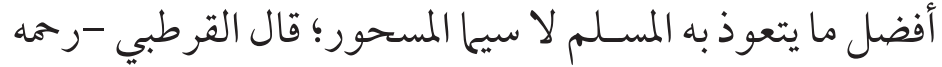

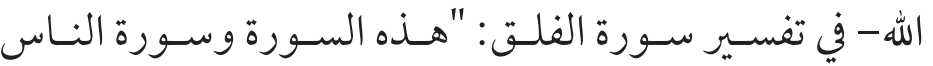

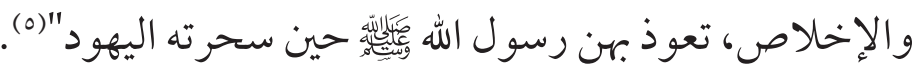

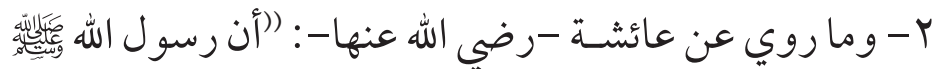

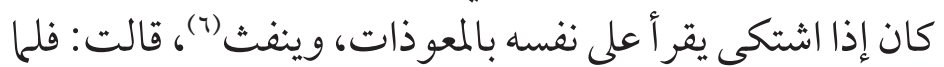

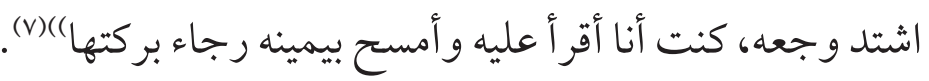

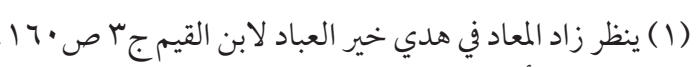

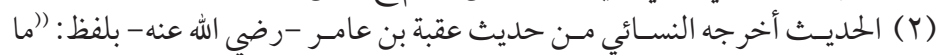

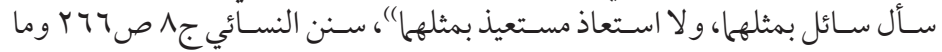

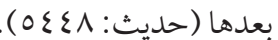

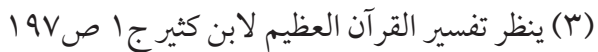

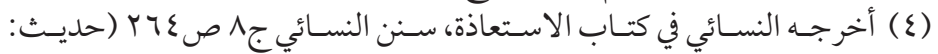

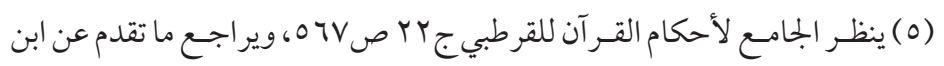

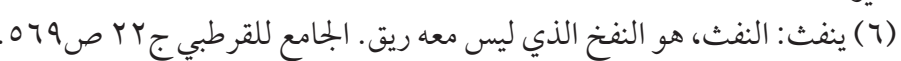

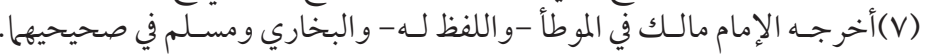

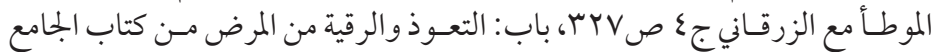

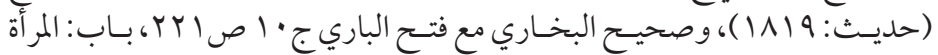

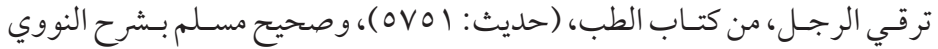

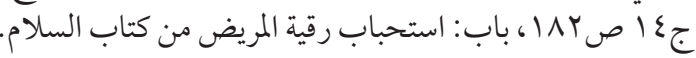




\section{المبحث الثاني \\ حل السحر عن المسحور بسحر مثله}

من المعلوم أن السحر مرض من الأمر اض وعلة من العلل، فإذا

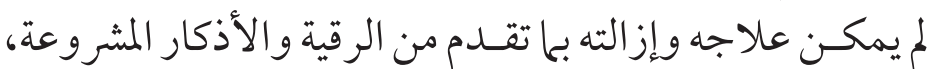

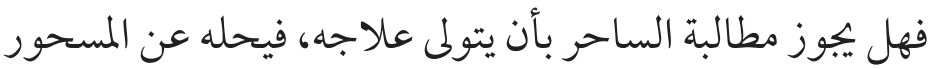

وبعبارة أخرى: هل يجوز حل السـحر عن المسـحور بسحر مثله

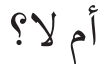

اختلف الفقهاء في ذلك على رأيين: الر أي الأول: يرى أنه يجوز حل السحر عن رأين: المستحور بسحر مثله،

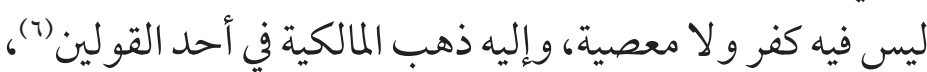

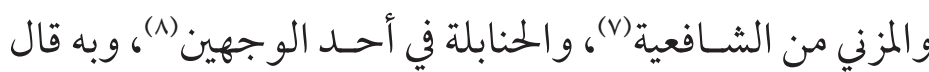

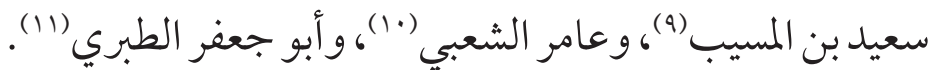

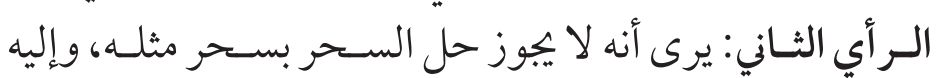

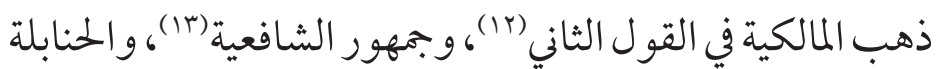

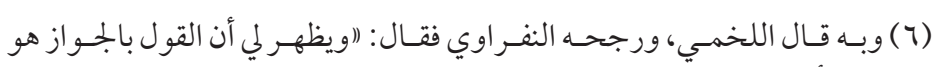

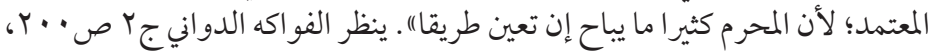

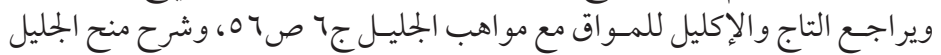

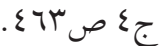
(V)

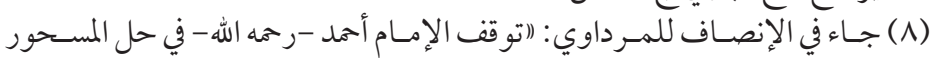

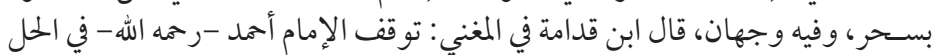

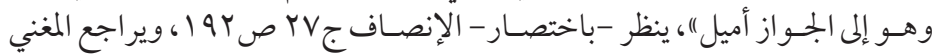

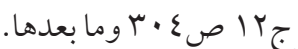

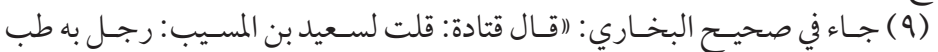

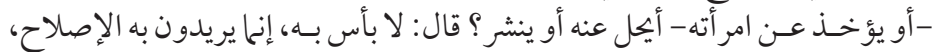

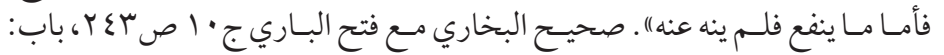

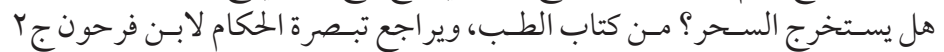

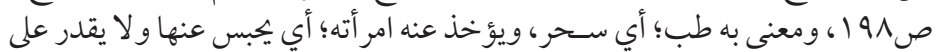

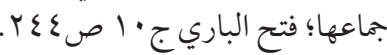

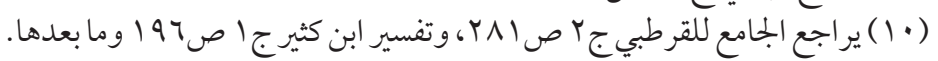

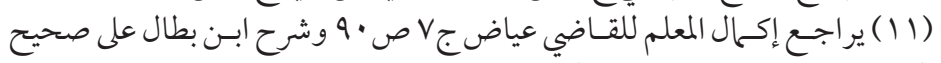

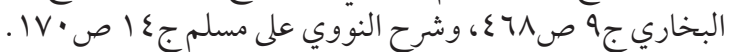

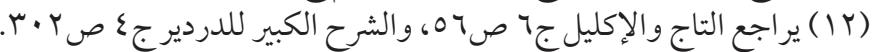

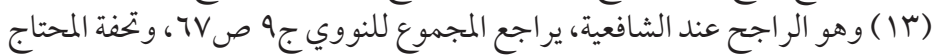

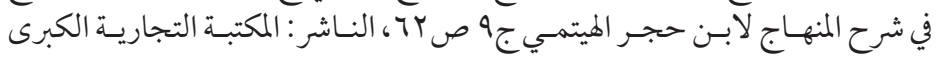

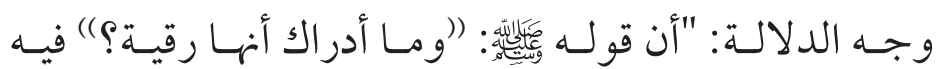

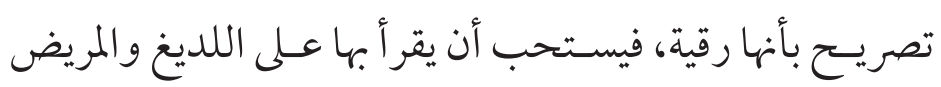

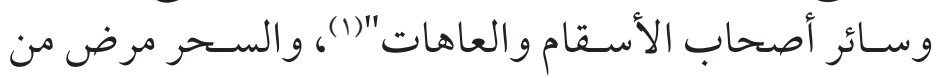
الأمر اض، فيستحب رقية المسحور بالفاتحة.

\section{المطلب الثانبي:}

\section{بعض النشرة النافعة في علاج السحر}

هناك بعض النشرة النافعة والمفيدة بإذن الله تعالى في حل السحر

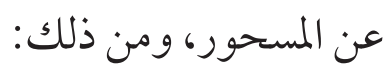
1 - استـخر اج السـحر وإبطاله إذا علـم مكانه بالطـرق المباحة

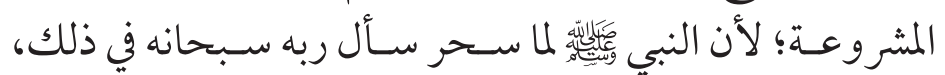

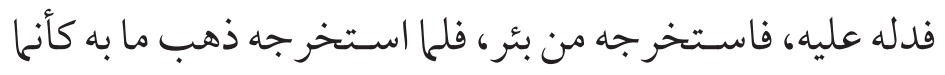

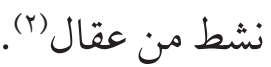

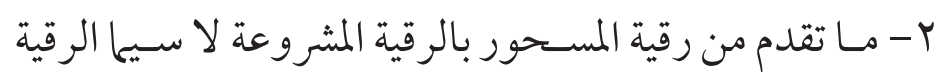

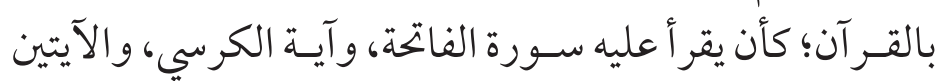

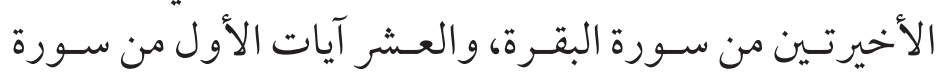
الصافات، وسورة الإخلاص، والمعوذتين.

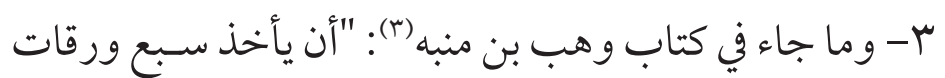

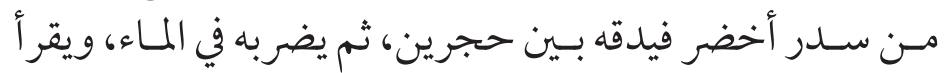

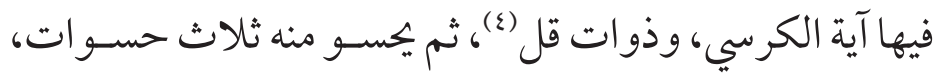

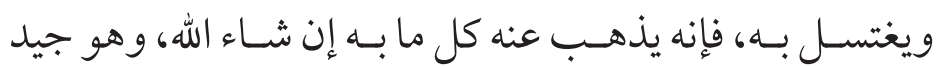
للرجل إذا حبس عن أهله" (0. ن.

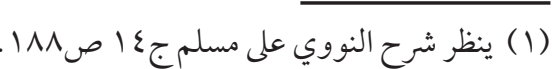

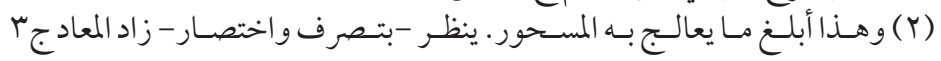

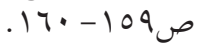

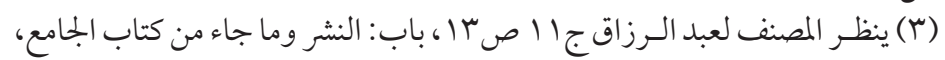

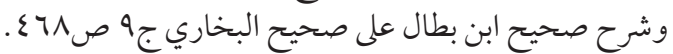

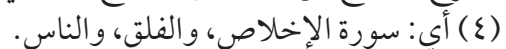

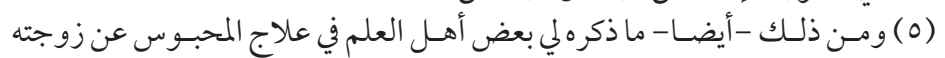

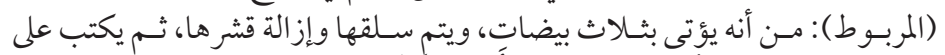

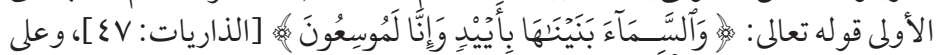

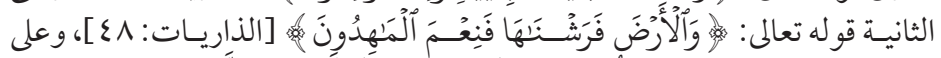

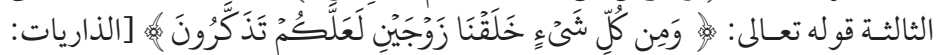

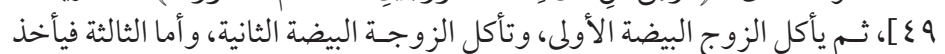

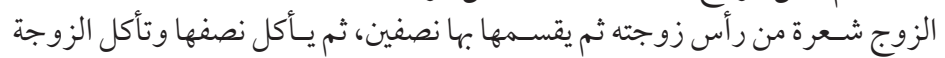
النصف الباقي، وقد جرب هذا فكان فيه النفع بإذن الله تعلى. 
بعمومه كل من عنده علم بذلك وعلاجه سـو اء أكان ساحر أم أم

غير ساحر (1).

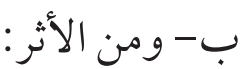

بها تقدم عن قتادة أنه قال: قلت لسـعيد بن المسيب -رمحه الله-:

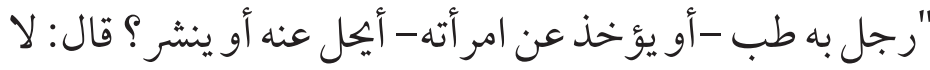

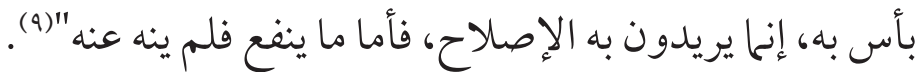
جـ-ومن المعقول: بأن حل السحر بسحر مثله وإن كان مخظور ا، إلا أنه أبيح لأجل

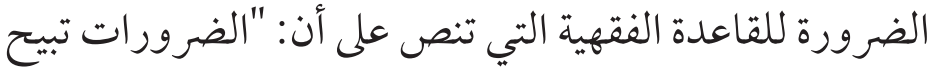

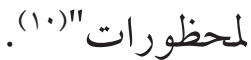

أدلة الر أي الثاني ومناقشتها: استدل أصحاب الر أي الثاني على ما ذهبو ا إليه من السنة والأثن: أ- فمن السنة: - أسنا: بـا رواه أبـو داود عن جابر بـن عبــ الله -رضي الله عنهـا- أنه

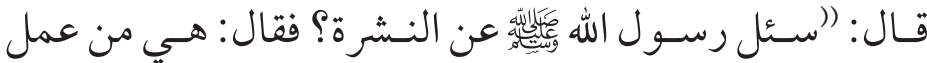
الشيطان)(1)(11).

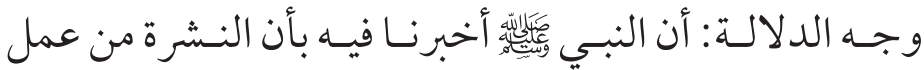
الشيطان، وفي هذا دلالة و اضحة على حر متها. ونوقش ذلك بالآتي: 1 - بأن الحديث محمول على ما إذا كانت النشرة بأشـياء خارجة

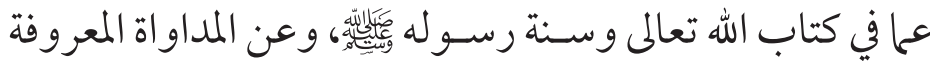

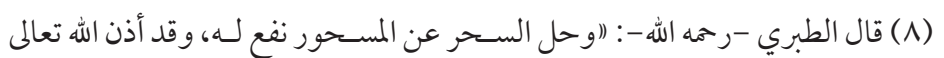

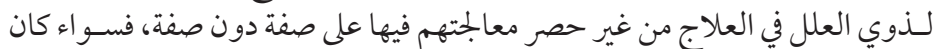

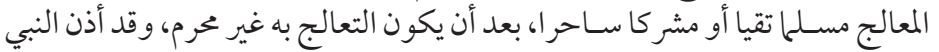

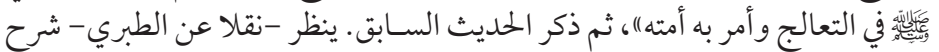

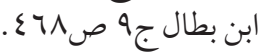

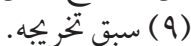

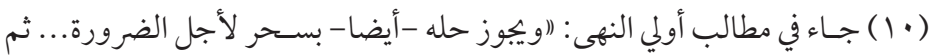

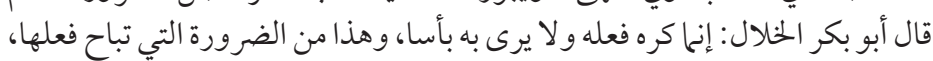

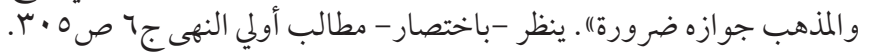

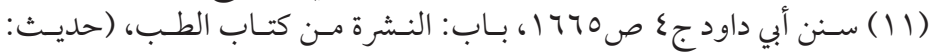

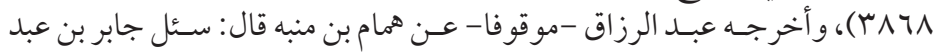

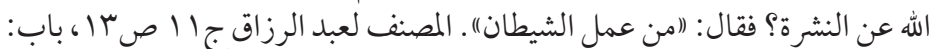

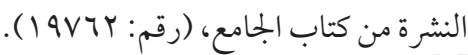

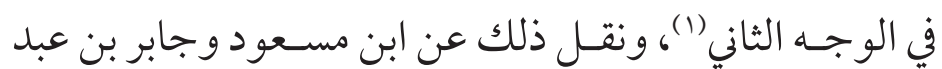
الله -رضي الله عنهم -، وبه قال الحسن البصري رحمه الله (r). الأدلة ومناقشتها:

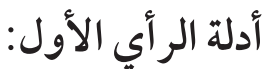

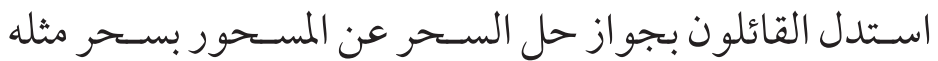
بالسنة و الأثر والمعقول:

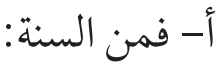
1 - بـا تقدم في حديث جابـر بن عبد الله -رضي الله عنها|- : أن

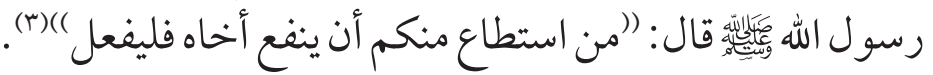

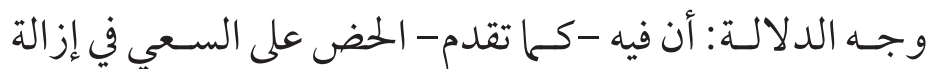

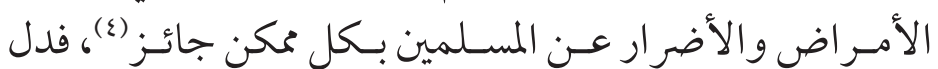

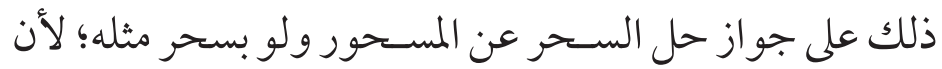

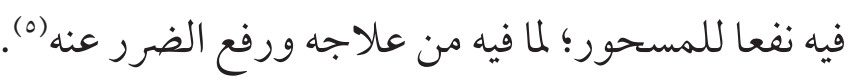

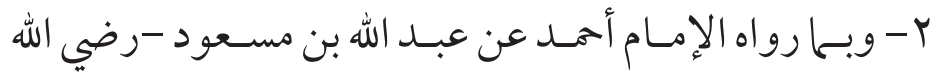

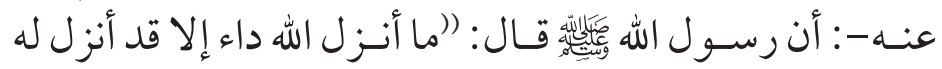

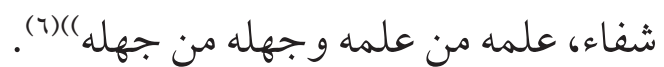

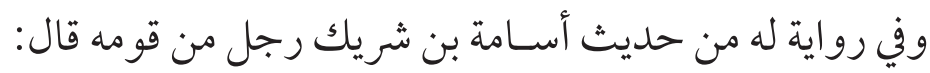

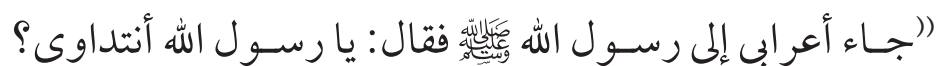

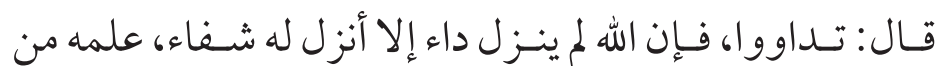

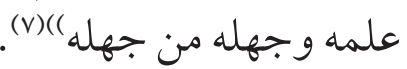

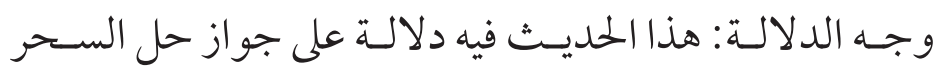

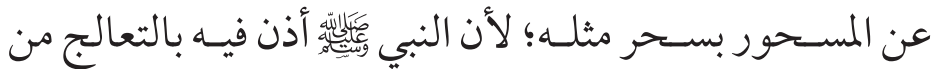

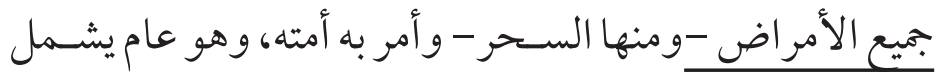

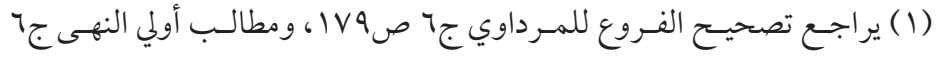

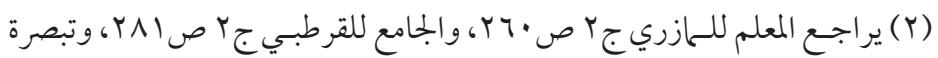

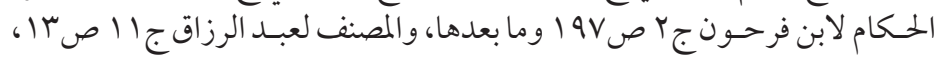

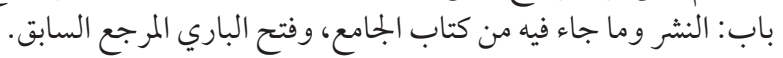

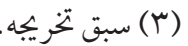

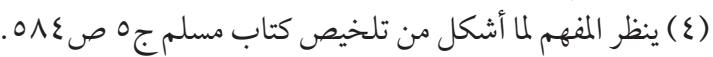

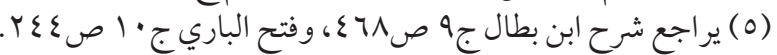

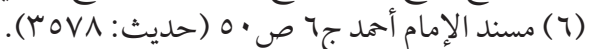

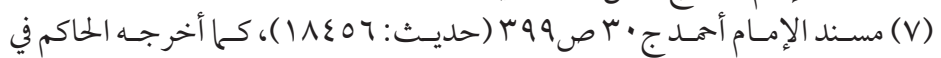

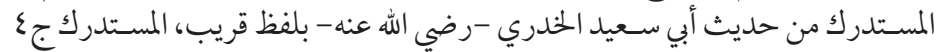

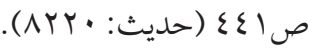


r - وبــأن حصر النشرة في السـحر ليس عـلى ظاهـره، لأنه قد

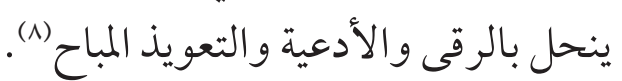

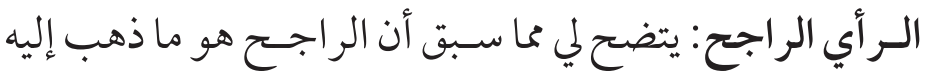

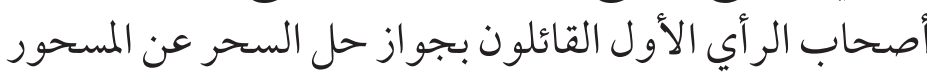

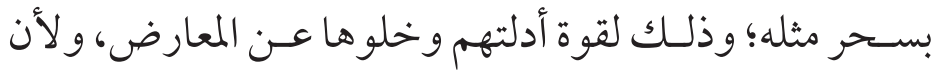

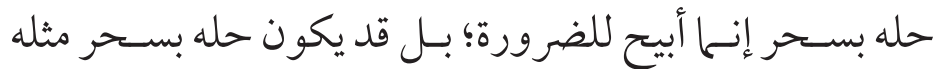

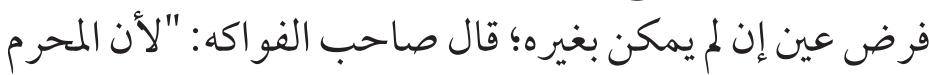

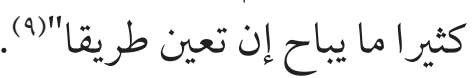

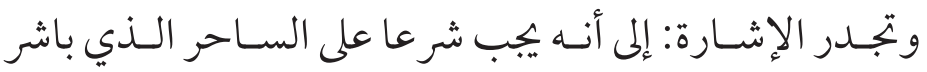

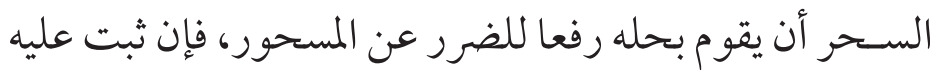

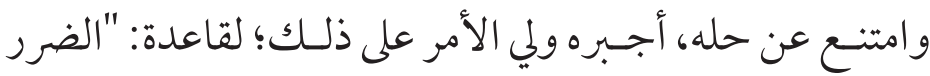

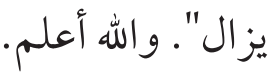

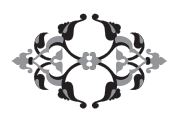

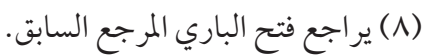

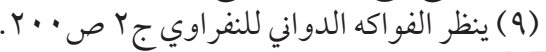

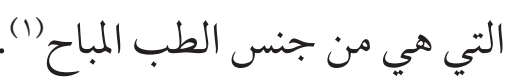

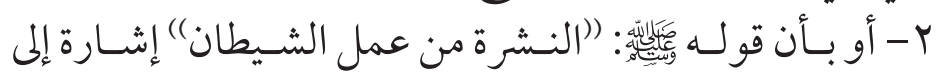
أصلها، ويختلف الحكم بالقصد، فمـن قصد بها خيرا كان خيرا

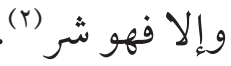

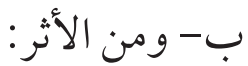
1 - بــا روي عـن عبد الله بن مسعود - -رضي الله عنه - أنه قال:

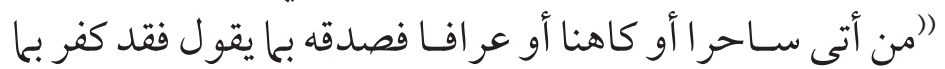

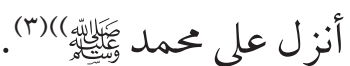

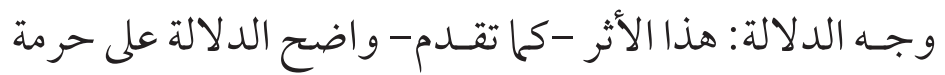

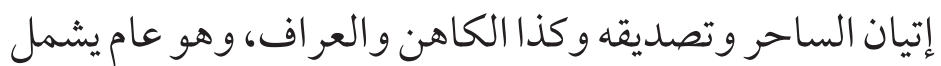

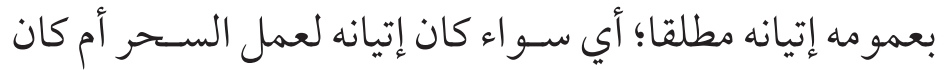
لحله عن المسحور "النشرة" (s). ونوقش ذلك: بأن المحرم هو إتيان الساحر لعمل السحر؛ لما فيه

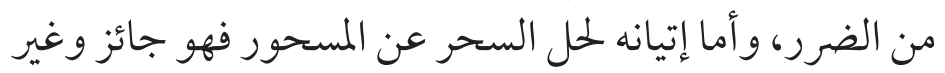

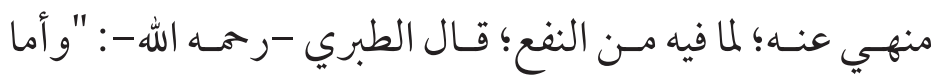

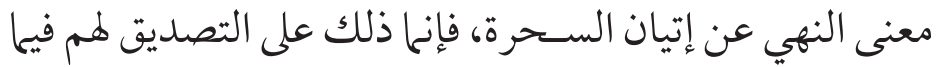

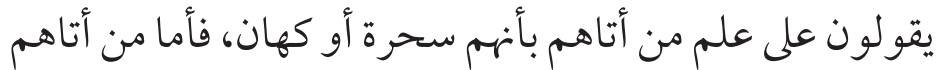

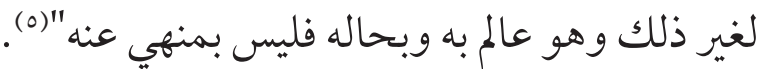

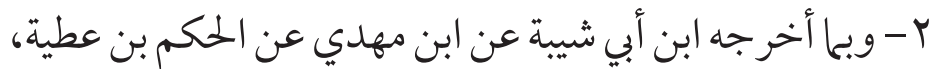

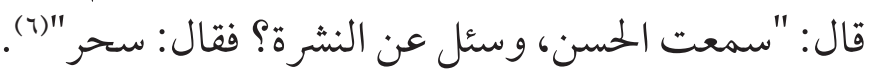

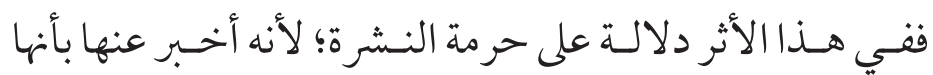
سحر ومعلوم أن السحر حرام كما سبق.

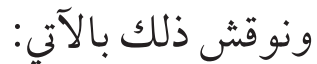

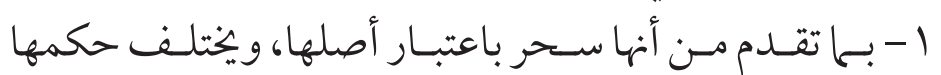

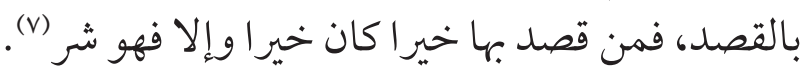

$$
\begin{aligned}
& \text { (1) ينظر -بتصرف- المعلم للمازري جr ص. • r r، والمفهمجه ص. } 04 .
\end{aligned}
$$

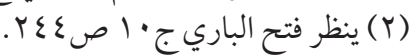

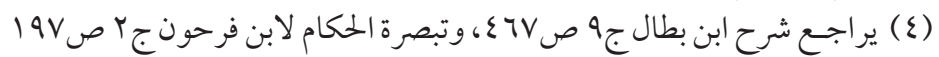

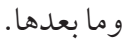

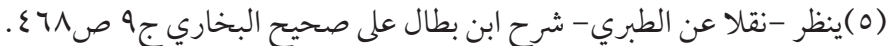

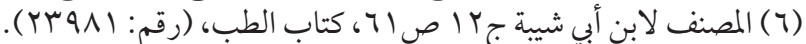

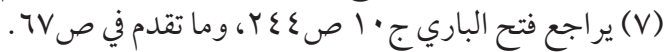


هذا وقد استشنى الشـافعية من ذلك إعطاء الأجـرة على تعليم

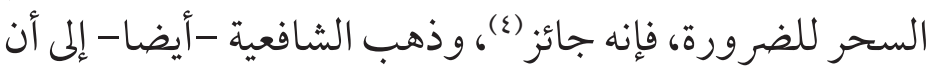

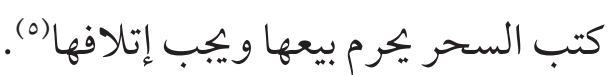

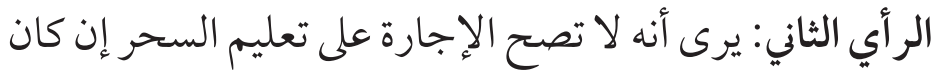

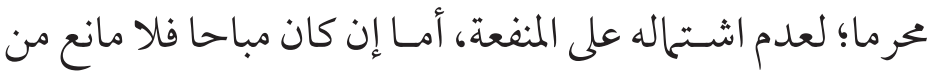

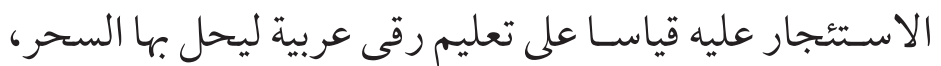
وإليه ذهب الحنابلة (7).

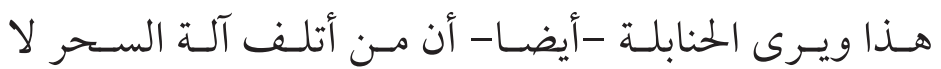

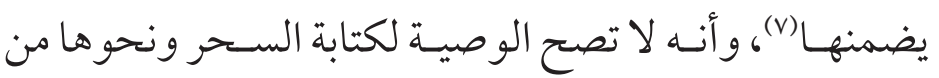

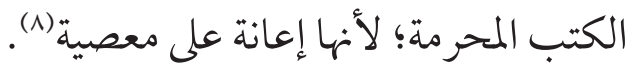

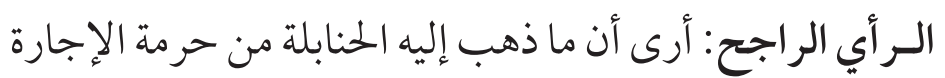

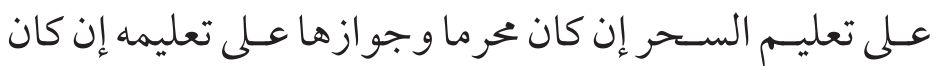

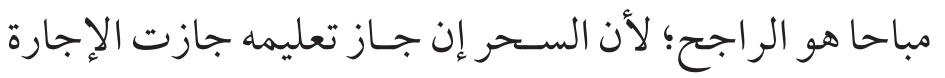
عليه وإلا فلا.

\section{المبحث الثاني \\ الإجارة على حل السحر}

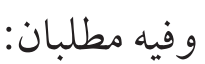

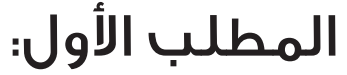 \\ حكمم الإجارة على حل السحر بالرقيـة الصفية المياحة}

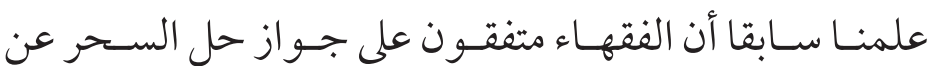
المسحور وإبطاله بالرقى المباحة والأذكار المشروعة.

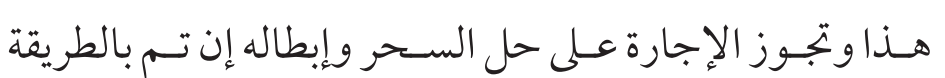

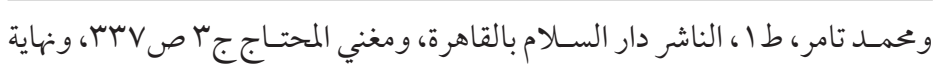

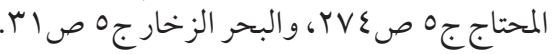

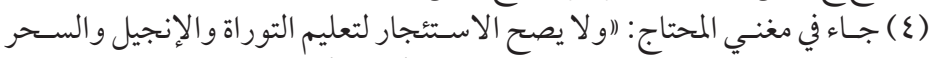

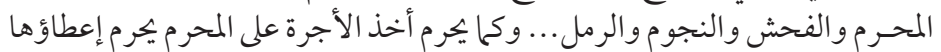

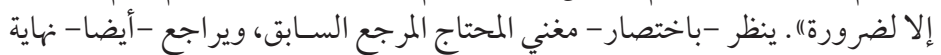

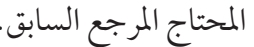

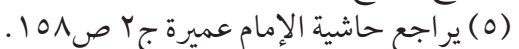

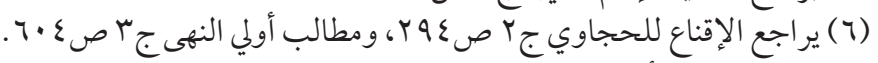

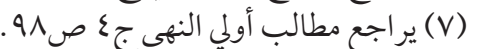

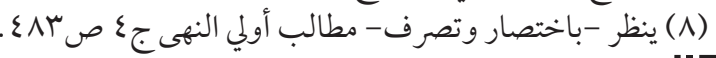

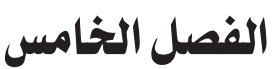

الإجارة على فعل السحر وتعليمه وحله

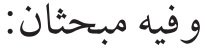

المبحث الأول

الإجارة على فعل السحر وتعليمه

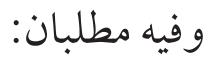

\section{المطلب الأول: - الماري}

\section{حكمم الإجارة على فعل السحر}

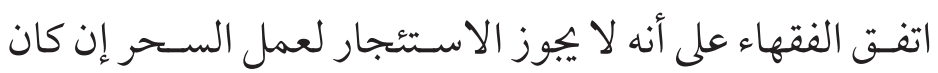

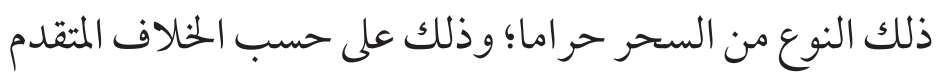

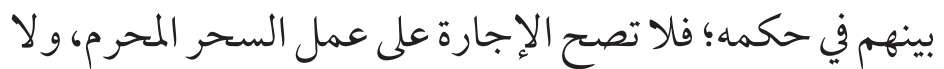

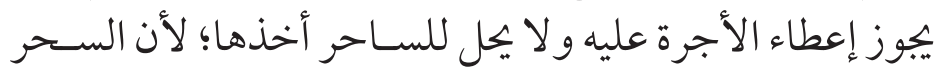
المحرم معصية، ولا يصح الاستئجار على فعل المعصية (1).

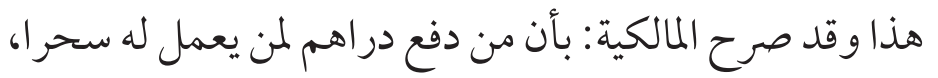

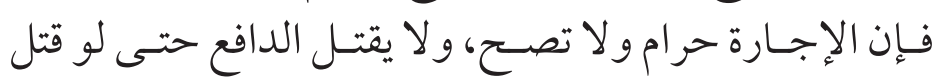

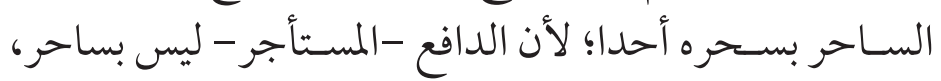

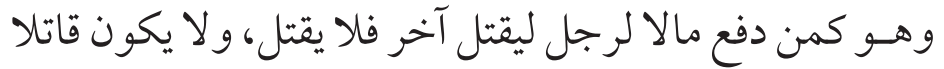

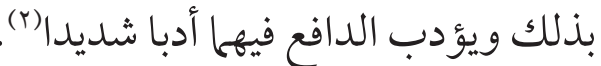

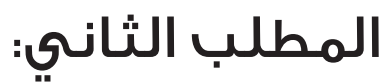

\section{حكم الإجارة على تعليمم السحر}

اختلف الفقهاء في حكم الإجارة على تعليم السحر على رأيين:

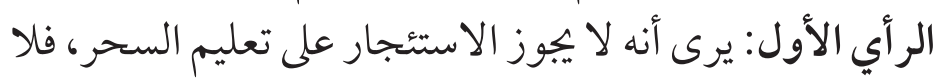

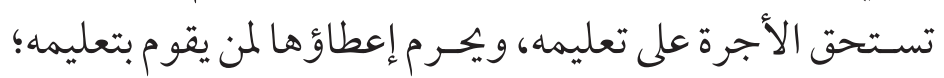

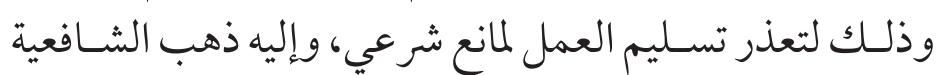
والشيعة الزيدية'(r).

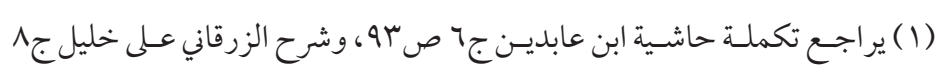

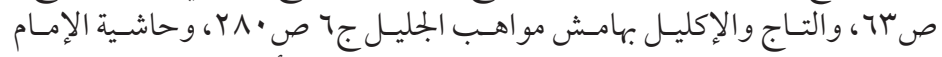

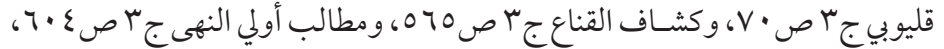

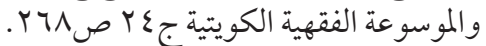

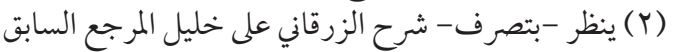

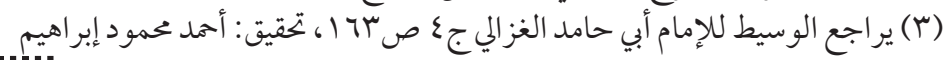


بسحر مثله، وذلك على رأيين:

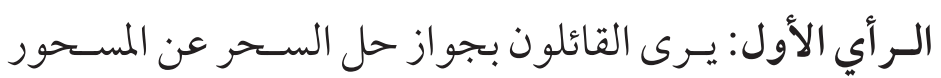

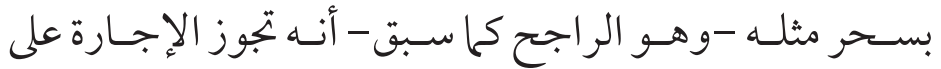

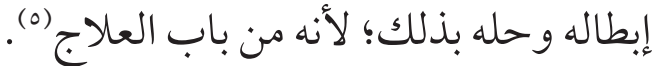

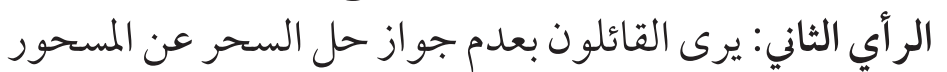

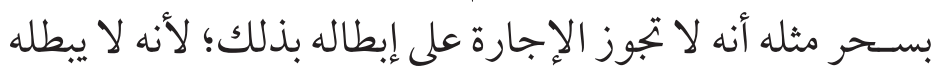

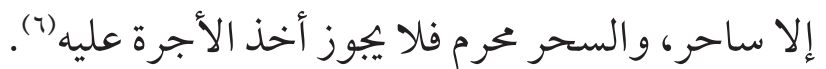

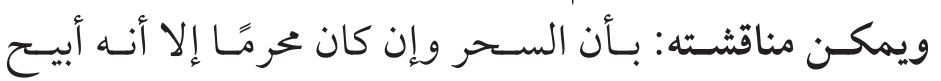

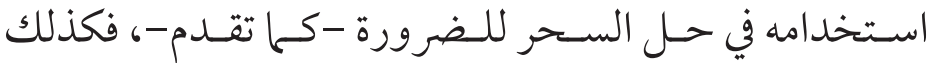
الإجارة على حله بالسحر أبيحت للضرورة الستروة.

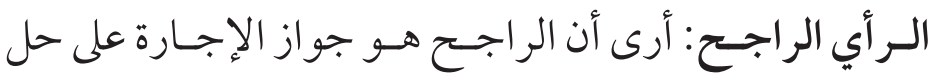

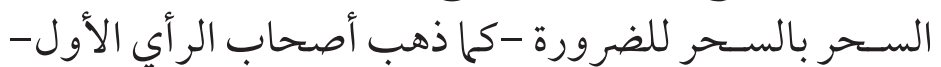

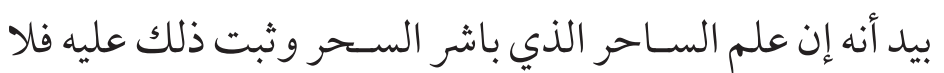
يجيوز له أخذ الأجرة على حله، وعلى ولي الأمر أن يجيره على حله النه

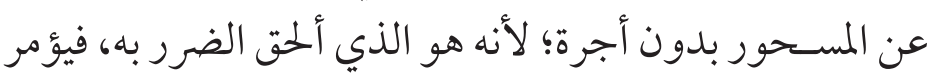

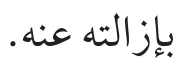
هــذا ما يسره الله تعـالمى لي في هذا البحث، وصلى الله على سـيدنا محمد وعلى آله وصحبه وسلم.

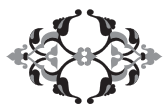

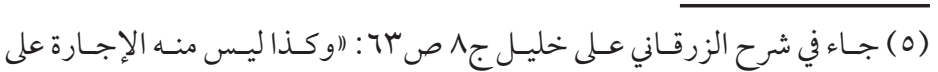

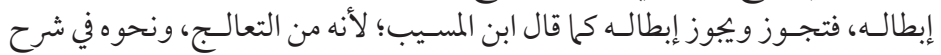

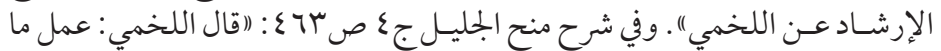

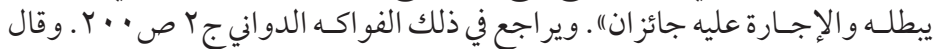

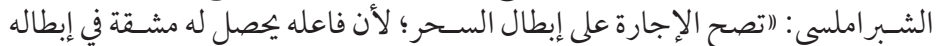

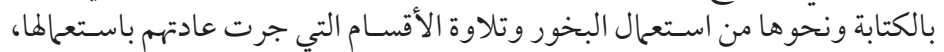

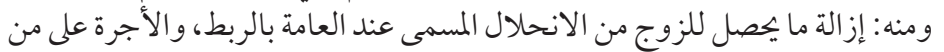

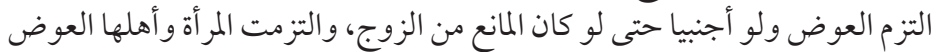

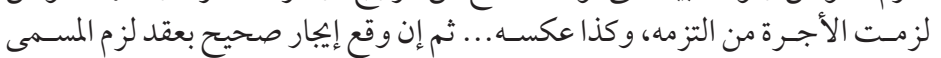

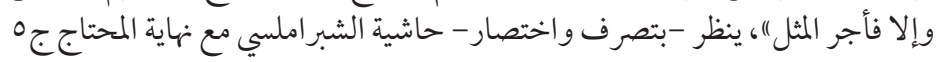
ص.rv

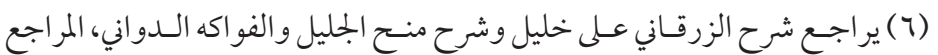

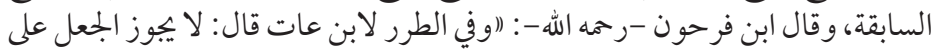

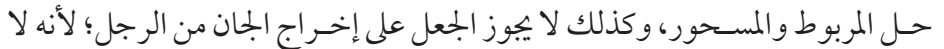

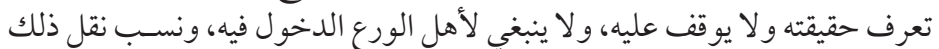

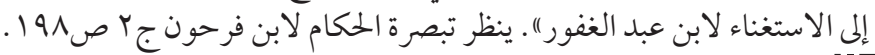

السـابقة، وذلك باتفــاق الفقهـاء(1)، ودليلهم على ذلك السـنة

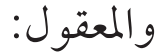

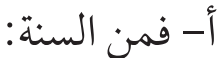

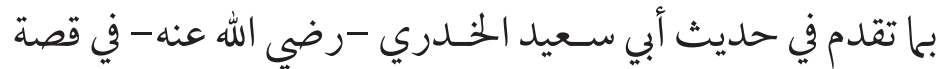

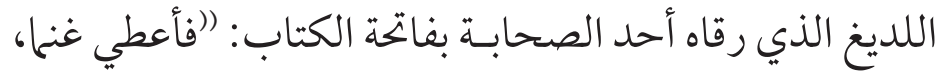

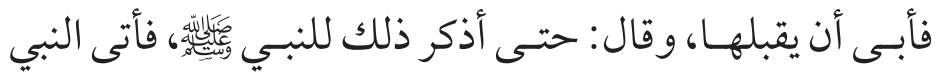

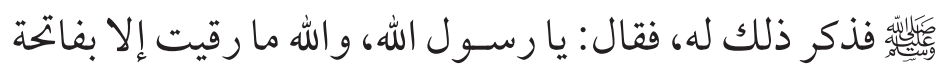

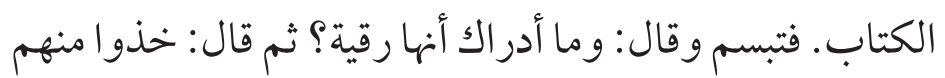

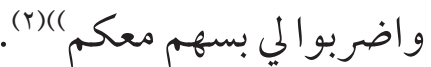

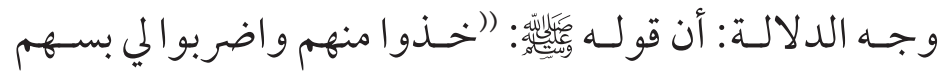
معكم" يــل صر احة على جواز أخذا الأجرة على الرقية بالفاتحة

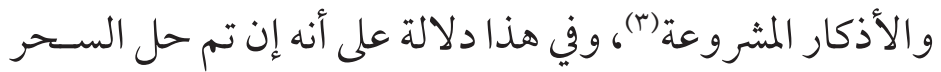
بشيء من ذلك جاز أخذ الأجرة عليه.

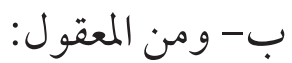

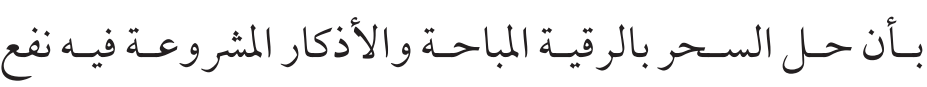

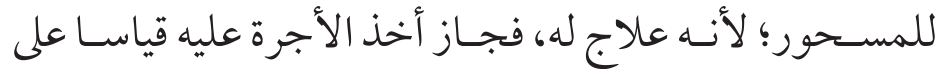

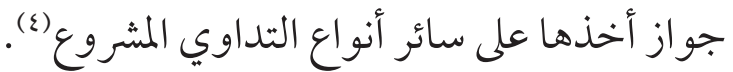

\section{المطلب الثاني حكمم الإجارة علـى حل السحر بسحر مثله عله}

هـل تجوز الإجـارة على حل السـحر بسـحر مثله؟ أقـول وبالله

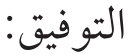

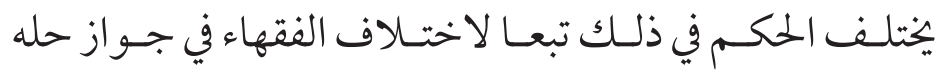

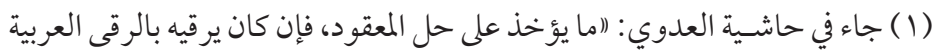

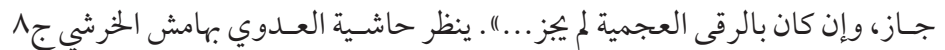

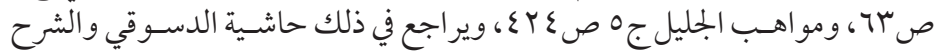

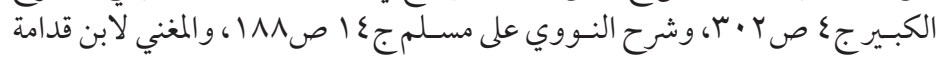

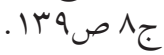

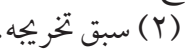

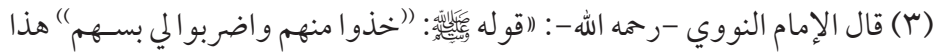

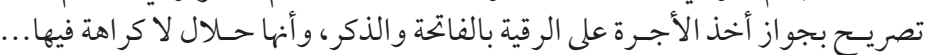

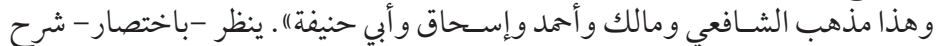

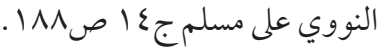

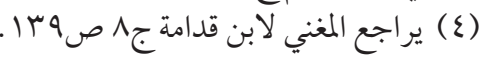




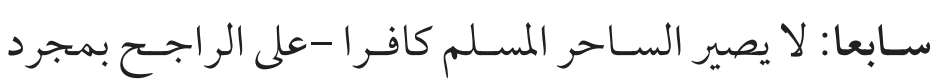

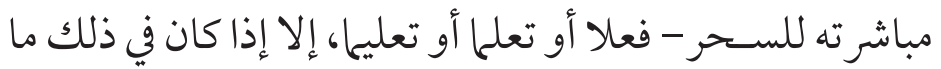
يقتضي الكفر من قول أو فعل أو اعتقاد.

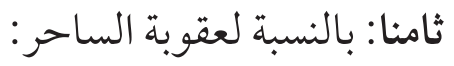

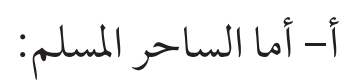
1 - فلا يجيوز قتله ولا يستباح دمه إلا في حالتين: إن كان الكلام المام

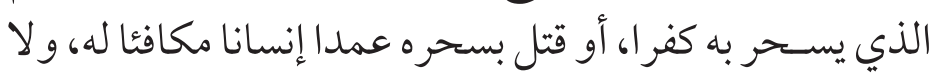

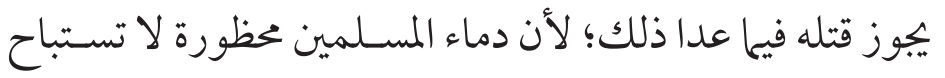
إلا بيقين.

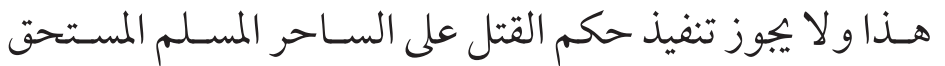

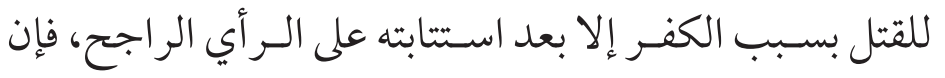

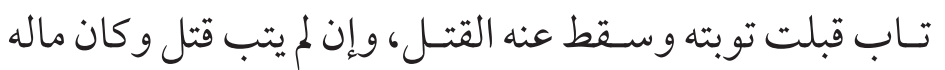

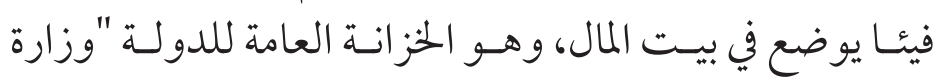

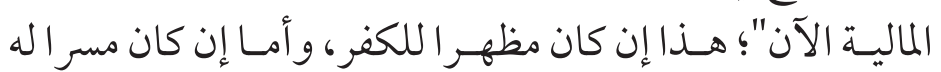

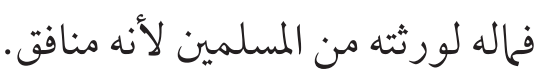

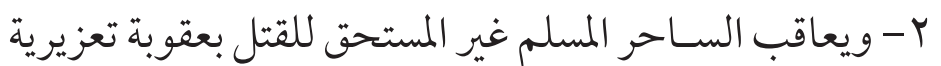

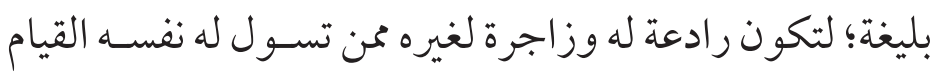

$$
\text { بعمل أسحر مثله. }
$$

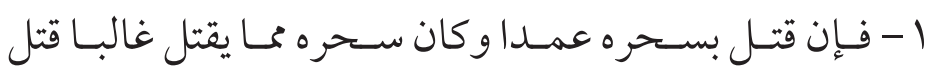
قصاصا؛ سو اء أكان المقتول مسلما أم ذميا.

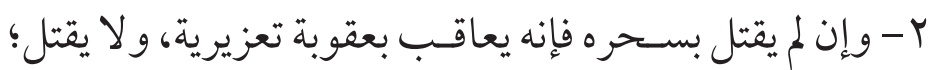

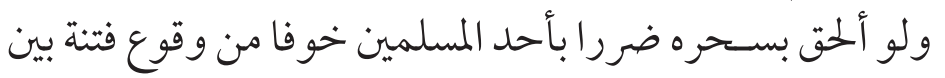
المسلمين وغيرهم من أهل الذهة. تاسعا: حل السحر عن المسحور "النشرة". يتم بإحدى طريقتين: إحداهما: حله بالرقية المباحة والتعوذ المشروع وهو جائز باتفاق الفقهاء.

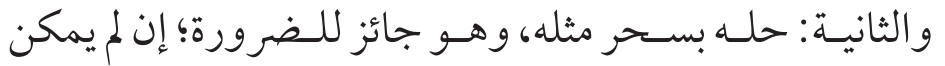

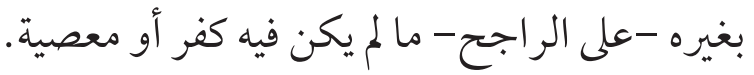
عاشرا: بالنسبة لحكم الإجارة على السحر أو حله:

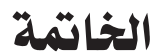

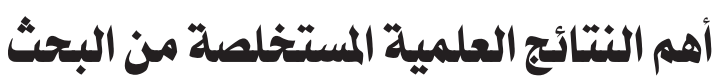

أولا: أن السـحر حرام حرمته شريعة الإسلام وجعلته من كبائر الذنوب؛ لأنه يعرض صاحبه - ما لم يتب - إلى الهلاك بك بعذاب الله الله تعالى في الآخرة، ولما فيه من التعلق بغير الله تعالى اليه

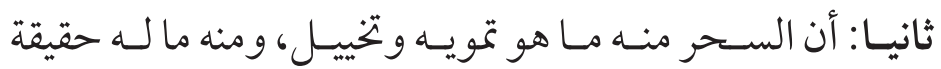

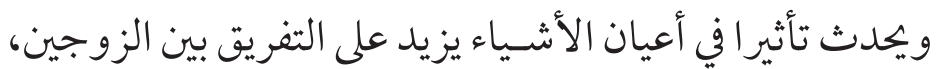
بيد أنه لا يصل تأثيره إلى قلب أعيان الأن أنيان الأشياء.

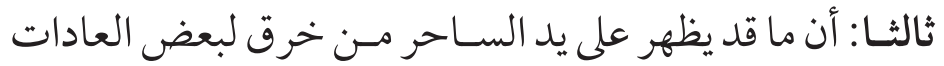

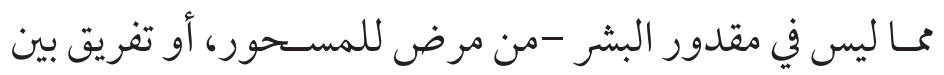

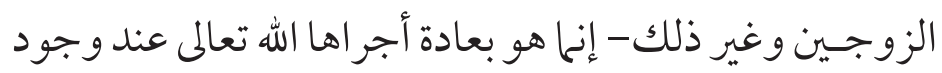

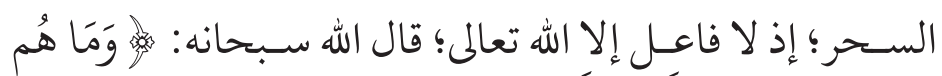

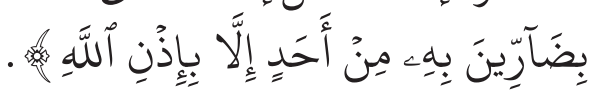

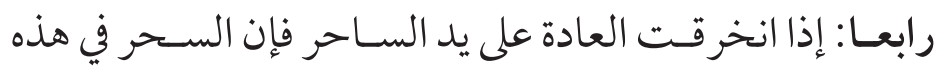

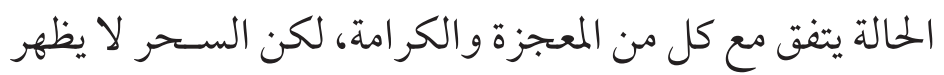

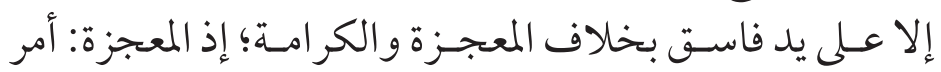

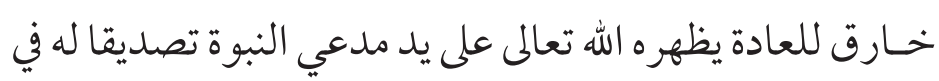

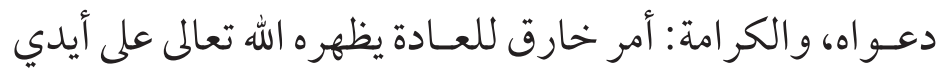

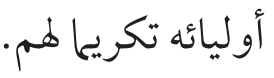
خامسـا: هناك أعمال شبيهة بالسحر حرمها الإسلام؟ كالشعوذة ألساء

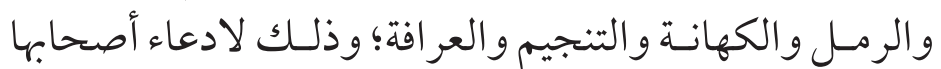

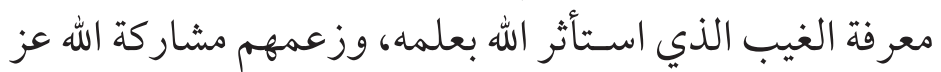
وجل في قدرته والعياذ بالله من ذلك.

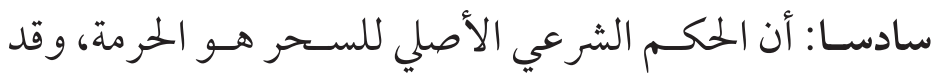

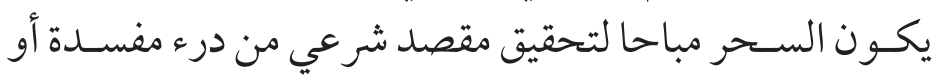

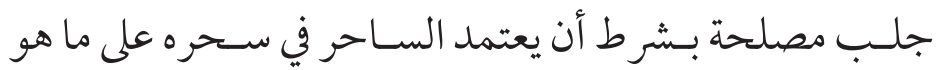

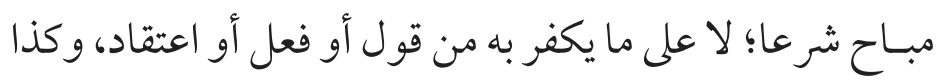

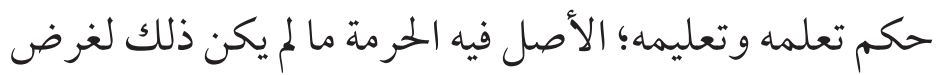

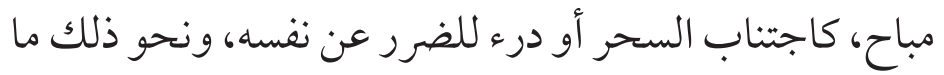
لم يكن في تعلمه كفر أو معصية. 


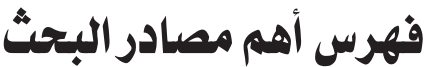

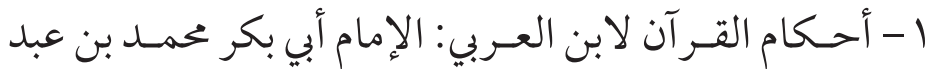

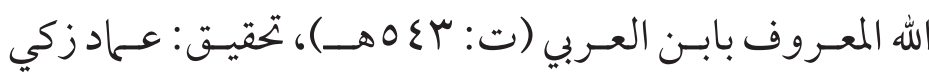
البارودي، ط: المكتبة التوفيقية بالقاهرة.

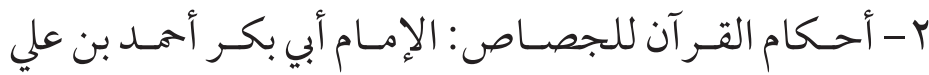

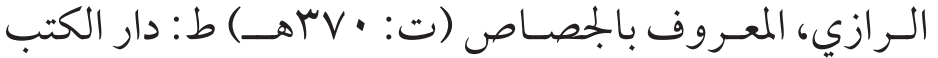

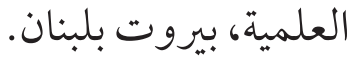

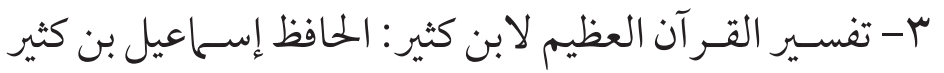

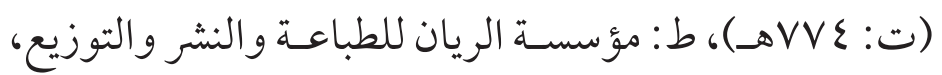

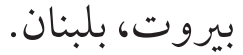
ع - الجامع لأحكام القر آن للقرطبي: الإمام أبي عبد الله محمد بن

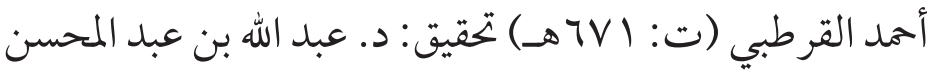
التركي، ط: مؤسسة الرسالة، بيروت بلبنان.

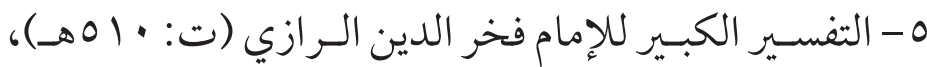

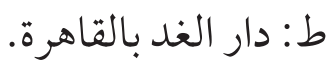

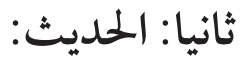

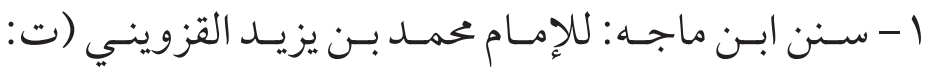
لrVo

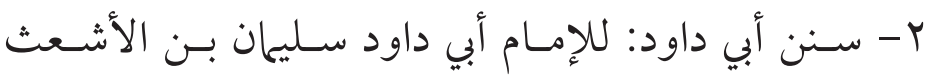

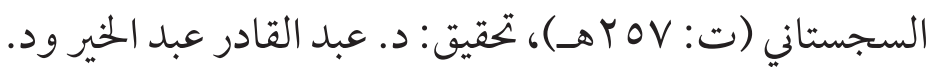

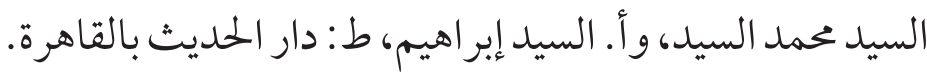

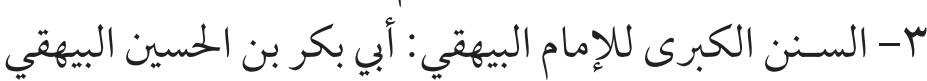
(ت: ع01 \&هـ)، الناشر: دار الكتاب الإسلامي بالقاهرة.

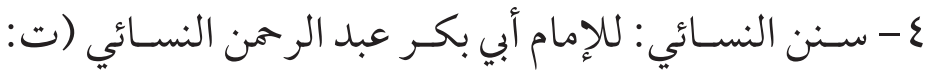

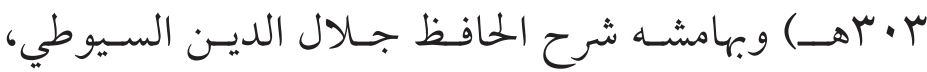
وحاشية السندي، ط: المكتبة العلمية، بيروت بلبنانيان.

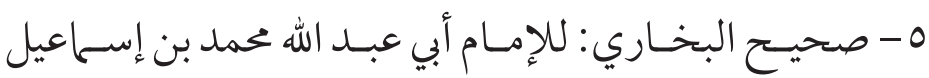

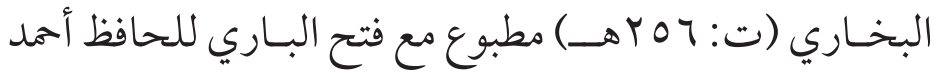

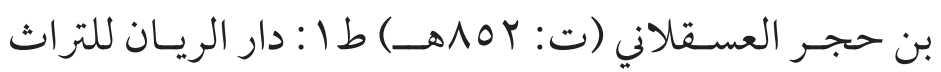

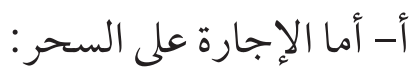
فتجوز الإجارة على فعله إن كان السحر مباحا، ولا تجوز إن كان

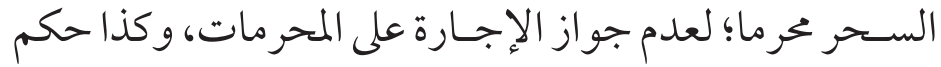
الإجارة على تعلمه وتعليمه.

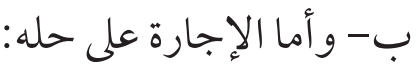

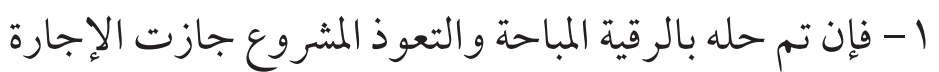

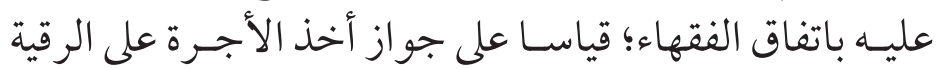
المباحة.

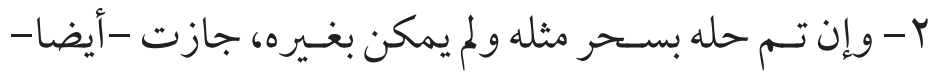
الإجارة عليه -على الراجح- للضرورة التي تقتضي ذلك.

تمت بحمد الله تعالى

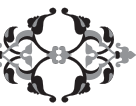


الزيلعي (ت: الرع Vهـ) و وبهامشـه حاشـية الشلبي على شرح كنز

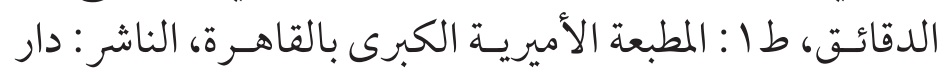

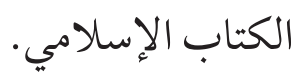

ع - حاشية ابن عابدين: للعلامة محمد أمين الشهير بابن عابدين

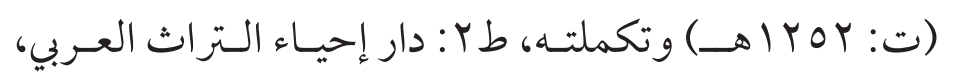

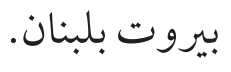

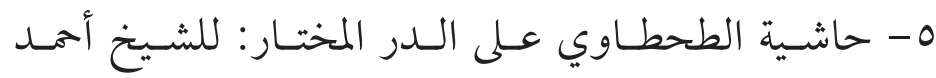

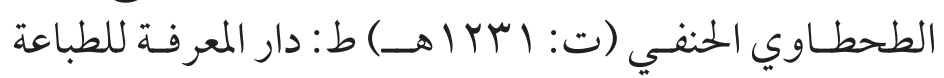
و النشر، بيروت بلبنان. ج - شرح فتـح القدير على الهداية لابن الهمام: الإمام كحال الدين

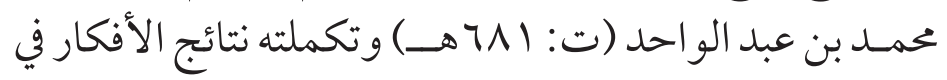

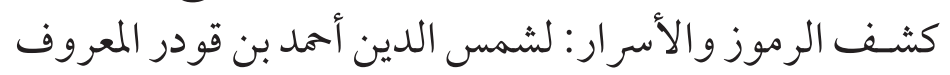

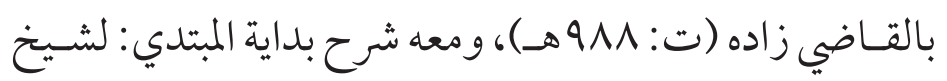

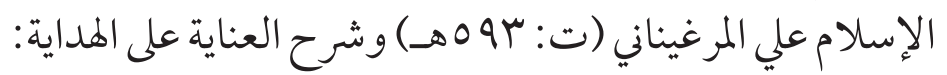

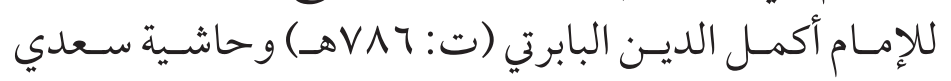

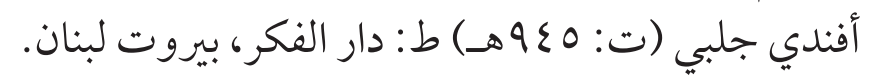

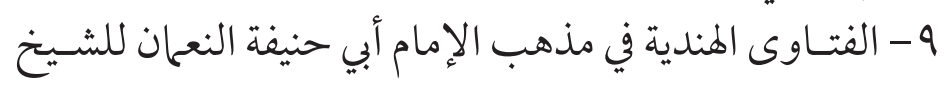

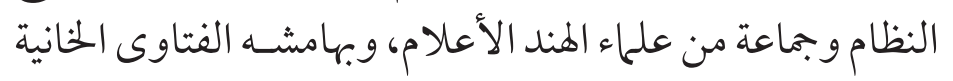

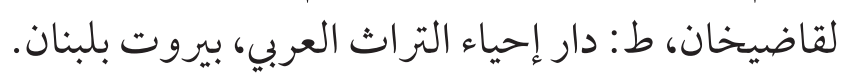

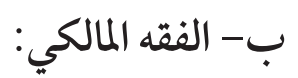

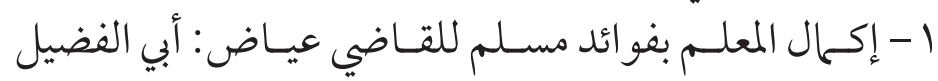

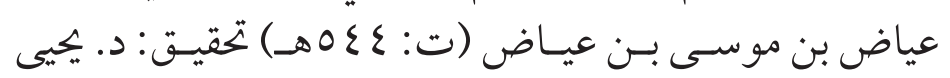
إسماعيل، ط ا : دار الوفاء بالمنصورة.

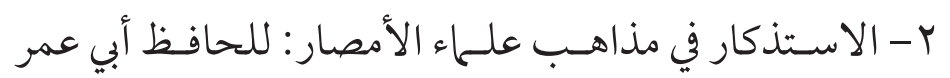

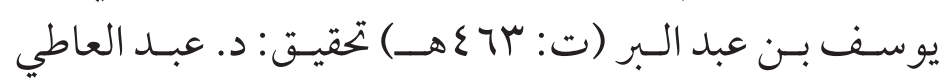

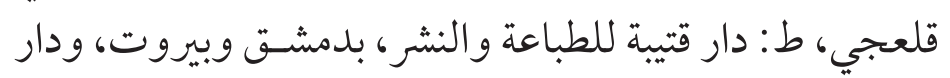
الوعي بحلب و القاهرة، توزيع مؤسسة الرسالة.

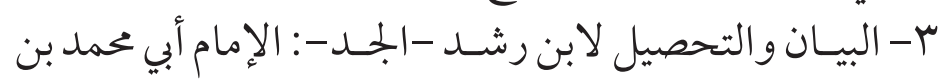

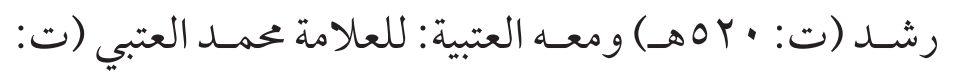

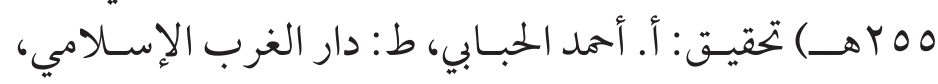
بيروت بلبنان.
بالقاهرة.

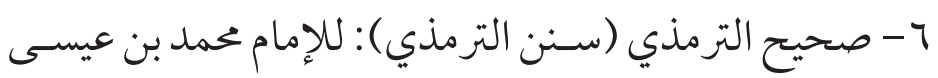

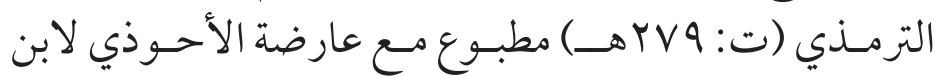

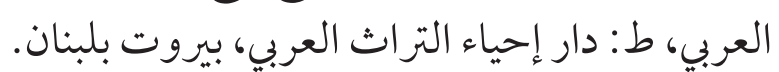

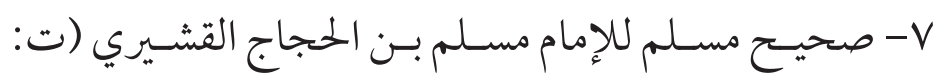

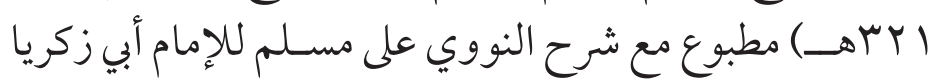

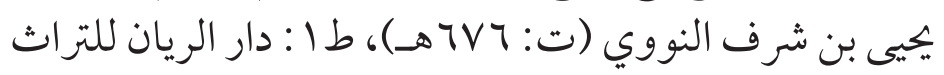
بالقاهرة.

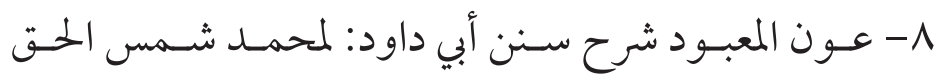

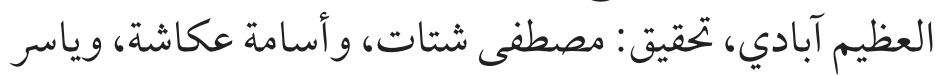
أبو شادي، ط: المكتبة التوفيقية بالقاهرة.

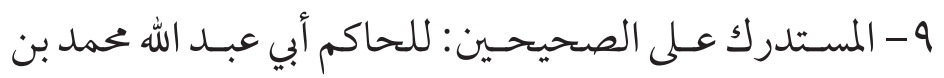

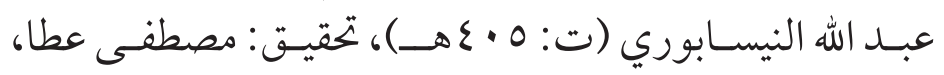
ط ا : دار الكتب العلمية، بيروت بلبن البنان.

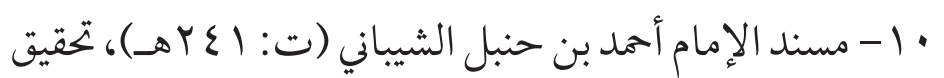

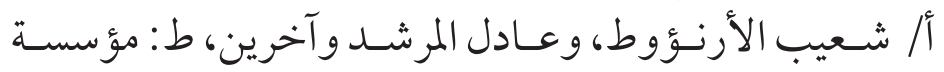
الرسالة بيروت بلبنان.

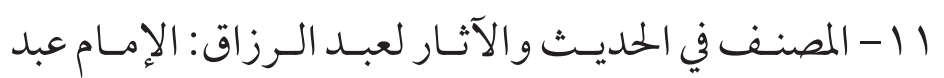

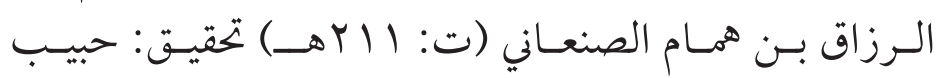

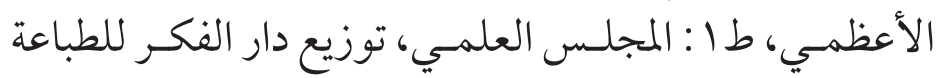
والنشر بالقاهرة.

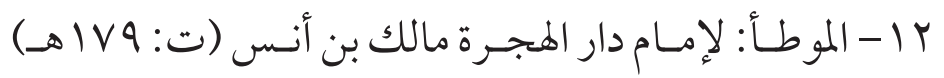

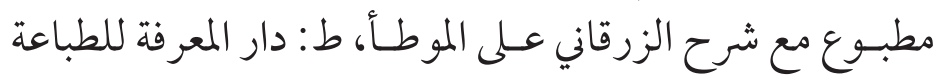
والنشر، بيروت بلبنان. ثالثا: الفقه: أ أ- الفقه الحنفي: الفقه:

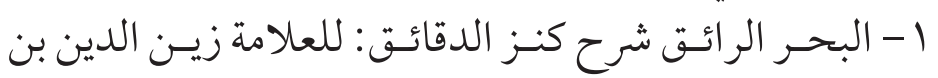

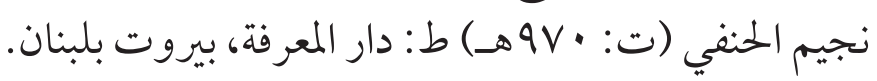

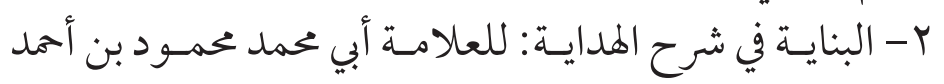
العيني (ت: 100هـ) ط طب: مصطفى البابي الحلبي القاهرة.

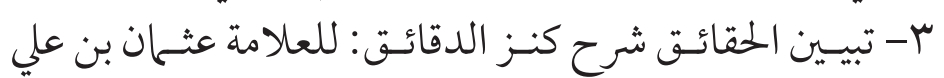


الإمـام أبي بكـــ محمــد بن عبـــ الله المعـروف بابن العـربي (ت:

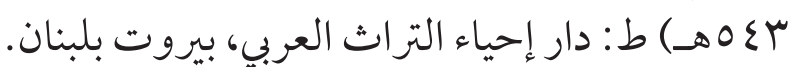

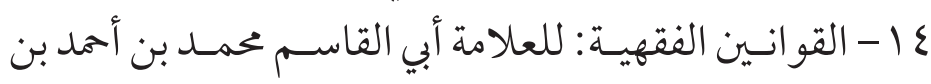
جزي (المتوفى: اعلهـ)، ط ا : عالم الفكر بالقاهرة.

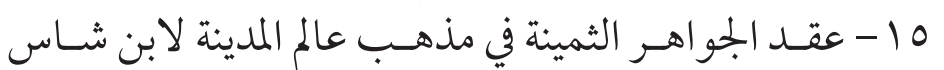

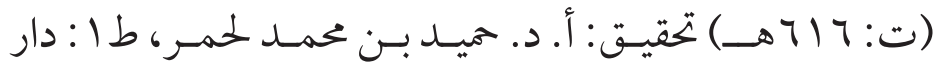
الغرب الإسلامي، بيروت بلبنان.

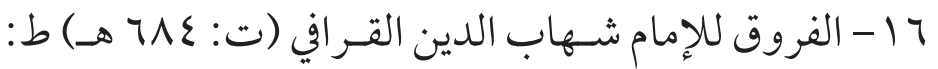

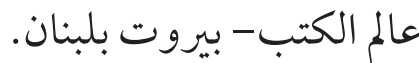

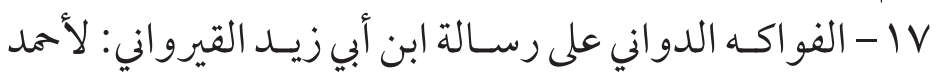

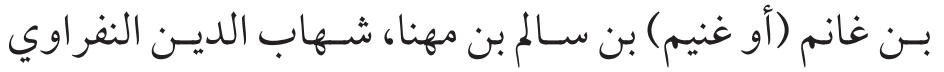

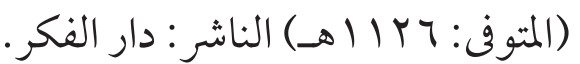

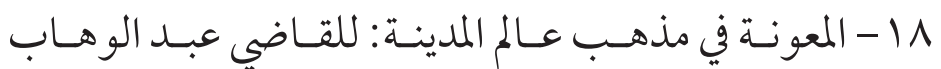

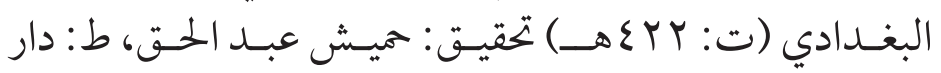

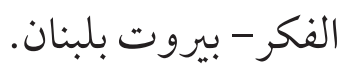

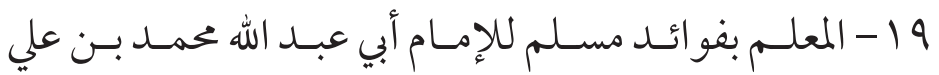

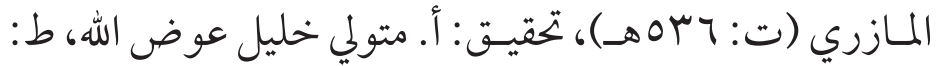
المجلس الأعلى للشؤون الإسلامية بالقاهرة.

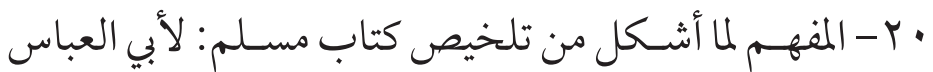

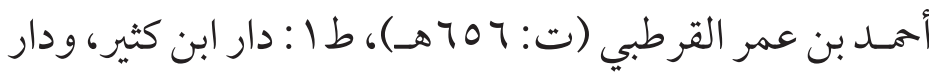

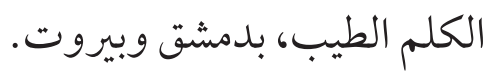

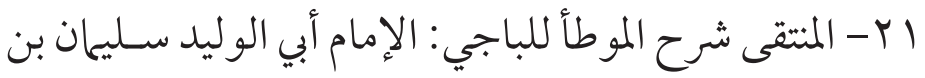
خلف الباجي (ت: ع9 عهـ)، ط: مطبعة السعادة بالقاهرة.

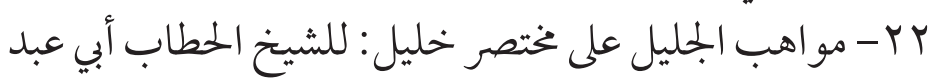

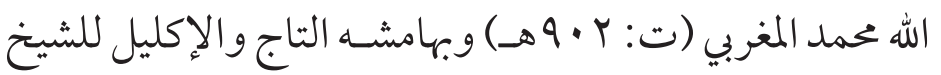

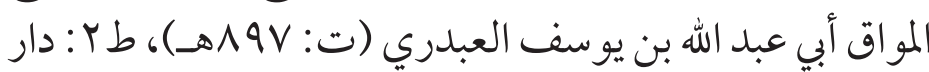

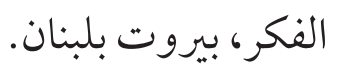
بَ - النو ادر و الزيادات على ما في المدونة وغيرهان من الأمهات:

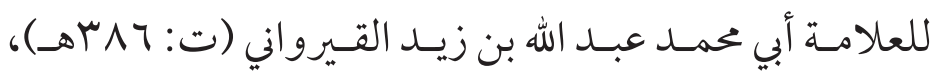
تحقيق د. محمد حجي ط: دار الغرب الإسلامي، بيروت بلبر بلبنان.
ع - التمهيد لما في المو طأ من المعاني والأسـانيد: للحافظ أبي عمر

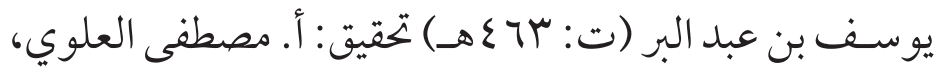

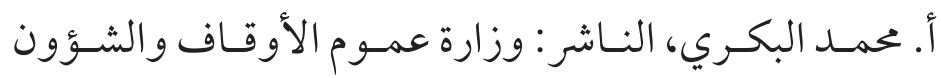

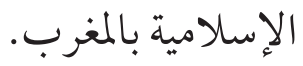

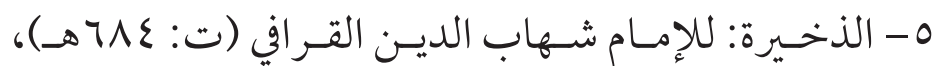

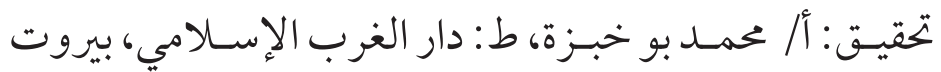
بلبنان. 7 - تبصرة الحكام في أصـول الأقضية ومناهج الحكام: للعلامة إبر اهيـم بن محمــد بن فرحسون (ت:

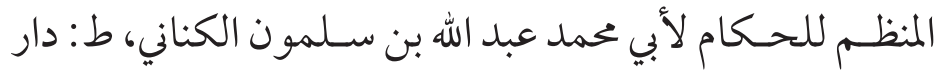
الكتب العلمية بيروت بلبنان.

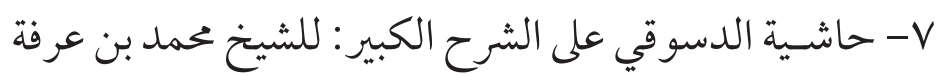

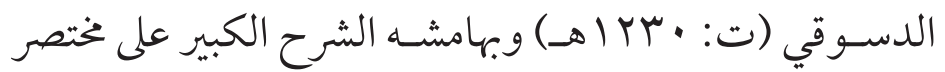

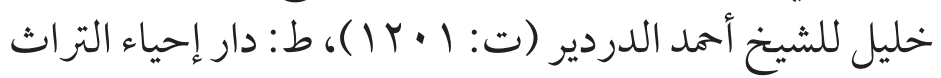
العربي، عيسى الحلبي، بالقاهرة. 1- الخرشي على خختصر خليل : للشيخ محمد بن عبد الشبد الله الخرشي

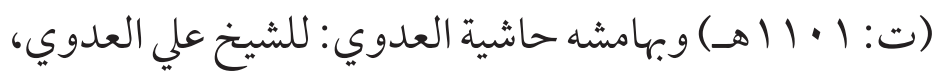
ط: دار الفكر للطباعة والنشر بيروت بلبنان.

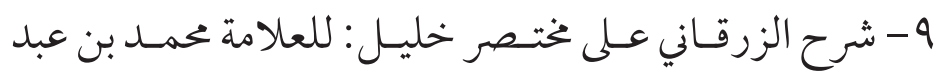

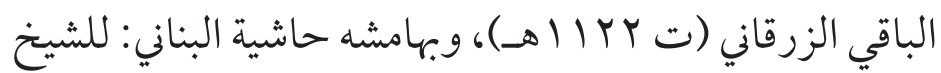
محمد البناني، ط: دار الفكر، بيروت بلبنانينان.

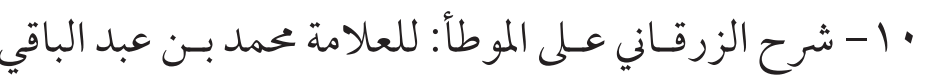

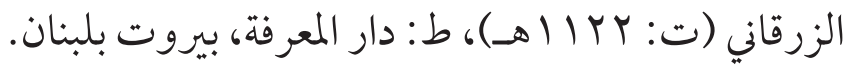

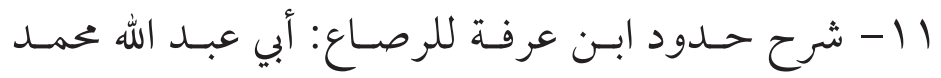

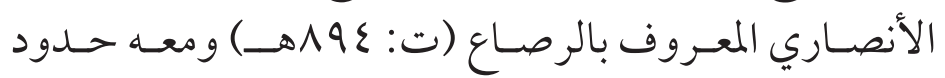

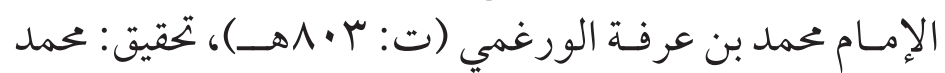

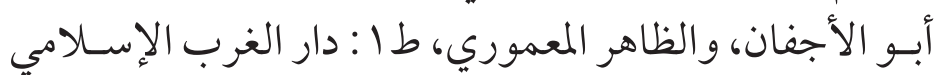

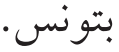
r ا - شرح منـح الجليل على نختصر خليل : للشـيخ محمد عليش (ت: 99 Y 1 1هـ) ط: مكتبة النجاح، طر ابلس بليبيا. با - عارضـة الأحوذي بشرح صحيح الترمـــي لابن العربي: 
محمد بن أحــــ الشربيني المعروف بالخطيـب (ت: 9VVهـ) ط: دار الفكر.

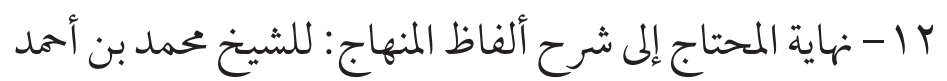

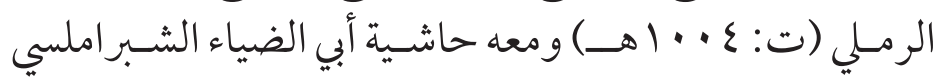

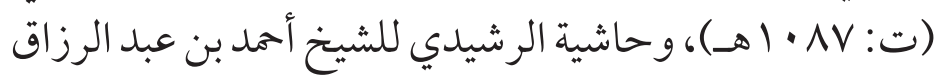

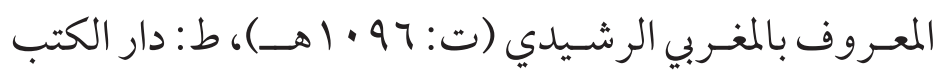
العلمية، بيروت بلبنان.

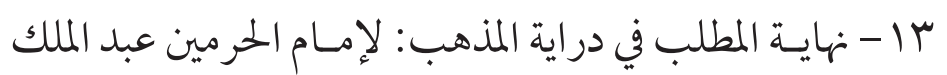

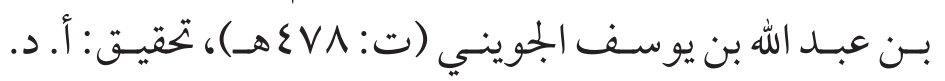

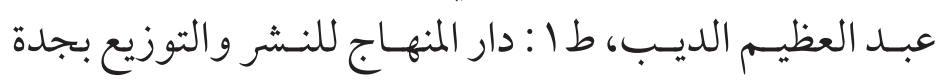

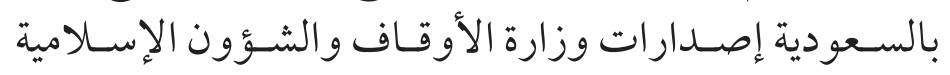

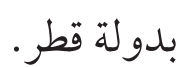

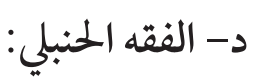

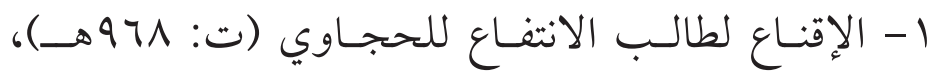

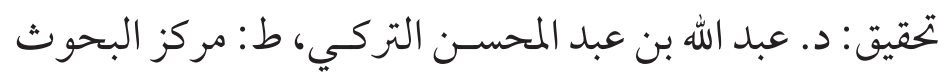

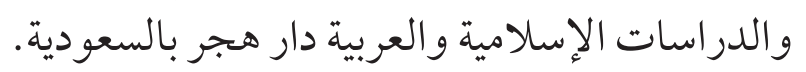

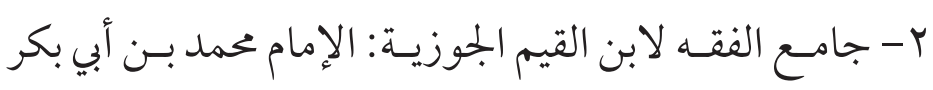

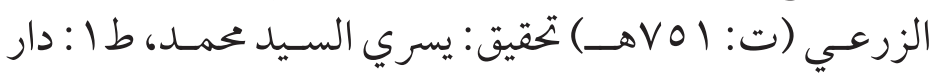

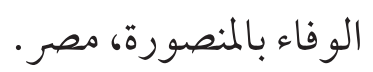
بـ شرح منتهى الإرادات: للشـيخ منصـور البهـوتي (ت:

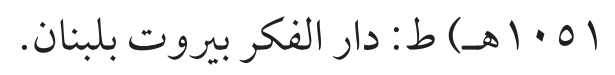

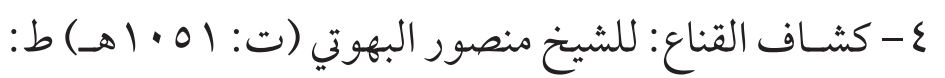
دار الفكر بيروت بلبنان.

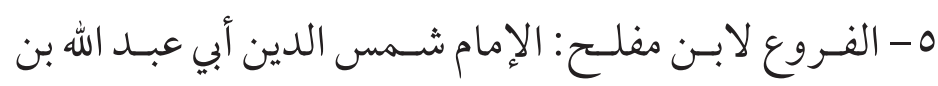

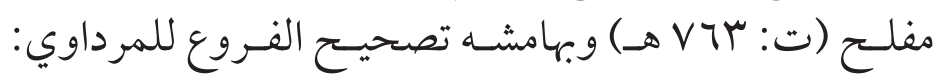

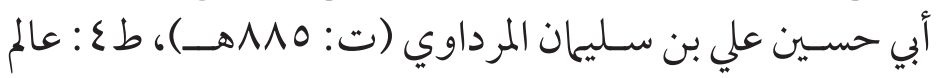
الكتب- بيروت بلبنان.

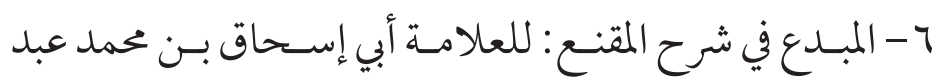

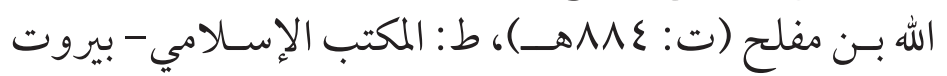
بلبنان. V المحــرر في الفقـهـ عـلى مذهب الإمـام أحمد بن حنبل لشـيخ

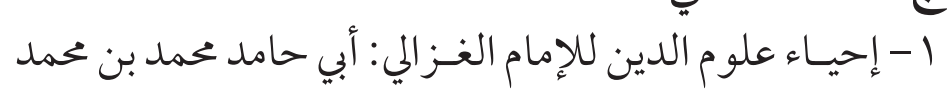

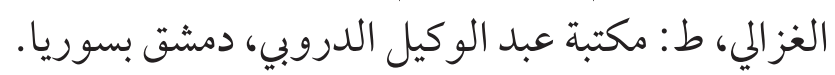

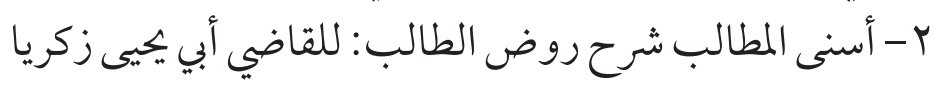

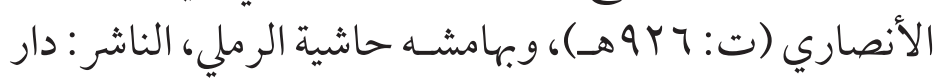

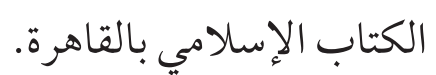

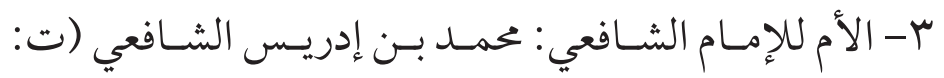

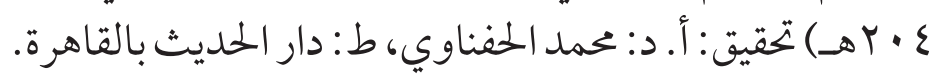

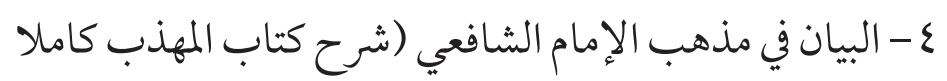

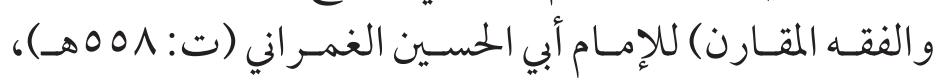

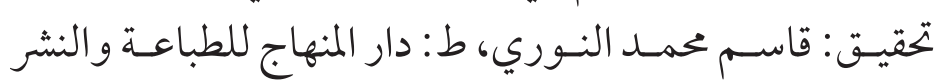
والتوزيع. 0 - المجمـوع شرح المهذب: للإمـام أبي زكريا محيي الدين يميى

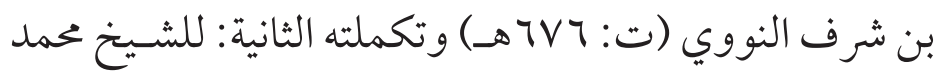

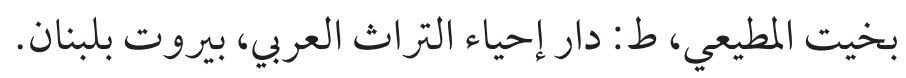

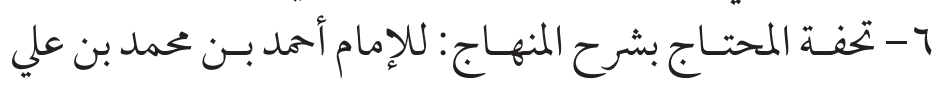

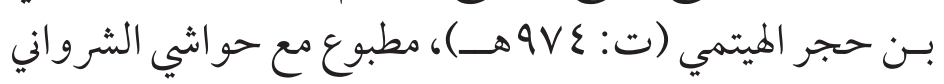

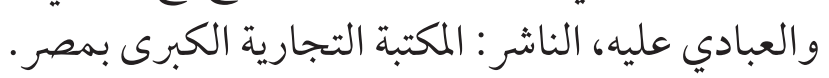

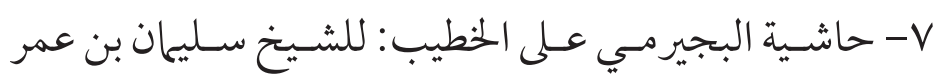

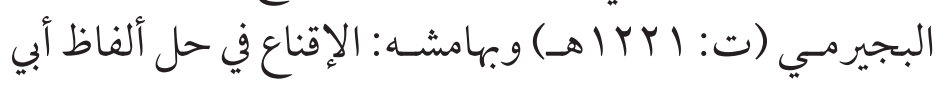

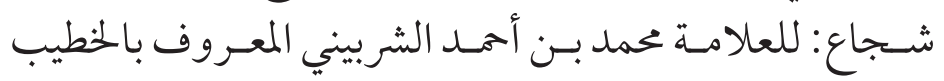

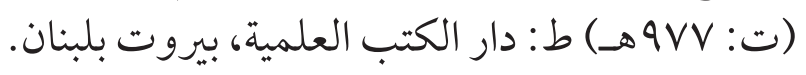

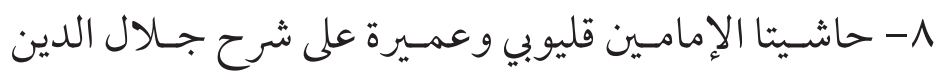

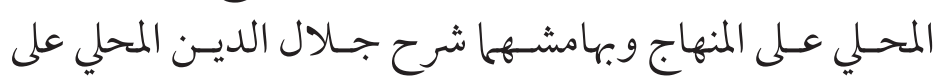
هنهاج الطالبين، ط: دار أخبار الخبار اليوم بالقاهرة.

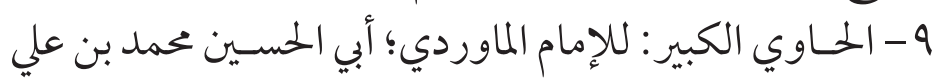

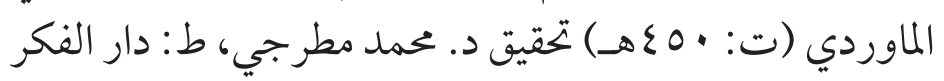
لمباعة بيروت بلبنان.

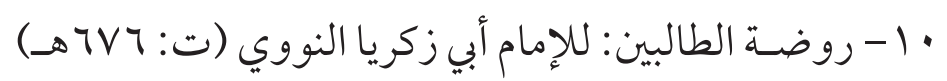

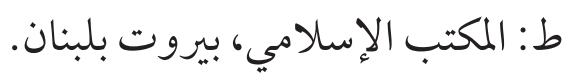
11 - مغني المحتـاج إلى معرفة ألفاظ المنهاج للخطيب: العلامة 
r - الصحــاح للجوهري: العلامة إسـاعيل بـن حماد الجوهري (ت: سوسهـ)، ط: دار العلم للمالايين، بيروت بلبنان.

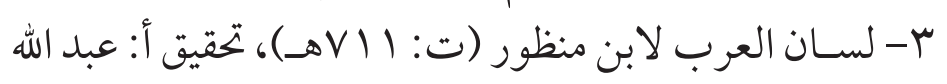

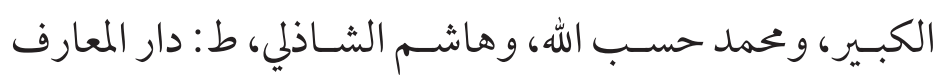
بالقاهرة.

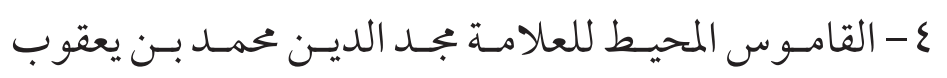
الفيروزآبادي (ت: V V Vهـ) ط: دار الجيل، بيروت بلبنان.

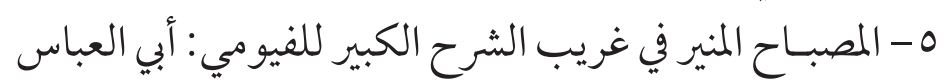

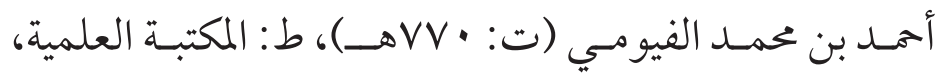
بيروت بلبنان.

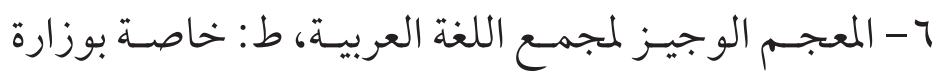

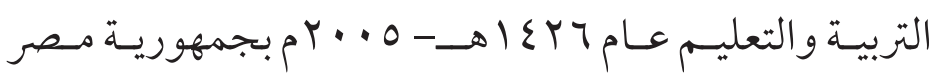

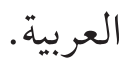

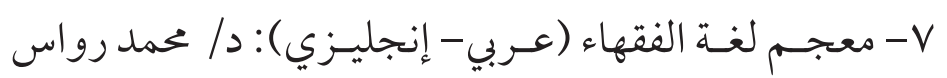

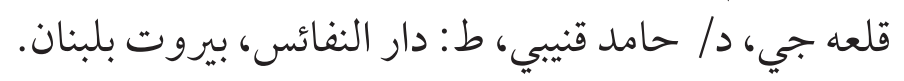

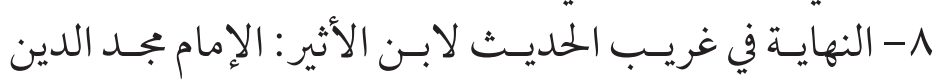

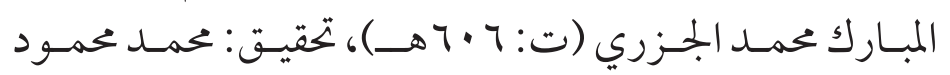

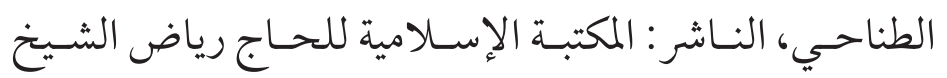
بالقاهرة.

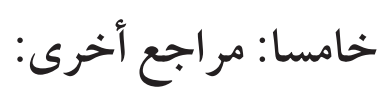

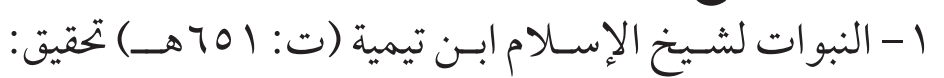

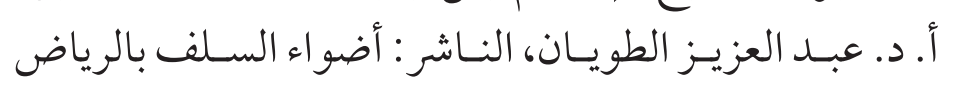

$$
\text { السعودية. (عقيدة). }
$$

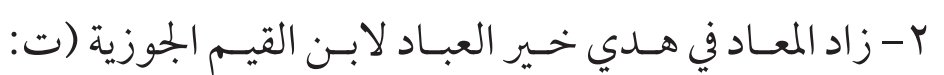
Vه OVI)، الناشر: دار عمر بن الخطاب بالإسكندرية. (سيرة).

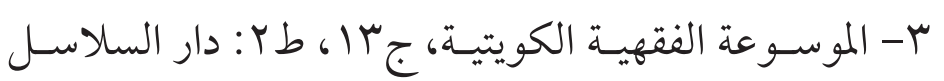

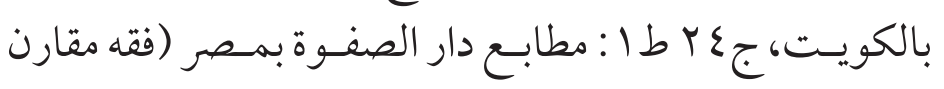

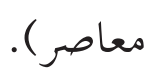

الإسـلام ابن تيمية مجد الدين عبد السـلام بن عبد الله ابن تيمية

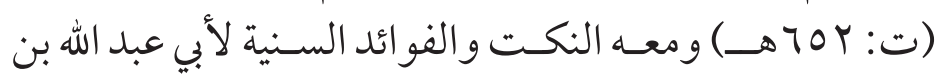

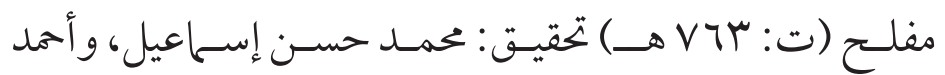
محروس صالح، ط: دار الكتب العلمية- بيروت بلبنان.

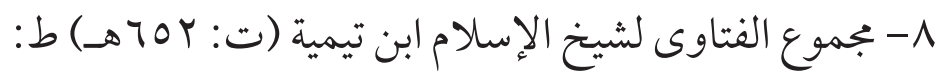
بمع الملك فهد لطباعة المصحف الشريف بالسعودية.

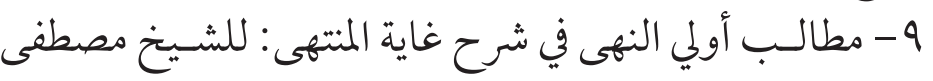

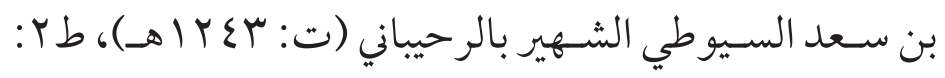

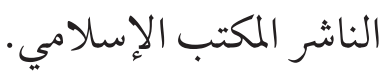

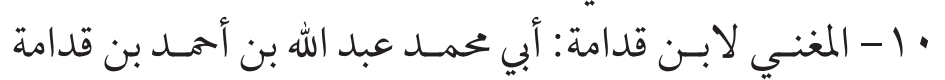

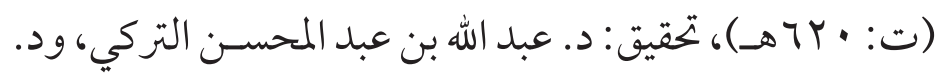

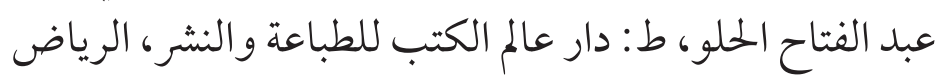
بالمملكة العربية السعودية.

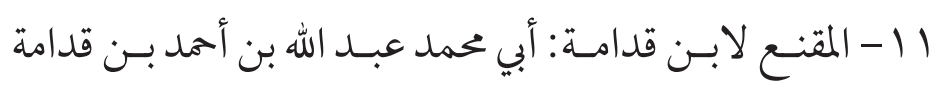

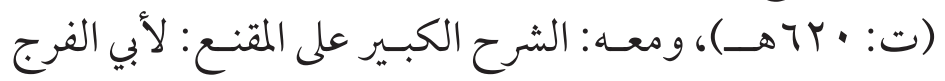

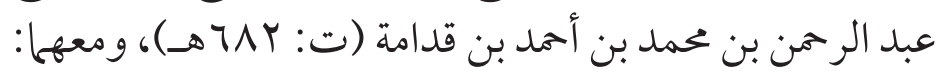

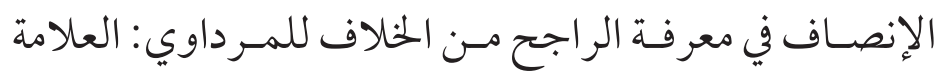

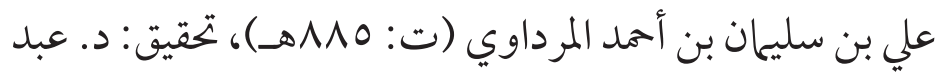

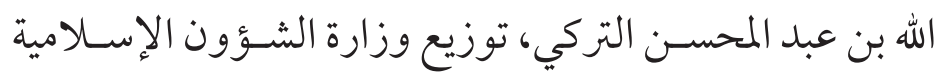
و الأوقاف والدعوة والإرشاد بالمملكة العربية السعودية.

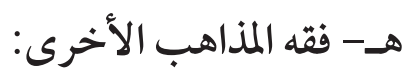

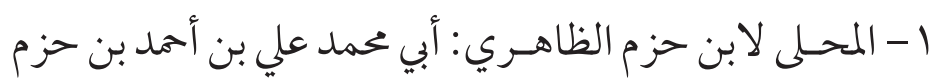

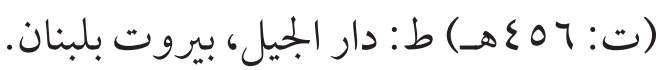

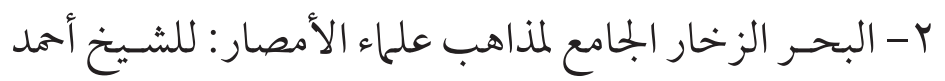

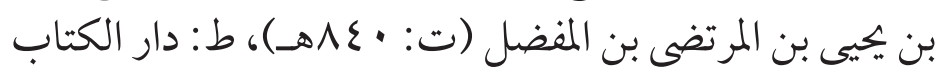
الإسلامي بالقاهرة. ب- المبسـوط في فقه الإمامية: لأبي جعفر الطوسي، تعليق: محمد الباقر، توزيع: دار الكتاب الإسلامي، بيروت بلبنإنان. رابعا- المعاجم اللغوية:

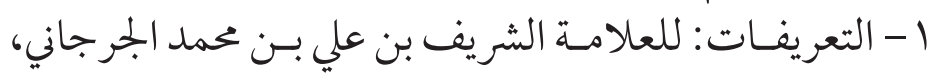

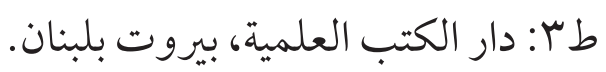


المطلب الثاني: بعض النشرة النافعة في علاج السحر ... V7

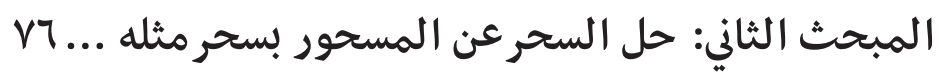

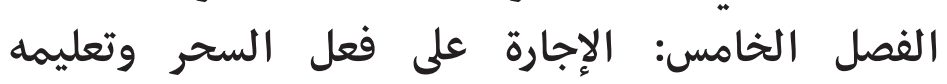

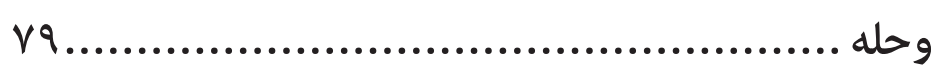
المبحث الأول: الإجارة على فعل السحر وتعليمه .......

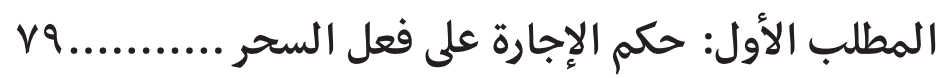

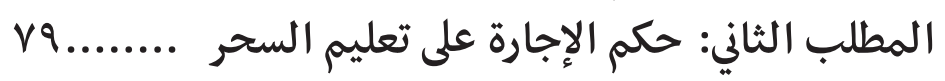

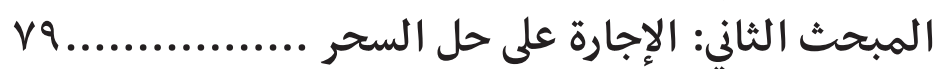
المطلب الأول: حكم الإجارة على حل الإجارة السحر الى بالرقية

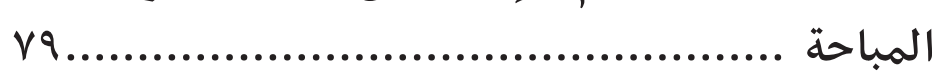
المطلب الثاني: حكم الإجارة على حل السحر بسحر مثله •

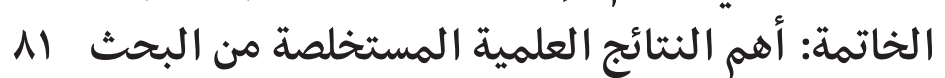
فهرس أهم مصادر البحث......................................... $\Lambda \mathrm{V}$ فهرس الموضوعات .

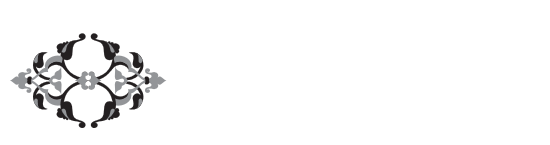

\section{فهرس الموضوعات}

$\varepsilon r$ المقلدة

$\varepsilon \varepsilon$ التمبيد المعله

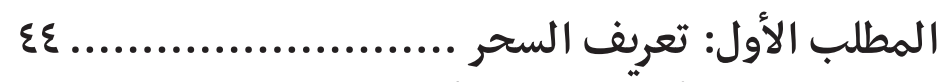
المطلب الثاني: أنواع السحر (أقسامه) ......................

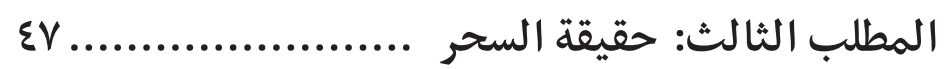
المطلب الرابع: ملى تأثير السحر في أعيان الأشياء ..... •.

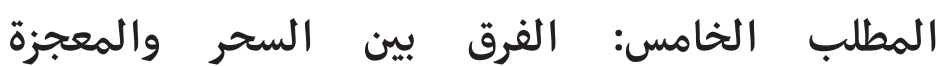

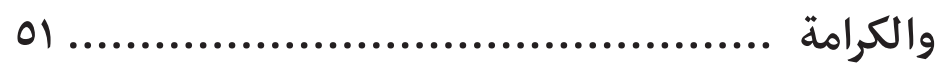
المطلب السادس: الألفاظ ذات الصلة بالسحر ......... الفصل الأول: الحكم الشرعي للسحر .......................... المبحث الأول: الحكم الشرعي لفعل السحر ............... المطلب الأول: الحكم الأصلي لفعل السحر ............... المطلب الثاني: الأحكام الأخرى التملي تعرض لفعل الإل ov. السحر المعلr

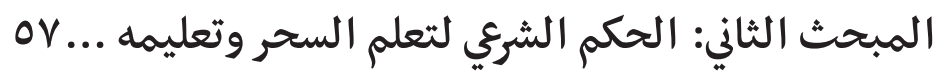

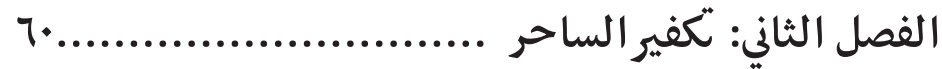
$7 \varepsilon$ الفصل الثالث: عقوبة الساحر . .

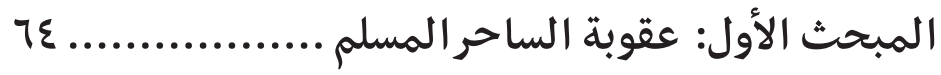

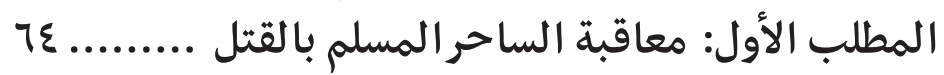
المطلب الثاني: هل يشترط لمعاقبة الساحر المسلم بالقتل $7 \mathrm{~V}$ استتابة الساحر؟ المطلب الثالث: ميراث الساحر إذا قتل .................

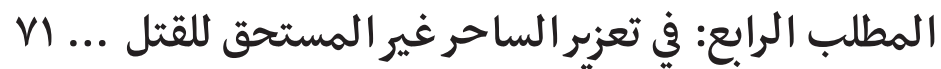

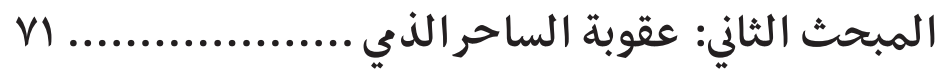
الفصل الرابع: حل السحر عن المسحور (النشرة) ......... التمهيل: في تعريف النشرة ودليل مشروعيتها ل...........

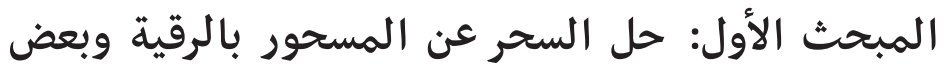
VE.

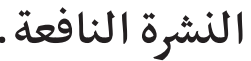

المطلب الأول: حكم حل السحر عن المسحور بالرقية . Vع 